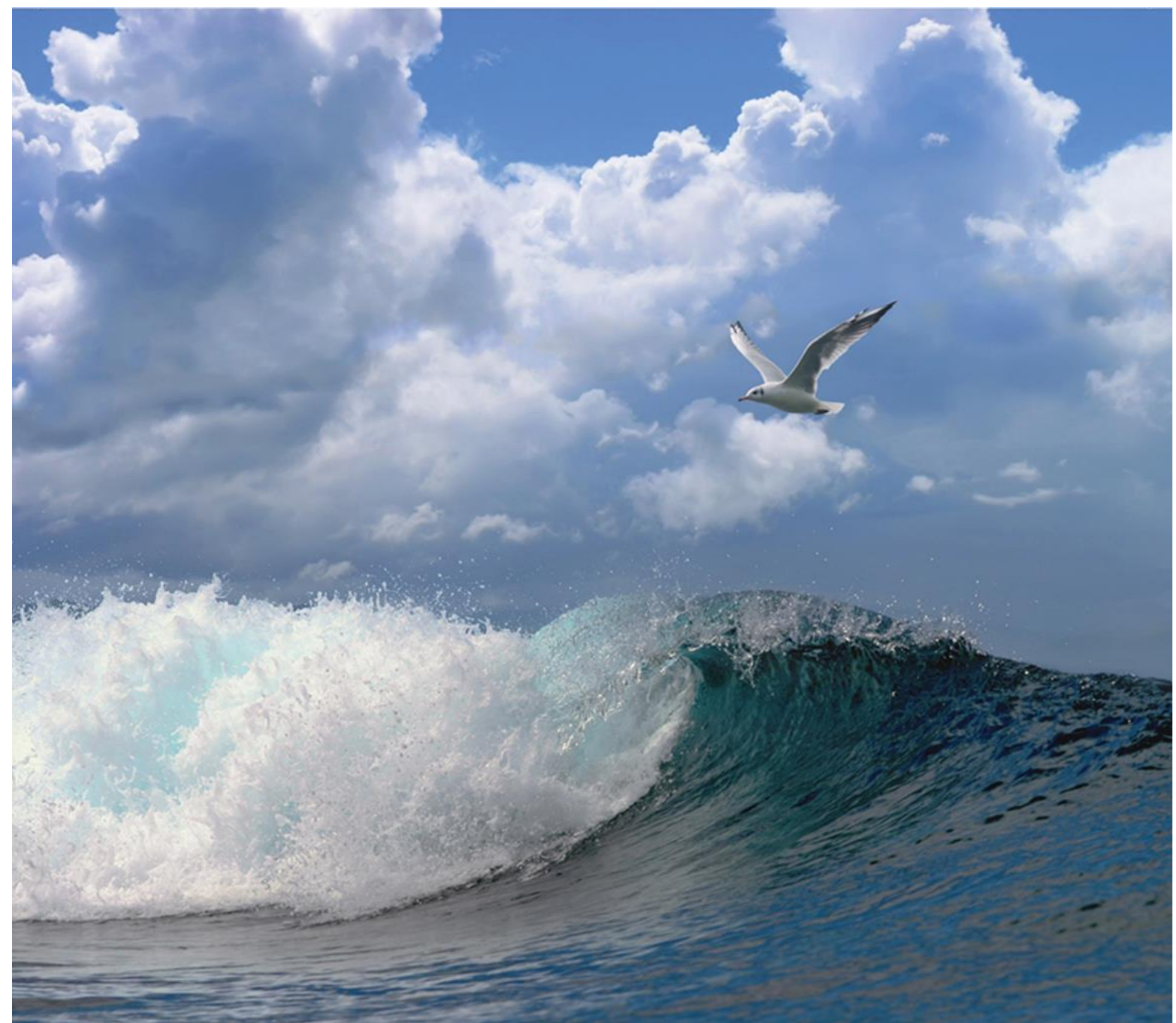

\title{
Visecologie in de vooroever
}




\section{Visecologie in de vooroever}

Auteur(s): Ralf van Hal, Joey Volwater, Floor Soudijn, Ingrid Tulp

Wageningen Marine Research

IJmuiden, oktober 2021

VERTROUWELIJK Nee

Wageningen Marine Research rapport C077/21 
Keywords: Zandsuppleties, visecologie, kustzone, veldwerk

Opdrachtgever: RWS-WVL, hoogwaterveiligheid

T.a.v.: Petra Damsma

Postbus 17

8200 AA Lelystad

Dit rapport is gratis te downloaden van https://doi.org/10.18174/555130

Wageningen Marine Research verstrekt geen gedrukte exemplaren van rapporten.

Wageningen Marine Research is ISO 9001:2015 gecertificeerd.

(c) Wageningen Marine Research

Wageningen Marine Research, instituut binnen de rechtspersoon Stichting Wageningen Research, hierbij vertegenwoordigd door Drs.ir. M.T. van Manen, directeur bedrijfsvoering

KvK nr. 09098104, WMR BTW nr. NL 8113.83.696.B16. Code BIC/SWIFT address: RABONL2U IBAN code: NL 73 RABO 0373599285
Wageningen Marine Research aanvaardt geen aansprakelijkheid voor gevolgschade, noch voor schade welke voortvloeit uit toepassingen van de resultaten van werkzaamheden of andere gegevens verkregen van Wageningen Marine Research. Opdrachtgever vrijwaart Wageningen Marine Research van aanspraken van derden in verband met deze toepassing.

Alle rechten voorbehouden. Niets uit deze uitgave mag weergegeven en/of gepubliceerd worden, gefotokopieerd of op enige andere manier gebruikt worden zonder schriftelijke toestemming van de uitgever of auteur.

A_4_3_1 V31 (2021) 


\section{Inhoud}

$\begin{array}{lr}\text { Samenvatting } & 5\end{array}$

$\begin{array}{lr}\text { Begrippenlijst } & 10\end{array}$

$1 \quad$ Inleiding $r$

1.1 Achtergrond 11

$\begin{array}{lll}1.2 & \text { De vooroever } & 11\end{array}$

$\begin{array}{llr}1.3 & \text { Het belang van de vooroever voor vis } & 12\end{array}$

$\begin{array}{lll}1.4 & \text { Onderzoek voorafgaand aan Natuurlijk Veilig } & 13\end{array}$

$2 \quad$ Kennisvraag en aanpak $r$

$\begin{array}{lll}2.1 & \text { Kennisvragen } & 14\end{array}$

$\begin{array}{llr}2.2 & \text { Aanpak } & 14\end{array}$

$\begin{array}{llr}2.3 & \text { Werkzaamheden } & 16\end{array}$

$\begin{array}{llr}2.4 & \text { Aanvullende studies } & 16\end{array}$

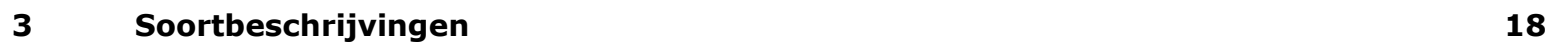

$\begin{array}{lll}3.1 .1 & \text { Schol } & 18\end{array}$

$\begin{array}{lll}3.1 .2 & \text { Tong } & 19\end{array}$

3.1.3 Tarbot en Griet $\quad 20$

4 Historische bemonsteringen $\quad 22$

$\begin{array}{llr}4.1 & \text { Introductie } & 22\end{array}$

4.2 Historische gegevens gebruikt in de analyse 23

4.3 Resultaten historische gegevens 23

$\begin{array}{lll}4.3 .1 & \text { Schol } & 23\end{array}$

$\begin{array}{lll}4.3 .2 & \text { Tong } & 24\end{array}$

$\begin{array}{lll}4.3 .3 & \text { Tarbot } & 26\end{array}$

$\begin{array}{lll}4.3 .4 & \text { Griet } & 26\end{array}$

$\begin{array}{lll}4.3 .5 & \text { Overige soorten } & 27\end{array}$

$\begin{array}{llr}4.4 & \text { Discussie } \& \text { conclusie } & 28\end{array}$

5 De huidige vooroever $\quad 29$

5.1.1 Kustvakken 2017-2018 29

5.1.2 Kustlangse bemonstering 2019-2020 34

$\begin{array}{lll}5.1 .3 & \text { Strandbemonstering } 2019 & 34\end{array}$

$\begin{array}{lll}5.2 & \text { Analyses } & 35\end{array}$

5.2.1 Sediment $\quad 35$

5.2.2 Principale componenten analyse $\quad 36$

5.2.3 Habitatmodellering 36

$\begin{array}{lll}5.3 & \text { Omgevingsvariabelen } & 36\end{array}$

5.3.1 Korrelgrootteverdeling van het sediment $\quad 36$

5.3.2 Ruimtelijke verspreiding sedimentsamenstelling 37

$\begin{array}{lll}5.4 & \text { Bodemdieren } & 39\end{array}$

$\begin{array}{lll}5.5 & \text { Zoöplankton } & 40\end{array}$

$\begin{array}{lll}5.6 & \text { Demersale vis } & 41\end{array}$

5.6.1 Kustvakken $\quad 41$ 
$\begin{array}{lll}\text { 5.6.2 Kustlangse bemonstering } & 47\end{array}$

5.6.3 Habitatmodellering kustvak- en kustlangse bemonstering met de Luctor $\begin{array}{ll}\text { gecombineerd } & 49\end{array}$

$\begin{array}{lll}\text { 5.6.4 Strandbemonstering } & 56\end{array}$

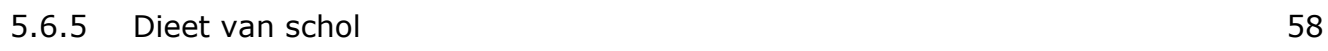

$\begin{array}{ll}\text { 5.6.6 DFS tijdserie } & 59\end{array}$

$\begin{array}{lll}5.7 & \text { Pelagische vis } & 61\end{array}$

$\begin{array}{lll}\text { 5.7.1 Strandbemonstering } & 61\end{array}$

$6 \quad$ Belang van de vooroever als kinderkamer $\quad 62$

7 Toekomstig groeipotentieel van platvis in ondiepe kustwateren in verschillende $\begin{array}{ll}\text { klimaatscenario's } & 67\end{array}$

$\begin{array}{llr}7.1 & \text { Introductie } & 67\end{array}$

$\begin{array}{llr}7.2 & \text { Temperatuurscenario's } & 67\end{array}$

$\begin{array}{llr}7.3 & \text { Resultaten } & 69\end{array}$

$\begin{array}{lll}7.4 & \text { Discussie } & 75\end{array}$

$\begin{array}{lll}7.5 & \text { Samenvatting } & 76\end{array}$

$8 \quad$ Conclusies en aanbevelingen $\quad 78$

$\begin{array}{lll}8.1 & \text { Soortensamenstelling in de vooroever } & 78\end{array}$

$\begin{array}{lll}8.2 & \text { Functioneren van de kustzone als opgroeigebied } & 78\end{array}$

$\begin{array}{lll}\text { 8.2.1 Vergelijking historisch en huidige dichtheden } & 78\end{array}$

8.2.2 Huidig functioneren: relaties met habitat, groei en dieet 79

8.2.3 Toekomstig functioneren: klimaatverandering (in combinatie met suppleties) 81

8.3 Relatie zandsuppleties en kinderkamerfunctie 82

8.4 Aanbevelingen voor het inrichten van suppleties 82

8.5 Aanbevelingen voor vervolgonderzoek 84

$9 \quad$ Kwaliteitsborging $\quad 86$

$\begin{array}{llr}10 & \text { Dankwoord } & 87\end{array}$

$\begin{array}{lr}\text { Literatuur } & \mathbf{8 8}\end{array}$

$\begin{array}{ll}\text { Verantwoording } & 95\end{array}$

$\begin{array}{lll}\text { Bijlage 1 Aangetroffen vissen } & 96\end{array}$

$\begin{array}{llr}\text { Bijlage } 2 & \text { Aangetroffen overige soorten } & 98\end{array}$

$\begin{array}{llr}\text { Bijlage } 3 & \text { Beschermingsdoelen } & 100\end{array}$

$\begin{array}{llr}\text { Bijlage } 4 \quad \text { Statistische analyse historische data } & 101\end{array}$

Bijlage $5 \quad$ Statistische analyse recente gegevens $\quad 103$

Bijlage 6 Omgevingsvariabelen $r 05$

$\begin{array}{llr}\text { Bijlage } 7 & \text { Zandmotor-bemonsteringen } & 107\end{array}$

$\begin{array}{llr}\text { Bijlage } 8 & \text { Resultaten GAM-analyse } & 108\end{array}$

$\begin{array}{llr}\text { Bijlage } 9 & \text { Tarbot en Griet } & 112\end{array}$

Bijlage 10 Vangstefficiëntie 2m boomkor $r$

$\begin{array}{llr}\text { Bijlage } 11 & \text { Modelbeschrijving DEB } & 118\end{array}$ 


\section{Samenvatting}

In opdracht van Rijkswaterstaat vinden regelmatig suppleties van zand plaats op vooroever, strand of duin. Het doel van de suppleties is om de Nederlandse kust tegen structurele erosie te beschermen en de kustlijn te behouden. Er is beperkt inzicht in de eventuele ecologische effecten van het suppleren in deze gebieden. Betere kennis van de effecten kan bijdragen aan het vermijden of mitigeren van nadelige effecten. Mogelijk zijn er zelfs kansen om gewenste natuurwaarden en ecosysteemdiensten te versterken. Vanuit dit oogpunt is er in 2009 een convenant tussen Rijkswaterstaat en natuurbehoudsorganisaties afgesloten over een onderzoeksprogramma om de ecologische effecten van suppleren nader in kaart te brengen. Dit onderzoeksprogramma liep in 2015 af waarna een vervolgconvenant is afgesloten met een nieuw onderzoeksprogramma voor de periode 2017-2021, onder de naam "Natuurlijk Veilig".

Het voorliggende rapport presenteert de bevindingen uit de onderzoekslijn "vooroever", gericht op de ecologie van vis en dan met name het belang van de vooroever als kinderkamer. De kennisleemtes en kennisvragen voor de vooroever in relatie tot suppleties waren voorafgaand in kaart gebracht door Herman et al. (2016). De hypotheses met betrekking tot het onderdeel ecologie van vis waren:

- Er zijn ruimtelijke gradiënten in de vooroever langs de Nederlandse kust, van Zeeland tot de Waddeneilanden, die de samenstelling van de gemeenschappen van benthos en vis, en daarmee de gevoeligheid van deze gemeenschappen voor suppleties beïnvloeden. Gradiënten kunnen scherp zijn bij geulen en buitendelta's. Een habitatclassificatie biedt de mogelijkheid effecten van (herhaalde) suppleties op levensgemeenschappen van benthos en vis te voorspellen.

- De vooroever is van groot belang voor de ontwikkeling van vispopulaties, vanwege de functie als kinderkamer. Veranderingen in de kinderkamerhabitat van de vooroever kunnen een significant effect hebben op de populaties, ook al treden ze slechts op in een ruimtelijk beperkte fractie van het verspreidingsgebied van de (adulte) populatie.

- Regelmatige suppleties leiden tot een cumulatieve verandering van fysische karakteristieken in de habitat van de ondiepe kustzone. Directe veranderingen betreffen met name korrelgrootteverdeling, steilheid van de vooroever, diepte en bankendynamiek. Indirect kunnen hiervan afhankelijke variabelen als zeewatertemperatuur, doorzicht en zoutgehalte worden beïnvloed. Als gevolg van verandering van deze habitatfactoren kunnen de levensgemeenschappen van vis en benthos wijzigen in overeenstemming met de gewijzigde fysische habitatkarakteristieken.

Deze hypotheses leiden er toe dat er in dit onderzoek gefocust is op vissoorten waarvoor de vooroever als substantieel deel van de kinderkamer werd beschouwd en er een directe relatie werd verwacht tussen voorkomen en de fysische karakteristieken: korrelgrootteverdeling en dieptegradiënt. De gekozen bemonsteringsmethoden leveren ook gegevens op over andere soorten in de vooroever maar in veel gevallen zijn deze gegevens niet toereikend om voor deze soorten uitspraken te doen. Er zijn ook gegevens over pelagische vis verzameld omdat er over het voorkomen van deze soorten in de vooroever nagenoeg niets bekend was. Voor deze groep verwachten we, afgezien van zandspiering, geen directe link met de korrelgrootte.

\section{Aanpak en uitgevoerd veldonderzoek}

Om de geschiktheid van een gebied als kinderkamer te kunnen meten, is het zinvol om metingen te doen aan de directe processen waaruit de kwaliteit afgeleid kan worden: immigratie, emigratie, groei en sterfte. Vanuit pragmatisch oogpunt is dat echter een intensieve en kostbare aanpak. In het onderzoek is er daarom gekozen om als resultante van die processen de visdichtheid als belangrijkste (response)parameter te gebruiken.

Om de kennisvragen te kunnen beantwoorden zijn historische veldgegevens van de vooroever en de kustzone gecompileerd en, waar nodig, gedigitaliseerd. Om inzicht te krijgen in de recente situatie 
met betrekking tot vis is er vier jaar veldwerk verricht. Vanwege financiële redenen, praktische redenen en voortschrijdend inzicht is het veldwerk jaarlijks bijgesteld. In het eerste jaar, 2017, zijn er gedurende vier weken in juni/juli in de vooroever bij Zuid-Holland, Noord-Holland, Texel en Ameland (kustvakken) gegevens over demersale en pelagische vis, benthos, zoöplankton, sedimenten en hydrologie verzameld. In ieder kustvak werd hiervoor op zeven verschillende dieptes op vijf verschillende raaien loodrecht op de kust bemonsterd. In het tweede jaar, 2018, is in juni een vergelijkbare opzet uitgevoerd in alleen het kustvak Schiermonnikoog. In 2019 is op basis van beschikbare scheepstijd besloten een andere bemonsteringsopzet te volgen. In juni is parallel aan de kust vanaf de Maasvlakte tot aan Texel op 62 stations op een diepte van 4-6 $\mathrm{m}$ en 7 stations op een diepte van 6-16 m de demersale visfauna en het sediment bemonsterd. Aanvullend is vanaf maart tot juli om de twee weken vanaf het strand rond laag water vis bemonsterd met een sleepnet in de brandingszone bij Katwijk, Castricum en Texel. In juni 2020, is de kustlangse bemonstering herhaald maar nu vanaf IJmuiden tot en met Texel en een aantal locaties in de Waddenzee. Toen zijn op een diepte van 3-6 m 57 stations en op een diepte van 7-12 m 24 stations bemonsterd.

Aanvullend is door vrijwilligers van juli tot oktober 2019 nabij Egmond aan Zee de bemonstering vanaf het strand voortgezet. In 2020, hebben de vrijwilligers het hele jaar deze bemonstering voortgezet en heeft WMR vanaf maart een vergelijkbare bemonstering vanaf het strand bij IJmuiden opgezet. Als studentenonderzoek zijn tijdens de Natuurlijk Veilig bemonsteringen in 2017 platvissen verzameld om de instantane groei op basis van RNA:DNA-ratio's te onderzoeken. In 2019 zijn tijdens de kustlangse en strandbemonsteringen platvissen, met name schol, verzameld om als studentenonderzoek de dieetsamenstelling te bepalen met behulp van DNA-metabarcoding.

\section{Historische gegevens van de vooroever}

Beschikbare historische gegevens over vis in de vooroever zijn erg beperkt. De kennis over de kinderkamers van juveniele vis in de Nederlandse wateren is vooral gebaseerd op bemonsteringen in de Waddenzee vanaf de jaren 1960 en de Demersale Fish Survey (DFS) uitgevoerd in het najaar sinds 1970 in water dieper dan $5 \mathrm{~m}$. Nagenoeg de enige beschikbare voorjaargegevens komen uit de periode 1970-1986 toen de DFS ook in het voorjaar uitgevoerd werd. In het ondiepe gebied < $5 \mathrm{~m}$ zijn in de periode 1974-1985 opportunistische bemonsteringen vanaf het strand verspreid over het jaar op verschillende locaties langs de Nederlandse kust uitgevoerd. De vangsten van de historische strandbemonstering en de DFS laten zien dat in ieder geval 0- en 1-jarige schol, tong, tarbot en griet gebruik maakten van de vooroever. Juveniele schol werd in gemiddeld hogere dichtheden aangetroffen tot 5 meter diepte. Juveniele tong maakte nauwelijks gebruik van de brandingszone en de hoogste dichtheden werden aangetroffen tussen de 2 en $5 \mathrm{~m}$ diepte. 0-jarige tarbot en griet vestigden zich met name in de brandingszone, naar mate ze groeien maakten ze het gehele jaar door gebruik van de vooroever.

\section{Recente soortsamenstelling in de vooroever}

Tijdens de Natuurlijk Veilig-bemonsteringen (2017-2020) was 0-jarige schol de meest dominante demersale vissoort, daarnaast zijn nog 36 andere demersale en 12 pelagische soorten gevangen. Ondanks grote variatie in de samenstelling van de demersale vangsten vinden we in juni geen sterke relatie met de verschillende gebieden, dieptes of sedimentsamenstelling in de vooroever. Alleen de vangstsamenstelling in de Waddenzee in 2020 wijkt af van de overige vangsten vooral door de aanwezigheid van juveniele tong en vijfdradige meun. In de brandingszone, waar de bemonsteringen zijn uitgevoerd door het jaar heen, wordt een deel van de variatie in de vangsten veroorzaakt doordat de juvenielen van verschillende soorten op andere momenten in het jaar aankomen in de vooroever.

\section{Vergelijking historische en huidige dichtheden}

De dichtheden 0-jarige schol aangetroffen in de recente jaren in de vooroever zijn, na correctie voor vangstefficiëntie, in dezelfde ordegrootte als dichtheden binnen hetzelfde seizoen (juni/juli) waargenomen in eerdere jaren in andere kinderkamergebieden zoals de Waddenzee. Het algemene beeld, en dat is ook het geval in de vangsten van de recente strandbemonsteringen, is dat in de kinderkamergebieden de dichtheden juveniele schol vanaf het vroege voorjaar (maart-april) toenemen tot piekdichtheden in mei-juni, waarna de dichtheden weer (snel) afnemen. Uit de beschikbare data komt dat gemiddeld hogere dichtheden van schol werden aangetroffen in de zone tot 5 meter. Echter, trendanalyses op basis van de najaars-DFS laten voor 0 -jarige schol een toename in dichtheden zien 
tussen 10 en 25 m diepte ten opzichte van de ondiepste zone (5-10 m), in de recentere jaren werd over de gehele vooroever (5-25 m diepte) vergelijkbare dichtheden gevangen. De dichtheden in de zone 10-25 m zijn iets toegenomen terwijl die in de zone $<10 \mathrm{~m}$ lijken te zijn afgenomen. Deze verandering in gebruik van de vooroever suggereert dat de kinderkamer groter is geworden.

Tong is in veel lagere aantallen gevangen dan schol in de Natuurlijk Veilig bemonsteringen en is helemaal niet aangetroffen in de vistrekken uitgevoerd in de brandingszone. De hoogste dichtheden werden aangetroffen tussen $2-5 \mathrm{~m}$. In het beperkte aantal vistrekken uitgevoerd in de Waddenzee in 2020 werden aanmerkelijk hogere dichtheden juveniele tong aangetroffen dan in de vooroever. Dit is niet in lijn met historische bevindingen dat de kustzone van groter belang was als kinderkamer voor tong dan de Waddenzee. Trendanalyse op basis van de najaars-DFS suggereren een afname in de dichtheden van juveniele tong in de kustzone rond de jaren 1990 waarna de dichtheden op dit lagere niveau zijn gebleven.

Tarbot en griet werden in zeer beperkte aantallen gevangen. Vanwege de geringe aantallen en om toch inzicht te krijgen in de diepteverspreiding is gebruik gemaakt van data uit meerdere monitoringsprogramma's. Hieruit wordt het beeld van een sterke voorkeur van juveniele tarbot en griet voor de ondiepe kustwateren $(0-5 \mathrm{~m})$ bevestigd.

\section{Huidig functioneren: relaties met habitat, groei en dieet}

De dichtheden van de meest gevangen soorten zijn gecorreleerd aan de abiotische omgevingsvariabelen, diepte, korrelgrootte/slibgehalte, saliniteit en doorzicht. Een correlatie met sediment is gevonden voor tong (slibgehalte), grondel en zandspiering (korrelgrootte). Een correlatie met diepte is gevonden voor schar, wijting, grondel en zandspiering. Op grondel na correleerden de dichtheden van alle soorten positief met saliniteit. Doorzicht, vermoedelijk in relatie tot vangstefficiëntie, was voor de meeste soorten significant. Alleen voor soorten waar een relatie met sediment of diepte gevonden is, is het zinvol om met een habitatmodel mogelijke effecten van suppleties via verandering in sediment en diepteprofiel te voorspellen.

De Natuurlijk Veilig-bemonsteringen lieten geen verschil zien in de gemiddelde lengtes van schol en tong tussen gebieden langs de kust in juni/juli. Alleen voor schol zijn voldoende exemplaren gevangen om de groei over het seizoen te bepalen op basis van de strandbemonsteringen. De groei over het seizoen verliep vergelijkbaar op de verschillende locaties van de strandbemonstering in 2019 en 2020 , en lijkt in ieder geval in het begin van het groeiseizoen optimaal te zijn voor de geldende temperatuuromstandigheden. De voedselbeschikbaarheid en -kwaliteit op de bemonsterde locaties van de vooroever blijkt dus ruim voldoende te zijn en concurrentie om voedsel lijkt geen rol te spelen. De RNA-DNA-analyses uitgevoerd op de platvis gevangen in de bemonsteringen van 2017 onderbouwen dit. Er werd geen verschil gevonden in recente groei tussen de verschillende kustvakken. Alleen voor schar was er verschil, maar dit leek vooral veroorzaakt door het verschil in bemonsteringsperiode van de verschillende kustvakken.

De aanwezigheid van voldoende voedsel betekent niet dat dit overal hetzelfde voedsel is. De analyses van dieet van schol op basis van DNA-metabarcoding laten geen significante verschillen tussen locaties, maar laten wel een grote variatie in prooisoorten zien. Veel van de in het dieet aangetroffen prooisoorten werden niet (goed) bemonsterd tijdens het veldwerk waardoor er geen ruimtelijk beeld gemaakt kan worden van de voedselbeschikbaarheid.

\section{Toekomstig functioneren: klimaatverandering (in combinatie met suppleties)}

Klimaatverandering leidt ook in de vooroever tot een toename van de watertemperatuur. Voor verschillende temperatuurscenario's is het waarschijnlijke gevolg hiervan voor schol en tong geanalyseerd. Voor schol zal de kwaliteit van de ondiepe wateren door de voorspelde toename van temperatuur op de lange termijn afnemen, echter zal het belang van de vooroever als kinderkamer voor de populatie schol in eerste instantie toenemen omdat de temperatuurstijging een grotere invloed zal hebben op de temperaturen in de Waddenzee, met name de Eems-Dollard. Voor tong daarentegen zijn de voorspelde toenames in watertemperatuur gunstig en laten de voorspellingen een verbetering van de habitatkwaliteit zien.

De gevolgen van klimaatverandering gaan voor meer soorten vergelijkbare effecten hebben, waardoor het aannemelijk is dat de huidige soortsamenstelling zal veranderen ongerelateerd aan de gevolgen van suppleties. Het is bij het aanleggen van suppleties niet alleen nodig rekening te houden met de 
recente vis/bodemgemeenschappen, maar ook rekening te houden met de verwachte

gemeenschappen, bestaande uit mogelijk andere soorten, en de eisen die deze stellen aan de habitat. Wanneer zandsuppleties aanzienlijk het diepteprofiel veranderen, kan dat in combinatie met klimaatverandering het effect van klimaatverandering versterken of verzwakken (afhankelijk van de verandering in het profiel).

\section{Relatie zandsuppleties en kinderkamerfunctie}

De directe en korte termijn gevolgen van zandsuppleties op vis lijken op basis van studies na de uitvoering van suppleties (vooroever Ameland en Mariakerke, Belgium, de Zandmotor en de buitendeltasuppletie Ameland) beperkt. De beperkte ruimtelijke schaal waarop de huidige suppleties plaatsvinden hebben, zelfs als er lokale gevolgen zijn, geen effect op de populatieomvang van de soorten die wijdverspreid zijn in de vooroever. Aangezien er geen uitzonderlijke locaties met hoge biodiversiteit of hoge dichtheden zijn aangetroffen lijkt ook de locatie van eventuele suppleties geen rol te spelen.

Op langere termijn zouden suppleties een vergroving van het sediment tot gevolg kunnen hebben, als er gesuppleerd wordt met sediment dat duidelijk grover is dan wat er nu op de locaties aanwezig is. Voor de onderzochte soorten lijkt een vergroving binnen de verwachte range geen gevolgen te hebben. Als gevolg van vergroving van het sediment door suppleties zal het kustprofiel (een beetje) steiler worden, doordat meer sediment in ondiep water zal blijven 'hangen'. Deze verandering in kustprofiel lijkt voor de onderzochte soorten binnen hun huidige voorkeursrange aan dieptes te liggen waardoor dit bij de huidige klimatologische omstandigheden hoogstwaarschijnlijk niet zal leiden tot effecten op populatieniveau.

\section{Aanbevelingen voor het inrichten van suppleties}

De gecombineerde bevindingen uit historische data, verschillende databronnen en de Natuurlijk Veiligbemonsteringen zijn gebruikt in het opstellen van aanbevelingen bij de huidige suppletievolumes en bij toekomstige grotere volumes.

Vanuit het oogpunt van vis zijn er op de ruimtelijke schaal van de Nederlandse vooroever geen gebieden gevonden die van cruciaal belang zijn en vermeden zouden moeten worden. Daarnaast heeft het op de korte termijn voortzetten van de huidige suppletiestrategie hoogstwaarschijnlijk geen gevolgen voor de populatieomvang van de vissoorten die gebruik maken van de vooroever. Dit leidt echter wel tot mortaliteit op de locatie van suppleren die mogelijk vermeden kan worden. Mitigerende maartregelen om directe sterfte te reduceren zijn:

- Suppleren buiten het seizoen waarin jonge vis in het gebied voorkomt: in de periode oktober tot maart;

- $\quad$ Een voorkeur voor strandsuppleties boven vooroeversuppleties

- Suppletietechnieken gebruiken waarbij sediment in een dunnere laag over een groter gebied wordt verspreid.

- $\quad$ Sediment gebruiken dat de samenstelling van het sediment in het suppletiegebied benadert.

Daarnaast zou de habitatkwaliteit voor tong verbeterd kunnen worden door te suppleren met slibrijk sediment en gebieden te creëren waar dit blijft liggen.

Aanbevelingen voor toekomstige (veel grotere) volumes richten zich op het ontwikkelen van een gevarieerde (en dynamische) brandingszone. Met de grotere volumes zouden langgerekte banken, geulen en luwten passend bij de natuurlijke morfologische dynamiek gecreëerd kunnen worden, aansluitend op natuurlijke kustfenomenen als slufters en groene stranden. Bestaande bankenstructuren verondiepen en mogelijk zelfs (tijdelijke) droogleggen waardoor langgerekte eilanden parallel aan de huidige kust ontstaan, zou voor vis een positief effect kunnen hebben omdat daarmee het oppervlak geschikt habitat vergroot wordt. Bovendien ontstaat er zo meer variatie aan microhabitats die mogelijk leefruimte bieden aan meer soorten dan de soorten die we er nu vooral aantreffen.

\section{Aanbevelingen voor vervolgonderzoek}

Bij de interpretatie van de veldgegevens missen we gegevens van de recente periode in het voorjaar, en eigenlijk over seizoensdynamiek gedurende het hele jaar. Hierdoor hebben we geen zicht op verschuivingen in de fenologie. Om hier een beter beeld van te krijgen is bemonstering door het 
gehele jaar heen nodig. Voortzetting van de bemonstering van de brandingszone is zinvol, omdat dat op een kosteneffectieve manier een heel goed beeld geeft van de variatie in tijd (en ruimte wanneer meer plekken meegenomen worden) van juveniele vis.

Het belang van de kinderkamergebieden voor de volwassenpopulatie wordt nu vooral bepaald op basis van de hoeveelheid juveniele vis die op een bepaald moment aanwezig is in het gebied. Om het relatieve belang van een kinderkamergebied aan de volwassenpopulatie in kaart te brengen kunnen verschillende technieken ingezet worden.

Visbemonsteringen laten meestal een grote variatie in vangsten zien. Dat is in de vooroever wellicht nog sterker het geval dan in dieper water omdat de omstandigheden hier nog variabeler zijn en die mede de vangbaarheid van vissen bepalen. In de ondiepe vooroever lijken de aanwezigheid van banken, geulen, muien en poeltjes (kleinschalige habitats) een deel van deze variatie te kunnen verklaren. Mogelijk geldt dit ook voor andere structuren zoals de strandhoofden en kunstwerken in de havenmondingen, waarover in de Nederlandse vooroever nagenoeg geen kennis aanwezig is. De invloed van de lokale omstandigheden zou verder onderzocht kunnen worden.

Een belangrijk oorzaak van de variatie in visdichtheden voor een gebied, is hoogstwaarschijnlijk de aanwezigheid van prooisoorten en de afwezigheid van predatoren. Uitbreiding van kennis over de voedselweb-relaties met name in de vooroever zou de link tussen bodemfauna en vis kunnen verduidelijken. De studentenonderzoeken die op basis van DNA de dieetsamenstelling analyseerden waren vooral gericht op het ontwikkelen van de methode. Uitgebreidere toepassing van deze methodes kunnen inzicht geven in dieet en groei op grotere schaal.

Een deel van het huidige onderzoek was er op gericht om de huidige vooroever te vergelijken met de situatie voor de eerste suppleties. Uit die periode zijn echter geen sedimentgegevens beschikbaar. Het ontbreken van een relatie tussen sediment en het voorkomen van de meeste vissoorten houdt wellicht verband met de lage variatie in sedimentsamenstelling in de bemonsteringen. Voor de kustzone zou het uitbreiden van de vissurveys en de WOT-schelpdiersurvey met het verzamelen van sedimentmonsters van grote toegevoegde waarde zijn. Relaties tussen vis en sedimentvoorkeuren in het veld kunnen dan wellicht over een grotere range aan korrelgroottes gelegd worden. Het uitvoeren van lab/mesocosm experimenten om de voorkeur van verschillende soorten en groottes beter uit te zoeken zou daarop een waardevolle aanvulling zijn.

Enig inzicht in de aanwezigheid van pelagische vis in de vooroever is verkregen door middel van de akoestische opnames en de gegevens uit de strandbemonsteringen. Voor zover bij ons bekend waren dit de eerste bemonsteringen van pelagische vis in de ondiepe kustzone. Meer inzicht in de aanwezigheid van de pelagische vis in dit gebied is ecologisch uitermate relevant omdat pelagische vis belangrijk voedsel vormt voor zeevogels, zeehonden en bruinvissen in de kustzone. Het voorkomen van pelagische vis bepaalt waarschijnlijk voor een groot deel de verspreiding van zeevogels en zeezoogdieren. Naast de soorten als haring, sprot en zandspiering werd ook duidelijk dat de vooroever gebruikt wordt door juveniele zeebaarzen en (goud)harders. Dit zijn soorten die in de reguliere visbemonsteringen nagenoeg niet gevangen worden en waarover, met name de juvenielen, zeer beperkte kennis is. De hoge aantallen die gevangen zijn in de branding suggereren dat de brandingszone en mogelijk de ondiepe kustzone ook voor deze soorten een kinderkamerfunctie heeft en dat er mogelijk in de nabijheid van de kust ook gepaaid wordt door zeebaars. Aanvullend onderzoek gericht op pelagische soorten in de vooroever wordt aanbevolen. 


\section{Begrippenlijst}

Brandingsstroom: Stroming evenwijdig aan de kust in de brekerzone die aangedreven wordt door het breken van scheef invallende golven.

Brandingszone: het gebied vanaf het strand tot ongeveer de buitenste brekerbank. Het is de zone waarbinnen de naar het strand toe rollende golven breken, ook wel brekerzone.

Demersaal: Levend in de buurt of op de bodem van de zee.

Getijstroom: De horizontale waterbeweging onder invloed van het getij.

Golfbreker: Een constructie (kunstwerk) parallel aan de kustlijn, in de Nederlandse kustwateren vooral gebouwd ter bescherming van haveningangen.

Kinderkamer/opgroeigebied: Het gebied waar vissenlarven zich vestigen om er vervolgens op te groeien. Voor de meeste vissen is de kinderkamer een ander gebied dan de kraamkamer waar de eieren zijn afgezet.

Kraamkamer/paaigebied: Het gebied waar vissen hun eieren afzetten. Omdat veel vissen pelagische eieren hebben die meedrijven met de stroming komen de eieren meestal buiten de kraamkamers uit. De uitgekomen larven zijn meestal ook pelagisch en drijven verder mee met de stroming.

Mesocosm: Een experimenteel systeem in de openlucht, waarin de natuurlijke omgeving wordt nagebootst en gemanipuleerd kan worden onder gecontroleerde condities.

Pelagisch: De gehele waterkolom van bodem tot oppervlak. Pelagische organismen leven dus vrij in de waterkolom, niet gebonden aan de bodem.

Soortenpool (Species pool): Het ecologische en biogeografische concept van de soortenpool beschrijft alle beschikbare soorten die mogelijk een concentratiegebied zouden kunnen koloniseren en bewonen.

Strandhoofd: Een dwars op de kust staande stenen of houten constructie, meestal gebouwd om erosie te vertragen.

Vooroever: Gedeelte van de kuststrook zeewaarts van de laagwaterlijn tot een diepte waarop de invloed van golven op sedimenttransport verwaarloosbaar is, ook wel onderwateroever genoemd. 


\section{$1 \quad$ Inleiding}

\subsection{Achtergrond}

Suppleties van zand op vooroever, strand of duin worden al vanaf ongeveer 1970 op regelmatige basis in opdracht van Rijkswaterstaat aangebracht om de Nederlandse kust tegen structurele erosie te beschermen en de kustlijn te behouden. Deze strategie wordt sinds enige decennia in Nederland toegepast, en bestrijdt erosie van de zandige kust.

Een groot deel van de suppleties vindt plaats in of nabij de kuststrook die onder Natura2000 regelgeving valt. In het kader van deze regelgeving is het van belang de eventuele effecten van suppleties op de natuur zorgvuldig te bestuderen, zodat dit effect kan worden afgezet tegen het algemene nut voor de samenleving. Betere kennis van de effecten kan leiden tot vermijden of mitigeren en mogelijk zelfs tot versterken van gewenste natuurwaarden en ecosysteemdiensten. In een convenant in 2009 tussen Rijkswaterstaat en natuurbehoudsorganisaties werd afgesproken dat een onderzoeksprogramma de ecologische effecten nader in kaart zou brengen en zou zoeken naar eventuele verbeteringen van de praktijk (Ministerie van Verkeer en Waterstaat 2009). Dit convenant leidde tot uitvoering van het programma "Ecologisch gericht suppleren, nu en in de toekomst" (Holzhauer e.a., 2009). Dit programma is in 2015 afgelopen waarna met de natuurbeschermingsorganisaties werd overeengekomen dat er een vervolg zou worden gegeven aan het onderzoek naar effecten van suppleren en maatregelen voor kustveiligheid op de ecologie van de Nederlandse kust. Dit vervolg werd opnieuw ondersteund door een convenant, onder de naam "Natuurlijk Veilig".

In een voorstudie t.b.v. het Natuurlijk Veilig programma zijn de vraagstukken voor mogelijke effecten van zandsuppleties op de ecologie van de Nederlandse kust beschreven (Herman e.a., 2016). Het doel was te onderzoeken hoe suppletiestrategieën in de nabije toekomst kunnen bijdragen aan het kustbeheer in samenhang met het kustecosysteem. De vraagstukken en kennisleemtes dienden als basis voor het onderzoeksprogramma in het kader van Natuurlijk Veilig (NV). Het onderzoeksprogramma bestond uit de onderzoekslijnen duinen en vooroever.

In de periode 2017-2021 is er onderzoek uitgevoerd binnen de onderzoekslijn vooroever. De focus lag op de functie van de vooroever voor vis. In deze rapportage wordt verslag gedaan van de uitgevoerde werkzaamheden, hoe de verzamelde kennis gebruikt is om een beter begrip te krijgen van het functioneren van de vooroever voor vis en hoe die kennis kan worden ingezet in de suppletiepraktijk via aanpassing en/of aanvulling van de richtlijnen voor suppleren.

\subsection{De vooroever}

Deze studie onderzoekt de vooroever, de zone tussen de laagwaterlijn en een diepte waarop de invloed van golven op sedimenttransport verwaarloosbaar is, doorgaans gekozen op zo'n 12 m diepte. De vooroever van de Nederlandse kust wordt gekenmerkt door zandig sediment. Het zuidelijke deel van de Nederlandse vooroever bestaat uit de Zeeuwse Delta/Voordelta waar grote invloed is van de deltawerken en de aanleg van de Tweede Maasvlakte. Dit gebied is uitvoerig onderzocht in het project PMR Monitoring natuurcompensatie Voordelta (Tulp e.a., 2016a) en is geen onderdeel van het Natuurlijk Veilig onderzoek.

Vanaf Europoort tot aan Den Helder ligt de Hollandse kust, door de licht holle vorm zijn de gradiënten in het brandingsstroomtransport beperkt, en treedt er in het middelste gedeelte aanzanding op en op de uiteinden erosie. Langs een groot deel van deze kust worden brekerbanken gevormd. Deze zijn, met name onder invloed van storm, zeer dynamisch. Vaak liggen er evenwijdig aan de kust meerdere brekerbanken, die zorgen voor een natuurlijke kustverdediging. De ruimten tussen deze banken worden zwinnen genoemd. De golven breken op de zandbank, waardoor er witte schuimkoppen ontstaan. Loodrecht op de kust liggen muien, die de brekerbanken doorsnijden. Tijdens vloed stroomt 
het water eerst door deze muien tot dat de banken worden overstroomd, bij eb stromen de zwinnen via de mui als laatste leeg. De Hollandse kust wordt onderbroken door golfbrekers zoals de havendammen bij Hoek van Holland, Scheveningen en IJmuiden.

Ten noorden van Den Helder ligt het Marsdiep, de ingang naar de Waddenzee, met aan de Noordzeezijde de Noorderhaaks. Ten noorden daarvan beginnen de Waddeneilanden, onderbroken door de verschillende zeegaten met de buitendelta's. Langs de eilanden komen zandgolven voor die aan de westzijde van de eilanden aanlanden, en vervolgens oostwaarts migreren. Langs de stranden bevindt op de meeste plaatsen een vergelijkbaar brekerbankensysteem als langs de Hollandse kust. $\mathrm{Al}$ in de $19^{\text {de }}$ eeuw zijn langs de Hollandse kust, Texel en Vlieland strandhoofden aangelegd om erosie te vertragen (Rakhorst, 1984). En al vanaf ongeveer 1970 vinden er kustsuppleties plaats die tot doel hebben het zandverlies te compenseren. Naast suppleties in de Zeeuwse Delta, vonden deze tot 1985 plaats bij Hoek van Holland, Scheveningen, Callantsoog, Texel: De koog en Eierland, en op Ameland (Pilarczyk e.a., 1988). Sindsdien zijn suppleties veelvuldig toegepast, de toepassing en het volume van vooroeversuppleties neemt sinds 1990 toe, met als grootste suppletie de aanleg van de Zandmotor bij Ter Heijde in 2011.

De vooroever valt binnen de Habitatrichtlijn in habitattype 1110B: permanent overstroomde zandbanken (Noordzee kustzone). Het gebied ten noorden van het Noord-Hollandse Bergen tot aan de Eems boven Rottum is aangewezen als N2000-gebied Noordzeekustzone. Een van de beschermingsdoelen voor dit gebied is verbeteren van natuurlijke opbouw van vispopulaties, door verbeteren opgroeigebied voor vooral jonge haring, tong, schol en andere (plat)vissoorten (Bijlage 3).

\subsection{Het belang van de vooroever voor vis}

Vispopulaties hebben een groot verspreidingsgebied, waarvan de vooroever een beperkt deel beslaat. Populatie-effecten van suppleties zijn te verwachten als de kuststrook een buitenproportioneel groot belang heeft voor de populatie als geheel of tijdens een bepaald deel van de levenscyclus, zoals het geval kan zijn voor de kinderkamerfunctie van juveniele vis (Rijnsdorp e.a., 1992b; Teal e.a., 2012). Zo is aangetoond dat de populatiegrootte van bijvoorbeeld tong gerelateerd is aan het oppervlak van geschikt kinderkamergebied (Rijnsdorp e.a., 1992a; van de Wolfshaar e.a., 2015). Wanneer de vooroever dus een substantieel deel van de kinderkamer uitmaakt, is deze zone relevant omdat er dan een rechtstreeks verband is met de gehele populatie (grootte).

De levenscyclus van veel Noordzeevissoorten bestaat uit een opeenvolging van ei, larvaal, juveniel en uiteindelijk een volwassenstadium, waarbij de levensstadia (deels) overlappen maar vaak ook volledig gescheiden zijn in ruimte en tijd. In alle gevallen is een opeenvolging van geschikte habitats voor de verschillende levensfasen vereist om de levenscyclus te kunnen voltooien. Als levensfasen ruimtelijk gescheiden zijn, moeten de locaties die ze achtereenvolgens gebruiken met elkaar worden verbonden om de habitat te bereiken die nodig is voor de volgende levensfase (Höffle e.a., 2018). In dit opzicht zijn veel platvissen typerend omdat hun levenscyclus afhankelijk is van zowel pelagische als demersale habitats. Hun pelagische fase omvat na de ontwikkeling van de eieren een larvale fase waarin ze eerst leven van hun dooierzak en zich vervolgens voeden met zoöplankton. Hierna metamorfoseren ze met een afvlakking van het lichaam en migratie van één oog naar de bovenzijde, gevolgd door vestiging en een overgang naar een demersale manier van leven tijdens hun juveniele en volwassenstadium. Na metamorfose vestigen een aantal soorten zich in ondiepe kustgebieden waar ze hun jonge levensfase doorbrengen (Gibson, 1994). De Noordzee herbergt een aantal platvissoorten, waarbij elke soort wordt gekenmerkt door een specifieke levenscyclus, habitatvereisten en verspreiding (Heessen e.a., 2015). De juveniele stadia van een aantal van deze soorten, zoals schol (Pleuronectes platessa), bot (Platichthys flesus), tong (Solea solea), griet (Scophthalmus rhombus), tarbot (Scophthalmus maximus) en in mindere mate schar (Limanda limanda) concentreren zich in relatief ondiepe gebieden rond de Noordzee. De internationale Waddenzee, de Theemsmonding en de kustgebieden zijn historisch gezien de grootste kinderkamers voor platvis in de Noordzee. Afgezien van platvis zijn de kustwateren ook belangrijke opgroeigebieden voor een aantal rondvissoorten, zoals zandspieringachtigen (Ammodytes sp.), zeebaars (Dicentrarchus labrax), kabeljauwachtigen, harderachtigen, haring (Clupea harengus) en sprot (Sprattus sprattus). 
Populatie-dynamische processen die de kwaliteit van een kinderkamer voor vis bepalen zijn immigratie, groei, sterfte en emigratie. Tot de start van het Natuurlijk Veilig programma (en de voorgangers) werd eenmaal per jaar in de nazomer, de aanwezigheid van jonge vis in de ondiepe kustwateren gemeten door de Demersal Fish Survey (DFS, Van Beek (1997)). De dichtheid op dat moment is het resultaat van deze vier processen en wordt gebruikt als index voor de nieuwe jaarklasse als input voor bestandsschattingen. In veel studies zijn genoemde parameters gehanteerd om het functioneren van gebieden als opgroeigebied voor vis te kwantificeren en gebieden te vergelijken (Ciotti e.a., 2013a; Ciotti e.a., 2013b; Vasconcelos e.a., 2014).

Alhoewel de DFS-survey de ondiepe wateren beslaat, wordt de brekerzone, op dieptes minder dan enkele meters, niet bemonsterd. Dit is bij uitstek de zone die belangrijk geacht wordt voor met name tarbot en griet. Voor zandsuppleties is dit echter het gebied dat het meest wordt beïnvloed. Om een beter begrip te krijgen van het functioneren van juist deze zone moest het onderzoeksgebied dus verder landwaarts uitgebreid worden en ook moesten de processen die bepalend zijn voor de kwaliteit van een opgroeigebied beter bestudeerd worden.

\subsection{Onderzoek voorafgaand aan Natuurlijk Veilig}

Als eerste stap naar een beter begrip van de functie van de vooroever voor vis is een verkennende aanpak gehanteerd door middel van habitatgeschiktheidsmodellering (Wolfshaar e.a., 2009; Glorius e.a., 2012). In een vervolgstap is door middel van populatiedynamische modellering (van de Wolfshaar e.a., 2015) de consequentie van veranderingen in het functioneren van de vooroever op de populaties doorgerekend. Beide benaderingen zijn beperkt in hun toepasbaarheid omdat veldgegevens over voorkomen van vis in de vooroever erg beperkt waren. Habitatmodellering gekoppeld aan populatiemodellering kan gebruikt worden om vast te stellen of fysische veranderingen in de relatief nauwe kuststrook relevant zijn voor vispopulaties van zowel commercieel beviste als niet-commerciële vissoorten. Zo kunnen de effecten van fysische veranderingen als gevolg van suppleties op de ontwikkeling van vispopulaties in de Nederlandse kustwateren onderzocht worden. Hiervoor is het van belang dat het voorkomen, en bij voorkeur ook de processen die dat voorkomen bepalen (immigratie, emigratie, groei en sterfte), van juveniele vis in de vooroever wordt onderzocht in relatie tot overige (a)biotische parameters zoals benthos (als voedsel), predatoren, sedimentsamenstelling, morfologie en dynamiek. 


\section{Kennisvraag en aanpak}

\subsection{Kennisvragen}

Aan het onderzoek dat is uitgevoerd in de periode 2017-2021 lag een aantal basishypothesen ten grondslag.

- Er zijn ruimtelijke gradiënten in de vooroever van Zeeland tot de Waddeneilanden, die de samenstelling van de gemeenschappen van benthos en vis, en daarmee de gevoeligheid van deze gemeenschappen voor suppleties beïnvloeden. Gradiënten kunnen scherp zijn bij geulen en buitendelta's. Een habitatclassificatie biedt de mogelijkheid effecten van (herhaalde) suppleties op levensgemeenschappen van benthos en vis te voorspellen.

- De vooroever is van groot belang voor de ontwikkeling van vispopulaties, vanwege de functie als kinderkamer. Veranderingen in de kinderkamerhabitat van de vooroever kunnen een significant effect hebben op de populaties, ook al treden ze slechts op in een ruimtelijk beperkte fractie van het verspreidingsgebied van de (adulte) populatie.

- Regelmatige suppleties leiden tot een cumulatieve verandering van fysische karakteristieken in de habitat van de ondiepe kustzone. Directe veranderingen betreffen met name korrelgrootteverdeling, steilheid van de vooroever, diepte en bankendynamiek. Indirect kunnen hiervan afhankelijke variabelen als zeewatertemperatuur, doorzicht en zoutgehalte worden beïnvloed. Als gevolg van verandering van deze habitatfactoren kunnen de levensgemeenschappen van vis en benthos wijzigen.

Deze hypotheses leiden er toe dat er in dit onderzoek gefocust is op vissoorten waarvoor de vooroever als substantieel deel van de kinderkamer werd beschouwd en er een directe relatie werd verwacht tussen voorkomen en de fysische karakteristieken: korrelgrootteverdeling en dieptegradiënt. De gekozen bemonsteringsmethoden leveren ook gegevens over andere soorten in de vooroever maar in veel gevallen zijn deze gegevens niet toereikend om voor deze soorten uitspraken te doen. Voor pelagisch vis werd er geen directe link met de korrelgrootte verwacht (behalve voor zandspiering), maar ondanks het belang voor het ecosysteem is er over deze soorten geen kennis. Daarom is er voor gekozen om ook de pelagische vis te bemonsteren.

Gaandeweg het onderzoek zijn onderzoeksvragen bijgesteld. Bovenstaande generieke vragen zijn daarom verder geconcretiseerd. De resulterende vragen zijn:

1. Welke (a)biotische factoren zijn het belangrijkst in het verklaren van de verspreiding van vis in de vooroever?

2. Zijn er grote verschillen in visdichtheden en kwaliteit van het gebied voor vis tussen deelgebieden?

\subsection{Aanpak}

Herman e.a. (2016) stelden voor om bestaande datasets over benthos en vis in de vooroever te compileren en te relateren aan de fysische habitatkarakteristieken van de monsterlocaties. Aanvullend werd voorgesteld om in de eerste twee jaar nieuwe gegevens te verzamelen over de aanwezigheid van zowel bodemgebonden (demersale) als vrijzwemmende (pelagische) vis in de vooroever door middel van een survey langs de Nederlandse kust. Op basis van deze gegevens gerelateerd aan (a)biotische parameters zou de habitatmodellering verder verfijnd kunnen worden. Vervolgens zouden in de volgende jaren suppleties systematisch worden bemonsterd met een voor/na benadering.

De verwachte resultaten bij aanvang van de geplande meerjarige studie waren:

- Een evaluatie van het bestaan en de grootte van middellangetermijneffecten door cumulatieve fysische veranderingen als gevolg van (herhaald) suppleren op de gemeenschappen van vis en benthos en de kinderkamerhabitat van vis in de vooroever; 
- $\quad$ Een instrumentarium om aan de hand van de relaties tussen kenmerken van suppleties (bv. korrelgrootte, locatie) en gemeenschappen, verwachte effecten van suppleties in het algemeen op gemeenschappen en de kinderkamerhabitat te voorspellen. Dit instrumentarium bestaat uit statistische relaties, waarvoor de onafhankelijke variabelen (de fysische omgevingsfactoren) uit fysische modellen en/of uit waarneming en/of uit scenariostudies kunnen komen.

Om de geschiktheid van een gebied als kinderkamerhabitat te kunnen meten, is het zinvol om metingen te doen aan de directe processen die de kwaliteit bepalen: immigratie, emigratie, groei en sterfte. Vanuit pragmatisch oogpunt is dat echter een intensieve en kostbare aanpak. In het onderzoek is er daarom gekozen om als resultante van die processen de visdichtheid als belangrijkste (response)parameter te gebruiken.

Bij de start van het project is besloten in te zoomen op kustvakken langs de Nederlandse kust die kenmerkend zijn voor de Nederlandse kustregio's: Hollandse kust en Waddenkust. Binnen de kustvakken is gekozen voor een gestratificeerde opzet naar diepte en sediment. De rationale was om binnen de beschikbare tijd het oplossend vermogen van de studie-opzet zo hoog mogelijk te maken en zoveel mogelijk metingen te doen aan de visdichtheid omdat hierin grote variatie werd verwacht. Om het beoogde beeld van de habitatvoorkeuren van de verschillende soorten te krijgen kon op deze manier zowel de biotiek als de abiotiek met een hoge resolutie in kaart gebracht worden.

Voorafgaand aan de kustvakken-opzet is onderzocht op welke manier de verschillende beoogde bemonsteringsmethodes het beste gecombineerd konden worden zodat het logistiek haalbaar was. In 2017 zijn vier kustvakken geselecteerd, die qua diepteprofiel en sediment van elkaar verschillen. De kustvakken zijn tevens geselecteerd op basis van kenmerkende eigenschappen voor een groter deel van de Hollandse kust en Waddenkust en een grote variatie in sedimentsamenstelling binnen het vak. Daarnaast is er rekening gehouden met een verwachte variatie in larvenaanvoer als gevolg van variatie in stromingspatronen langs de Nederlandse kust. In 2018 was er minder vaartijd beschikbaar en is bemonsterd in een kustvak bij Schiermonnikoog.

Gaandeweg het project bleek dat het opvolgen van een geplande vooroeversuppletie niet kon worden uitgevoerd. Daarnaast bleek dat de bemonstering met kleine vaartuigen vanwege de extreme weersgevoeligheid vaak leidde tot uitval. Daardoor is gekozen om in 2019 en 2020 alleen nog maar in te zetten op bodemgebonden vis en het programma om te buigen naar een kustlangse survey op de diepte (3-6 m) waarop in 2017 de meeste vis werd aangetroffen. Daarnaast is in 2019 vanaf maart tot en met juni op drie locaties langs de kust vanaf het strand een bemonstering in de brandingszone uitgevoerd.

In aanvulling op het programma zijn middels een aantal studentonderwerpen meer verdiepende studies uitgevoerd waarbij het functioneren van het gebied is onderzocht aan de hand van dieet en groei. Aanvullend is er ook een modelstudie uitgevoerd waarbij onderzocht is wat de consequenties van verdere klimaatverandering zijn voor het functioneren van de kustzone als opgroeigebied.

Door het bijstellen van het programma zijn ook de verwachtingen met betrekking tot de resultaten bijgesteld. Met het uitgevoerde programma zijn we in staat om:

- Een instrumentarium te leveren waarmee aan de hand van de relaties tussen kenmerken van suppleties (bv. korrelgrootte, locatie) en gemeenschappen, verwachte effecten van suppleties in het algemeen op gemeenschappen en het kinderkamerhabitat voorspeld kunnen worden;

- Inzicht te verschaffen in de ruimtelijke variatie van het functioneren van de vooroever als opgroeigebied voor jonge vis;

- Inzicht te verschaffen in de lange termijnontwikkeling van het gebruik van de vooroever als opgroeigebied in vergelijking met andere gebieden (bv Waddenzee)

- Inzicht te verschaffen in dieet en groei van jonge platvis en ruimtelijke patronen hierin;

- Inzicht te verschaffen in de mogelijke ontwikkelingen in het functioneren van de vooroever als opgroeigebied. 


\subsection{Werkzaamheden}

De aanpak door de jaren is in grote mate gestuurd door de inzetbaarheid van het onderzoeksschip de Luctor. In 2017 was het schip vier werkweken beschikbaar. In 2018 t/m 2020 was er slechts ruimte voor een werkweek per jaar. In 2020 was er uiteindelijk, met name vanwege COVID-19 maatregelen, meer tijd beschikbaar in de aansluitende werkweek. Een herhaling van de uitgebreide bemonstering zoals uitgevoerd in 2017 was financieel echter geen optie in die jaren.

Het in kaart brengen van het functioneren van de ondiepe kustzone voor vis is een uitdagende onderneming. Daarom is in 2016 eerst een pilot uitgevoerd waarbij een aantal methodes en met name de logistieke operatie van het in korte tijd uitvoeren van verschillende metingen (pelagische en demersale vis, abiotiek en benthos) vanaf verschillende platforms (schip, rubberboot en strand) is uitgeprobeerd. Deze pilot waarbij de verschillende methoden simultaan zijn toegepast was erop gericht om ervaring op te doen en aan de hand van deze ervaringen uit te komen op een werkbaar protocol (Couperus e.a., 2016).

In 2017 zijn de gecombineerde methoden toegepast in de vier kustvakken (Tabel 2.1). Op een vergelijkbare manier is in 2018 bij alleen Schiermonnikoog bemonsterd (van Hal, 2018). De keuze voor Schiermonnikoog was gebaseerd op de wens van de opdrachtgever en convenantpartners om te bemonsteren nabij de Waddeneilanden, mede omdat de bemonsteringen in 2017 bij de eilanden niet volledig waren uitgevoerd. Het eerste voorstel was de bemonstering van Ameland te herhalen, maar daar bleek in 2018 een vooroeversuppletie gepland. Daarop is Schiermonnikoog gekozen om aan te sluiten bij eerdere benthosbemonsteringen uitgevoerd in EGS1 (Van Dalfsen e.a., 2014; Damsma e.a., 2017).

In 2019 en 2020 is een kustlangse survey uitgevoerd (Tabel 2.1). Aanvullend is in 2019 op drie locaties vanaf het strand de brandingszone bemonsterd. Deze bemonstering werd deels uitgevoerd met behulp van vrijwilligers. Een aantal van deze vrijwilligers heeft een vergelijkbare bemonstering vanaf het strand bij Egmond aan Zee vanaf juli 2019 voortgezet. In navolging hierop is door WMR in 2020 bij IJmuiden gestart met een strandbemonstering als losstaand project, de gegevens hiervan worden deels gepresenteerd.

Tabel 2.1 Overzicht uitgevoerde werkzaamheden.

\begin{tabular}{|c|c|c|c|c|}
\hline Jaar & Activiteit & Periode & Locaties & Referentie \\
\hline \multirow[t]{2}{*}{2017} & Kustvak-bemonstering & $\begin{array}{l}22-26 \text { aug } \\
12 \text { juni-7 juli }\end{array}$ & $\begin{array}{l}\text { Zuid-Holland, Noord-Holland, } \\
\text { Texel en Ameland }\end{array}$ & Couperus e.a., 2016 \\
\hline & Recente groeisnelheid & & & Rutting, 2017 \\
\hline 2018 & Kustvak-bemonstering & $18-22$ juni & $\begin{array}{l}\text { Schiermonnikoog } \\
\text { Maasvlakte tot Texel }\end{array}$ & $\begin{array}{l}\text { van Hal, } 2018 \\
\text { van Hal en Dijkman- } \\
\text { Dulkes, } 2019\end{array}$ \\
\hline & $\begin{array}{l}\text { Strandbemonstering } \\
\text { Dieet-studies }\end{array}$ & maart-juni & Katwijk, Castricum, Texel & $\begin{array}{l}\text { van der Geest, } 2019 \\
\text { van Berkel, 2020; } \\
\text { Meppelink, 2021 }\end{array}$ \\
\hline \multirow[t]{4}{*}{2020} & $\begin{array}{l}\text { Vervolg strandbemonstering } \\
\text { Kustlangse bemonstering }\end{array}$ & $\begin{array}{l}\text { juli-nov } \\
16-23 \text { juni }\end{array}$ & $\begin{array}{l}\text { Egmond-aan-Zee } \\
\text { IJmuiden t/m Texel + } \\
\text { Waddenzee }\end{array}$ & $\begin{array}{l}\text { Vrooman e.a., } \\
2020 \text { b }\end{array}$ \\
\hline & WMR-Strandbemonstering & maart-sept & IJmuiden & \\
\hline & Vervolg strandbemonstering & jan-nov & Egmond-aan-Zee & \\
\hline & Dagringen & & & Mairo, in prep \\
\hline
\end{tabular}

\subsection{Aanvullende studies}

Het uitgangspunt van de bemonsteringen was dat door het meten van dichtheden een geïntegreerde maat voor alle populatiedynamische processen verkregen werd: immigratie, emigratie, groei en sterfte. Aanvullend hierop zijn aanvullende analyses uitgevoerd en middels studentontwerpen deelprocessen nader bestudeerd. 
- Met behulp van Dynamic Energy Budget (DEB) modellering is geanalyseerd hoe de functie van de vooroever als opgroeigebied zal gaan veranderen onder invloed van klimaatverandering.

- In 2017 is een studie uitgevoerd waarbij de recente groeisnelheid op verschillende plekken gemeten is met behulp van de RNA:DNA-methode (in samenwerking met de vakgroep Animal Breeding and Genomics in Wageningen (Ciotti e.a., 2013a; Rutting, 2017)).

- In 2019/2020 zijn magen verzameld van platvis om te analyseren hoe het dieet door het seizoen heen verandert met behulp van DNA-barcoding (in samenwerking met de vakgroep Marine Animal Ecology in Wageningen (van Berkel, 2020; Meppelink, 2021))

- In 2020 zijn otolieten van juveniele schol verzameld voor de methode ontwikkeling van dagringanalyse. Op basis van dagringaflezingen kan inzicht verkregen worden in het moment van vestigen van schol in de kustzone. Daarnaast biedt deze methode de mogelijkheid de groei per individu te analyseren (Mairo, in prep). 


\section{Soortbeschrijvingen}

De focus van het Natuurlijk Veilig onderzoek was gericht op de demersale vis en dan met name enkele platvissoorten waarvoor de ondiepe kustzone gezien wordt als belangrijke kinderkamer. Daarnaast lag de focus op deze soorten vanwege de verwachte directe link met de abiotische factoren die mogelijk veranderen door suppleties, met name sedimentsamenstelling. Platvissen graven zich in in het zand, en verschillende studies hebben laten zien dat de sedimentsamenstelling daarvoor van belang is. Ook zandspiering graaft zich in, echter om kennis te vergaren over de zandspiering is een ander vistuig en bemonsteringsopzet nodig die binnen Natuurlijk Veilig niet te combineren was met de andere werkzaamheden. Binnen het ecologische onderzoek rondom de pilotsuppletie in de buitendelta van het Amelanderzeegat lag de focus wel op zandspiering (van Hal e.a., 2021) en is een uitgebreidere beschrijving van de zandspieringsoorten gegeven (van Hal, 2018). Een beperkter deel van het Natuurlijke Veilig veldwerk was gericht op pelagische vis, de prioriteit lag hier echter niet op omdat er weinig (directe) effecten van suppleties op deze soorten verwacht werden. In Herman e.a. (2016) werd vertroebeling van de waterkolom als gevolg van suppleties, wat als grootste (directe) risico voor deze soorten wordt gezien, ingeschat als beperkt en van korte duur. Daarbij kwam dat de plannen voor het geschikt maken van het onderzoeksschip om pelagisch te kunnen vissen uiteindelijk niet uitgevoerd konden worden, waardoor pelagische vis alleen met behulp van akoestiek in kaart gebracht kon worden (Couperus e.a., 2020).

Vanwege de focus op de platvis is hieronder uitsluitend een beschrijving gegeven van vier platvissoorten. Dit is echter maar een beperkt deel van de vissoorten die gebruik maken van de kustzone (Bijlage 1).

\subsubsection{Schol}

De Nederlandse kustzone wordt, naast de Waddenzee, gezien als een belangrijke kinderkamer voor de populatie schol in de Noordzee (van Beek e.a., 1989). Om dit opgroeigebied te bereiken moeten de pelagische larven een lange afstand afleggen vanuit de paaiplaatsen die gelegen zijn in o.a. de zuidelijke bocht (voor de kust van Engeland) en in het oostelijke deel van het Kanaal (Barbut e.a., 2019). Schol paait in deze gebieden in de winter en de pelagische eieren werden van december tot maart aangetroffen in de Noordzee (van der Land, 1991; van Damme e.a., 2011), op het NCP werden ze aangetroffen van januari tot nog in juni (van Damme e.a., 2011). De pelagische eieren, en gedurende de ontwikkeling ook de pelagische larven, worden met de dominante stromingen vanuit de paaigebieden meegevoerd naar de kinderkamers (Bolle e.a., 2009; Barbut e.a., 2019). De larven bereiken de kinderkamers doorgaans in het vroege voorjaar (maart - april), waar ze zich na metamorfose, bij een lengte van rond de 10-15 mm vestigen in ondiep water (Zijlstra e.a., 1982; Van der Veer en Bergman, 1986; Pihl, 1989; de Raedemaecker, 2012) of eerst in iets dieper water ( 3 $\mathrm{m}$ ) om vervolgens actief het ondieper water op te zoeken (Edwards en Steele, 1968; Gibson, 1973). Schol die zich in de vooroever vestigt is over het algemeen afkomstig uit de zuidelijke bocht, afhankelijk van de omstandigheden kan een aanzienlijk deel ook afkomstig zijn uit het Kanaal en sporadisch uit meer centraal gelegen paaigebieden voor de kust van Engeland (Barbut e.a., 2019). In de loop van het voorjaar nemen de dichtheden juveniele schol in de opgroeigebieden toe, piekdichtheden worden aangetroffen aan het eind van het voorjaar (mei - juni) waarna de dichtheden weer afnemen (Zijlstra e.a., 1982) door natuurlijke sterfte en later migratie naar dieper water. Algemeen wordt aangenomen dat juveniele schol een voorkeur heeft zich te vestigen in ondiep water gedurende hun eerste groeiseizoen (Gibson, 1973; Zijlstra e.a., 1982; van Beek e.a., 1989; Freitas e.a., 2016). Al lijken ze een iets diepere verspreiding te hebben vergeleken met tarbot en griet (Gibson, 1973; Riley e.a., 1978), maar in het vroege voorjaar concentreren ze zich ook actief in ondiepe poeltje (Berghahn, 1983). In de Waddenzee laat schol in de eerste maand zeer beperkte migratie zien, ze verlaten tijdens laag water de droogvallende platen maar verblijven dan in een ondiep meertje $(\sim 0,5 \mathrm{~m})$ en keren bij hoogwater weer terug, na die eerste maand vertonen ze duidelijkere getijdenmigratie waarbij ze tijdens laag water naar relatief diepere gebieden migreren (Van der Veer en Bergman, 1986). 
Nabij zanderige stranden migreren de jonge platvissen met het tij mee, waarbij schollen tot $4 \mathrm{~cm}$ lengte bij voorkeur rond een diepte van 1-2 m verblijven (Gibson, 1973), 's nachts gaan ze nog iets ondieper dan overdag (Gibson, 1973; Gibson e.a., 1998). Dit dag/nacht patroon is ook geobserveerd in een experimentele opstelling (Burrows, 2001). Verplaatsing van gemerkte juveniele schol liet zien dat ze een duidelijke voorkeur hebben voor een locatie, een aanzienlijk deel keerde na verplaatsing terug naar de locatie waar ze oorspronkelijk gevangen waren (Riley, 1973). In de ondiepe zone verblijven ze in ieder geval de eerste weken tot maanden van hun juveniele levensfase.

Bemonsteringen in de jaren 1978-1982 toonden licht afnemende dichtheden tot $10 \mathrm{~m}$ diepte, met sterker afnemende dichtheden op dieper water (van Beek e.a., 1989). Tijdens de winterperiode migreren jonge schollen naar dieper water verder van de kust af (De Veen, 1978). Naar mate ze groter worden migreren ze naar dieper water (van Keeken e.a., 2007; van Hal e.a., 2016). De 1-jarige schol werd in de historische bemonsteringen tot in het najaar gevangen in de ondiepere gebieden, met name in de Waddenzee (van Beek e.a., 1989). De verblijfsduur in de ondiepe zone is de laatste jaren korter geworden en de 1-jarigen zijn grotendeels uit de ondiepere gebieden verdwenen (van der Veer e.a., 2011; Freitas e.a., 2016). Dit is mogelijk gerelateerd aan de toename van de watertemperatuur (Teal e.a., 2012).

Schol heeft niet een heel uitgesproken sedimentvoorkeur, variërend van zeer fijn zand tot grof zand $(>500 \mu \mathrm{m})$. De larven vestigen zich in gebieden met fijn zand en beperkt slibgehalte (1.5-8\%)

(Zijlstra e.a., 1982). De kleinste juveniele schol heeft vooral een voorkeur voor zeer fijn zand (62-125 $\mu \mathrm{m}$ ) om zich in te graven (Nasir en Poxton, 2001) naarmate ze groeien kiezen ze grover zand tot ongeveer $1 \mathrm{~mm}$ (Gibson en Robb, 2000).

\subsubsection{Tong}

Net als voor schol is de vooroever een belangrijke kinderkamer voor de populatie tong in de Noordzee. De vooroever wordt gezien als het belangrijkste opgroeigebied van tong in Nederlandse kustwateren in vergelijking met de zuidelijke delta en de Waddenzee (van Beek e.a., 1989; Janssen e.a., 2008). Tong paait in het voorjaar waarbij in de maanden april en mei de hoogste dichtheden eieren worden aangetroffen in de paaigebieden; de zuidelijke bocht voor de Belgische kust, het Kanaal en in de Duitse bocht (van der Land, 1991). De paaigebieden van tong liggen dichter bij de kust dan die van schol. Op het NCP werden eieren aangetroffen van april tot augustus, en larven in mei en juni (van Damme e.a., 2011). Vanuit de paaigebieden worden de eieren en larven met de dominante stromingen naar de opgroeigebieden getransporteerd (Bolle e.a., 2005). De larven bereiken de kinderkamers doorgaans aan het einde van het voorjaar (mei - juni), waar ze zich na metamorfose, bij een lengte van 10-12 mm vestigen. Een laboratorium studie liet zien dat de larven die zich vestigen op de bodem een voorkeur hebben voor helderwit sediment ongeacht de korrelgrootte (Champalbert e.a., 1992). Tong die zich in de Nederlandse kustgebieden vestigt is afkomstig uit de paaigebieden in de zuidelijke bocht voor de Belgische kust en het Engelse Kanaal (Barbut e.a., 2019). In de bemonsteringen in de periode van 1970-1987, zat er grote variatie in de precieze locatie van vestigen, met jaarklassen die dominant in het zuiden, midden of noorden van het gebied gevestigd waren (van Beek e.a., 1989). Het belang van de verschillende kinderkamers verschilt daarmee tussen de jaren, maar over het algemeen waren de Duitse bocht, gevolgd door de Nederlandse kustzone en de Waddenzee de belangrijkste gebieden voor 0-groep tong (van Beek e.a., 1989). De kinderkamer van tong beslaat het gebied tot een diepte van $\sim 20 \mathrm{~m}$, al komen ze vooral in hogere dichtheden voor in water minder dan $10 \mathrm{~m}$ diep (van Beek e.a., 1989; Marchand, 1991). Aan de Belgische kust werd tong vooral aangetroffen in sublitorale trekken (in 95\% van de monsters, met gemiddeld 1-14 tong per $1000 \mathrm{~m}^{2}$ ) en in beperktere mate in de brandingszone ( $16 \%$ van de monsters) (Pecceu e.a., 2015).

In de loop van het seizoen nemen de dichtheden juveniele tong in de opgroeigebieden toe, de hoogste dichtheden worden aangetroffen aan het begin van juli waarna de dichtheden weer afnemen door migratie naar diepere wateren (Fonds, 1978; van der Veer e.a., 2001). In tegenstelling tot schol wordt aangenomen dat tong zich in enigszins diepere kustwateren vestigt (van Beek e.a., 1989; Eastwood e.a., 2003), echter er zijn ook studies die een voorkeur voor ondiep water suggereren (Eastwood e.a., 2003; Le Pape e.a., 2003). Echter, bevonden in deze onderzoeksgebieden de slibrijke sedimenten zich grotendeels in het meest ondiepe water (Le Pape e.a. 2003; Rogers, 1992). Slibrijke en fijn zandig sediment heeft de voorkeur voor juveniele tong, maar ook volwassen tong blijkt hier voorkeur voor te hebben (Eastwood e.a., 2003; Le Pape e.a., 2003; Post e.a., 2017). 


\subsubsection{Tarbot en Griet}

Tarbot (Scophthalmus maximus (Linnaeus, 1758)) en griet (Scophthalmus rhombus (Linnaeus, 1758)) zijn platvissoorten, die ondanks hun relatief lage abundantie (van der Hammen e.a., 2013) een hoge commerciële waarde hebben. Het relatief lage aantal volwassenen suggereert dat de habitatbeschikbaarheid voor juveniele stadia de populatiegrootte zou kunnen beperken (Rogers e.a., 1998). Als juveniel lijken de twee soorten erg op elkaar, terwijl naarmate ze groter worden gemakkelijk te onderscheiden zijn. Ondanks hun gelijkaardige uiterlijk is de kennis over de soorten onevenwichtig, met meer informatie over tarbot dan over griet. Ten opzichte van schol en tong is de kennis echter beperkt.

Beide soorten zijn wijd verspreid in de oostelijke Atlantische Oceaan, van IJsland tot Noord-Afrika, inclusief de Middellandse Zee, de Oostzee en de Noordzee. Ze komen voor op zanderige, rotsachtige of gemengde bodems. Voorkeursexperimenten voor tarbot gaven aan dat ze de voorkeur geven aan zandgronden boven grind of gravel (Nasir en Poxton, 2001; Florin en Lavados, 2010), en aan zeer fijn zand $(62-125 \mu \mathrm{m}$ ) boven grotere korrelgroottes (tot $1000 \mu \mathrm{m}$, (Nasir en Poxton, 2001)). Volwassen tarbot wordt meestal gevonden op een dieptebereik van 10-70 m, terwijl volwassen griet iets ondieper leeft (4-73 m, (Kerby e.a., 2013)). Rogers e.a. (1998) geven aan dat ongeveer 50\% van de commerciële vangst binnen een diepte van 20 tot $30 \mathrm{~m}$ werd gevangen. Voor beide soorten wordt gesuggereerd dat ze nogal honkvast zijn (Aneer en Westin, 1990), maar er zijn migraties van de kraamkamers vanaf het zuidoostelijke deel van de Noordzee naar de meer noordelijke gebieden geregistreerd. Gemerkte tarbot uit de Oostzee vertoonde seizoensmigratie (Florin en Franzén, 2010): in de zomer trokken de vissen naar ondieper water om te paaien, terwijl ze in andere periodes in diepere wateren foerageerden. De paaigebieden in de Oostzee waren zelfs ondieper dan verwacht, 5 $\mathrm{m}$ of zelfs minder.

Populatiegenetica (Vandamme e.a., 2014) en larvale distributiemodellering (Barbut e.a., 2019) duiden op het bestaan van meerdere subpopulaties van tarbot en griet. De gegevens suggereren het bestaan van twee subpopulaties van tarbot en griet in de Noordzee. Op basis van de genetische informatie kon een zuidelijke en noordelijke deelpopulatie van de Noordzee worden onderscheiden voor tarbot, met verdere subtiele verschillen binnen de zuidelijke deelpopulatie tussen de zuidelijke Noordzee en de Duitse Bocht (Vandamme e.a., 2014). Voor tarbot werd een populatie in het Kanaal gevonden met een beperkte connectiviteit naar de zuidelijke Noordzee, en een centrale Noordzee-subpopulatie met ook een beperkte connectiviteit naar de subpopulatie van de zuidelijke Noordzee.

Voor griet werd op basis van de larvale connectiviteit (Barbut e.a., 2019) een duidelijke zuidelijke en centrale afgescheiden Noordzee-subpopulatie aangetoond, met een zeer hoge mate van zelfrekrutering.

Beide soorten produceren pelagische eieren, dit gebeurt afhankelijk van de geografische locatie tussen april en augustus (Jones, 1974). De pelagische eieren drijven met de stroming naar de kinderkamers. Tijdens de pelagische fase komen de eieren na ongeveer twee weken uit. De tijd tussen uitkomen en metamorfose varieert naargelang de omgevingstemperatuur, maar zelfs bij een constante temperatuur treedt een grote plasticiteit in ontwikkelingstijd op. Voor tarboteieren uit de Noordzee die in het laboratorium werden gekweekt bij 14-16 ${ }^{\circ} \mathrm{C}$, vond de eerste metamorfose plaats op dag 45, pas op dag 72 vond de laatste metamorfose plaats (Jones, 1973a). Op basis van modelberekeningen is de totale pelagische fase ongeveer 45 dagen voor tarbot en 61 dagen voor griet (Barbut e.a., 2019). In deze tijd legt tarbot ongeveer $102 \mathrm{~km}$ af en griet $140 \mathrm{~km}$ (Barbut e.a., 2019). Tarbot heeft een positief drijvend laat larvaal stadium $(17-26 \mathrm{~mm}$ ) dat vaak wordt aangetroffen in de hyponeustale laag (Last, 1979). Als gevolg hiervan wordt hun verspreiding naar de kinderkamers waarschijnlijk sterk beïnvloed door de windomstandigheden (Riley, 1981; Haynes e.a., 2014). Dit, in combinatie met andere effecten tijdens transport, zou kunnen leiden tot jaarlijkse variatie in abundantie tussen stranden (Nissling e.a., 2006; Haynes e.a., 2011). Met afmetingen tussen de 2 en 3,5 cm totale lengte, metamorfoseren ze en nestelen zich op de bodem in ondiep water dicht bij het strand. Het tijdstip van vestiging varieert ruimtelijk en ligt tussen maart en oktober. In Borth, Cardiganshire, Wales, verscheen van juli tot oktober nieuw gevestigde tarbot (Jones, 1973b), terwijl in het Kattegat de eerste verschijning werd waargenomen in augustus (Pihl, 1989). Aan de Ierse westkust vestigde griet zich tussen maart en juni (Haynes e.a., 2014). 
0-groep tarbot langs de Britse kust werd alleen gevonden in wateren $<2 \mathrm{~m}$ diepte, terwijl 0-groep griet werd gevonden in wateren < 4 m (Riley, 1981; Wyche en Shackley, 1986; Pihl, 1989). Op een diepte van ongeveer 1 meter was tarbot de dominante soort (Jones, 1973b). In de Oostzee werd de 0groep van beide soorten ook tot op $1 \mathrm{~m}$ diepte aangetroffen (Molander, 1923, Molander, 1964 in Florin en Franzén (2010)), vergelijkbaar in het Kattegat (Pihl, 1989). De juvenielen van beide soorten werden voornamelijk aangetroffen op onbeschutte stranden met grof zand (Riley, 1981; van der Hammen e.a., 2013), terwijl langs de Ierse kust de grootste aantallen werden gevonden op beschutte stranden (Haynes e.a., 2010) en ook in de Oostzee was er een voorkeur voor beschutte stranden (Florin en Lavados, 2010). Juvenielen blijven 1-2 jaar in de kinderkamer, voordat ze naar diepere wateren gaan en rekruteren voor het volwassen bestand (Haynes e.a., 2014). Binnen deze periode vertonen ze enige seizoensmigratie uit de brandingszone (Pihl, 1989). De migratie van vrijgelaten gekweekte 1-jarige tarbot in de Oostzee was echter minder dan $10 \mathrm{~km}$ en ze bleven dicht bij de kust gedurende de eerste 2 jaar na het uitzetten (Støttrup e.a., 2002). In de brandingszone langs de Belgische kust werd in ieder geval in mei-december tarbot aangetroffen, waar griet in mei afwezig was (Beyst e.a., 1999). Daarentegen, ook gebaseerd op andere gegevens van de Belgische brandingszone, werd tarbot pas in september aangetroffen, terwijl griet gedurende een langere periode van mei tot december in slechts één van de twee bemonsteringsjaren werd aangetroffen (Beyst e.a., 2001). In een iets latere studie (2013-2014) in het kader van een impactstudie vanwege het aanleggen van een strand- en vooroeversuppletie bij Mariakerke, ten zuiden van Oostende, werden tarbot/griet in de brandingszone aangetroffen in $66 \%$ van de $242 \mathrm{~m}$ boomkormonsters $(400 \mathrm{~m})$ genomen tussen twee strandhoofden (Colson e.a., 2016). Met name in september/oktober werden tarbot/griet gevangen met 1-7 tarbot/griet per $1000 \mathrm{~m}^{2}$. Er was grote variatie tussen de trekken en periodes. In het impactgebied was er een lichte stijging te zien in de dichtheden na de vooroeversuppletie. Met deze dichtheden was tarbot/griet een van de dominantste soorten die in iedere geval in de meeste monsters werd aangetroffen. In het iets diepere, sublitorale, deel behoorde tarbot/griet niet tot de 10 meest aangetroffen soorten (Pecceu e.a., 2015).

In de meeste andere onderzoeken is de abundantie van juvenielen ook laag (Beyst e.a., 2002; Haynes e.a., 2014; Olds e.a., 2018). In het Kattegat varieerden de dichtheden van de 0- en 1-groep van 0,1 tot 3 individuen per $1000 \mathrm{~m}^{2}$ (Pihl, 1989). De gemiddelde dichtheid van $0+$ tarbot langs de Ierse kust varieerde van $0,1( \pm 0,3)$ tot $18,5( \pm 6,9)$ individuen per $1000 \mathrm{~m} 2$ (Haynes e.a., 2010). Voor de kust van Litouwen werden tarbotdichtheden waargenomen van 0 tot 23 individuen per $1000 \mathrm{~m} 2$ (Stankus, 2003) en 4,9 individuen per $1000 \mathrm{~m}^{2}$ werden geregistreerd voor de kust van Wales (Jones, 1973b).

In de Nederlandse wateren is de vangst van jonge tarbot en griet beperkt. Gedeeltelijk wordt dit veroorzaakt door beperkte bemonsteringen in de ondiepe kustwateren, die als hun belangrijkste habitat worden beschouwd, en beperkte bemonsteringen in het hoofdseizoen dat ze aanwezig zijn. Voor de Nederlandse brandingszone wordt informatie verstrekt door de NJN strandwerkgroep, en de historische RIVO data gerapporteerd in Teal en van Keeken (2011). Voor andere ondiepe gebieden zoals de Waddenzee (De Vlas, 1979; Vrooman e.a., 2020a) of de Schelde-delta (Wolff e.a., 1981) worden sporadische meldingen van de aanwezigheid van lage aantallen gerapporteerd. In de iets diepere wateren, de geulen, getijdengeulen en de kustwateren met een diepte van 5-10 m, zijn er gegevens van tarbot en griet gepresenteerd op basis van de Demersal Fish Survey (DFS) (Tulp e.a., 2008). De DFS-trends laten zien dat beide soorten (het merendeel zijn jonge exemplaren van 0-2 jaar) in lage aantallen voorkomen in de Waddenzee, Kustzone en Westerschelde, met een lichte toename in aantallen over de tijd. 


\section{$4 \quad$ Historische bemonsteringen}

\subsection{Introductie}

Om recente gegevens te kunnen duiden is een inventarisatie gemaakt van visgegevens uit historische bemonsteringen in de vooroever (Tabel 4.1). Waar nodig zijn deze gegevens gedigitaliseerd op basis van het papieren WMR-archief en in enkele gevallen gecorrigeerd. Een deel van deze gegevens is ontsloten voor algemeen gebruik via Informatiehuis Marien (IHM) en Waterinfo Extra (WIE).

Tabel 4.1 Programma's waarvan de gegevens zijn gecompileerd en gebruikt.

\begin{tabular}{|c|c|c|c|c|c|}
\hline Programma & Jaren & Periode & Tuig & Opslag/Ontsluiting & Referentie \\
\hline Strandbemonstering & $1974-1985$ & Gehele jaar & $\begin{array}{l}73 \text { trekken met duwnet; } \\
542 \text { trekken met } 2 \text { m boomkor van } \\
\text { rubberboot/onderzoeksschepen } \\
\text { krab/Stern }\end{array}$ & $\begin{array}{l}\text { Opslag: WMR FRISBE } \\
\text { database; Ontsluiting: } \\
\text { Natuurlijk Veilig programma: } \\
\text { IHM en WIE. }\end{array}$ & $\begin{array}{l}\text { Teal en van Keeken } \\
\text { (2011) }\end{array}$ \\
\hline Strandbemonstering & 2011 & Juli & $\begin{array}{l}54 \text { trekken } 2 \mathrm{~m} \text { boomkor vanaf } \\
\text { rubberboot }\end{array}$ & $\begin{array}{l}\text { Opslag: WMR FRISBE } \\
\text { database; Ontsluiting: } \\
\text { Natuurlijk Veilig programma: } \\
\text { IHM en WIE. }\end{array}$ & (van Keeken, 2011) \\
\hline $\begin{array}{l}\text { Demersale Fish } \\
\text { Survey (DFS) }\end{array}$ & $1970-1986$ & Voorjaar & 3m-boomkor 2-40m diepte & WMR FRISBE & (van Beek e.a., 1989) \\
\hline $\begin{array}{l}\text { Sole Net Survey } \\
\text { (SNS) }\end{array}$ & 1969-nu & Najaar & 3m-boomkor & ICES datras database & $\begin{array}{l}\text { (van Keeken e.a., } \\
\text { 2005) }\end{array}$ \\
\hline
\end{tabular}

Historische gegevens van de strandbemonsteringen in 1974-1985 waren al gedigitaliseerd. Vanuit Natuurlijk Veilig is er een beperkt aantal trekken toegevoegd en zijn er correcties uitgevoerd. Van deze bemonsteringen is er zover wij hebben kunnen vinden geen werkplan of werkbeschrijving noch is er gerapporteerd over de resultaten, op een enkele verwijzing na (van Leeuwen en Rijnsdorp, 1986). Op basis van mondelinge communicatie van (oud)-medewerkers blijkt een groot deel van de bemonsteringen opportunistisch te zijn uitgevoerd. Goede weersomstandigheden, beschikbaarheid rubberboot of schip, en beschikbaarheid van stagiaires vormden de randvoorwaarden. In de meeste jaren was het daardoor geen consistent opgezette bemonstering. Daarnaast betrof een deel experimenten, bijv. het gebruik van verschillende maaswijdtes, dit is echter niet duidelijk gedocumenteerd en daarmee niet meer te reconstrueren. Er moet dus voorzichtig omgegaan worden met interpretaties op de volledige dataset.

De DFS en SNS surveys zijn Wettelijke OnderzoeksTaken (WOT) waarvan de najaarsgegevens worden gebruikt voor de jaarlijkse bestandschattingen uitgevoerd door de International Council for Exploration of the Sea (ICES). De DFS wordt uitgevoerd in de Waddenzee, Scheldes en Kustzone, in de kustzone is het merendeel van de vistrekken uitgevoerd in water dieper dan $5 \mathrm{~m}$. De SNS wordt uitgevoerd op vastliggende transecten parallel aan de kust en een deel loodrecht op de kust van ondiep naar dieper water. In de beginjaren zijn de DFS en SNS ook uitgevoerd in het voorjaar. Deze gegevens worden niet gebruikt in de bestandschattingen en zijn nog niet volledig gedigitaliseerd. Voor Natuurlijk Veilig is wel een stap gemaakt met de digitalisatie. Het gaat hierbij met name om voorjaarsgegevens van de DFS uitgevoerd in de Waddenzee. De gedigitaliseerde gegevens zijn beschikbaar in de WMR FRISBEdatabase, maar nog niet ontsloten voor een breder publiek.

Naast deze datasets is er in enkele analyses gebruik gemaakt van gegevens uit de WMR FRISBEdatabase van andere projecten uitgevoerd in de kustzone. Hieronder vallen onder andere gegevens uit de Voordelta in het kader van de compensatiemaatregelen voor de aanleg van de tweede Maasvlakte (Tulp e.a., 2016a) en de bemonsteringen in het kader van de Zandmotor (van Hal, 2013). 


\subsection{Historische gegevens gebruikt in de analyse}

Aangezien de historische strandbemonstering niet consistent zijn uitgevoerd, is er een selectie gemaakt waarin uitsluitend de gegevens van de jaren 1981-1983 voor de locaties Egmond aan Zee, Wijk aan Zee, IJmuiden en Noordwijk zijn gebruikt. Gedurende deze jaren zijn alle vier de locaties redelijk consistent door het jaar heen bemonsterd en zijn per locatie verschillende dieptes bemonsterd gedurende een bemonsteringsdag. Dit resulteerde in 245 vistrekken verdeeld over een dieptebereik van 0 tot $10 \mathrm{~m}$ uitgevoerd van een rubberboot met een $2 \mathrm{~m}$ boomkor. Met behulp van een hodometer is het aantal omwentelingen per vistrek geregistreerd, het aantal omwentelingen is volgens een omrekeningsfactor $(3,6)$ omgerekend naar afgelegde afstand. De vangsten zijn vervolgens opgewerkt naar dichtheden juveniele vis (aantal per hectare) per seizoen en per diepteklasse, hierbij is niet gecorrigeerd voor vangst- en/of tuigefficiëntie. Naast de bemonstering met de $2 \mathrm{~m}$ boomkor zijn er 45 vistrekken met een duwnet uitgevoerd verdeeld over de vier eerdergenoemde locaties en jaren.

In aanvulling hierop zijn gegevens van de DFS gebruikt. Van de voorjaars DFS (april-mei) zijn van de Hollandse en Waddenkust gegevens beschikbaar voor de jaren 1978, 1980-1983 en 1985 . In totaal zijn 273 vistrekken uitgevoerd verdeeld over een dieptegradiënt ( $2-24 \mathrm{~m}$ ). Vangsten zijn opgewerkt naar dichtheden juveniele vis (aantal per hectare) per diepteklassen. De DFS-najaarsgegevens (september - november) van de Hollandse kust en Waddenkust voor de jaren 1978 - 1985 zijn op dezelfde wijze opgewerkt. In totaal zijn 667 vistrekken uitgevoerd waarbij het merendeel is uitgevoerd in wateren dieper dan $10 \mathrm{~m}$. Op basis van deze gegevens is een analyse uitgevoerd naar de verspreiding van vis in de vooroever in beide seizoenen gedurende de desbetreffende jaren.

Om te bepalen hoe de soorten gebruik maken van de verschillende dieptes in de vooroever, zijn de vangstgegevens ingedeeld in drie diepteklassen: 0-2 m, 2-5, en 5-10 m. Het verschil in dieptegebruik is statistisch getest (Bijlage 4).

\subsection{Resultaten historische gegevens}

\subsubsection{Schol}

Juveniele schol werd het gehele jaar door gevangen over het dieptebereik van 0 tot $10 \mathrm{~m}$, wel is er een verschil te zien tussen 0 - en I-groep schol. 0- en I-groep schol zijn per maand op basis van de lentefrequentieverdeling onderscheiden. Er was grote variatie in de dichtheden schol in de vangsten van de strandbemonstering (Figuur 4.1, Figuur 4.2). In het voorjaar (maart - mei) werd 0-groep schol in beperkte aantallen aangetroffen, indien aangetroffen was dit vrijwel uitsluitend in het meest ondiepe water (Figuur 4.1). De nieuwe aanwas schol werd voor het eerst in grote aantallen gevangen in juni (zomer) waarbij geen duidelijke dieptegradiënt werd waargenomen. De aankomst van 0-groep schol in mei, en in grotere aantallen in juni, werd ook waargenomen met het duwnet.
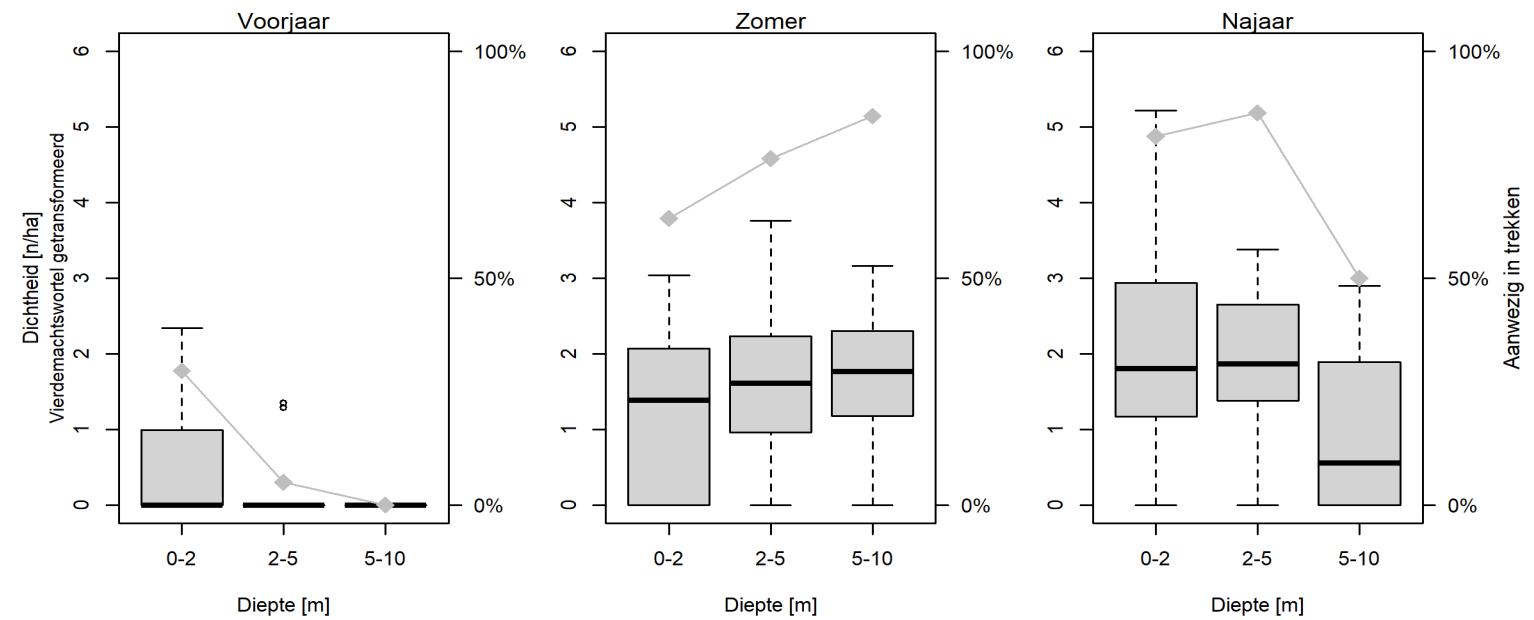

Figuur 4.1. Dichtheid 0-groep schol (vierdemachtswortel getransformeerde dichtheid [aantal per hectare]) in de strandbemonstering (1981-1983) nabij Egmond aan Zee, Wijk aan Zee, IJmuiden en Noordwijk. Dichtheid per diepteklasse $(0-2 ; 2-5 ; 5-10 \mathrm{~m})$ is weergeven met boxplots; De grijze lijnen geven het percentage van de vangsten met minimaal één schol. 
In het najaar waren de dichtheden van 0-groep schol hoger in de ondiepste diepteklassen dan vergeleken met de diepere zone $(5-10 \mathrm{~m})$. Eenjarige schol werd in het voorjaar in de hoogste dichtheden aangetroffen waarna de dichtheden in de loop van het jaar afnamen (Figuur 4.2).

In het najaar werd slecht een enkele I-groep schol aangetroffen. De I-groep schol leek geen voorkeur te hebben voor een bepaalde dieptezone, ze werden verspreid over de vooroever in vergelijkbare dichtheden gevangen.
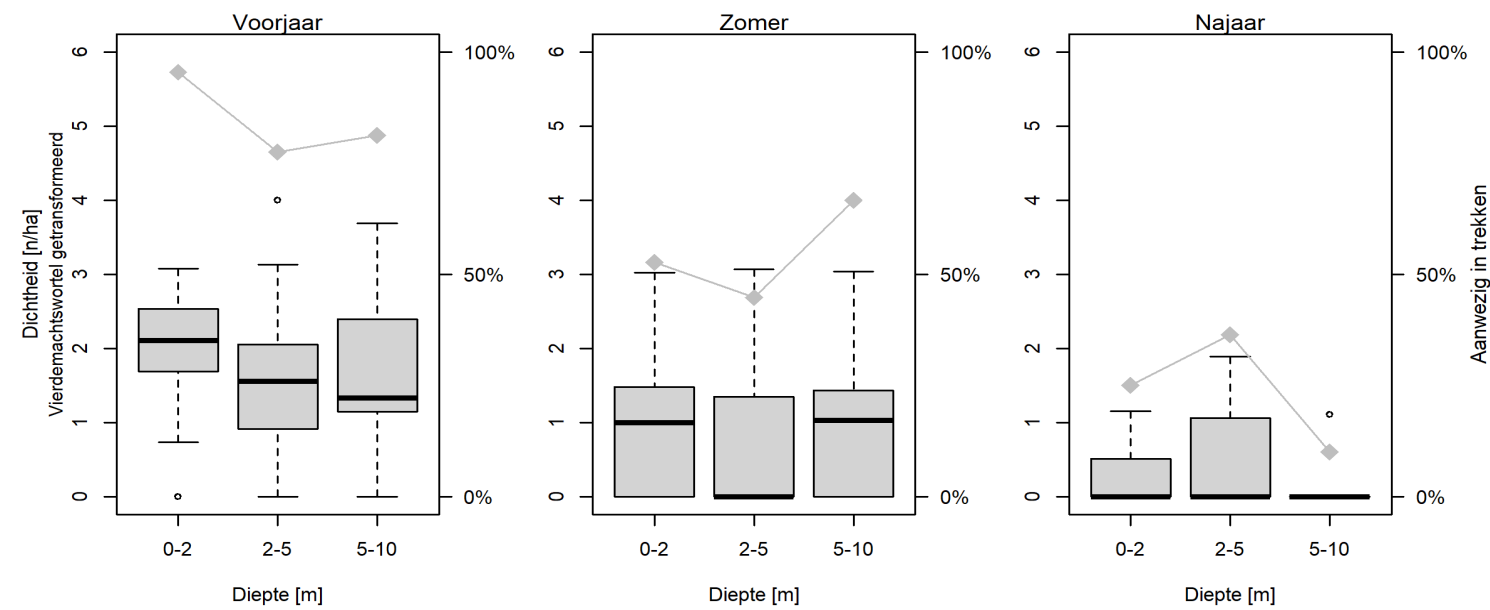

Figuur 4.2. Dichtheid I-groep schol (vierdemachtswortel getransformeerde dichtheid [aantal per hectare]) in de strandbemonstering (1981-1983) nabij Egmond aan Zee, Wijk aan Zee, IJmuiden en Noordwijk. Dichtheid per diepteklasse $(0-2 ; 2-5 ; 5-10 \mathrm{~m})$ is weergeven met boxplots; De grijze lijnen geven het percentage van de vangsten met minimaal één schol.

In de meerderheid van de vistrekken werd op zijn minst één juveniele schol (0- of I-groep) gevangen, het aandeel 0- en I-groep schol verschuift over het jaar. De resultaten uit de historische strandbemonstering laten zien dat juveniele schol de gehele vooroever (0-10 m diepte) gebruikte.

De resultaten uit de historische DFS (voorjaar en najaar) sluiten enigszins aan op de resultaten uit de historische strandbemonstering. Tijdens de voorjaars DFS werd nog geen 0-groep schol gevangen, hierdoor is de diepteverspreiding een afspiegeling van de I-groep schol. In zowel het voorjaar als in het najaar waren de waargenomen dichtheden juveniele schol het hoogst in de diepteklasse 2-5 m, waarbij de laagste dichtheden werden waargenomen in het diepste water (Figuur 4.3).
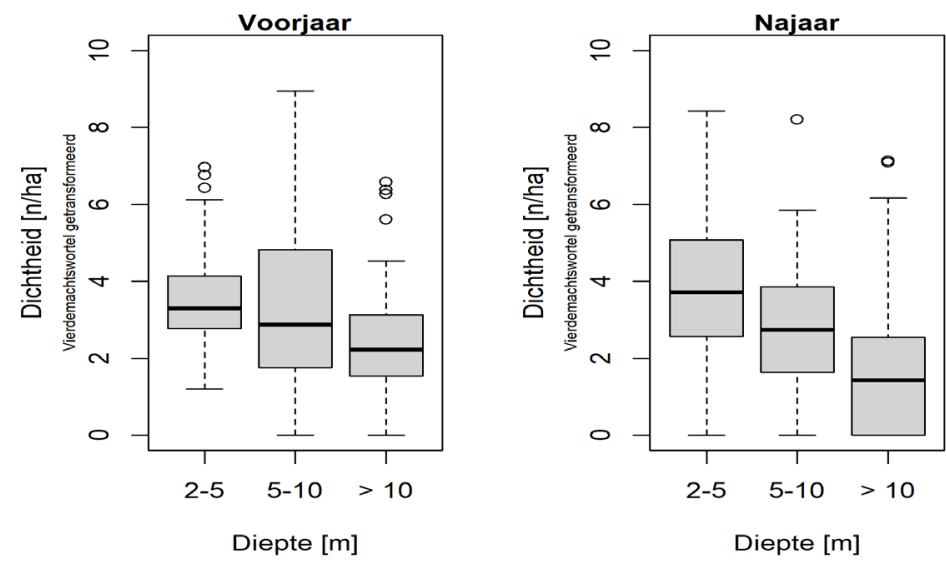

Figuur 4.3. Dichtheid juveniele schol (vierdemachtswortel getransformeerde dichtheid [aantal per hectare]) in de periode 1978 - 1985 tijdens de voor- en najaars-DFS in de Hollandse- en Waddenkust, per diepteklasse (2-5; 5-10; >10 m).

\subsubsection{Tong}

Juveniele tong werd het gehele jaar gevangen in de relatief diepere zone van de vooroever, hierin is geen verschil te zien tussen 0- en I-groep (Figuur 4.4, Figuur 4.4), onderscheiden op basis van de lengtefrequentieverdeling. In het voorjaar werd geen 0 -groep tong gevangen, de I-groep werd vooral in de diepere zones (Figuur 4.4) gevangen. Eenjarige tong werd in de zomer nog maar in lage 
aantallen aangetroffen en in het najaar helemaal niet meer gevangen. De nieuwe aanwas werd voor het eerst in juli gevangen, met iets hogere dichtheden in de 2-5 m zone. In het najaar waren de dichtheden 0-groep tong in dezelfde orde van grootte als in de zomer, echter hadden ze in het najaar op basis van de dichtheden een diepere verspreiding. Het aandeel van de vistrekken waarin op zijn minst één juveniele tong werd waargenomen was aanzienlijk lager in de brandingszone dan in dieper water. Met het duwnet, waarin enkel in het ondiepste water werd gevist, werd zelfs helemaal geen juveniele tong gevangen. De resultaten impliceren dat juveniele tong een voorkeur had om zich te vestigen in water vanaf $2 \mathrm{~m}$ diep en dat de vooroever het gehele jaar door gebruikt werd om op te groeien.
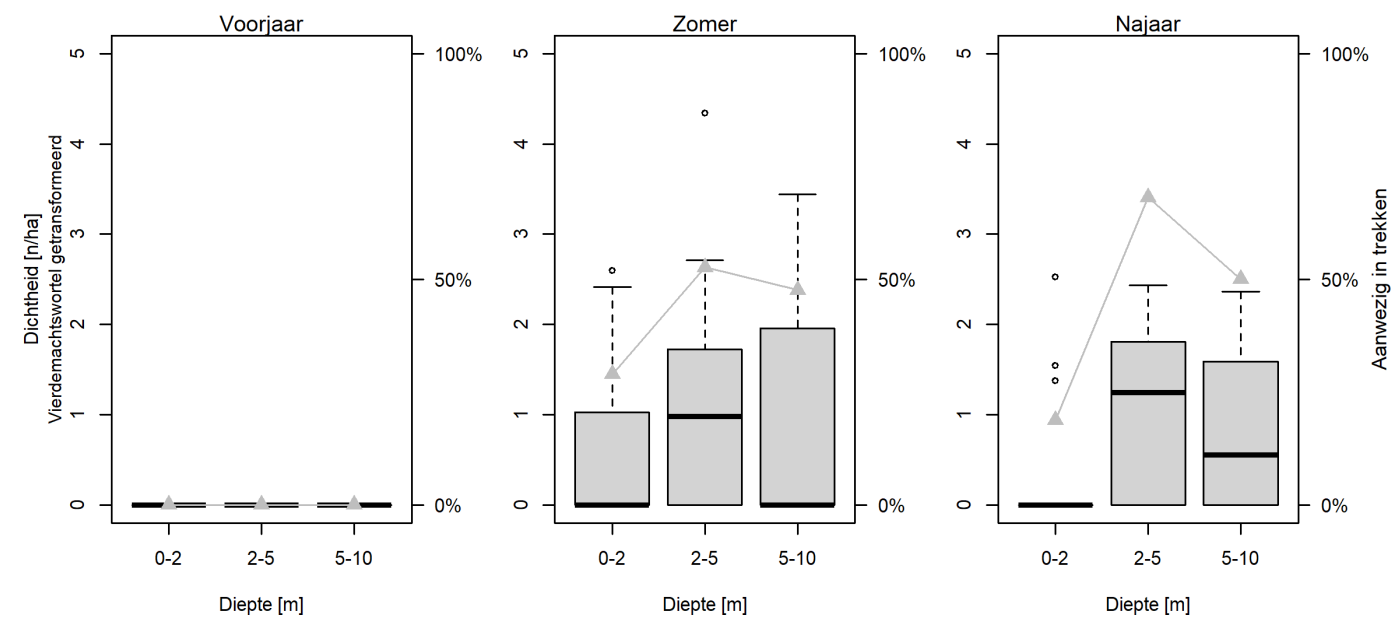

Figuur 4.4 Dichtheid 0-groep tong (vierdemachtswortel getransformeerde dichtheid [aantal per hectare]) in de strandbemonstering (1981-1983) nabij Egmond aan Zee, Wijk aan Zee, IJmuiden en Noordwijk. Dichtheid per diepteklasse $(0-2 ; 2-5 ; 5-10 \mathrm{~m})$ is weergeven met boxplots; De grijze lijnen geven het percentage van de vangsten met minimaal één tong.
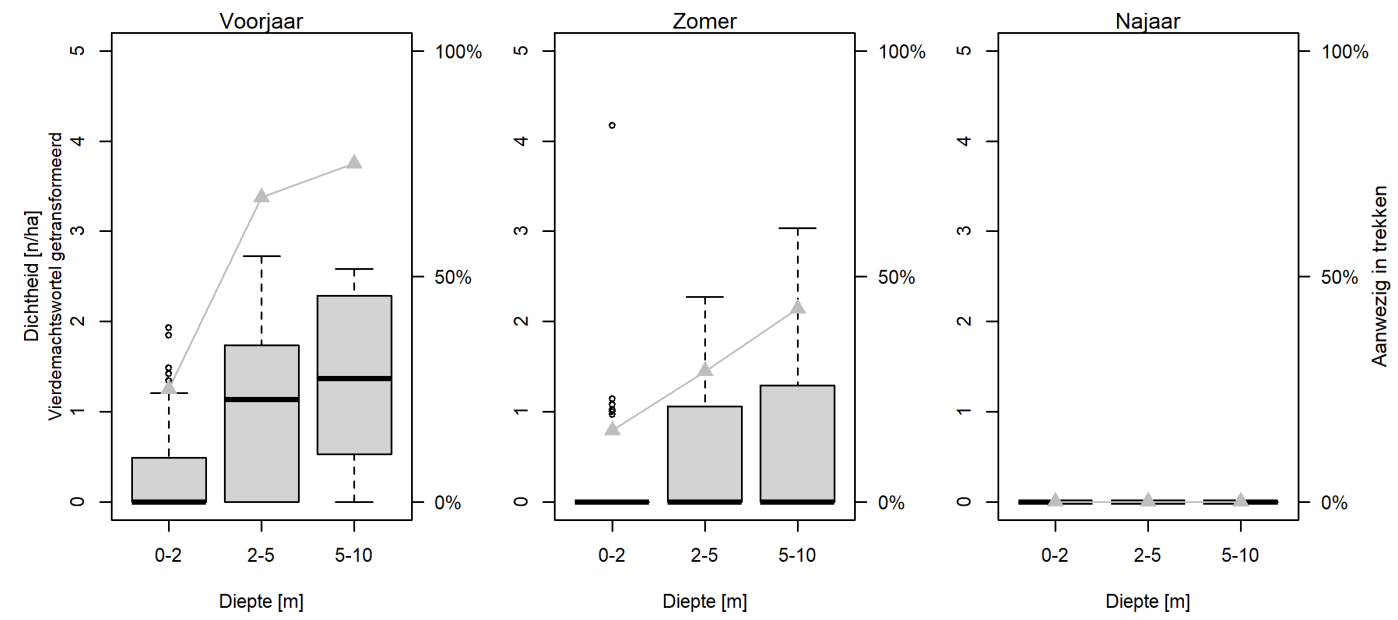

Figuur 4.5 Dichtheid I-groep tong (vierdemachtswortel getransformeerde dichtheid [aantal per hectare]) in de strandbemonstering (1981-1983) nabij Egmond aan Zee, Wijk aan Zee, IJmuiden en Noordwijk. Dichtheid per diepteklasse $(0-2 ; 2-5 ; 5-10 \mathrm{~m})$ is weergeven met boxplots; De grijze lijnen geven het percentage van de vangsten met minimaal één tong.

Ook gedurende de voorjaars DFS werd nog geen 0-groep tong gevangen, hierdoor is de diepteverspreiding een afspiegeling van de I-groep over de vooroever. In het voorjaar werden de hoogste dichtheden juveniele tong waargenomen in de diepteklassen 2-5 $\mathrm{m}$, dichtheden in de diepere zones waren nagenoeg gelijk (Figuur 4.6). In het najaar waren de waargenomen dichtheden juveniele tong hoger dan in het voorjaar. Juveniele tong kwam in het najaar in alle dieptezones voor, waarbij de laagste dichtheden voorkwamen in de diepste zone (> $10 \mathrm{~m})$. 

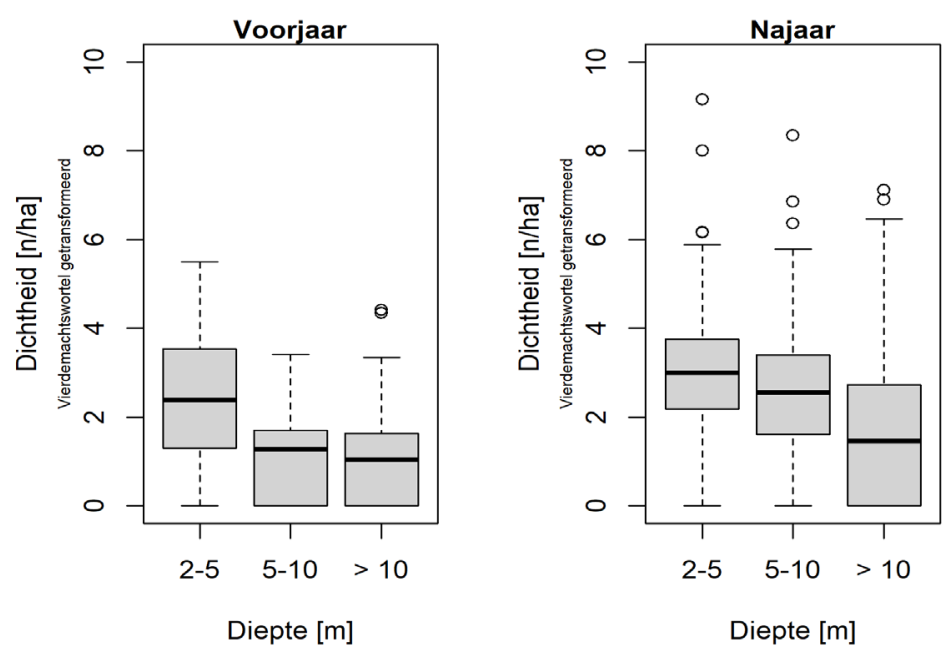

Figuur 4.6. Dichtheid juveniele tong (vierdemachtswortel getransformeerde dichtheid [aantal per hectare]) in de jaren 1978 - 1985 tijdens de voor- en najaars-DFS in de Hollandse- en Waddenkust, per diepteklasse (2-5; 5-10; >10 m).

\subsubsection{Tarbot}

Lage dichtheden juveniele tarbot zijn door het seizoen alleen in het meest ondiepe deel van de vooroever gevangen. De meeste juveniele tarbot werden zowel in het voorjaar, de zomer als het najaar vrijwel uitsluitend in de brandingszone aangetroffen (0-2 m) (Figuur 5.9). Een duidelijke aankomst van 0-groep tarbot kon niet worden waargenomen, omdat tarbot kleiner dan $5 \mathrm{~cm}(0-$ groep) van maart tot en met oktober gevangen werd en vanwege de lage dichtheden. Ook in de vangsten met het duwnet werd tarbot van $5 \mathrm{~cm}$ verdeeld over het jaar gevangen. De hogere waargenomen dichtheid in de brandingszone in het najaar doet vermoeden dat de meeste 0-groep tarbot in de loop van de zomer aankomt. Ook de frequentie van voorkomen in de vistrekken wees op een duidelijke voorkeur voor de brandingszone. In de diepere zones werd op nagenoeg geen enkel station een tarbot gevangen (Figuur 4.7). Ook in de DFS werden de hoogste dichtheden aangetroffen in de vistrekken uitgevoerd in het ondiepste water, dit gold voor zowel het voorjaar als het najaar. In water van $5 \mathrm{~m}$ of dieper werd nagenoeg geen juveniele tarbot aangetroffen.
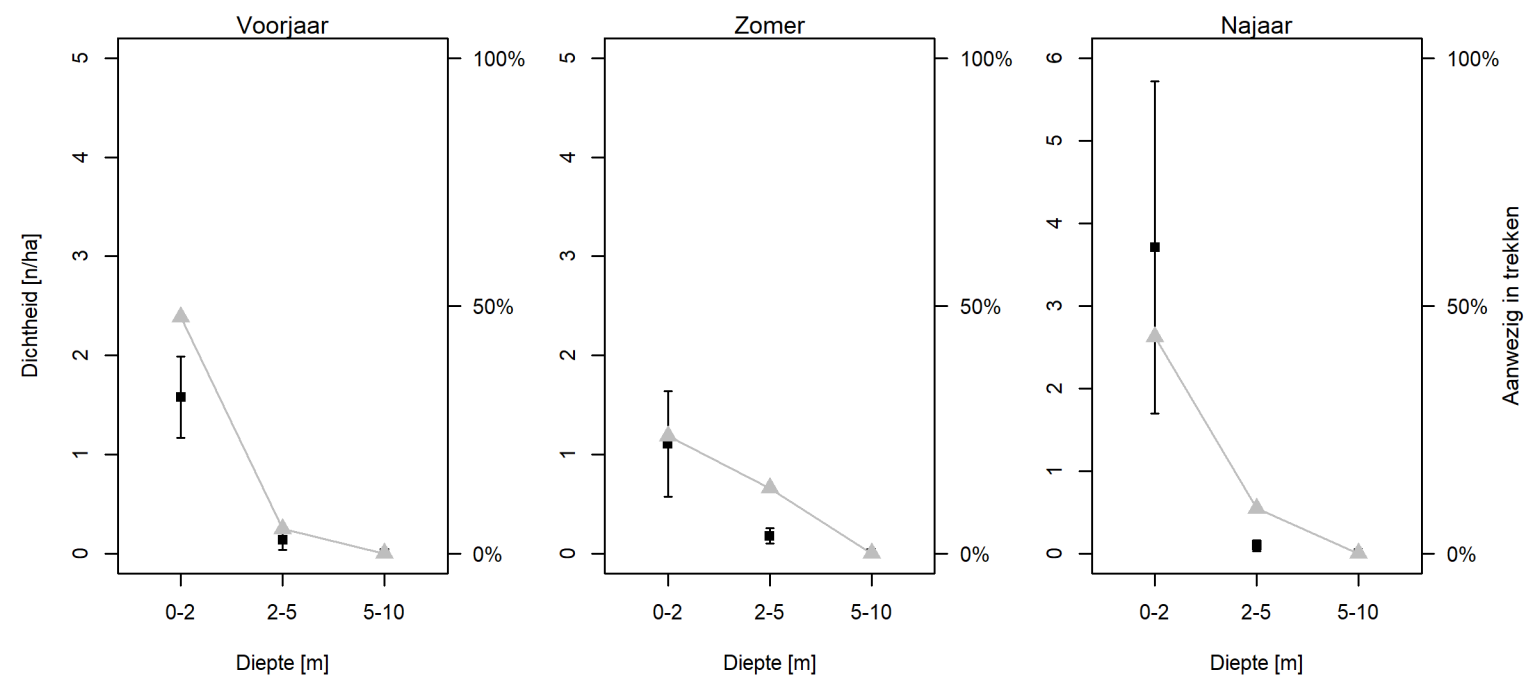

Figuur 4.7. Gemiddelde dichtheid tarbot (aantal per hectare) in de jaren 1981-1983 tijdens de strandbemonstering nabij Egmond aan Zee, Wijk aan Zee, IJmuiden en Noordwijk. Gemiddelde dichtheid over de diepteklassen $(0-2 ; 2-5 ; 5-10 \mathrm{~m}$ ) in zwarte vierkanten (incl. standard error), in grijs het percentage van de vangsten waarin op zijn minst één tarbot aanwezig was.

\subsubsection{Griet}

Juveniele griet werd gedurende het hele seizoen in zeer lage dichtheden aangetroffen, en uitsluitend in het ondiepste deel van de vooroever. In voor- en najaar is de meeste juveniele griet aangetroffen in 
de brandingszone (0-2 $\mathrm{m}$ ), terwijl in de zomer de hoogste aantallen voorkwamen bij een diepte van 2$5 \mathrm{~m}$ (Figuur 4.8). De kleinste griet ( $<5 \mathrm{~cm}, 0$-groep) werd vrijwel uitsluitend gevangen in de zomermaanden, dit doet vermoeden dat griet zich dan vestigt in de opgroeigebieden. Met het duwnet werd griet enkel in het najaar gevangen met een lengte variërend van $5-7 \mathrm{~cm}$. De aanwezigheid van griet in de vangsten impliceert dat ook griet een voorkeur voor de brandingszone heeft, alhoewel in iets mindere mate in vergelijking met tarbot. Het aandeel van de vistrekken waarin op zijn minst één griet werd waargenomen was beduidend hoger in de brandingszone dan in diepere wateren, in het voorjaar en het najaar werd in geen enkele vistrek in water van 5-10 m waargenomen (Figuur 4.8). Ook in de DFS werden zowel in het voor- als najaar de hoogste dichtheden aangetroffen in de brandingszone, en was de gemiddelde dichtheid het hoogst in het najaar. In water van $5 \mathrm{~m}$ of dieper werd nagenoeg geen juveniele griet aangetroffen.
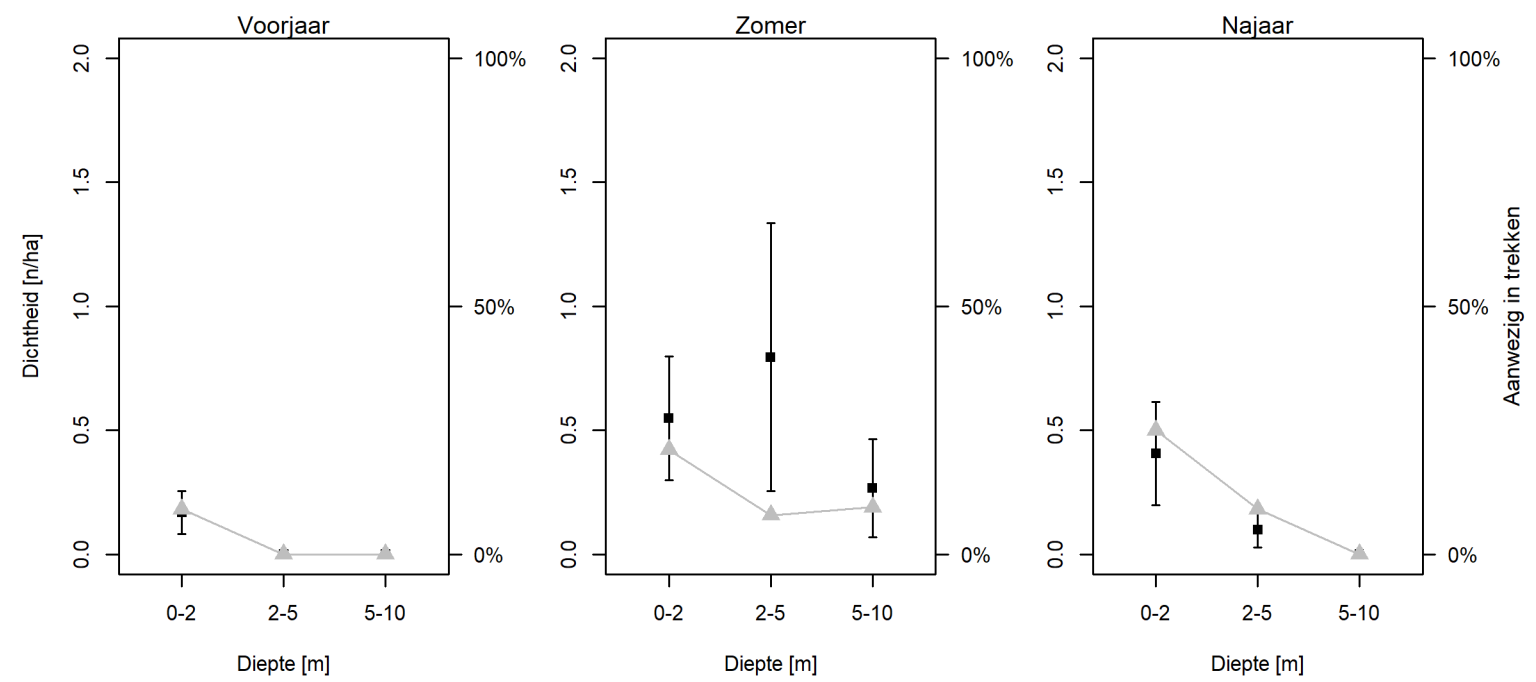

Figuur 4.8. Gemiddelde dichtheid griet (aantal per hectare) in de jaren 1981-1983 tijdens de strandbemonstering nabij Egmond aan Zee, Wijk aan Zee, IJmuiden en Noordwijk. Gemiddelde dichtheid over de diepteklassen $(0-2 ; 2-5 ; 5-10 \mathrm{~m})$ in zwarte vierkanten (incl. standard error), in grijs het percentage van de vangsten waarin op zijn minst één griet aanwezig was.

\subsubsection{Overige soorten}

Andere demersale soorten (Bijlage 1) die in hoge dichtheden werden gevangen in de historische strandbemonstering waren schar en grondel (Pomatoschistus sp.) Beide werden in hogere aantallen gevangen dan schol. Schar werd in de hoogste dichtheden aangetroffen in de diepteklassen 5-10 m, met afnemende waterdiepte namen de dichtheden schar af. Grondels werden wijdverspreid over de vooroever aangetroffen. Een soort die enigszins verrassend maar in een beperkt aantal monsters werd aangetroffen was zandspiering.

Ook in de voorjaars-DFS werden schar en grondel in hoge dichtheden aangetroffen. Andere veel voorkomende soorten waren gewone pitvis (Callionymus lyra) en wijting (Merlangius merlangus). Pitvis was in de voorjaars-DFS zelfs abundanter dan grondel.

Van de pelagische soorten waren sprot en haring veruit het meest voorkomend in de vangsten van zowel de historische strandbemonstering als de voorjaars-DFS, hierbij waren de aantallen sprot beduidend hoger dan die van haring. 


\subsection{Discussie \& conclusie}

De opzet van de historische strandbemonstering was weliswaar opportuun, omstandigheden moesten voldoen aan bepaalde randvoorwaarden, desondanks is er gedurende de geselecteerde jaren (19811983) behoorlijk consistent door het jaar heen gevist op de verschillende onderzoeklocaties. Hierdoor is het aantal vistrekken dat is uitgevoerd per seizoen en per diepteklasse redelijk gelijk verdeeld. De Igroep van schol en tong werd in afnemende dichtheden over het seizoen gevangen. De I-groep tong werd in het najaar helemaal niet meer gevangen. De afnemende dichtheden van I-groep schol en tong kan het gevolg zijn van een verschuiving naar dieper water. Aannemelijker is echter dat de vangstefficiëntie van het gebruikte tuig met de toenemende lengtes door het seizoen heen afnam en deze leeftijdsgroep nog steeds aanwezig was in de vooroever. Naarmate (plat)vis groter wordt zijn ze beter in staat weg te zwemmen van het vistuig, hierdoor was de vangstefficiëntie van de I-groep schol en tong in de zomer en zeker het najaar zeer waarschijnlijk laag (Bijlage 9). De lage vangsten van tarbot en griet houden waarschijnlijk ook verband met hun hoge zwemsnelheid.

De historische voorjaarsbemonstering in de Nederlandse kustzone is uitgevoerd met een boomkor met $20 \mathrm{~mm}$ (gestrekte) maaswijdte. Deze maaswijdte is niet echt geschikt voor het vangen van 0-groep schol in de eerste weken tot maanden. Het is daardoor in lijn met de verwachtingen dat 0-groep schol in maanden april en mei nauwelijks is aangetroffen in de monsters. Pas in juni bereikt schol de maat waarbij ze achterblijven in een net met $20 \mathrm{~mm}$ maaswijdte.

Concluderend, de resultaten van de historische bemonsteringen geven inzicht in de diepteverspreiding en dichtheden van de juveniele doelsoorten in de periode voordat is begonnen met het suppleren van zand in de vooroever. Gebaseerd op de bevindingen uit beide bemonsteringen maakte juveniele schol ( 0 en I-groep) gebruik van de gehele vooroever. Gemiddeld hogere dichtheden werden aangetroffen in de zone tot $5 \mathrm{~m}$ diep, de laagste gemiddelde dichtheden werden aangetroffen in de zone dieper dan $10 \mathrm{~m}$.

Juveniele tong leek nauwelijks gebruik te maken van de brandingszone en kwam hier maar sporadisch voor. De hoogste dichtheden juveniele tong werden aangetroffen in de 2-5 m dieptezone, met toenemende diepte namen de dichtheden weer af.

Juveniele tarbot en griet hadden een duidelijke voorkeur om zich te vestigen in het ondiepste water (brandingszone) en deze zone werd het gehele jaar gebruikt om op te groeien. 


\section{De huidige vooroever}

Een literatuurreview (Teal en van Keeken, 2011) liet zien dat de kennis en beschikbaarheid van gegevens over vis in de ondiepe vooroever zeer beperkt was. Om deze kennis te vergroten is er van 2017 tot 2020, als onderdeel van Natuurlijk Veilig, veldwerk uitgevoerd. Dit werd voorafgegaan door een pilotbemonstering in 2016 (Couperus e.a., 2017) waarin verschillende bemonsteringstechnieken werden getest. Voortvloeiend uit Natuurlijk Veilig, maar geen onderdeel van het project is er door een groep vrijwilligers van 2019 - tot heden bemonsterd in de brandingszone vanaf het strand bij Egmond aan Zee, daarnaast is WMR van 2020 - tot heden in de brandingszone vanaf het strand bij IJmuiden gaan bemonsteren. Deze bemonsteringen worden niet uitgebreid besproken, maar waar relevant en beschikbaar zijn er gegevens opgenomen in deze rapportage.

De eerste twee jaar (2017-2018) zijn verschillende gebieden langs de Nederlandse kust (zo genoemde kustvakken) intensief bemonsterd met verschillende technieken. De oorspronkelijke intentie was om deze opzet vanaf 2019 toe te passen in een kustvak waar in de voorafgaande periode een vooroeversuppletie had plaatsgevonden. Een geschikte locatie hiervoor bleek er in de loop van 2018 niet te zijn. Deze ontwikkeling samen met de door weersomstandigheden beperkt geslaagde uitvoering van de plannen in 2017 en 2018 heeft ertoe geleid de oorspronkelijke opzet aan te passen. In 2019 en 2020 is er kustlangs vis bemonsterd. Daarnaast is in 2019 demersale vis in de branding op drie locaties verspreid langs de kust vanaf het strand bemonsterd.

In deze bemonsteringen was het hoofddoel gegevens verzamelen over de aanwezigheid van vis, met name de platvissoorten schol, tong, tarbot en griet. Om inzicht te krijgen in de habitatcondities waarin de vis zich bevindt, zijn er tijdens alle veldwerkzaamheden aanvullende gegevens verzameld van biotische en abiotische variabelen. De visgegevens gecombineerd met deze omgevingsvariabelen moet inzicht geven in de habitatgeschiktheid van de verschillende gebieden.

\subsubsection{Kustvakken 2017-2018}

\subsubsection{Introductie}

Het hoofddoel van de Kustvakken opzet was het bemonsteren van demersale vis in relatie tot de omgevingsvariabelen sediment en diepte. Deze variabelen zijn sleutelfactoren omdat ze kunnen wijzigen als gevolg van zandsuppleties (Guillén en Hoekstra, 1997; Speybroeck e.a., 2006; Ojeda e.a., 2008; Huisman e.a., 2014) en omdat ze een rol spelen in de verspreiding van demersale vis (Jager e.a., 1993; Rogers, 1993; Gibson en Robb, 2000; McConnaughey en Smith, 2000; Post e.a., 2017). Om het oplossend vermogen van de studie-opzet zo hoog mogelijk te maken, is gekozen voor een gestratificeerde opzet naar diepte en sediment waarbij binnen de beschikbare tijd zoveel mogelijk metingen gedaan werden, omdat grote variatie in de samenstelling van de visvangsten verwacht werd. Het was onwaarschijnlijk dat binnen de beschikbare tijd random gekozen stations langs de Nederlandse kust de aanwezige variatie in diepte en sediment zouden weerspiegelen. Daarom werden er vier kustvakken geselecteerd, die op basis van de toentertijd beschikbare gegevens qua diepteprofiel en sediment van elkaar verschilden. De kustvakken waren tevens geselecteerd op basis van kenmerkende eigenschappen voor een groter deel van de Hollandse kust en Waddenkust en een grote variatie in sedimentsamenstelling binnen het vak. Door te kiezen voor vier kustvakken kon op elke locatie een volle week bemonsterd worden. De kustvakken waren bovendien zo gekozen dat ze vanaf een haven gemakkelijk te bereiken waren. Aangezien het schip elke nacht naar een haven terug moest keren. Daarnaast werden de kustvakken zodanig gekozen dat de verwachte variatie in larvenaanvoer van juveniele platvis binnen een kustvak minimaal is, gebaseerd op gemodelleerd larventransport (Bolle e.a., 2009) en waargenomen verspreidingen van 0-groep vis (observaties uit de DFS).

De volgende kustvakken werden geselecteerd:

1. Zuid-Holland. Dit kustvak is kenmerkend voor een Hollandse brekerbankenkust en bevat zowel zeer grove als zeer fijne sedimentfracties.

2. Noord-Holland. Dit kustvak is kenmerkend voor de Hollandse brekerbankenkust. 
3. Texel. Dit kustvak is kenmerkend voor de grovere korrelfractie van de westelijke Waddenkust.

4. Ameland. Dit kustvak is kenmerkend voor de fijne korrelfractie van de oostelijke Waddenkust.

Overige abiotische omgevingsvariabelen die naar verwachting invloed hebben op het voorkomen en/of de vangbaarheid van vis (zoals tij, weer, zicht, saliniteit, stroming) zijn wel geregistreerd, maar zijn niet meegenomen in de stratificatie. Stratificatie op tij is overwogen, maar dit zou het aantal locaties dat bemonsterd kon worden binnen de beschikbare tijd te veel beperken. Om zicht-gerelateerde variatie in de vangbaarheid van vis te reduceren zou het wenselijk zijn om alleen 's nachts te vissen. Vanwege praktische en veiligheidsredenen kon niet aan deze wens worden voldaan.

In Herman e.a. (2016) werden nog andere kennisleemtes geprioriteerd, waaronder voedselweb vooroever, belang vooroever vis, en benthos soortenpool (Species pool). Hiervoor zijn meerdere bemonsteringsmethodes gecombineerd met de bemonstering van demersale vis en sediment. Benthosmonsters zijn genomen om kennis te verkrijgen over de benthos species pool en de aanwezigheid van prooisoorten voor de juveniele vis. Zoöplanktonmonsters zijn genomen op kennis te verkrijgen over de prooisoorten in het pelagische systeem. Aanvullend is pelagische vis bemonsterd, ondanks de verwachting dat deze geen (direct) effect ondervinden van suppleties. De kennis over dit deel van de visgemeenschap in de vooroever is namelijk nog beperkter dan voor het demersale deel.

In 2018 is de survey uit 2017 niet herhaald maar is een extra kustvak bij Schiermonnikoog bemonsterd (van Hal, 2018). De bemonstering is analoog aan 2017 uitgevoerd. De keuze voor Schiermonnikoog was gebaseerd op de wens van de opdrachtgever en convenantpartners om te bemonsteren nabij de Waddeneilanden, mede omdat de bemonsteringen in 2017 bij de eilanden niet volledig uitgevoerd kon worden. Het eerste voorstel was om de bemonstering van Ameland te herhalen, maar daar bleek in 2018 een vooroeversuppletie te zijn gepland. Daarop is Schiermonnikoog gekozen om aan te sluiten bij eerdere benthosbemonsteringen uitgevoerd in EGS1 (Van Dalfsen e.a., 2014; Damsma e.a., 2017).

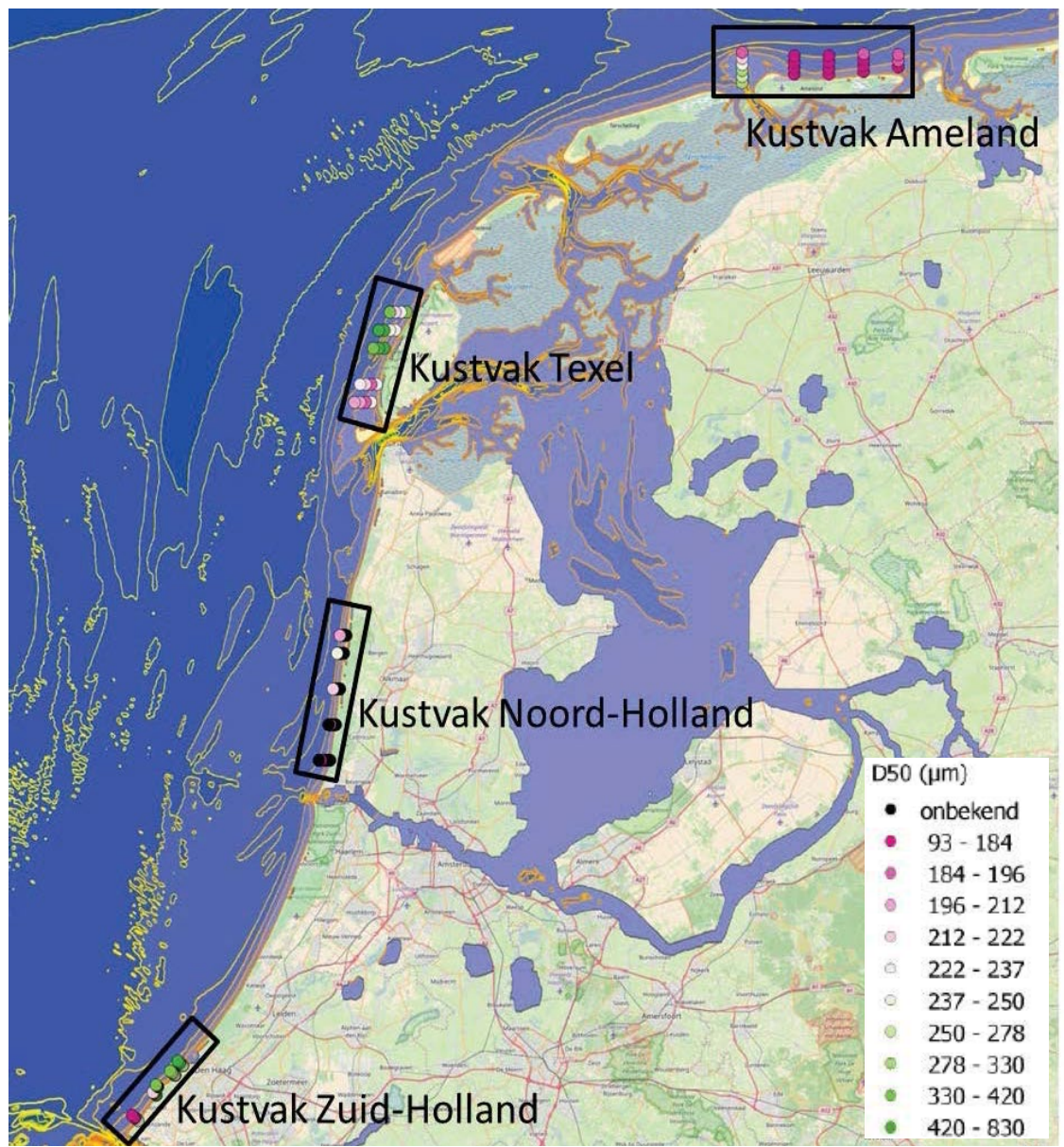

Figuur 5.1 Verdeling van de kustvakken bemonsterd in 2017, de kleuren geven de vooraf ingeschatte mediane korrelgrootte(D50). 


\subsubsection{Algemene opzet}

De kustvakken zijn bemonsterd vanaf het Rijkswaterstaat onderzoeksschip de Luctor. De Luctor was in 2017 vier aaneengesloten werkweken beschikbaar (12 juni - 9 juli 2017; week 24 t/m 27), in 2018 was de Luctor één week beschikbaar (18-22 juni 2018; week 25). Iedere week werd een ander kustvak bemonsterd. In 2017 zijn achtereenvolgens de kustvakken Zuid-Holland, Noord-Holland, Texel en Ameland bemonsterd (Figuur 5.1). In 2018 is het kustvak Schiermonnikoog bemonsterd. In ieder kustvak waren vijf en in Schiermonnikoog zes raaien gepland vanaf het strand tot een diepte van ongeveer 10-12 meter. Op iedere raai bevonden zich zeven locaties, waarop verschillende technieken gericht op verschillende biota werden uitgevoerd (Tabel 5.1). Een beschrijving wordt hieronder per methode weergegeven en is uitgebreider beschreven in de meetplannen (Baptist e.a., 2017; van Hal, 2018).

Tabel 5.1 Bemonsteringsintensiteit per bemonsteringstechniek.

\begin{tabular}{|c|c|c|c|}
\hline Bemonsteringstechniek & Aantal stations per raai & Aantal stations per kustvak & Totaal \\
\hline \multicolumn{4}{|l|}{ Zone 0-1 m (lopend) } \\
\hline korte steekbuis & 1 & 6 & 6 \\
\hline $2 \mathrm{~m}$ boomkor (licht) & 1 & 6 & 6 \\
\hline strandzegen & 1 & 6 & 6 \\
\hline temperatuur en saliniteit & 1 & 6 & 6 \\
\hline \multicolumn{4}{|l|}{ Zone 1-3 m (rubberboot) } \\
\hline verlengde steekbuis & 2 & 12 & 12 \\
\hline $2 \mathrm{~m}$ boomkor & 2 & 12 & 12 \\
\hline CTD \& Secchi & 2 & 12 & 12 \\
\hline \multicolumn{4}{|l|}{ Zone 3-10 m (Luctor) } \\
\hline boxcorer & 4 & 24 & 24 \\
\hline 3 m boomkor (DFS) & 4 & 24 & 24 \\
\hline echolood & 4 & 24 & 24 \\
\hline zoöplanktonnet & 1 & 6 & 6 \\
\hline CTD \& Secchi & 4 & 24 & 24 \\
\hline stereocamera & 4 & 24 & 24 \\
\hline
\end{tabular}

Werken in de vooroever is vanwege de beperkte diepte en daarmee een beperkte maximale diepgang van het schip zeer weersafhankelijk. Met name als zware bemonsteringsapparatuur (stereocamera, en de boxcorer) gebruikt worden. Ook het werk vanuit de rubberboot en lopend vanaf het strand is weersafhankelijk omdat bij te hoge golven $(>0,6 \mathrm{~m})$ het gebruikte bemonsteringstuig niet meer optimaal functioneert of het niet mogelijk was om met de rubberboot op het strand te komen. Door deze beperkingen zijn er minder locaties bemonsterd dan gepland in de vooraf vastgelegde periode waarin het schip beschikbaar was. In 2018, is er op 27 juni bij Schiermonnikoog een bemonstering uitgevoerd, waarbij met de rubberboot vanaf het strand is bemonsterd (Tabel 5.2).

Tabel 5.2 Uitgevoerde bemonsteringen per kustvak: $x=$ visbemonstering; $b=$ boxcorer; $s=$ steekbuis; $c=$ stereocamera.

\begin{tabular}{|c|c|c|c|c|c|c|c|c|c|c|c|c|c|c|c|c|c|c|c|c|c|c|c|c|c|c|}
\hline \multirow[b]{2}{*}{ Raai $\mathrm{nr}->$} & \multicolumn{5}{|c|}{ Zuid-Holland } & \multicolumn{5}{|c|}{ Noord-Holland } & \multicolumn{5}{|c|}{ Texel } & \multicolumn{5}{|c|}{ Ameland } & \multicolumn{6}{|c|}{ Schiermonnikoog } \\
\hline & 1 & 2 & 3 & 4 & 5 & 1 & 2 & 3 & 4 & 5 & 1 & 2 & 3 & 4 & 5 & 1 & 2 & 3 & 4 & 5 & 1 & 2 & 3 & 4 & 5 & 6 \\
\hline Strand 1 & xs & xs & $\times s$ & $\times s$ & & $\mathrm{xs}$ & $\times s$ & $\times s$ & xs & x s & & & & & & & & & & & $\mathrm{xs}^{1}$ & $\mathrm{xs}^{1}$ & $x^{1}$ & $x^{1}$ & & \\
\hline Rub-boot 2 & $x$ & $x$ & $x$ & & & $x$ & $x s^{3}$ & $x s^{3}$ & $x s^{3}$ & $x \mathrm{~s}^{3}$ & & & & & & & & & & & $x s^{1}$ & & $\times s^{1}$ & $x s^{1}$ & & \\
\hline Rub-boot 3 & $\mathrm{x}$ & $x$ & $x$ & $x$ & & $\mathrm{x}$ & & $x s^{3}$ & $x \mathrm{~s}^{3}$ & $x \mathrm{~s}^{3}$ & & & & & & & & & & & $x^{1}$ & & $x s^{1}$ & $x \mathrm{~s}^{1}$ & & \\
\hline Luctor 4 & $\mathrm{xb}$ & $x b$ & $x b$ & $x b$ & $x b$ & & $x b c$ & $x b c$ & $x b c$ & $x b$ & $\mathrm{xb}$ & $x$ & $x$ & $x$ & $x$ & & $\mathrm{xb}$ & & $\mathrm{xb}$ & & $\mathrm{xb}$ & $\mathrm{xb}$ & $x b$ & $x b$ & & \\
\hline Luctor 5 & $\mathrm{xb}$ & $x b$ & $x b$ & $x b$ & $x b$ & $\mathrm{xbc}$ & $\mathrm{xbc}$ & $x b c$ & $\mathrm{xbc}$ & $x b$ & $x b$ & $x$ & $x$ & $x b$ & $x$ & & $\mathrm{xb}$ & & $x b$ & & $\mathrm{xb}$ & $x b$ & $x b$ & $x b$ & $x b^{2}$ & \\
\hline Luctor 6 & $\mathrm{xb}$ & $x b$ & $x b$ & $x b$ & & $\mathrm{xb} c$ & $\mathrm{xbc}$ & $x b c$ & $x b c$ & $x b$ & $x b$ & $x$ & $x b$ & $x$ & $x b$ & & $\mathrm{xb} c$ & & $x b c$ & & $x$ & $x b$ & $x b$ & $x b$ & $x b^{2}$ & \\
\hline Luctor 7 & $\mathrm{xbc}$ & $\mathrm{xb}$ & $\mathrm{xb}$ & $x b$ & & $\mathrm{xb} c$ & $x b c$ & $x b c$ & $x b c$ & $x b c$ & $x b$ & $\mathrm{x}$ & $x b$ & $\mathrm{Xb}$ & $\mathrm{xb}$ & & $\mathrm{xb} c$ & & $x b c$ & & $\mathrm{xb}$ & $\mathrm{xb}$ & $\mathrm{xb}$ & $\mathrm{xb}$ & $x b^{2}$ & \\
\hline
\end{tabular}

${ }^{1}$ Bemonsteringen uitgevoerd vanaf het strand tijdens de extra dag

${ }^{2}$ CTD zwaar beschadigd en niet meer uit te lezen.

${ }^{3}$ Monsters duikend genomen met korte steekbuis, omdat tijdens monstername met de verlengde steekbuis in 2017 constant het losse zand uit de steekbuis spoelde voordat het monster aan boord kwam. 


\subsubsection{Demersale vis}

Demersale vis is in de drie dieptezones bemonsterd met een boomkor met een maaswijdte van $10 \mathrm{~mm}$ gestrekt (in de kuil). Dit is vistuig ontworpen voor het vangen van met name kleine platvis, en overige beperkt zwemmende vis die zich op of nabij de bodem bevindt. Volledige ingegraven soorten, zoals de zandspiering, en snel zwemmende of naar boven vluchtende soorten worden met dit tuig minder goed gevangen.

1) Luctor: $3 \mathrm{~m}$ boomkor, met 1 wekkerketting. Zelfde tuig als gebruikt in de reguliere Demersal Fish Survey (DFS), alleen dan wordt een $20 \mathrm{~mm}$ maaswijdte gebruik.

2) Rubberboot: $2 \mathrm{~m}$ boomkor met een ketting op de onderpees.

3) Lopend: lichtere $2 \mathrm{~m}$ boomkor.

Tijdens de eerst 4 Luctor-vistrekken in 2017 was de wekkerketting niet aan het tuig bevestigd.

Idealiter wordt dezelfde boomkor gebruikt in alle dieptezones vanwege verschillen in vangstefficiëntie (Kuipers, 1975). In de praktijk is dit onmogelijk omdat het zwaardere DFS-tuig niet te trekken is door een rubberboot of lopend en het lichte tuig niet goed over de bodem gaat in de diepste zone.

De geplande trekduur was vijf minuten, waardoor een beperkt oppervlak werd bemonsterd. Het aantal monsterlocaties voor een goede ruimtelijke dekking is daarmee echter relatief hoog binnen de beschikbare tijd. De vangsten in het kustvak Zuid-Holland in 2017 waren onverwachts klein, ook de vangsten waarbij de wekkerketting wel aan het tuig was bevestigd. Vandaar is besloten vanaf trek 11 tot 19 de trekduur te verlengen tot 15 minuten.

De vangsten zijn op soort gebracht. De platvissen zijn op de $\mathrm{mm}$ gemeten en op de gram nauwkeurig gewogen. De overige vissoorten zijn alleen op de $\mathrm{mm}$ nauwkeurig gemeten. De benthische soorten in de vangst zijn geteld. Een deel van de juveniele platvissen, in 2017 , is verzameld voor latere analyses om op basis van de RNA:DNA-ratio de groeisnelheid te bepalen (Rutting, 2017).

\subsubsection{Pelagische vis}

Pelagische vis is vanaf het strand bemonsterd met een strandzegen. De strandzegen bestaat uit een centraal deel met een 'zak' en twee 'vleugels' aan de zijkanten en wordt door twee personen ieder aan een zijde voortgetrokken. De zegen werd vanaf het strand in ca. $80 \mathrm{~cm}$ diep water uitgezet, vijf minuten parallel aan de kustlijn gesleept en dan het strand opgetrokken. De vangsten zijn op dezelfde manier verwerkt als de demersale vis, alleen zijn ook haring, sprot en zandspiering gewogen.

Pelagische vis is vanaf de Luctor bemonsterd met twee transducers met een frequentie van $200 \mathrm{kHz}$. Eén werd voortgetrokken naast het schip (towed body) en één vanuit de boeg. Met behulp van de akoestische signalen is de dichtheid van de aanwezige vis in de waterkolom bepaalt. Het principe is dat het totale oppervlak van gereflecteerd geluid (Area scattering coëfficiënt, $\mathrm{m}^{2} / \mathrm{nm}^{2}$ ) wordt gedeeld door het - experimenteel bepaalde of gemodelleerde - akoestische oppervlak van één vis van gemiddelde lengte (Simmonds en MacLennan, 2008). Het akoestische oppervlak verschilt tussen vissoorten waardoor de dichtheid per soort kan verschillen voor hetzelfde totale oppervlak gereflecteerd geluid. Om te kunnen omrekenen is het noodzakelijk de vissoort te weten, daarvoor wordt bij dit akoestisch onderzoek geregeld gevist. Pelagisch vissen vanaf de Luctor, was ondanks plannen daarvoor, technisch niet mogelijk. Hierdoor konden de echo's niet toegekend worden aan soorten, en is alleen totaal gereflecteerd geluid geanalyseerd. De resultaten van 2017 en 2018 bemonstering zijn gerapporteerd in een losstaand rapport (Couperus e.a., 2020), hier worden uitsluitend de belangrijkste uitkomsten en conclusies weergegeven.

\subsubsection{Bodemdieren en sediment}

De bodemdieren zijn bemonsterd met korte steekbuizen (interne $\varnothing 103 \mathrm{~mm}, 0-1 \mathrm{~m}$, lopend), verlengde steekbuizen (interne $\varnothing 105 \mathrm{~mm}, 1-3 \mathrm{~m}$, rubberboot) en een boxcorer (3-10 m, Luctor). Met de steekbuizen zijn op 25 stations twee bodemmonsters tot een diepte van $35 \mathrm{~cm}$ genomen en samengevoegd. Aanvullend is op ieder station met een steekbuisje, $\varnothing 24 \mathrm{~mm}$, een sedimentmonster genomen tot een diepte van $8 \mathrm{~cm}$.

74 monsters met zijn er genomen met de MWTL-boxcorer met een oppervlakte van $0.078 \mathrm{~m}^{2}$ en een monsterdiepte van minimaal $15 \mathrm{~cm}$. Uit iedere boxcorer is met een kleine sedimentsteekbuis een sedimentmonster genomen. 
Alle benthosmonsters zijn gezeefd over een $4 \mathrm{~mm}$ zeef en vervolgens ingevroren. In het lab zijn de organismen in deze monsters op soort gebracht, voor bepaalde soorten ingedeeld in lengteklassen en vervolgens zijn de aantallen geteld. Voor de schelpdierensoorten uit de monsters uit 2017 zijn lengtebiomassa (asvrij drooggewicht) regressielijnen bepaald. Voor de overige soorten uit 2017 is de totale biomassa per station bepaald.

De bodemdiergegevens zijn beschikbaar gemaakt via Informatie Huis Marien en gedeeld met Deltares. Deltares heeft de verdere analyse van de bodemdiergegevens uitgevoerd (Herman e.a., 2021). De resultaten van de bodemdieren worden in het voorliggende rapport niet apart behandeld.

De sedimentmonsters zijn naar het NIOZ-lab op Texel gegaan, en daar zijn de monsters gezeefd over $2 \mathrm{~mm}$ en is de korrelgroottesamenstelling bepaald met een Malvern mastersizer 2000.

\subsubsection{Zoöplankton}

Zoöplanktonmonsters zijn verzameld op het diepste station van elke raai met een WP2 planktonnet, $200 \mu \mathrm{m}$ maaswijdte. Het net werd naar beneden gelaten tot een halve meter boven de bodem, direct na het bereiken van de bodempositie werd het net gehaald met een snelheid van $1 \mathrm{~m} / \mathrm{s}$. De verzamelde monsters werden gezeefd in een $200 \mu \mathrm{m}$ planktonzeefje en aan boord bewaard in $4 \%$ formaline. In het lab zijn de monsters uitgezocht op soort. De resultaten van de zoöplankton gegevens zijn onderdeel van de aparte rapportage over de pelagische vis (Couperus e.a., 2020), maar worden hier kort samengevat.

\subsubsection{Stereocamera}

Een 3D stereocamera is ingezet vanaf de Luctor om met een snelheid van 4 frames per seconde foto's van de zeebodem te maken. Daarvoor werd de camera 5 tot 10 minuten langzaam boven de bodem voortgesleept. Er zijn opnames gemaakt op 21 stations, de kwaliteit van de beelden varieert met name door invloed van de golven. De camera heeft enkele mooie video's opgeleverd (Figuur 5.2), maar door de beperkte inzetbaarheid, weersomstandigheden en technische problemen, zijn de gegevens niet geanalyseerd op de aanwezigheid van bodemdieren of de structuur van de bodem.

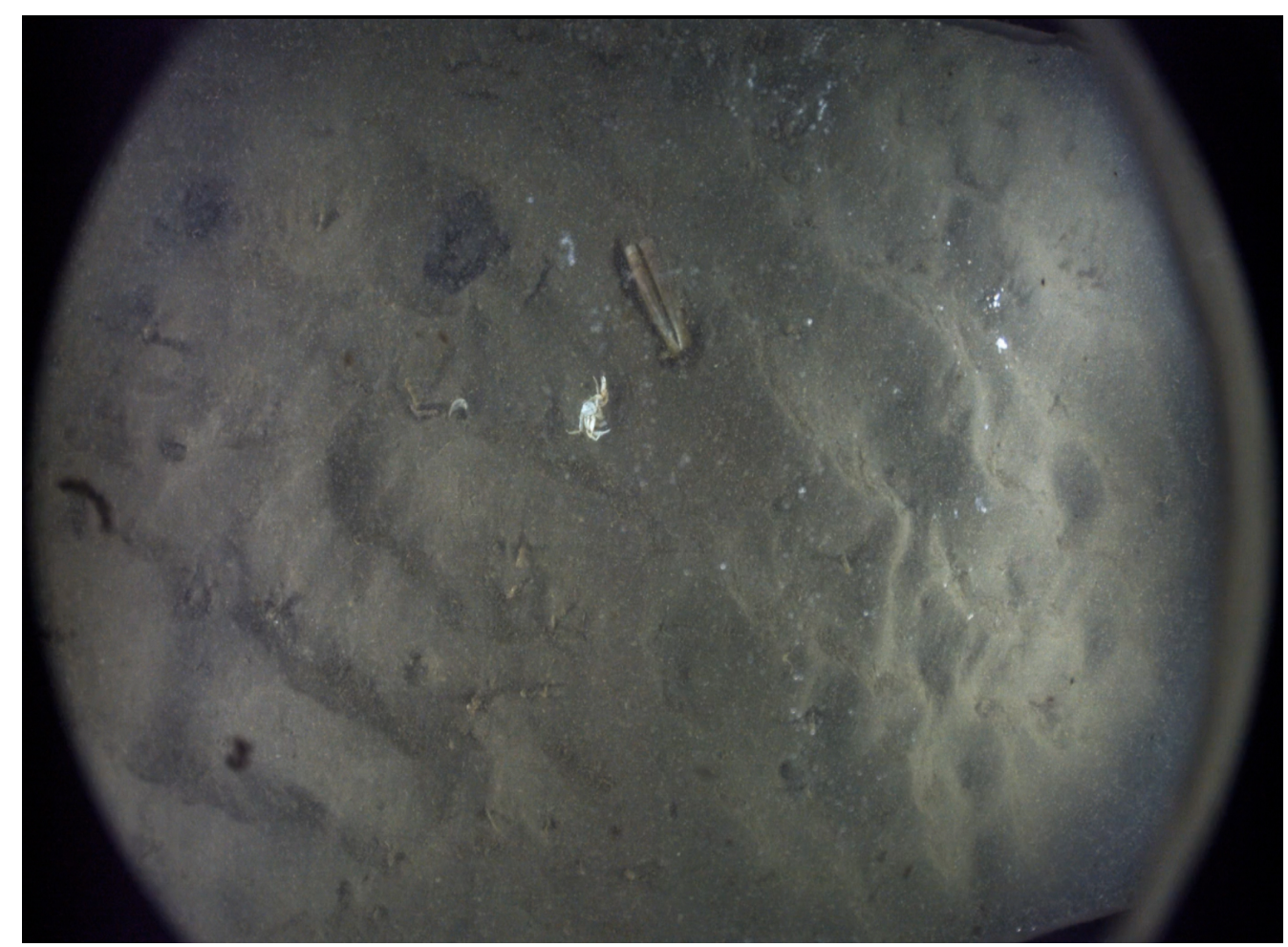

Figuur 5.2 Video-opnames van de onderwatercamera. 


\subsubsection{Omgevingsvariabelen}

De watertemperatuur, de conductiviteit (proxy voor saliniteit), en turbiditeit zijn gemeten met een CTD bevestigd op het vistuig of met een multimeter vanuit de hand. Daarnaast is op de meeste locaties het doorzicht bepaald met een Secchi-schijf.

\subsubsection{Kustlangse bemonstering 2019-2020}

\subsubsection{Algemene opzet}

De Luctor was ongeveer een week beschikbaar in 2019 (17-21 juni) en 2020 (16-23 juni). In beide jaren is in de beschikbare tijd een kustlangse bemonstering is uitgevoerd. De kustvakbemonsteringen hadden laten zien dat de meeste juveniele platvis gevangen werd op een diepte van 4-6 m, vandaar dat er besloten is vooral op deze diepte te bemonsteren. In 2019 is er bemonsterd vanaf de tweede Maasvlakte tot aan de razende Bol nabij Texel, op deze manier zijn er 62 stations op een diepte van 4$6 \mathrm{~m}$ en 7 stations op een diepte van 6-16 m bemonsterd. In 2020, is er noordelijker gestart ter hoogte van IJmuiden en bemonsterd tot halverwege Texel, toen zijn er op een diepte van 3-6 m 57 stations en op een diepte van 7-12 m 24 stations bemonsterd. Aanvullend zijn in 2020 monsters genomen in de Waddenzee, Balgzand. Het verzamelen van deze monsters had tot doel het vergelijken van de vangsten met eerdere publicaties over dit gebied om een betere indicatie te krijgen van de vangstefficiëntie van het gebruikte tuig. Aanvullend op de bemonsteringen op 4-6 $m$ diepte is een aantal raaien naar dieper water bemonsterd. In 2019 waren dit er twee (ter hoogte van Scheveningen en Castricum), en in 2020 waren dit er zeven (ter hoogte van IJmuiden, Castricum, Egmond, Petten, Callantsoog, en twee bij Texel). De gedetailleerde beschrijving van deze bemonsteringen is te vinden in (van Hal en Dijkman-Dulkes, 2019; Vrooman e.a., 2020b).

\subsubsection{Demersale vis}

$\mathrm{Er}$ is bemonsterd met dezelfde $3 \mathrm{~m}$ boomkor als in de eerdere twee jaar. De trekduur was 5 minuten, behalve de trekken op het Balgzand en in het Amsteldiep die ingekort zijn tot 2-3 minuten omdat het net volliep met zeesla. De visvangsten zijn op dezelfde manier verwerkt als in de eerdere bemonsteringen. In enkele gevallen zijn er otolieten verzameld voor aanvullende gegevens over de platvissen, schol, tong, tarbot en griet. Ook zijn er platvissen verzameld voor analyses van de maaginhouden (van Berkel, 2020; Meppelink, 2021).

\subsubsection{Sediment}

Op iedere locatie is er met een kleine Van Veen happer een sedimentmonster genomen. Uit iedere hap is met een steekbuis ( $\varnothing 26 \mathrm{~mm}$ ) een core genomen voor korrelgrootte-analyse. In tegenstelling, tot de eerste twee jaar, zijn deze monsters geanalyseerd op een Malvern mastersizer 3000 van de WURleerstoelgroep Levensmiddelen Proceskunde in Wageningen. De reden was dat het NIOZ-lab op het betreffende moment in 2019 niet de capaciteit had om deze monsters nog te kunnen analyseren.

\subsubsection{Omgevingsvariabelen}

Temperatuur, conductiviteit en turbiditeit zijn geregistreerd met een CTD bevestigd op de boomkor. In 2020 zijn alle gegevens goed geregistreerd, in 2019 waren er problemen met de turbiditeitssensor. Met de Secchi-schijf is op ieder station het doorzicht bepaald.

\subsubsection{Strandbemonstering 2019}

\subsubsection{Algemene opzet}

In aanvulling op de kustlangse Luctorbemonstering, is er in 2019 bemonsterd vanaf het strand (van der Geest, 2019). Deze bemonstering is grotendeels uitgevoerd met behulp van vrijwilligers, waardoor de opzet omvangrijker werd dan in eerste instantie binnen de projectmogelijkheden van Natuurlijk Veilig gepland was. In plaats van op een locatie kon er op drie locaties, Katwijk aan Zee, Castricum aan Zee en Texel (Paal 12), bemonsterd worden vanaf het strand met een kornet. Dit is een net dat al eerder ingezet werd voor strandbemonsteringen door stichting Anemoon. Het is een tuig met een uitscherend bordje waarmee gevist kan worden lopend langs de branding. De horizontale opening is $1,8 \mathrm{~m}$, en het net heeft in de kuil een maaswijdte van $2 \mathrm{~cm}$ gestrekt.

$\mathrm{Er}$ is, afhankelijk van de weersomstandigheden, ongeveer iedere twee weken bemonsterd vanaf eind maart tot eind juni. De bemonstering vond plaats rondom laag water en op enkele uitzondering na is 
er gevist over een afstand van $\sim 100 \mathrm{~m}$. Er werden drie ongeveer aangesloten trekken gedaan, die vervolgens op dezelfde manier werden terug bevist. Dit resulteerde in 6 monsters per dag (Tabel 5.3). Aanvullend is er, wanneer tijd het toeliet, met verschillende boomkorren (Texel: $1 \mathrm{~m}$ en $2 \mathrm{~cm}$ gestrekte maas; Castricum 2 m en $1 \mathrm{~cm}$ gestrekte maas; Katwijk 1,5 m en $2 \mathrm{~cm}$ gestrekte maas) gevist op dezelfde locaties.

Tabel 5.3 Uitgevoerde strandbemonsteringen per locatie. Eerste getal: aantal stations met het kornet, tweede getal: aantal stations met de boomkor.

\begin{tabular}{|l|c|c|c|}
\hline 2019 & Katwijk aan Zee & Castricum aan Zee & Texel Paal 12 \\
\hline 23 -maart & 6 & 6 & 6 \\
\hline 6 april & 6 & 6 & $6 / 2$ \\
\hline 20 april & 6 & 6 & $6 / 2$ \\
\hline 5 mei & & & 6 \\
\hline 10 mei & & $6 / 3$ & $6 / 1$ \\
\hline 18 mei & 6 & $6 / 5$ & $6 / 6$ \\
\hline 22 juni & $6 / 6$ & $6 / 6$ & $6 / 6$ \\
\hline
\end{tabular}

\subsubsection{Vangstverwerking}

De vangst is op soort gebracht. De vis is op de mm-nauwkeurig gemeten en de overige soorten, zoals benthische soorten, kwallen en garnalen geteld. De platvissen, schol, tong, tarbot en griet zijn in de meeste gevallen gedood en opgeslagen in ethanol voor de bepaling van dieet.

\subsubsection{Sediment}

Op het startpunt van de drie stations is per bemonsteringsdag in de brandingszone met een sedimentsteekbuis ( $\varnothing 26 \mathrm{~mm}$ ) een $7 \mathrm{~cm}$ diep sedimentmonster genomen. Van deze monsters is met een Beckman Coulter LS 13320 in het lab van het NIOZ op Texel de korrelgrootte bepaald.

\subsubsection{Omgevingsvariabelen.}

Temperatuur en saliniteit zijn iedere bemonsteringsdag bepaald met een multimeter. Doorzicht is bepaald met een Secchi-schijf.

\subsection{Analyses}

\subsubsection{Sediment}

De korrelgrootte analyses leveren de fracties per korrelgrootteklasse. Er zat iets verschil in de indeling in korrelgrootteklasse tussen de gebruikte analyseapparaten, maar de indeling bestond voor alle apparaten uit een groot aantal klassen van 0 tot $2000 \mu \mathrm{m}$, of voor het apparaat van de WUR tot 3000 $\mu \mathrm{m}$. Op basis van de fracties per korrelgrootteklasse is voor ieder monster de mediane korrelgrootte (D50) en de 10 (D10) en 90 (D90) percentiel bepaald. Daarnaast is het slibgehalte, de gesommeerde fracties < $64 \mu \mathrm{m}$, bepaald. De lineaire correlaties tussen de D10, D50 en D90 worden weergegeven. D50 en het slibgehalte zijn gebruikt voor het maken van een gebiedsdekkende kaart. Hiervoor zijn alle sedimentmonsters tezamen met behulp van een general addative model (gam, R-package mgcv) gecorreleerd met de waterdiepte. De diepte is afkomstig van een gebiedsdekkende kaart voor 2010 met een raster van 25×25 m waarvan de gegevens zijn verzameld door RWS-DID en de Dienst der Hydrografie. De gegevens zijn samengebracht door Deltares (van Dijk e.a., 2011). Vervolgens is de gebiedsdekkende kaart voor waterdiepte gebruikt om met behulp van de GAM-relatie voor iedere rastercel de D50 en het slibgehalte te voorspellen. Deze gebiedsdekkende kaarten zijn later gebruikt in de habitatmodellering.

Op dezelfde manier zijn gebiedsdekkende kaarten voor doorzicht (Secchi-schijf) en zoutgehalte bij de bodem gemaakt. 


\subsubsection{Principale componenten analyse}

Om inzicht te krijgen in de ruimtelijk verdeling van de gevangen demersale soortsamenstelling is er gebruik gemaakt van een Principale Componenten Analyse (PCA). Hiervoor zijn alle demersale vissoorten die minimaal in 8 trekken waren gevangen meegenomen. De aantallen per soort per oppervlakte zijn In-getransformeerd. De getransformeerde waarden zijn met behulp van de R-functie "pcrcomp" (R Core Team, 2020) geanalyseerd.

\subsubsection{Habitatmodellering}

Een general addative mixed model (GAMM) is gebruikt om voor de gegevens verzameld met de Luctor de correlaties tussen het aantal vis per soort per oppervlakte en de omgevingsvariabelen:

waterdiepte, sediment (D50 of Slibgehalte), zoutgehalte bij de bodem, en doorzicht (Secchi-schijf) te bepalen. Het jaar waarin de monsters zijn genomen is meegenomen als random effect en de aantallen vis zijn In-getransformeerd. In de eerste stap is het volledige model, met alle omgevingsvariabelen, gefit. De figuren hiervan zijn weergegeven in Bijlage 7. Vervolgens zijn niet significante omgevingsvariabelen verwijderd, waarna alleen de significante variabelen zijn behouden.

Dit model is gebruikt om de aanwezigheid van doelsoorten in de kustzone te voorspellen aan de hand van de gebiedsdekkende kaarten voor de omgevingsvariabelen.

\subsection{Omgevingsvariabelen}

\subsubsection{Korrelgrootteverdeling van het sediment}

Sedimentmonsters zijn tijdens de verschillende surveys op de meeste locaties genomen, resulterend in 323 monsters. Deze zijn geanalyseerd op verschillende apparaten waardoor er enig verschil kan zitten in waardes (Wijnhoven, 2008). Desondanks is alles hier samengevoegd.

De mediane korrelgrootte (D50) wordt algemeen gebruikt als proxy voor korrelgroottesamenstelling. In het overgrote deel van de monsters blijkt de D50 een redelijke beschrijving te zijn en te correleren met andere waardes als de D10 en D90 (Figuur 5.3).
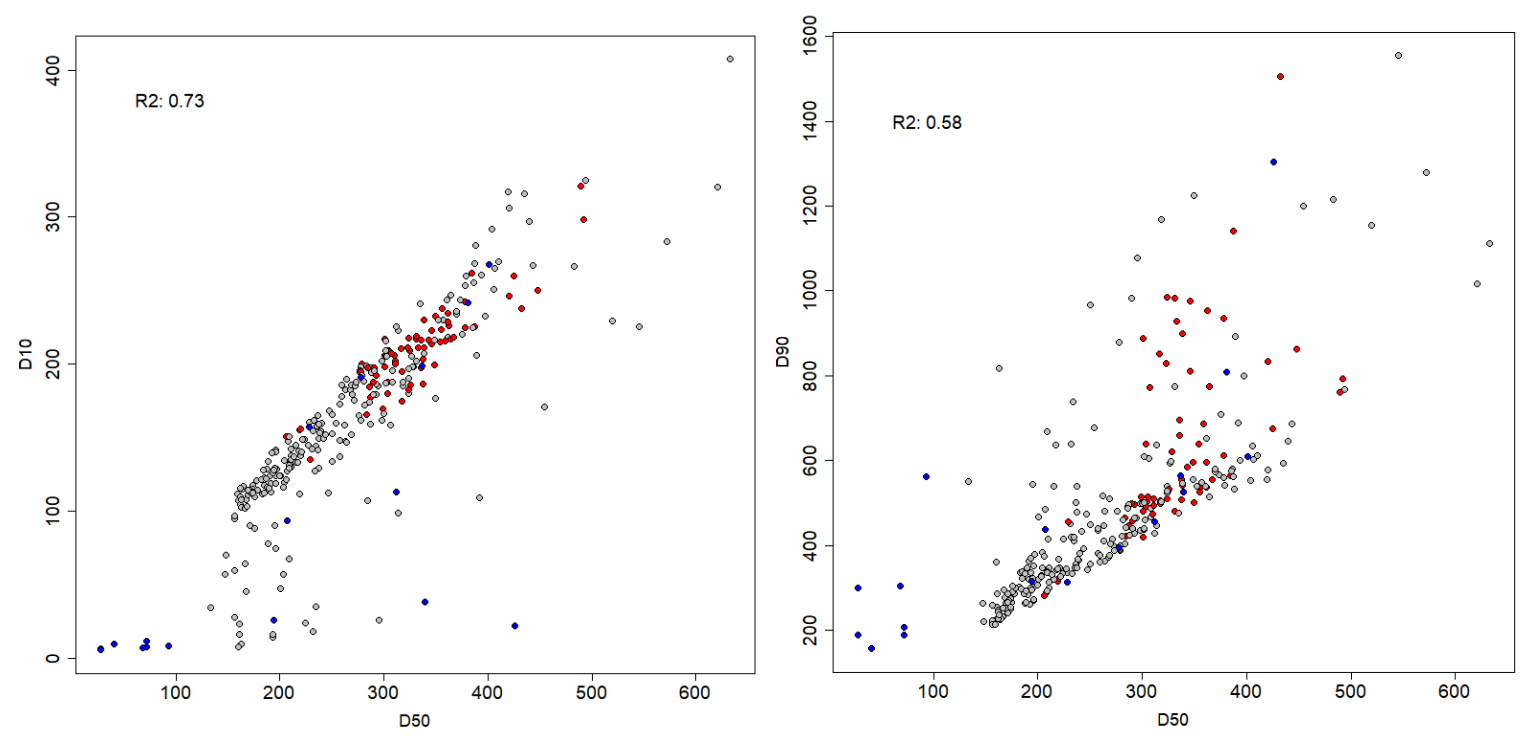

Figuur 5.3 Korrelgrootte D50 ( $\mu \mathrm{m})$ tegen D10 ( $\mu \mathrm{m})$ en D90 ( $\mu \mathrm{m})$. De blauwe cirkels zijn monsters uit 2020 genomen in de Waddenzee, de rode cirkels zijn monsters uit de brandingszone $<1 \mathrm{~m}$ waterdiepte.

De sedimentmonsters genomen in 2020 in het Amsteldiep in de Waddenzee bestonden uit fijner materiaal dan de overige monsters. De meeste monsters genomen in het Marsdiep/Malzwin zijn minder afwijkend. De monsters genomen in de brandingszone $(<1 \mathrm{~m})$ bevatten over het algemeen weinig fijn materiaal en zijn wat grover (Figuur 5.4). 

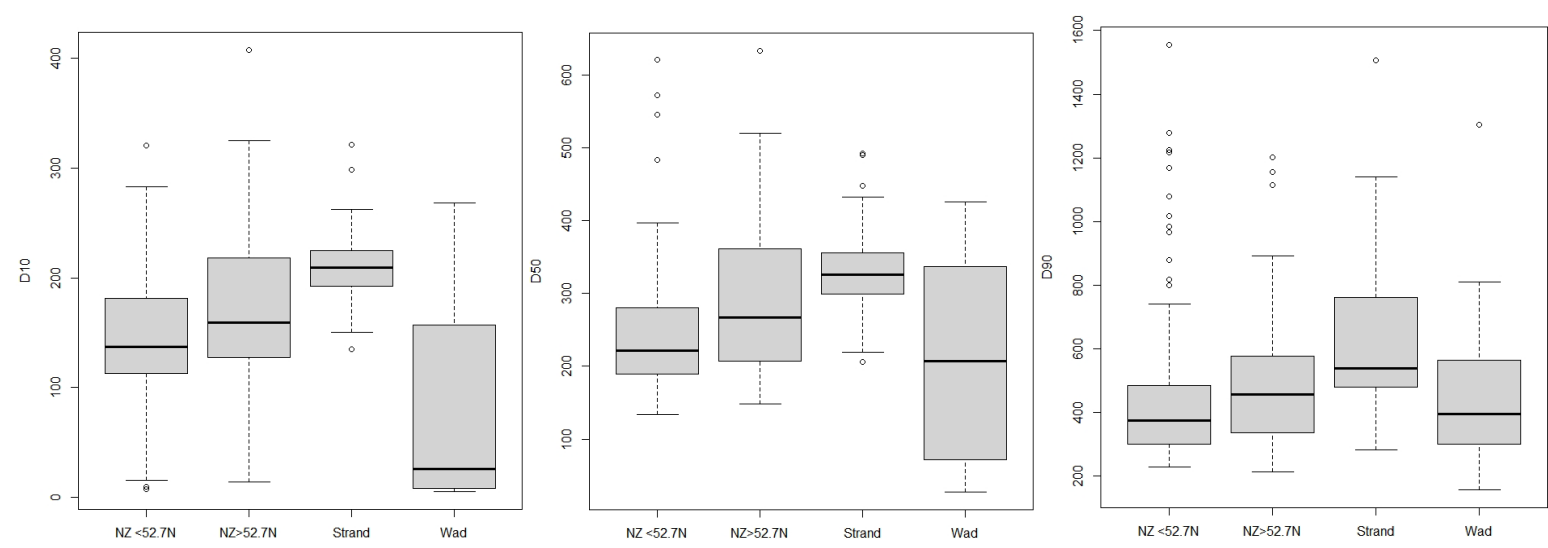

Figuur 5.4 Korrelgrootte D10, D50 en D90 $(\mu \mathrm{m})$ per gebied. Monsters uit de Noordzee ten zuiden van 52,7N; Noordzee ten noorden van 52,7N, monsters in water $<1 \mathrm{~m}$; monsters uit de Waddenzee.

De sedimentmonsters genomen tijdens de strandbemonstering in 2019 geven een beeld van de lokale veranderingen in het sediment in de brandingszone over de tijd (Figuur 5.5). Met name bij Texel is er veel variatie tussen de monsters. Tussen de drie monsters, genomen op enkele honderden meters uit elkaar, zit op sommige dagen ruim $100 \mu \mathrm{m}$ verschil in de mediane korrelgrootte. Verder vindt er, met name in Katwijk, een afname in korrelgrootte over de tijd plaats. Dit houdt mogelijk verband met de rustigere weerscondities later in seizoen waardoor fijner materiaal gemakkelijker blijft liggen. Het tegenovergestelde is waarschijnlijk de verklaring voor de toename in D50 van 5 mei op Texel, en 10 mei bij Castricum aangezien dat een periode met zeer onstuimige omstandigheden was. De reden dat de bemonstering op 5 mei bij Castricum en Katwijk niet kon worden uitgevoerd.
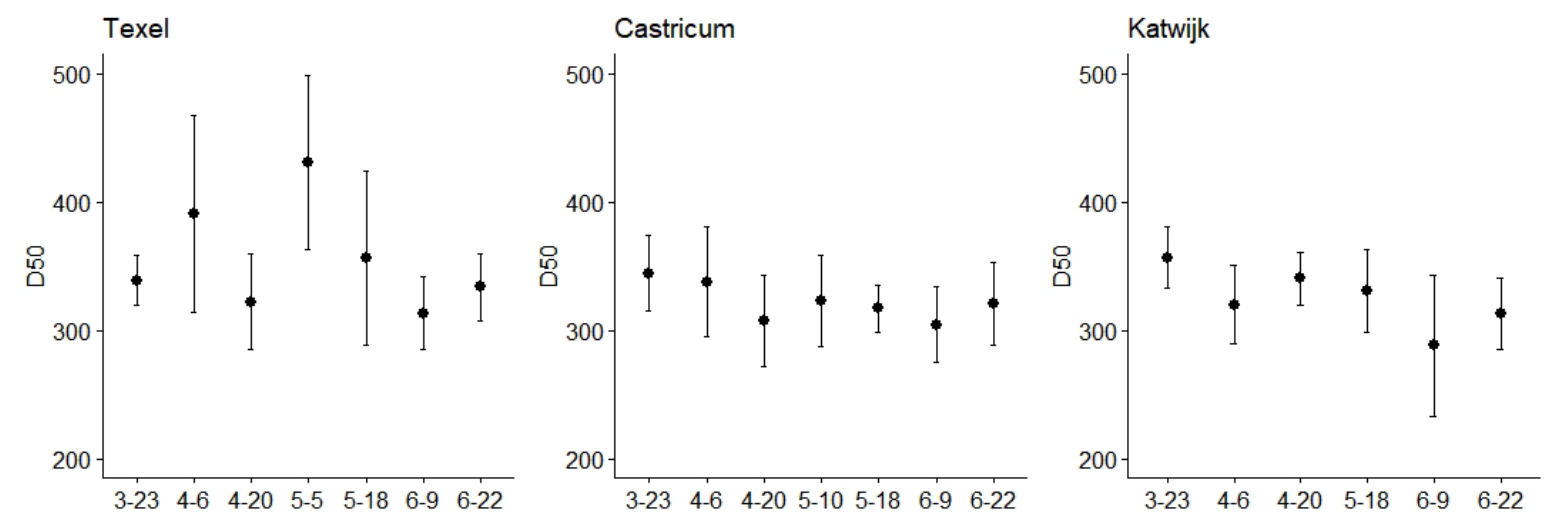

Figuur 5.5 Korrelgrootte D50 ( $\mu \mathrm{m})$ per gebied van de strandbemonstering in 2019. Per dag is er op drie stations een sedimentmonster genomen.

\subsubsection{Ruimtelijke verspreiding sedimentsamenstelling}

Om op ruimtelijke schaal voorspelling te doen over de aanwezigheid van vis in relatie tot de sedimentsamenstelling is een gebiedsdekkende kaart van de sedimentsamenstelling gemaakt. Op basis van alle genomen monsters is geprobeerd de verspreiding van de D50 en het slibgehalte in de vooroever te modelleren op basis van de ruimtelijke correlatie en de relatie met de waterdiepte. De resultaten van deze modellering voor de waterdiepte $<15 \mathrm{~m}$ zijn weergegeven in Figuur 5.6 en Figuur 5.7. Er is een zeer beperkt gebied bemonsterd voor sediment, waardoor de gebiedsdekkende kaarten zeer grof zijn en deze maar geringe variatie op een kleine ruimtelijke schaal kan laten zien. Daarnaast is diepte uiteraard niet de enige verklarende variabele voor de sedimentsamenstelling, waarmee de figuren geen hele accurate voorspeling zijn, maar wel een globaal inzicht geven. 

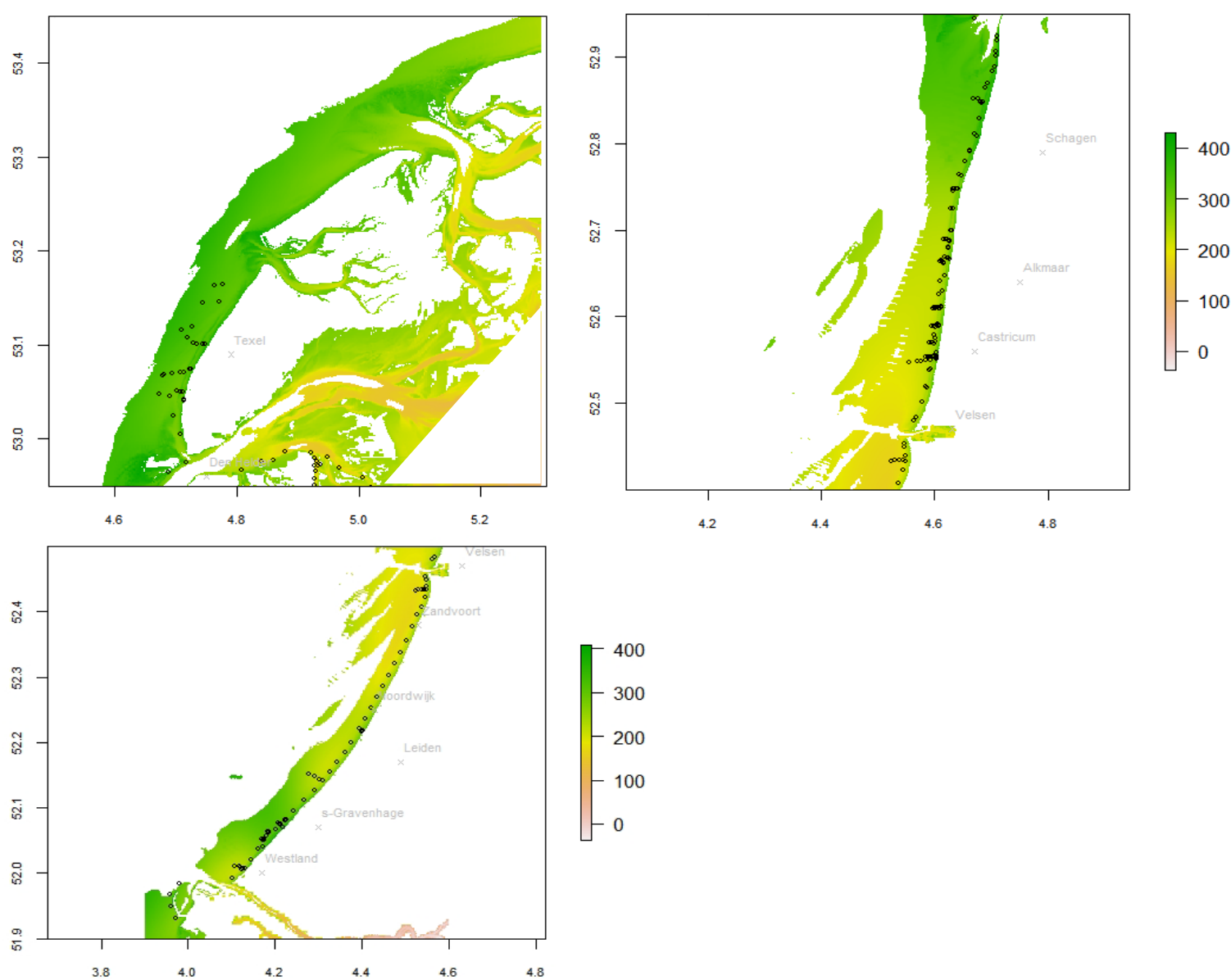

Figuur 5.6 Voorspelde korrelgrootte D50 ( $\mu \mathrm{m})$ op basis van GAM-model, D50 s(diepte)+s(lat,long), gebruikmakend van de volledige dataset van sedimentmonsters verzameld tijdens het veldwerk (open rondjes). 

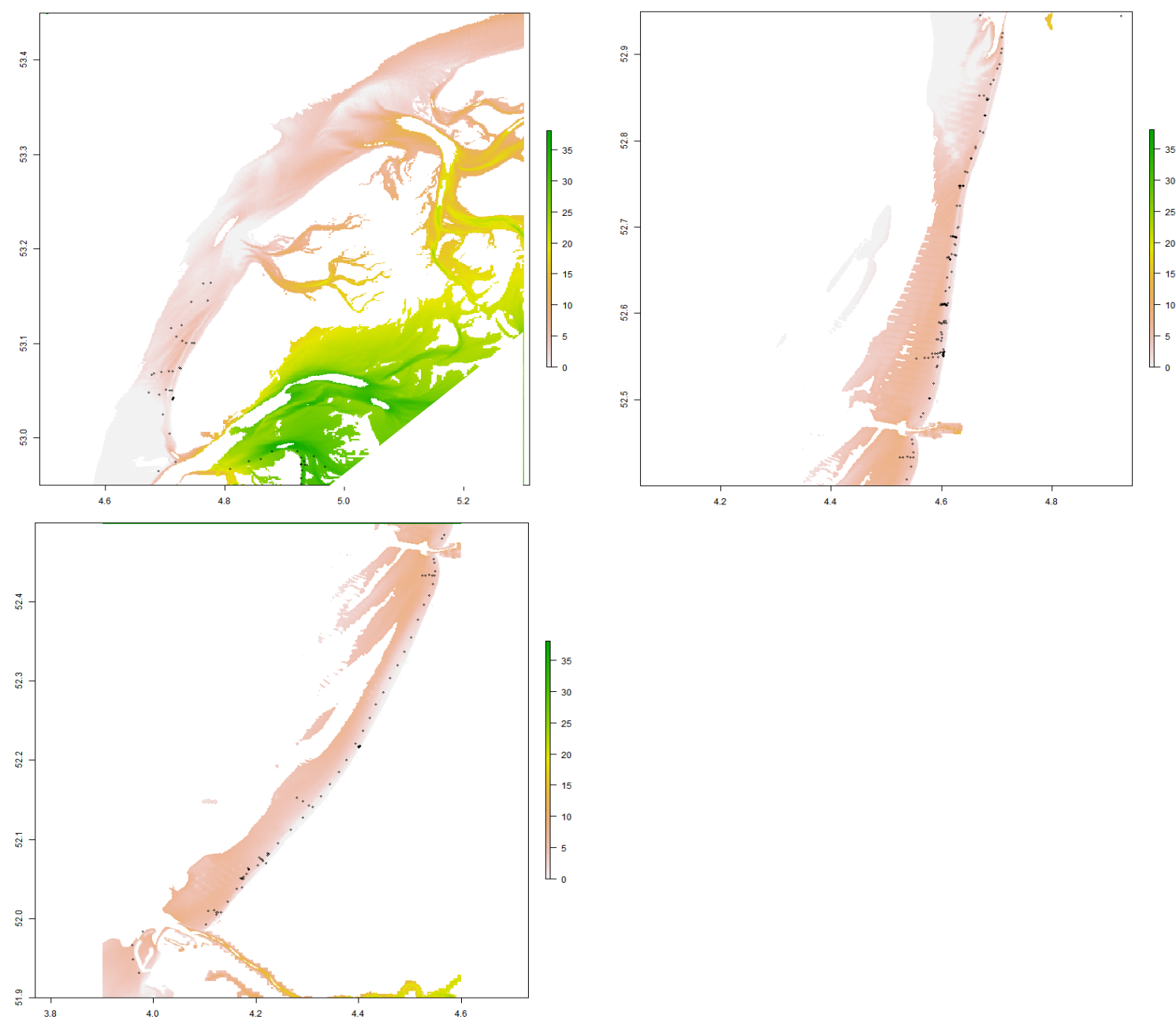

Figuur 5.7 Voorspeld slibgehalte (\%) op basis van GAM-model, Slib s(diepte)+s(lat,long), gebruikmakend van de volledige dataset van sedimentmonsters verzameld tijdens het veldwerk (open rondjes).

\section{$5.4 \quad$ Bodemdieren}

Tijdens de kustvak bemonsteringen in 2017 en 2018, zijn in totaal 106 bodemmonsters genomen, die zijn uitgezocht op de aanwezigheid van bodemdieren. De monsters zijn niet gelijk verdeeld over de verschillende kustvakken en dieptes (Tabel 5.2). Er zijn 25 monsters genomen in kustvak ZuidHolland, 34 in Noord-Holland, 12 op Texel, 8 op Ameland en 28 op Schiermonnikoog. De bodemdieren konden niet allemaal op soort gebracht worden, in dat geval werden ze geregistreerd op een hoger niveau (genus, subfamilie, familie). Er zijn in totaal 96 verschillende soorten geregistreerd, daarnaast zijn er nog 56 verschillende hogere niveaus geregistreerd.

$\mathrm{Er}$ is een duidelijk verschil tussen de Schiermonnikoog monsters uit 2018 en de overige kustvakken uit 2017. De aantallen aangetroffen bodemdieren in de monsters van Schiermonnikoog waren veel hoger dan in de monsters uit 2017, 71\% van het totaal aantal bodemdieren aangetroffen werd aangetroffen in de monsters van Schiermonnikoog. De dominante soorten in de Schiermonnikoog monsters waren juveniele Ensis sp. ( $98 \%$ van alle Ensis werd aangetroffen in de monsters van Schiermonnikoog), het goudkammetje (Lagis koreni, 99\%), Magelona sp./Magelona johnstoni ( $\sim 66 \%$ ) en de borstelworm Owenia borealis ( $~ 93 \%)$.

In de monsters van Zuid-Holland, Noord-Holland en Texel was de borstelworm Magelona johnstoni de dominante soort. Deze werd in Noord-Holland gevolgd door het nonnetje (Limecola balthica), in ZuidHolland door de borstelworm Spiophanes bombyx en bij Texel door het bulldozerkreeftje (Urothoe poseidonis). In het beperkt aantal monsters bij Ameland waren de schelpkokerworm (Lanice conchilega), Magelona johnstoni en de halfgeknotte strandschelp (Spisula subtruncata) de dominante soorten. Een verdere uitwerking van deze gegevens is gegeven in (Herman e.a., 2021).

Ook uit bijna alle vangsten met de vistuigen zijn bodemdieren, garnalen, kwallen en inktvissen geregistreerd (Bijlage 2). De determinatie van deze soorten is geen prioriteit tijdens de bemonstering 
en is beperkt tot het niveau van genus/familie. De registratie van kleine exemplaren $<1 \mathrm{~cm}$ is niet consistent. Desondanks zijn er 50 unieke soorten en 20 hogere niveaus geregistreerd. Gewone garnaal (Crangon crangon) was in alle gebieden de dominante soort in de vangsten. Andere veel gevangen soorten waren de zwemkrabben (Liocarcinus sp.), de strandkrab (Carcinus maenas) en de kleine heremietkreeft (Diogenes pugilator). Daarnaast werden grote hoeveelheden kwallen geregistreerd, o.a. zeedruif (Pleurobrachia pileus), Amerikaanse ribkwal (Mnemiopsis leidyi), oorkwal (Aurelia aurita) en haarkwallen (Cyanea sp.). De ruimtelijke verspreiding van de gewone garnaal, zwemkrab, strandkrab en kleine heremiet is weergegeven in Figuur b 1. De eerste drie zijn vooral gevangen ten noorden van IJmuiden, en werden in lagere aantallen gevangen in het kustvak Zuid-Holland. De gewone garnaal en de strandkrab werden ook in hoge aantallen aangetroffen in de trekken in de Waddenzee. De kleine heremiet is vooral gevangen voor het strand van Castricum tot Bergen aan Zee en Texel en in lagere aantallen in het kustvak Zuid-Holland. Ze werden nauwelijks aangetroffen ten noorden van Bergen aan Zee tot aan Den Helder en helemaal niet in de Waddenzee.

Een deel van deze soorten is interessant in relatie tot de habitatkwaliteit van juveniele (plat)vis. Een aantal in de vorm van voedsel, een ander deel als predator en sommige zoals de gewone garnaal als beide (Gibson e.a., 1995).

\subsection{Zoöplankton}

Noctiluca scintillans was zowel in 2017 als in 2018 verreweg de meest dominante soort in alle zoöplanktonmonsters, met een 10 tot 50 keer hogere abundantie dan alle andere taxa samen. In 2017, werden naast $N$. scintillans vooral calanoide roeipootkreeftjes (met name Temora, Centropages, Acarcia en Paracalanus) waargenomen, en bevatte de monsters ook Appendicularia, Cladocera, en Bivalvia en Polychaeta larven (Figuur 5.8).
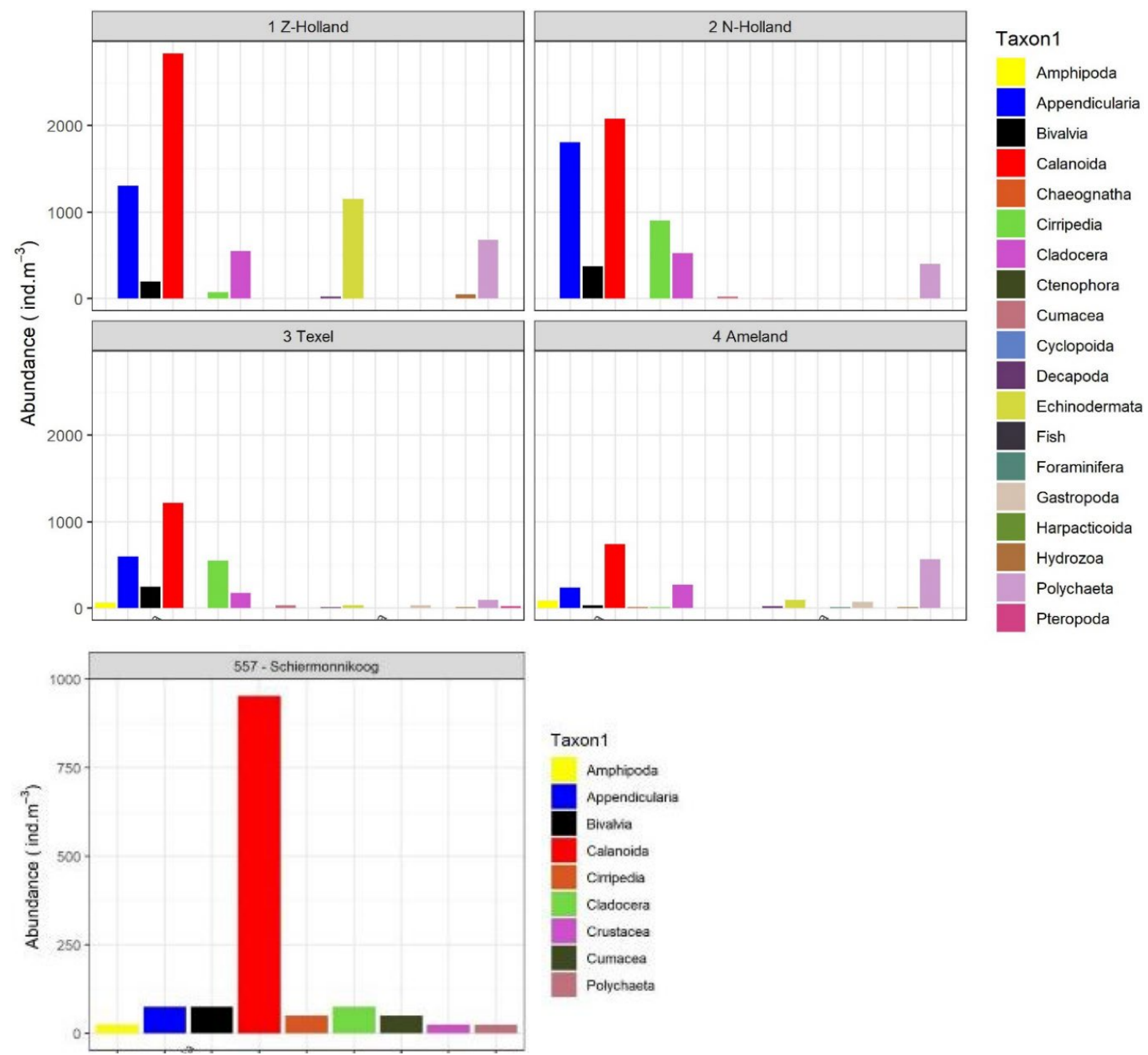

Figuur 5.8 De samenstelling van de zoöplanktonmonsters per kustvak (Couperus e.a., 2020), met uitzondering van de meest dominante soort Noctiluca scintillans. 
Ruimtelijke verschillen waren zichtbaar, met grote aantallen larven van stekelhuidigen in het kustvak Zuid-Holland terwijl deze beperkt werden aangetroffen in de andere gebieden. In de kustvakken Noord-Holland en Texel werden Cirripedia in grotere aantallen aangetroffen.

\subsection{Demersale vis}

In de Natuurlijk Veilig bemonstering gericht op demersale vis zijn 50 soorten aangetroffen, waarvan er 12 beschouwd worden als pelagische soorten (Bijlage 1). Dit zijn dezelfde soorten als aangetroffen in vergelijkbare bemonsteringen in de vooroever (Tulp e.a., 2006; Holzhauer e.a., 2014). De overgrote meerderheid van de vangst bestond uit kleine vis $(<20 \mathrm{~cm}$, Figuur 5.9). De vissen in de ondiepste zone $(<1 \mathrm{~m})$ waren kleiner dan die in de overige dieptes. De gebruikte tuigen, de beperkte vissnelheid en trekduur zijn gericht op het vangen van kleine vis, en zorgen voor een lagere vangstefficiëntie voor grote vis (Kuipers, 1975). De lengte-frequentieverdeling is daardoor geen absolute afspiegeling van de vislengtes in de vooroever.
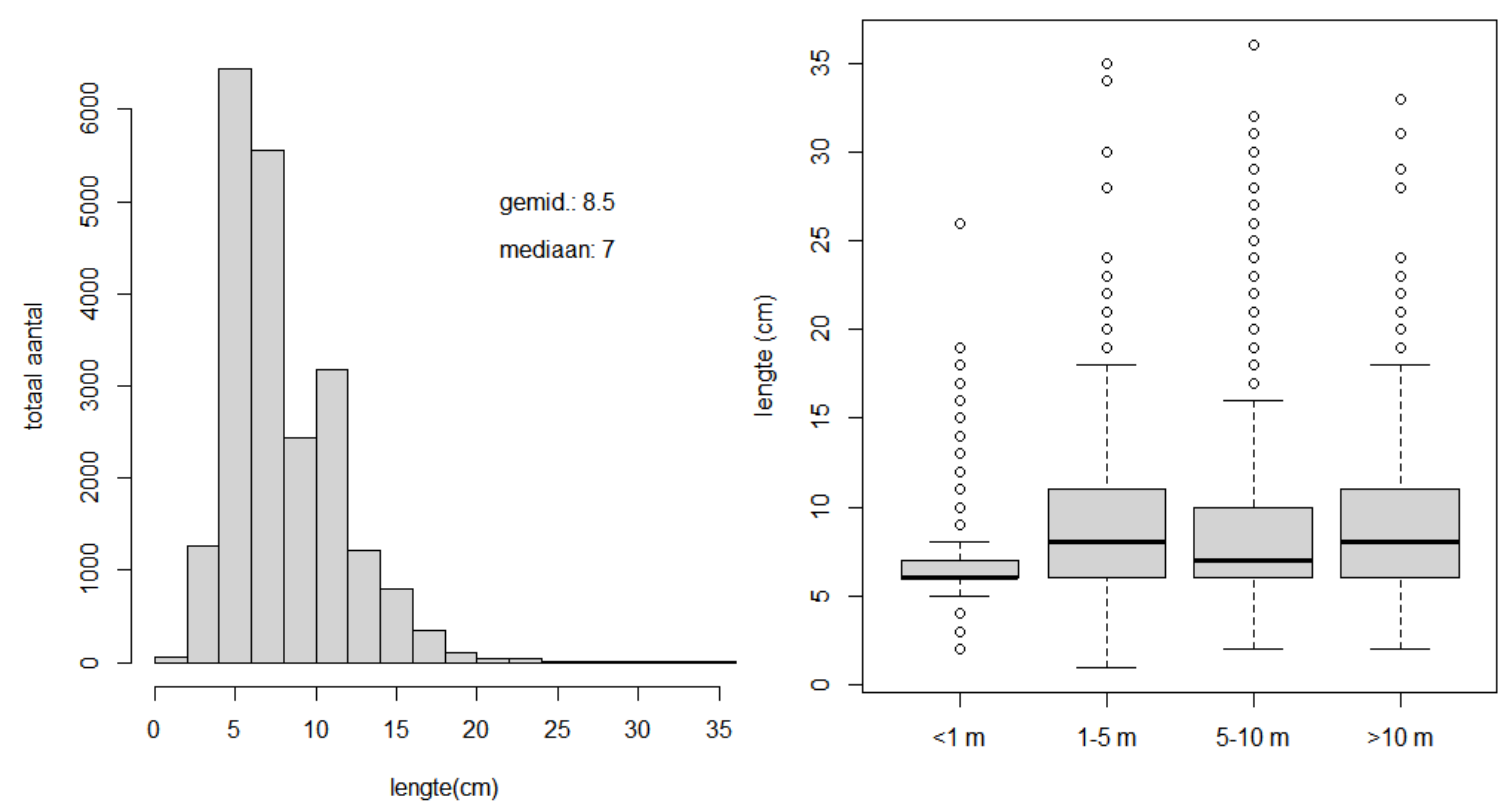

Figuur 5.9 Links: de lengteverdeling van de demersale vis gevangen in alle bemonsteringen binnen Natuurlijk Veilig. Rechts: de lengteverdeling van de demersale vis per diepteklasse in de maanden juni/juli.

\subsubsection{Kustvakken}

\subsubsection{Visgemeenschap}

De bemonstering van de kustvakken was gericht op het analyseren van ruimtelijke verschillen in de aanwezigheid van juveniele vis en deze te koppelen aan de lokale omstandigheden in de vooroever. Het bemonsteren van verschillende dieptes in de vooroever vereist verschillende bemonsteringsmethodes ieder met zijn eigen vangstefficiëntie. De vangstgegevens van de methodes combineren in analyses is lastig door het onbekende verschil in vangstefficiëntie en het ontbreken van overlap in bemonsteringslocaties. Het combineren van alle vangsten wordt verder bemoeilijkt doordat de ondiepe bemonsteringen in de kustvakken Texel en Ameland niet konden worden uitgevoerd.

In het kustvak Zuid-Holland, het gebied rondom de Zandmotor, is significant minder vis gevangen vergeleken met de andere gebieden, ook als de eerste vier Luctor trekken zonder wekkerketting niet worden meegenomen (Figuur 5.10, Bijlage 5). Een vergelijkbare bemonstering, met een grotere maaswijdte van $20 \mathrm{~mm}$ uitgevoerd eind zomer-begin najaar in het kader van de aanleg van de Zandmotor (2011-2013, 2015 (Wijsman e.a., 2015)), resulteerde in hogere aantallen vis, met mediane waardes vergelijkbaar met die van de andere kustvakken en maximale waardes ver boven die van de Natuurlijk Veilig bemonstering (Bijlage 3). 
Op basis van gewicht (de aan boord bepaalde natgewichten en waar deze ontbreken de berekende gewichten $(\mathrm{W}=\mathrm{L} \wedge 3)$ ) verschuiven de verhoudingen tussen de kustvakken. De vangsten in ZuidHolland waren in gewicht vergelijkbaar met die in Noord-Holland en Schiermonnikoog. Terwijl op basis van gewicht Texel en in iets mindere mate Ameland hoger waren. Dit is een aanwijzing dat de gevangen vissen in Zuid-Holland, Texel en Ameland groter waren dan in de andere gebieden.
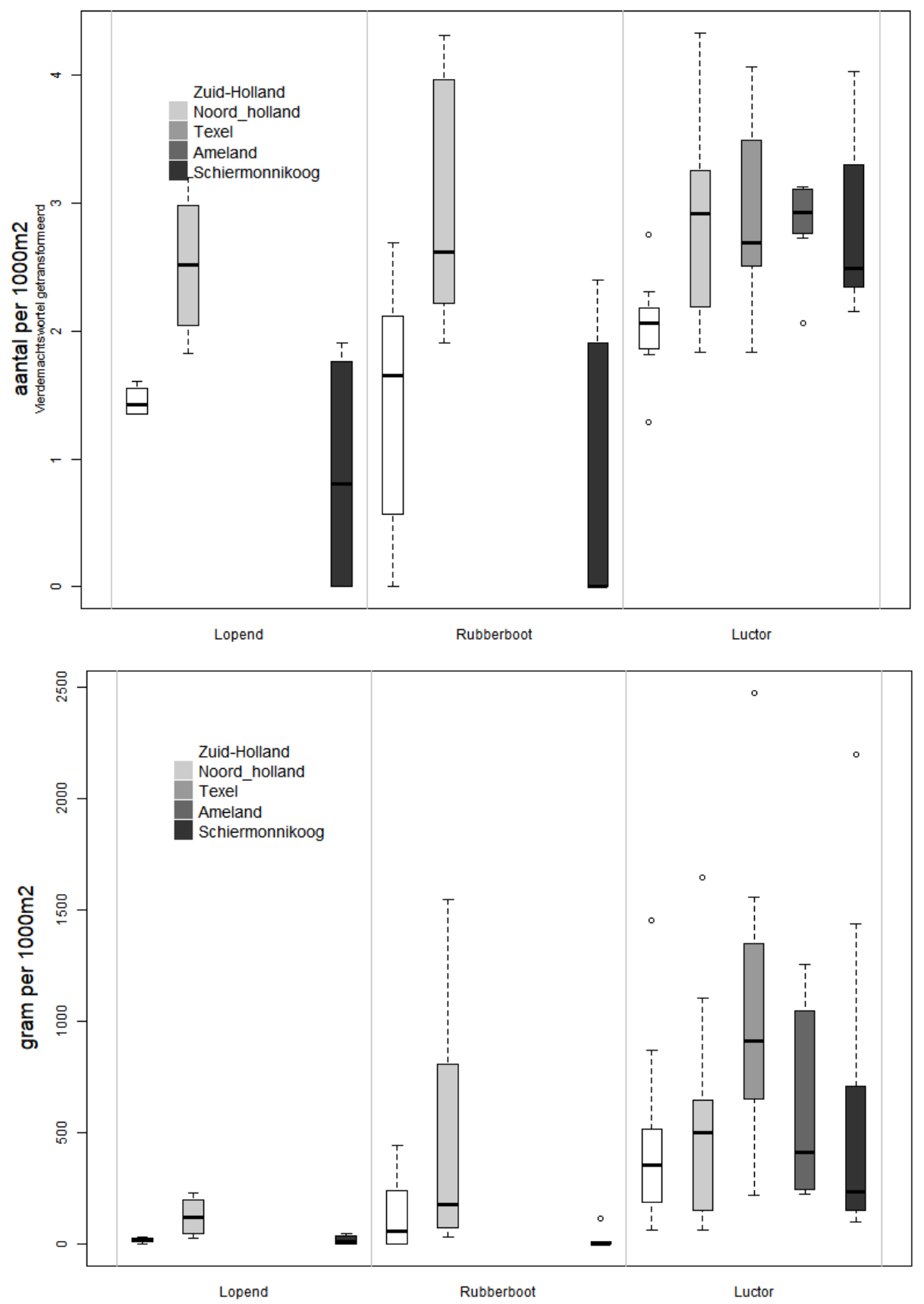

Figuur 5.10 Totaal aantal (vierdemachtswortel getransformeerd) en totaalgewicht demersale vis per $1000 \mathrm{~m}^{2}$ per kustvak en bemonsteringsmethode.

In de ondiepste zones werden in Noord-Holland grote aantallen vis gevangen. Dit is hoogst waarschijnlijk het resultaat van het gunstige weer in die week, waardoor de bemonsteringen zonder problemen konden worden uitgevoerd, ten opzichte van het weer tijdens de bemonsteringen bij ZuidHolland en Schiermonnikoog. Een werkelijk verschil in de aanwezigheid van de hoeveelheid vis is echter niet uit te sluiten.

De vangstsamenstelling van de demersale vis vertoont overlap tussen de verschillende kustvakken (Figuur 5.11). De meerderheid van de monsters uit kustvak Zuid-Holland liggen op de eerste as van de PCA verder naar links met maar beperkte overlap met de monsters uit Ameland. Deze scheiding 
wordt met name bepaald door de aanwezigheid van kleine pieterman, smelt en griet in de vangst van Zuid-Holland, en maar beperkte aanwezigheid van schol en harnasmannetje.

De monsters met lage vangsten genomen vanaf het strand worden duidelijk gegroepeerd op basis van diepte. Al is er wel overlap met monsters uit de diepteklassen 1-5 m en 5-10 m. Op de tweede-as van de PCA worden met name de diepste monsters (>10 m) gescheiden van veel van de andere monsters. Dit is gebaseerd op de aanwezigheid van soorten als schurftvis, dwergtong en schar en in verhouding minder tong, dwergbolk en kleine zeenaald.

Niet op alle locaties waren sedimentmonsters genomen, derhalve de categorie NA in de groepering op basis van D50, de vangsten in een aantal van deze locaties zijn duidelijk uitschieters. Mogelijk zijn dit de vangsten genomen tijdens de lastigere omstandigheden, vanuit de rubberboot in de brandingszone of vanaf de Luctor tijdens hogere golfhoogtes waardoor op dat moment het nemen van sedimentmonsters niet mogelijk was en de vangstefficiëntie van het vistuig was afgenomen. Verder suggereert de D50 geen duidelijke groepering op basis van soortsamenstelling.
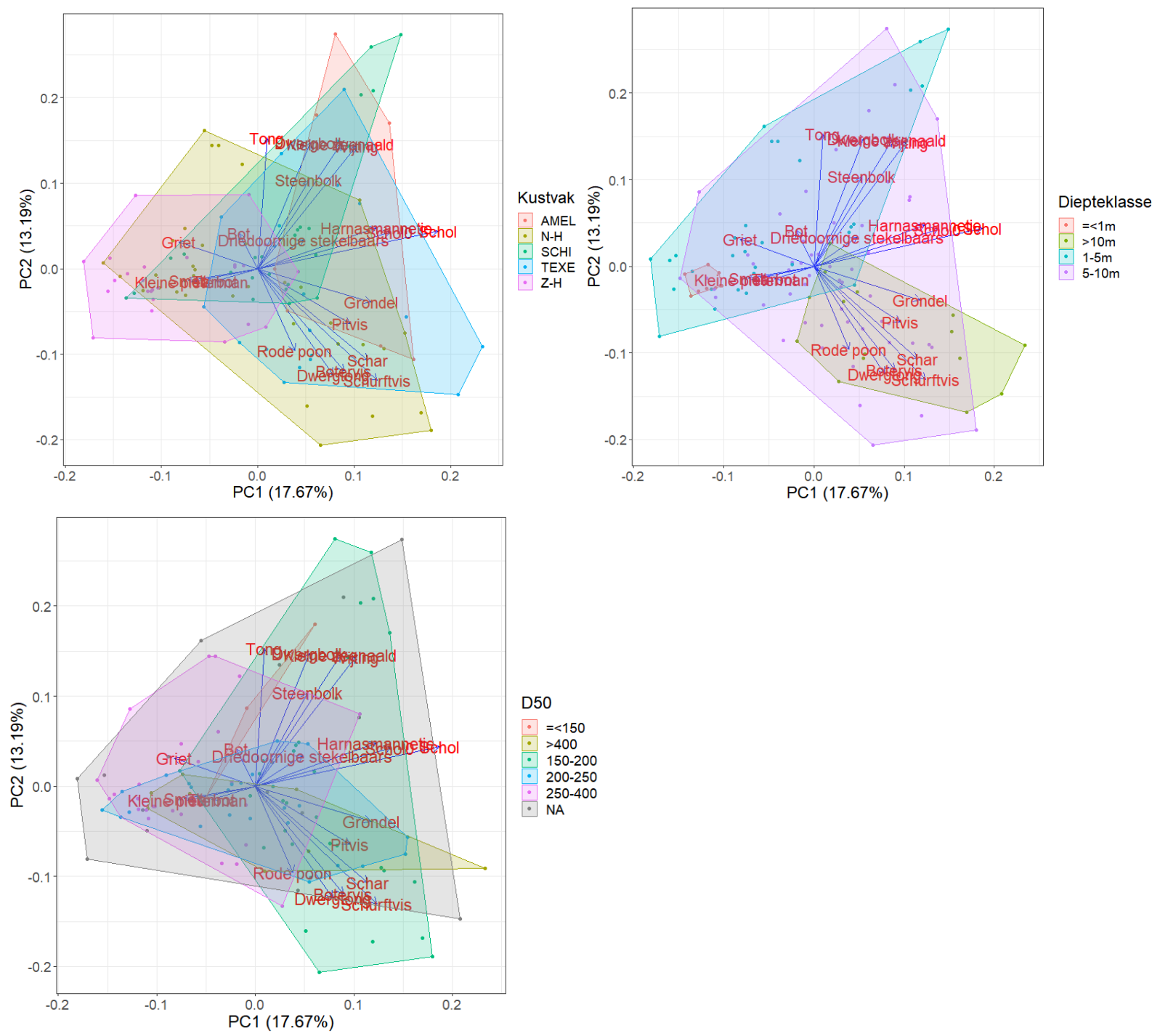

Figuur 5.11 Visuele weergave van de eerste twee assen van de Principale Componenten Analyse (PCA), groepering gebaseerd op Kustvak, diepteklasse, korrelgrootte (D50). In de D50-plot staat $N A$ voor de monsters waarvoor geen sedimentmonsters verzameld zijn.

\subsubsection{Schol}

De doelsoort en meest gevangen demersale vissoort was schol. De mediane lengte van schol in de vangsten in water $<1 \mathrm{~m}$ diep was kleiner dan die in de andere diepteklassen (Figuur 5.12). Dit was vooral een gevolg van het ontbreken van grotere vis, $>8 \mathrm{~cm}$, in deze vangsten. In water dieper dan 1 $\mathrm{m}$ werden schollen van vergelijkbare lengtes gevangen met een mediane lengte van $\sim 7,5 \mathrm{~cm}$. Het overgrote deel van de gevangen schol was kleiner dan $9 \mathrm{~cm}$ en dus 0-jaar gezien ze gevangen waren in juni/juli. Dit zijn dus schollen die zich eerder in het voorjaar als larve in de omgeving hebben 
gevestigd. Dezelfde lengtemetingen maar dan ingedeeld per kustvak, duiden op eenzelfde lengte voor schol in alle kustvakken (Figuur 5.12).
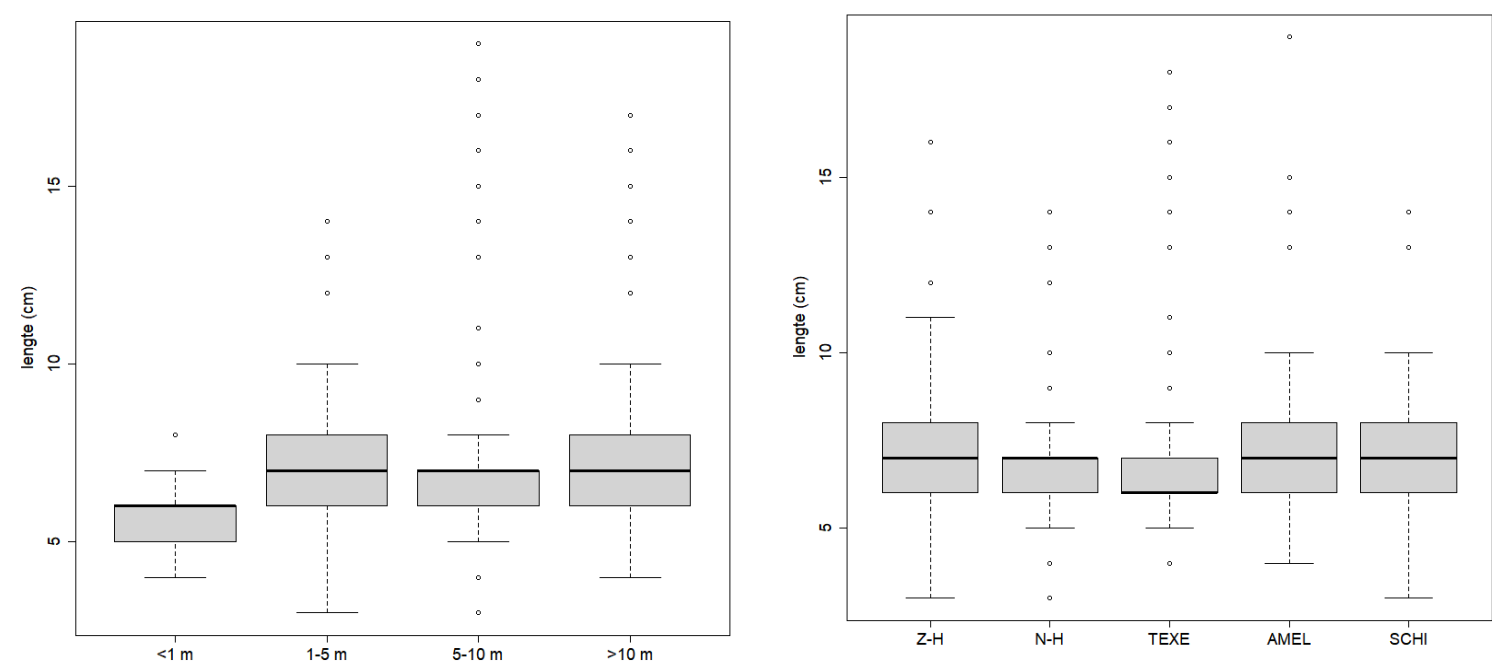

Figuur 5.12 Lengtes van schol uit de vangsten van de kustvakbemonsteringen 2017, 2018 per diepteklasse en kustvak.

Individueel gewicht is bepaald van een groot deel van de gevangen schol (>1 gram). Op basis van deze individuele gewichten is de Fulton's k conditiefactor berekend. De gemiddelde conditiefactor is vergelijkbaar tussen de kustvakken, met een iets slechtere conditie in het kustvak Texel en een iets betere conditie in kustvak Schiermonnikoog in 2018 (Figuur 5.13).

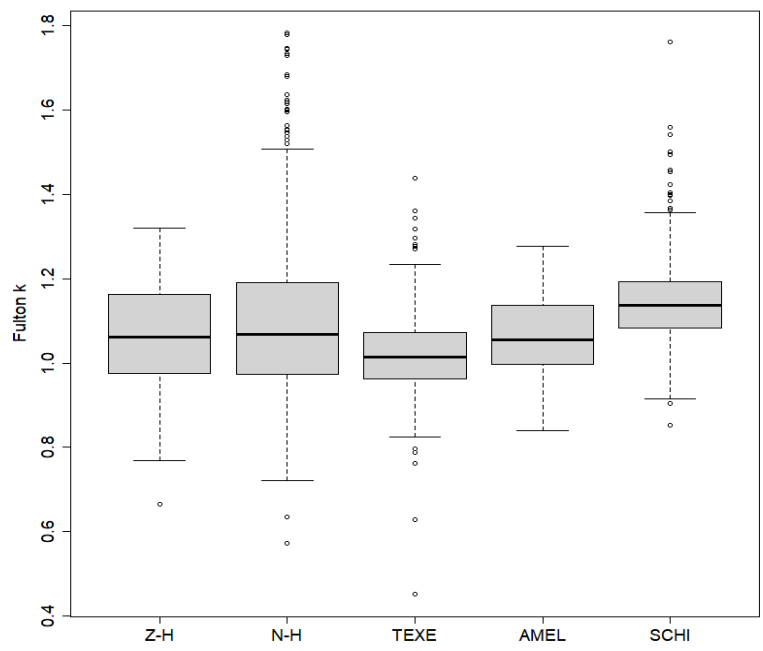

Figuur 5.13 Fulton's $k$ conditiefactor van schol uit de vangsten van de kustvakbemonsteringen 2017, 2018 per kustvak.

De aantallen schol per trek (Figuur 5.14) laten een vergelijkbaar beeld zien als de gehele vangst (Figuur 5.10), waarmee duidelijk is dat schol in aantallen de dominantste soort was. Ten opzichte van het figuur voor de gehele vangst, liggen de aantallen schol in Zuid-Holland en Ameland in verhouding nog lager. Met name bij Ameland zijn er naast schol veel andere soorten gevangen. Dat de gevangen schol in alle gebieden nagenoeg dezelfde lengte en daarmee gewicht heeft resulteert erin dat het figuur op basis van gewicht zeer vergelijkbaar is met die op basis van aantallen. De verschillen tussen aantal en gewicht in Figuur 5.10 werden dus vooral veroorzaakt door andere soorten dan schol. De dichtheden bij Schiermonnikoog in 2018 waren vergelijkbaar met de dichtheden bij Noord-Holland en Texel terwijl de 2018 jaarklasse van schol een enorme positieve uitschieter is de langjarige tijdserie (ICES, 2020). Mogelijk resulteerde dit niet meteen in hogere dichtheden, maar maakte die jaarklasse gebruik van een veel groter gebied als kinderkamer, aangezien de 0-groep schol in de zomer in hoge dichtheden werd aangetroffen buiten de reguliere kinderkamers (de Boois e.a., 2018). 

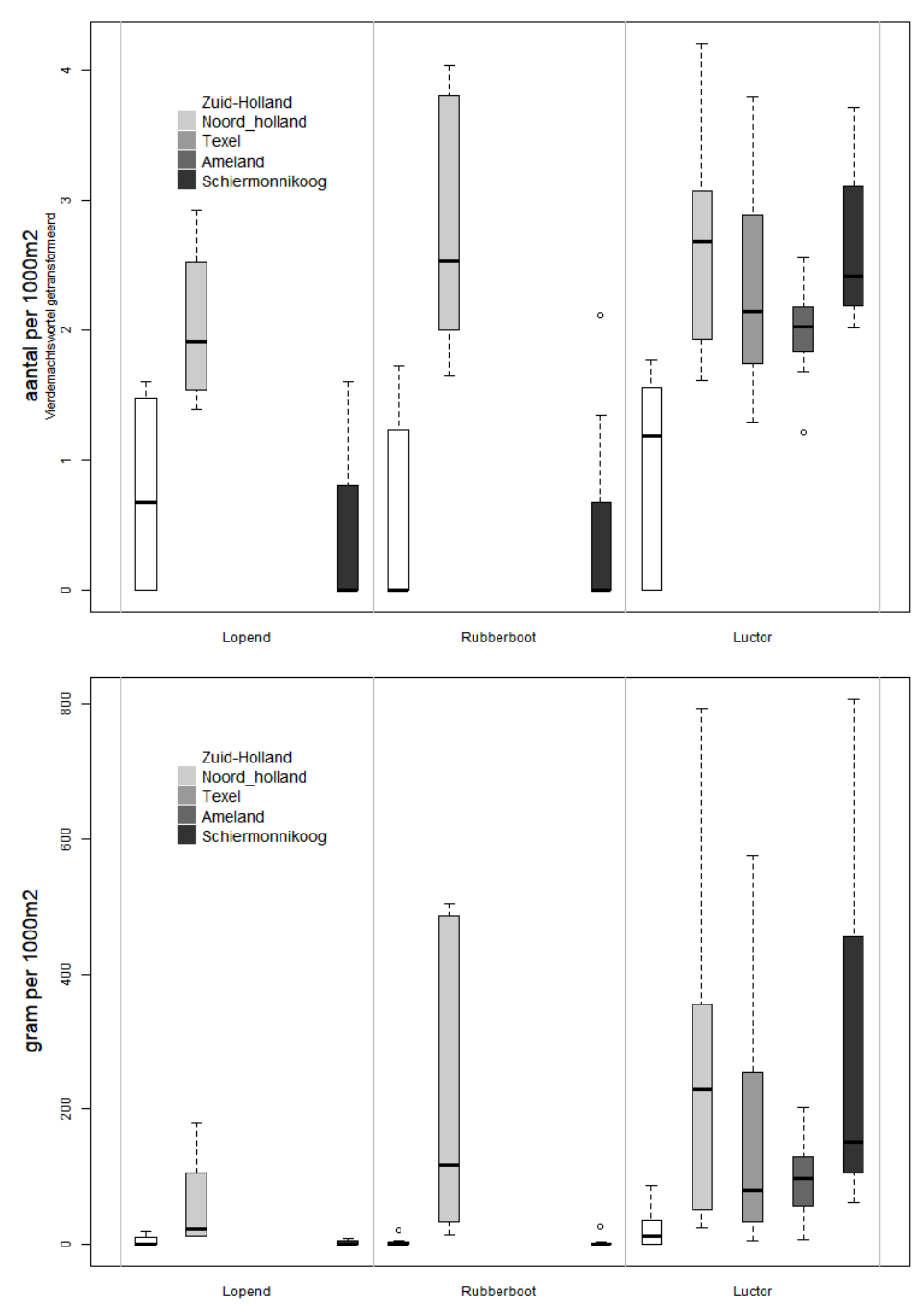

Figuur 5.14 Totaal aantal (vierdemachtswortel getransformeerd) en totaalgewicht schol per 1000 $m^{2}$ per kustvak en bemonsterings-methode.

\subsubsection{Tong}

Tong is in veel lagere aantallen gevangen dan schol (Bijlage 1) en helemaal niet gevangen in de ondiepe trekken bemonsterd vanaf het strand (Figuur 5.16). In de trekken uitgevoerd in water dieper dan $10 \mathrm{~m}$ werden tongen van rond de $15 \mathrm{~cm}$ aangetroffen. Dezelfde lengtes werden ook een enkele keer gevangen op een diepte van 1-10 m, maar hier werden vooral tongen kleiner dan $5 \mathrm{~cm}$ gevangen (Figuur 5.15). Die laatste zijn 0 -jarige kortgeleden als larven aangekomen in dit gebied.
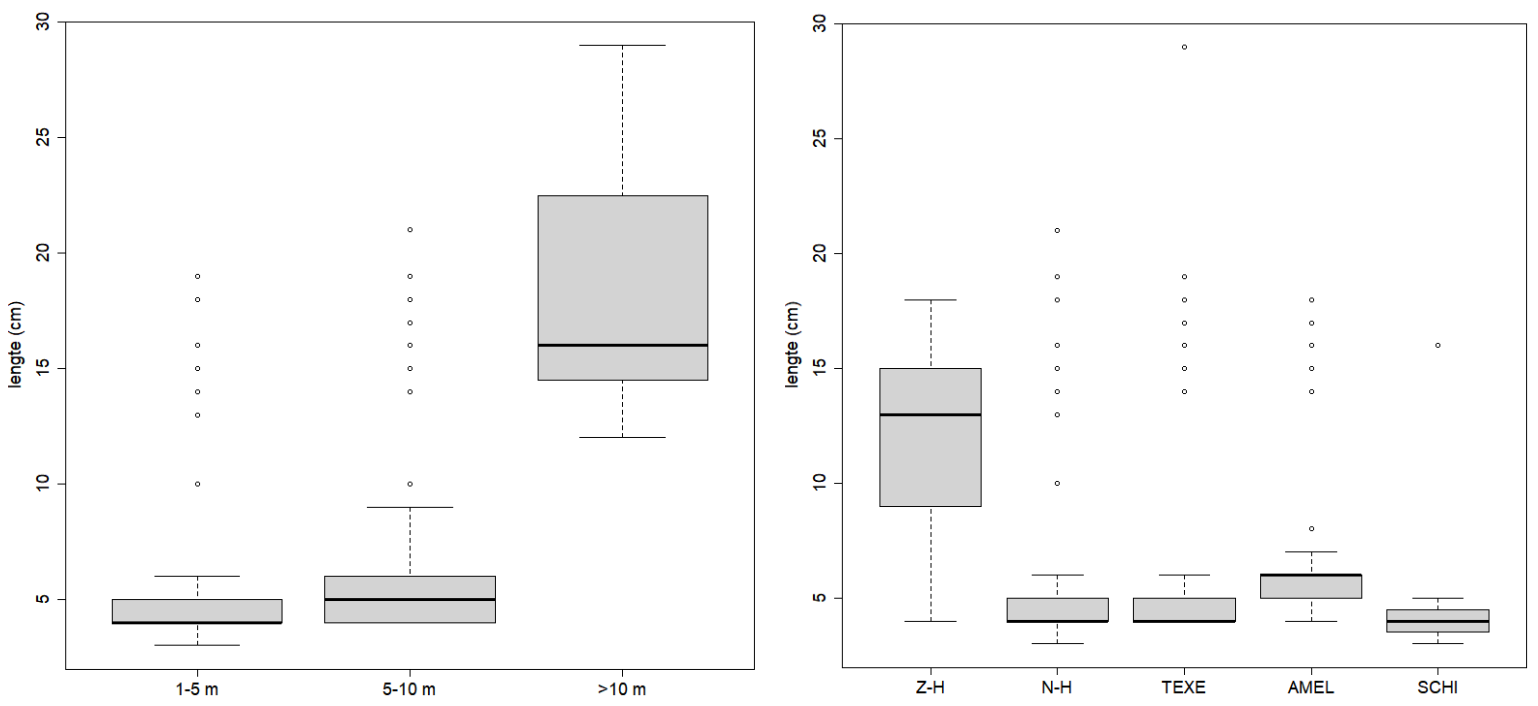

Figuur 5.15 Lengtes van tong uit de vangsten van de kustvakbemonsteringen 2017, 2018 per diepteklasse en kustvak. 
De aantallen per bemonsteringsmethode en kustvak (Figuur 5.16), laten vooral zien dat tong in een beperkt aantal trekken in grote aantallen is aangetroffen. In totaal is tong in 34 (waarvan 8 rubberboot) van de 123 trekken aangetroffen. De grootste vangsten werden gedaan vanuit de rubberboot in het kustvak Noord-Holland.

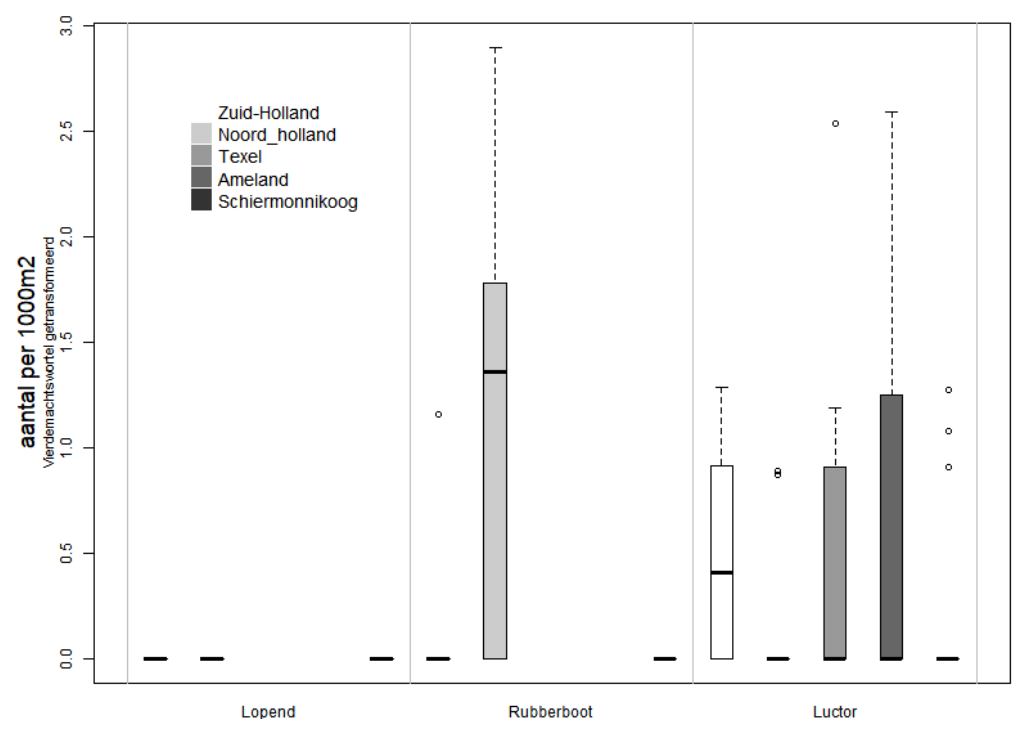

Figuur 5.16 Totaalaantal tong per $1000 \mathrm{~m}^{2}$ (vierdemachtswortel getransformeerd) per kustvak en bemonsteringsmethode.

\subsubsection{Tarbot en griet}

Er zijn slechts negen tarbotten gevangen in de kustvakbemonsteringen, waarvan één vanuit de rubberboot en de andere vanaf de Luctor. Drie waren er gevangen bij Texel, de andere zes bij ZuidHolland. De tarbot gevangen vanuit de rubberboot was $1,9 \mathrm{~cm}$ en dus niet lang daarvoor aangekomen als larve. De overige waren 11-18 cm en waarschijnlijk 1 jaar oud (van Leeuwen en Rijnsdorp, 1986). Eén tarbot van $30 \mathrm{~cm}$ werd gevangen.

Er zijn 26 grieten gevangen, waarvan vier in de ondiepste zone $<1 \mathrm{~m}$. Deze vier hadden een lengte tussen de 2-3 cm en waren dus 0 jaar. Er werd ook een griet van $2 \mathrm{~cm}$ gevangen in de dieptezone 5$10 \mathrm{~m}$. Alle andere griet op deze diepte was $11-29 \mathrm{~cm}$ (Figuur 5.17). Griet is gevangen vanaf het strand of met de rubberboot bij Noord-Holland, terwijl ze bij Zuid-Holland zijn gevangen vanaf de Luctor. In de andere kustvakken werd geen griet gevangen.

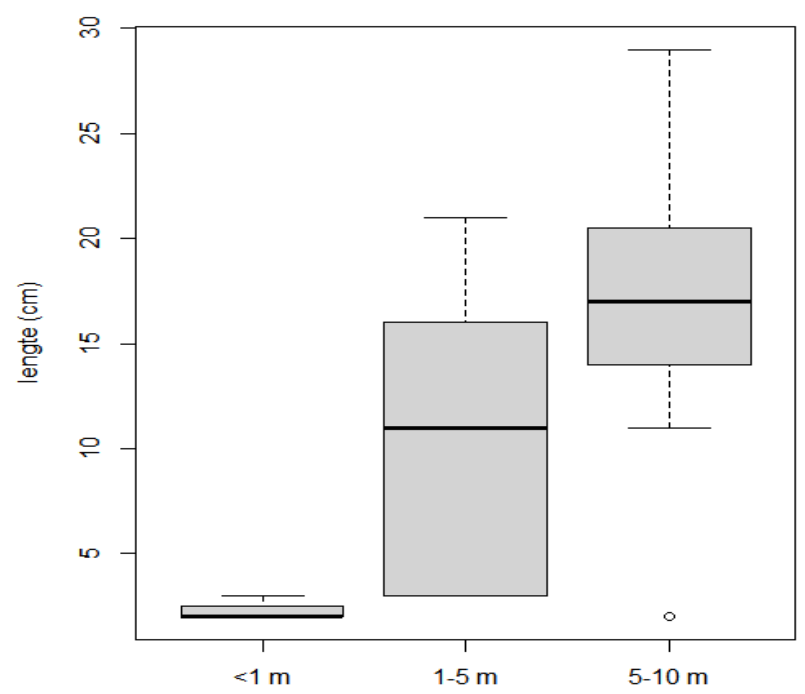

Figuur 5.17 Lengtes van griet uit de vangsten van de kustvakbemonsteringen 2017, 2018 per diepteklasse. 


\subsubsection{RNA:DNA-ratio's}

In 2017 zijn als studentenonderwerp uit de vier kustvakken schol (392), tong (79), schar (303), tarbot (7) en griet (19) verzameld voor verdere analyse op het lab (Rutting, 2017). De vissen over het gehele lengtebereik zijn verzameld uit alle trekken verspreid over de dieptes. In het lab is de ratio tussen het RNA en DNA van ieder individu bepaald. De RNA:DNA-ratio is een maat voor de recente groei, waarbij de aanname is dat de hoeveelheid RNA gecorreleerd is met eiwitsynthese terwijl de hoeveelheid DNA gelijk blijft.

De gemiddelde ratio's verschillen in sommige gevallen significant tussen de kustvakken (Figuur 5.18). Correlaties met verschillende variabelen laten zien dat de ratio's mogelijk worden beïnvloed door o.a. waterdiepte, moment van de dag waarop ze zijn bemonsterd en de lengte van de vis. De omstandigheden waaronder de vissen zijn verzameld in de verschillende kustvakken zijn niet gelijk, en daardoor zijn de verschillen in Figuur 5.18 niet rechtstreeks te interpreteren.
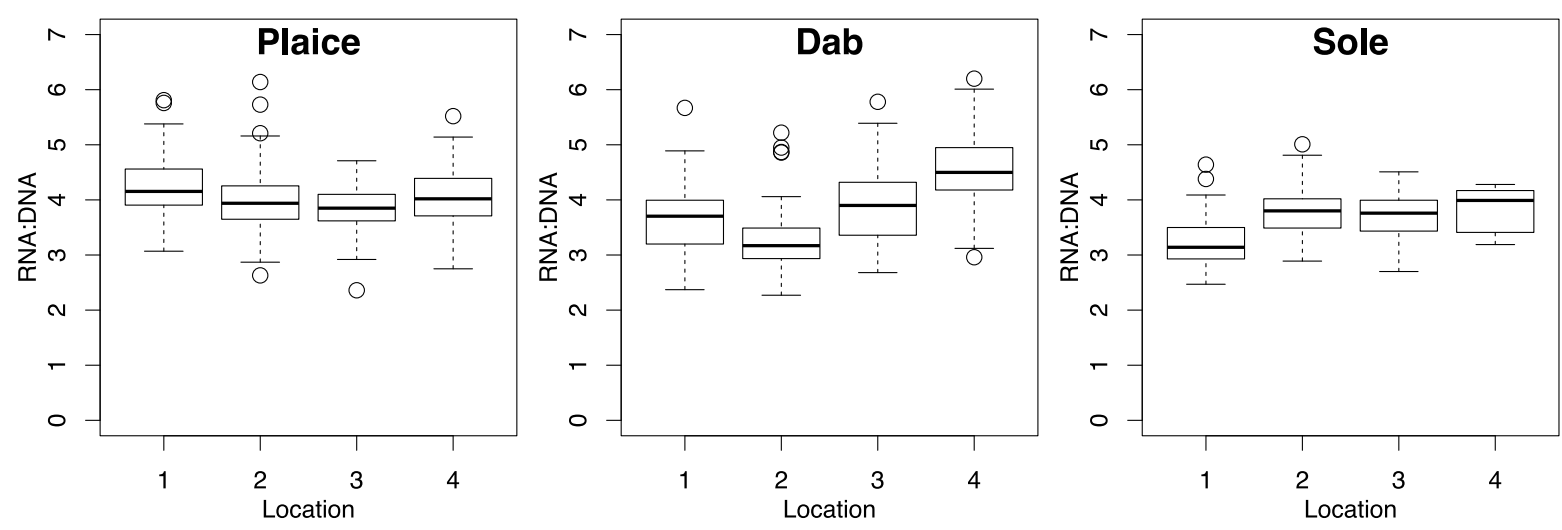

Figuur 5.18 Gemiddelde RNA:DNA-ratio voor schol, schar en tong per gebied. $1=$ Zuid-Holland, 2= Noord-Holland, 3=Texel, 4= Ameland.

Uitgebreidere analyses resulteerde in geen significante verschillen tussen de verschillende kustvakken voor schol en tong. Alleen voor schar bleven er significante verschillen tussen de gebieden, hierin speelde de groei van schar in de vier weken waarin de bemonsteringen waren uitgevoerd een rol. Er is een toename in lengte van 0-groep schar in de opeenvolgende kustvakken zichtbaar die waarschijnlijk een gevolg van groei over de tijd is en niet van een verschil in habitatkwaliteit. Er is een duidelijk relatie tussen de RNA:DNA-ratio's en de lengte van de 0-groep schar. Op dezelfde manier is ook het zoutgehalte gecorreleerd aan de ratio's voor 0-groep schar, aangezien er een toename in zoutgehalte is tussen de verschillende kustvakken. De invloed van de verschillende gecorreleerde omgevingsvariabelen op de RNA:DNA-ratio's is niet uit elkaar te halen. De resultaten van instantane groei kunnen daardoor niet eenduidig toegewezen worden aan verschillen in habitatkwaliteit tussen de verschillende gebieden.

\subsubsection{Kustlangse bemonstering}

\subsubsection{Totale visgemeenschap}

De kustlangse bemonstering was opgezet was om een beeld te krijgen van de verspreiding van bodemvis langs de Nederlandse kust, op een diepte van 4-6 m. Aanvullend zijn er enkele raaien naar dieper water bemonsterd om inzicht te krijgen in de invloed van diepte op de verspreiding van vis. De totale vangsten in aantallen demersale vis zijn in beide jaren vergelijkbaar met de vangsten van de Luctor tijdens de kustvakbemonsteringen (Figuur 5.10), waar de mediaan van de vangsten in 2019 iets lager ligt dan die van 2020.

De soortsamenstelling van de vangsten gedaan tijdens de kustlangse bemonstering wordt op de eerste as van de PCA gescheiden op basis van de aanwezigheid van smelt, ten opzichte van de aanwezigheid van alle andere soorten. Op de tweede as, is zichtbaar dat de samenstelling van de vangst gevangen in de Waddenzee, Balgzand/Amsteldiep, afwijkt van de vangst in de andere gebieden (Figuur 5.19). De vangst in het Amsteldiep bestond in eerste instantie uit veel zeesla, waartussen vooral kleine tong ( $75 \%$ van alle tong gevangen in de bemonstering van 2020, Bijlage 1) werd aangetroffen. Daarnaast zorgt de aanwezigheid van vijfdradige meun (Ciliata mustela) ( $81 \%$ van alle vijfdradige meun gevangen in de bemonstering van 2020) voor een verschil met de andere gebieden. 
De trekken uitgevoerd in de Waddenzee, Malzwin, overlappen in vangstsamenstelling met de trekken uit de vooroever. Als de monsters worden opgedeeld op basis van D50 overlappen de vangstsamenstellingen uit alle sedimentklassen met elkaar.
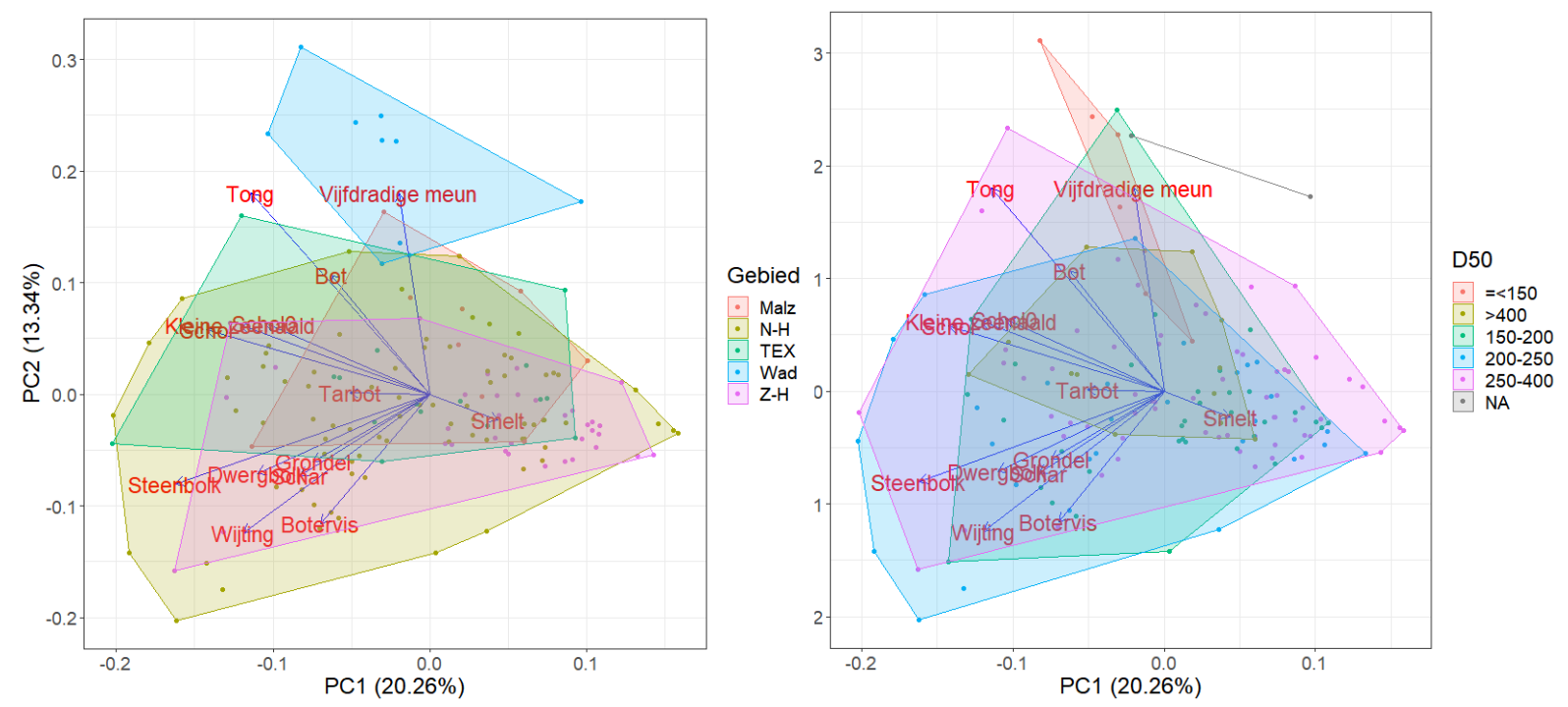

Figuur 5.19 Visuele weergave van de eerste twee assen van de Principal Component Analyse (PCA), groepering gebaseerd op gebied (Malz=Malzwin, $N-H=$ Noord-Holland $>52.43$, Tex=Texel >52.96; Wad= ondiepe trekken Balgzand/Amsteldiep; Z-H= Zuid-Holland <52.43, en korrelgrootte (D50). In de D50-plot staat NA voor de monsters waarvoor geen sedimentmonsters verzameld zijn (twee locaties op Balgzand).

\subsubsection{Schol}

In tegenstelling tot de resultaten uit de kustvakbemonstering is er in de kustlangse bemonstering een duidelijk verschil in lengtesamenstelling in relatie tot diepte te zien (Figuur 5.20), op de raaien van de kustlangse bemonstering is er gevist in water dieper dan $15 \mathrm{~m}$. In de diepere gebieden ontbreken de kleinste schollen, waarmee duidelijk is dat de vooroever in het voorjaar de kinderkamer van de juveniele schol is en niet maar een deelgebied van een naar dieper water uitstrekkende kinderkamer. Er moet echter wel rekening gehouden worden met het kleine aantal trekken in de diepere gebieden ten opzichte van de ondiepste zone. De onbalans in aantal trekken bepaalt deels ook het figuur van de lengtesamenstelling per gebied, waarin in Zuid-Holland en zeker Noord-Holland veel meer locaties zijn bemonsterd dan in de Waddenzee en voor de kust van Texel. De boxplot van Noord-Holland bestaat uit de gegevens van 2019 en 2020, er is echter nauwelijks verschil tussen de twee jaar. Het figuur laat ook hier het ontbreken van de kleinste schol zien, en dan met name aan de kust van Texel en op het Balgzand. Ondanks deze verschillen is er in de schol waarvoor gewicht bepaald is, geen verschil in conditie te zien tussen de verschillende gebieden.
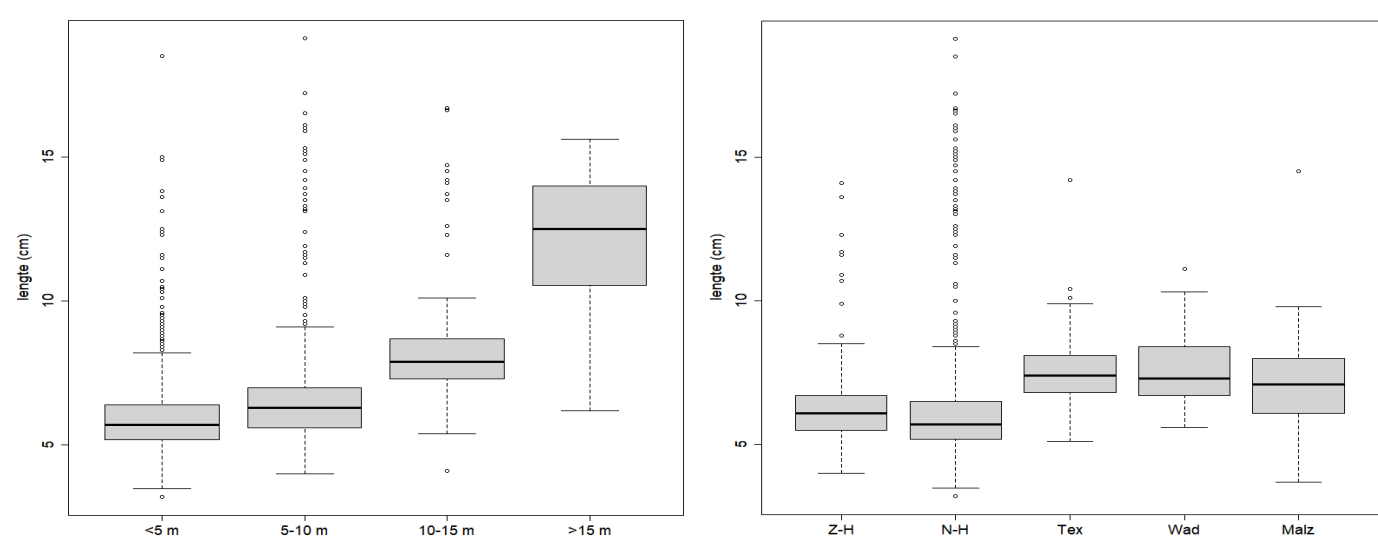

Figuur 5.20 Lengtes van schol uit de vangsten van de kustlangse bemonsteringen 2019, 2020 per diepteklasse en gebied (Z-H: alleen 2019, N-H: 2019+2020; TEX: 2020 en enkele 2019; Wad: 2020; Malz: 2020). 


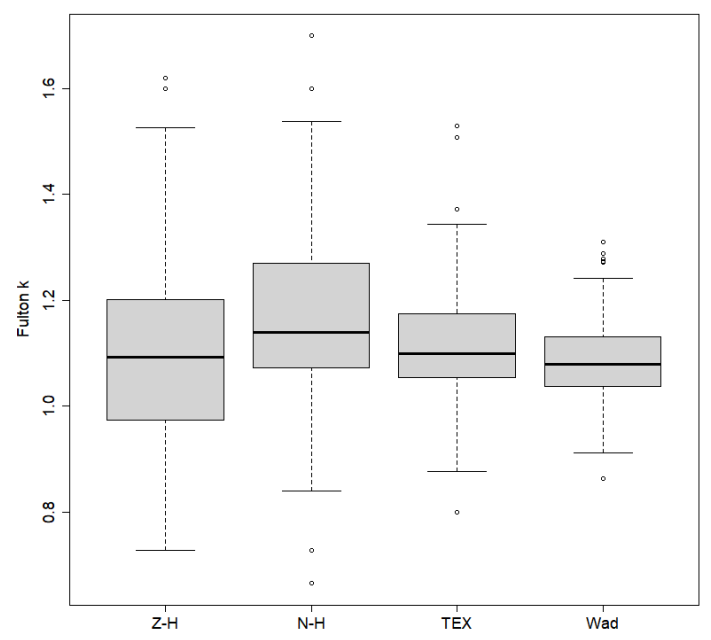

Figuur 5.21 Fulton's $k$ conditiefactor van schol uit de vangsten van de kustlangse bemonsteringen 2019, 2020 gebied (Z-H: alleen 2019, N-H: 2019+2020; TEX: 2020 en enkele 2019; Wad: 2020; Malz: geen gewichten bepaald).

\subsubsection{Habitatmodellering kustvak- en kustlangse bemonstering met de Luctor gecombineerd}

\subsubsection{Schol}

Juveniele schol $(<9 \mathrm{~cm}$ ) werd langs de hele kust inclusief de Waddenzee, afgezien van de meest zuidelijke trekken en in het gebied ter hoogte van Katwijk en Noordwijk gevangen (Figuur 5.22). In totaal is schol in $\sim 86 \%$ van de trekken gevangen. Zoals eerder beschreven is er weinig schol gevangen in het kustvak Zuid-Holland, ook in de kustlangse bemonsteringen (2019) werden hier relatief lage aantallen aangetroffen. Het gebied tussen Den Helder en IJmuiden is in zowel 2017, als 2019 en 2020 bemonsterd. Er is in nagenoeg alle trekken schol gevangen, en in enkele trekken werden grote aantallen juveniele schol gevangen. Ook bij Texel en Schiermonnikoog zijn enkele grote vangsten gedaan. De lagere vangsten in kustvak Zuid-Holland in vergelijking met de vangsten in kustvak Noord-Holland en Texel is vergelijkbaar met die van enkele andere vissoorten (Figuur 5.22, Figuur 5.30) en benthossoorten (Figuur b 1).

De scholvangsten vanaf de Luctor zijn gecorreleerd aan de omgevingsvariabelen sediment, diepte, saliniteit en doorzicht (Secchi-diepte) met behulp van een general addative mixed-model (GAMM), met het jaar waarin de vangsten gedaan zijn als random effect. De resultaten tonen dat saliniteit en doorzicht een significant effect hebben op de hoeveelheid gevangen schol (Figuur 5.23). Bij beperkt doorzicht waren de vangsten hoger, waarbij wel rekening gehouden moet worden dat doorzicht deels gecorreleerd is aan diepte. Echter, waterdiepte is niet significant als deze in plaats van doorzicht wordt meegenomen in de analyses. De relatie betekent waarschijnlijk dat bij beperkt doorzicht schol efficiënter gevangen wordt, en niet dat er dan meer schol aanwezig is.

De relatie met saliniteit suggereert dat er bij lage saliniteit minder schol aanwezig is. Dit zoetere water is te vinden nabij de monding van de Rijn en Maas in het zuiden, waar dus ook de lagere aantallen schol gevangen werden.

Er was geen relatie tussen de hoeveelheid schol en de korrelgroottesamenstelling binnen het bereik van de mediane korrelgroottes $(27-630 \mu \mathrm{m})$ aangetroffen in de vooroever. Ook binnen het bereik aan waterdiepte (2,5-16 m) lijkt er geen relatie met de dichtheden van juveniele schol in juni/juli te zijn (Bijlage 8). 

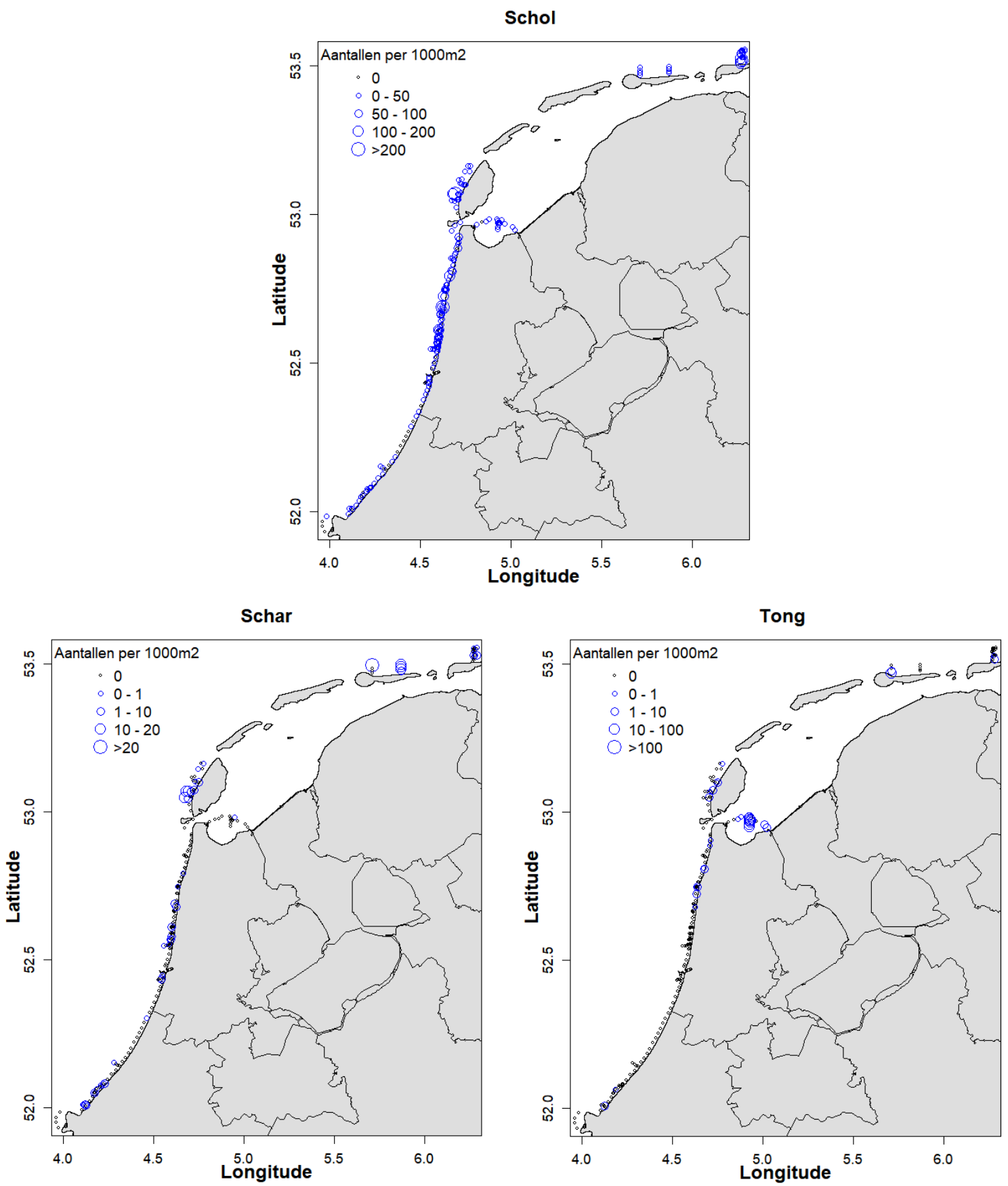

Figuur 5.22 Vangsten van de kustvak- en kustlangse bemonstering met de Luctor (2017-2020) gecombineerd. De ruimtelijke verspreiding van de vangsten van juveniele schol, schar en tong $(<9 \mathrm{~cm})$ in aantallen per $1000 \mathrm{~m}^{2}$.
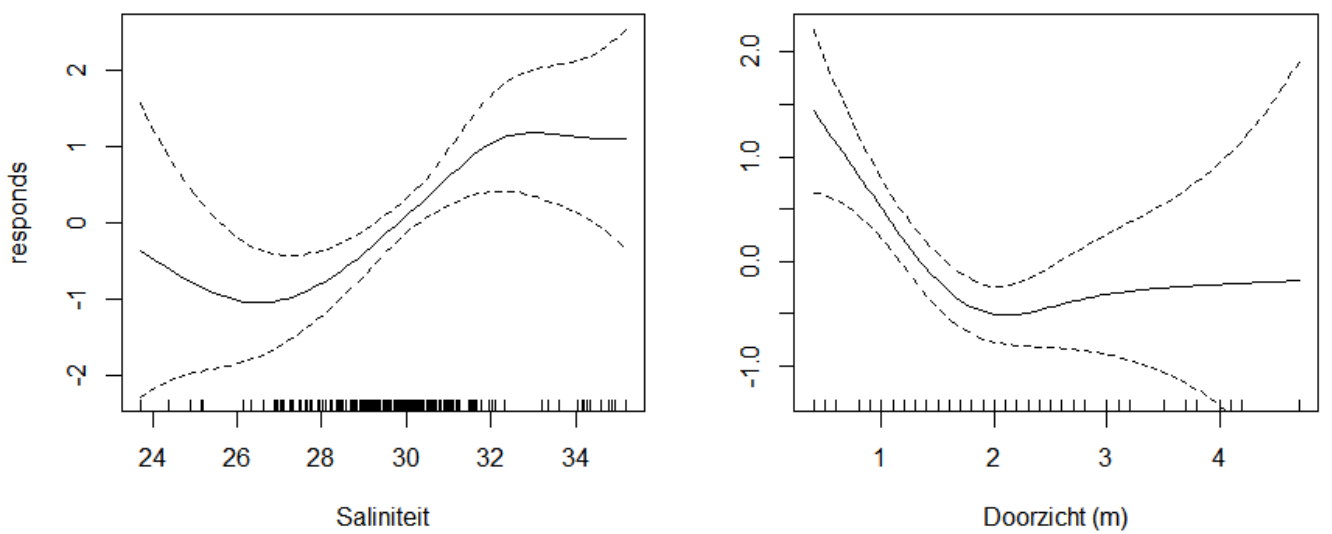

Figuur 5.23 Visuele weergave van de significante resultaten van de GAMM-analyse voor schol, gebruikmakend van de Luctorgegevens. De horizontale streepjes net boven de $x$-as zijn de warnemingen gebruikt in de analyse. 
Er wordt voor het voorkomen van juveniele schol in juni/juli in de vooroever dus geen relatie gevonden met de waterdiepte of het sediment. De gebiedsdekkende kaarten voor diepte en sediment (Figuur 5.6) hebben daardoor geen toegevoegde waarde in een voorspellend model. De variabelen saliniteit, en in meerdere mate doorzicht, zijn zeer variabel en afhankelijke van allerlei andere variabelen zoals de wind en de rivierafvoer. Desondanks zijn deze variabelen op dezelfde manier gemodelleerd als sediment, dus gebruikmakend van de gemeten waarden tijdens de veldwerkzaamheden. Vervolgens zijn deze gebruikt als inputvariabelen om de ruimtelijke verspreiding van schol te modelleren. Doordat de voorkeur voor beperkt doorzicht vooral gemeten is in de ondiepere gebieden worden de hoogste aantallen schol in deze ondiepe gebieden voorspeld. Het effect van saliniteit is te zien in de lagere aantallen in het zoetere gebied bij Zuid-Holland.
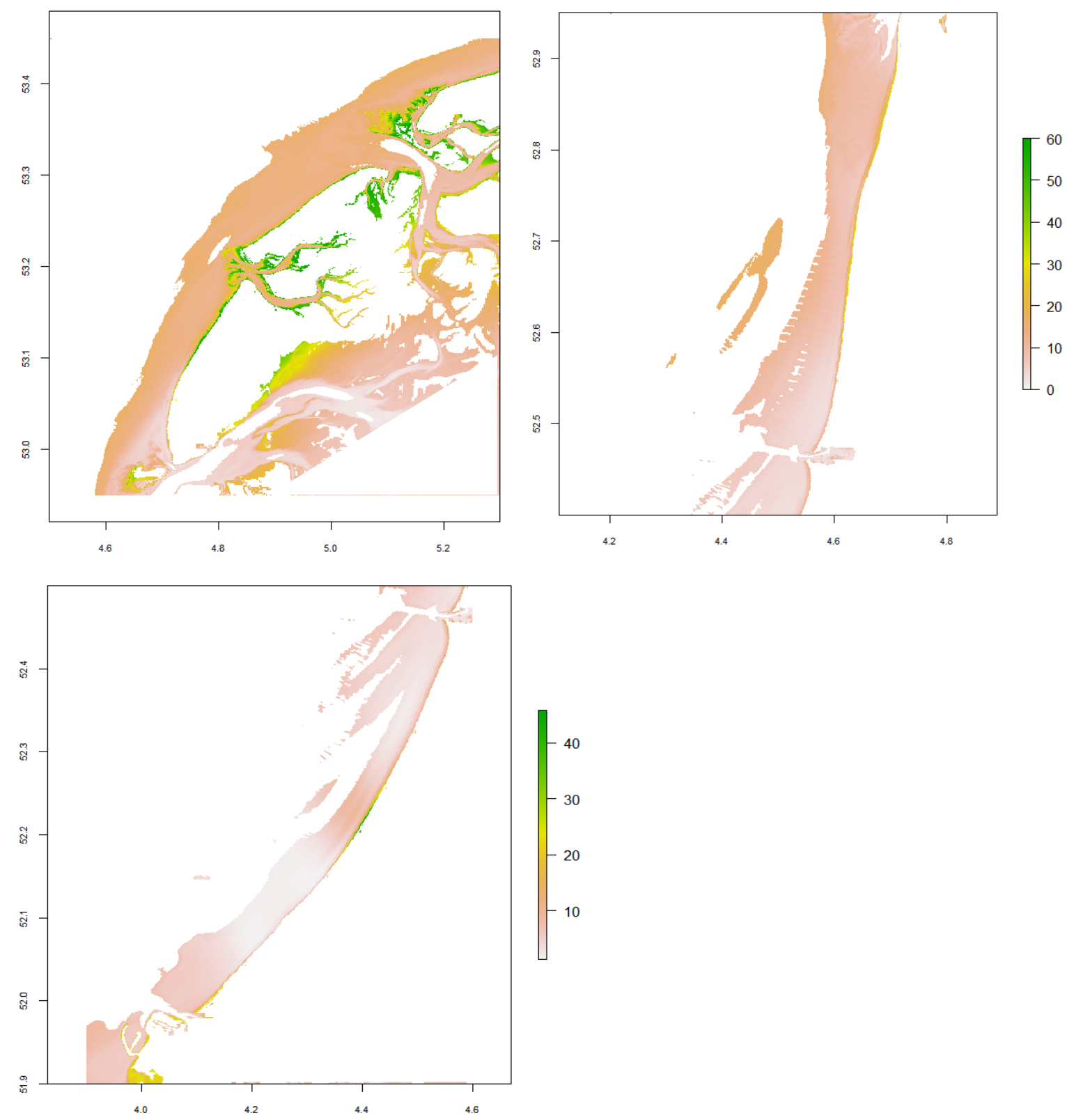

Figuur 5.24 Gemodelleerde verspreiding van schol in aantal per 1000m², gebaseerd op de GAMrelaties in Figuur 5.23.

\subsubsection{Tong}

Juveniele tong is in een beperkt aantal vistrekken vanaf de Luctor gevangen (Figuur 5.22). De hoogste dichtheden werden aangetroffen in de trekken uitgevoerd in de Waddenzee. De aanwezigheid van tong in de vangsten lijkt sterk te worden bepaald door de aanwezigheid van slib (Figuur 5.25). D50 en slib zijn gecorreleerd, de relatie met percentage slib is duidelijk sterker dan met D50. Daarnaast is er ook voor tong de indicatie dat doorzicht invloed heeft op de vangstefficiëntie. De relatie met saliniteit 
suggereert een afname tot een minimum en vervolgens weer een toename. De relatie met waterdiepte is niet significant voor tong (Bijlage 8).
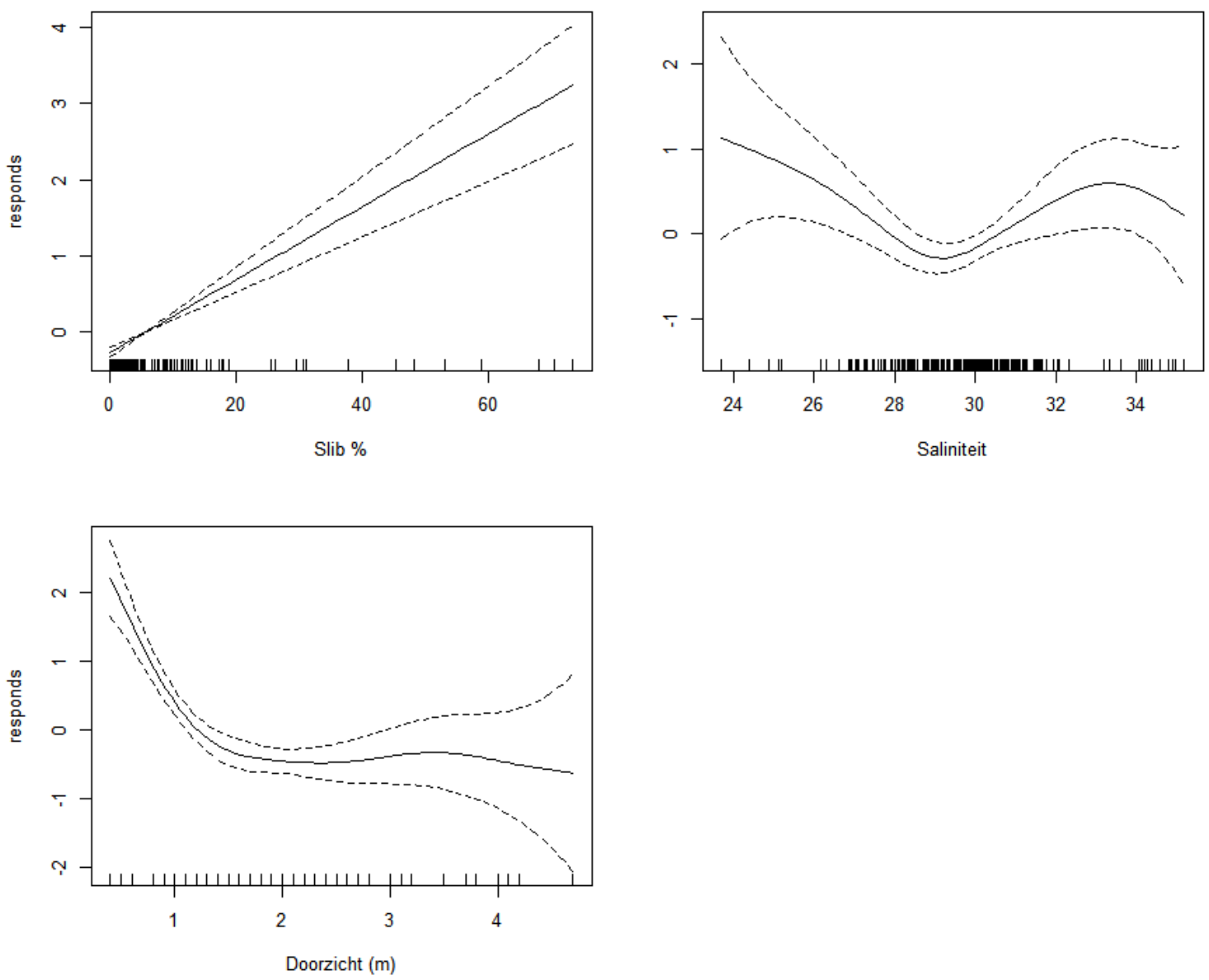

Figuur 5.25 Visuele weergave van de resultaten van de GAMM-analyse voor tong, gebruikmakend van de Luctorgegevens. De horizontale streepjes net boven de $x$-as zijn de waarnemingen gebruikt in de analyse.

De gebiedsdekkende kaart van slibgehalte weerspiegeld het beeld dat er in de vooroever nauwelijks monsters met slib zijn verzameld (Figuur 5.7). De monsters met hoge gehaltes slib liggen in de Waddenzee en daarmee worden grote delen van de Waddenzee als slibrijk gemodelleerd (Figuur 5.7). Dit zijn op basis van de GAM-relaties voor tong ook de gebieden waarvoor voorspeld wordt dat er de hoogste dichtheden juveniele tong aangetroffen wordt in juni/juli (Figuur 5.26). In de gehele vooroever wordt er nauwelijks juveniele tong voorspeld, er is alleen een licht verhoogde aanwezigheid van juveniele tong in de ondiepste gebieden zichtbaar, gebaseerd op het doorzicht dat daar als beperkt is bepaald.

\subsubsection{Tarbot en griet}

De vangsten van tarbot en griet, zelfs alle jaren gecombineerd, waren beperkt. De vangsten van griet vonden vooral plaats langs de kust van Zuid-Holland, terwijl de meerderheid van tarbot gevangen werd langs de kust van Noord-Holland (Figuur 5.27). De aantallen van tarbot en griet zijn te laag om relaties met de omgevingsvariabelen te leggen.

Om toch inzicht te krijgen in de diepte verspreiding van juveniele tarbot en griet is er gebruik gemaakt van de gecombineerde data van andere monitoringsprogramma's (Bijlage 9). Deze gegevens laten de voorkeur van juveniele tarbot en griet voor de dieptezone 0-5 m zien. 

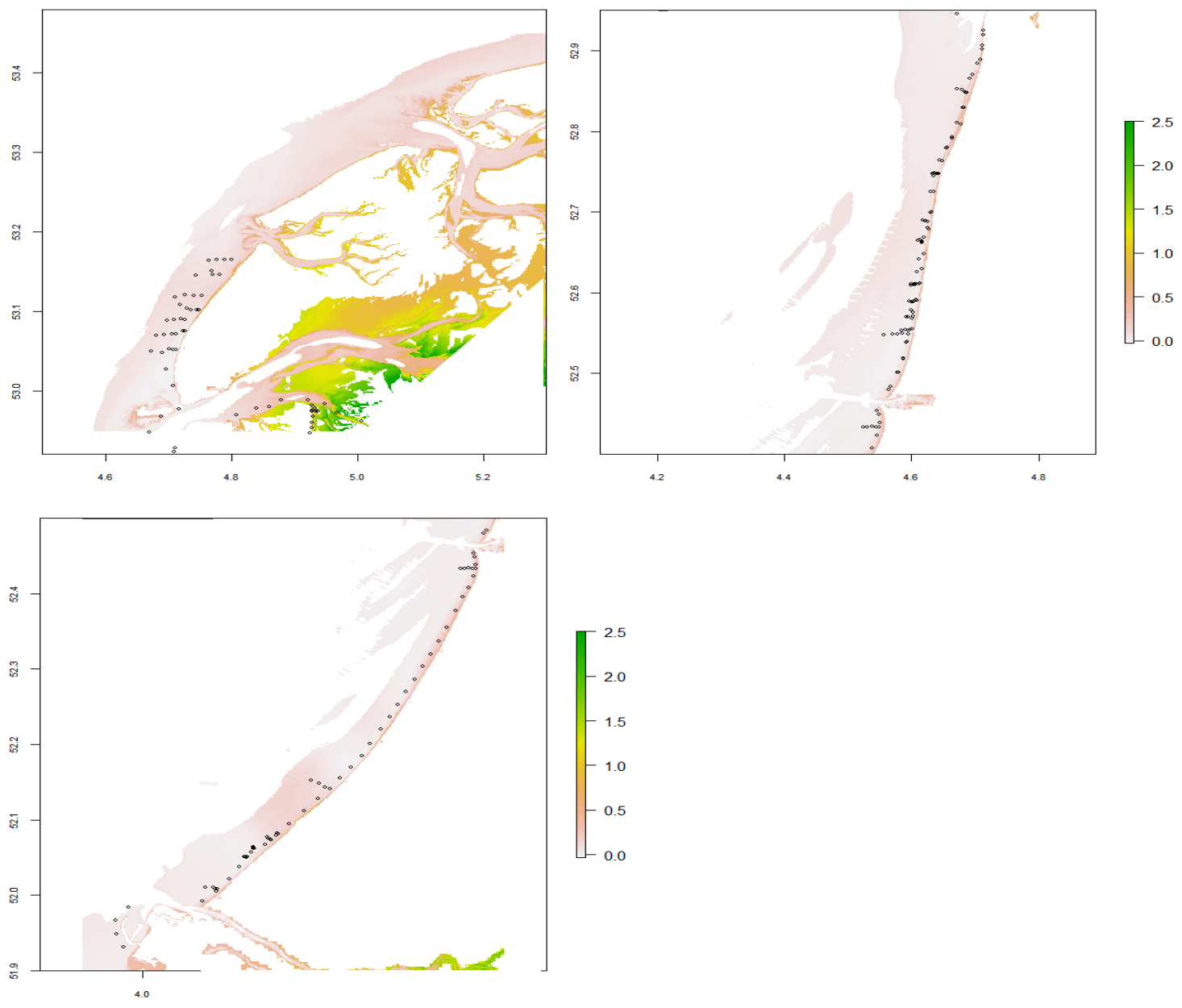

Figuur 5.26 Gemodelleerde verspreiding van tong in aantal per $1000 m^{2}$, gebaseerd op de GAMrelaties in Figuur 5.25.
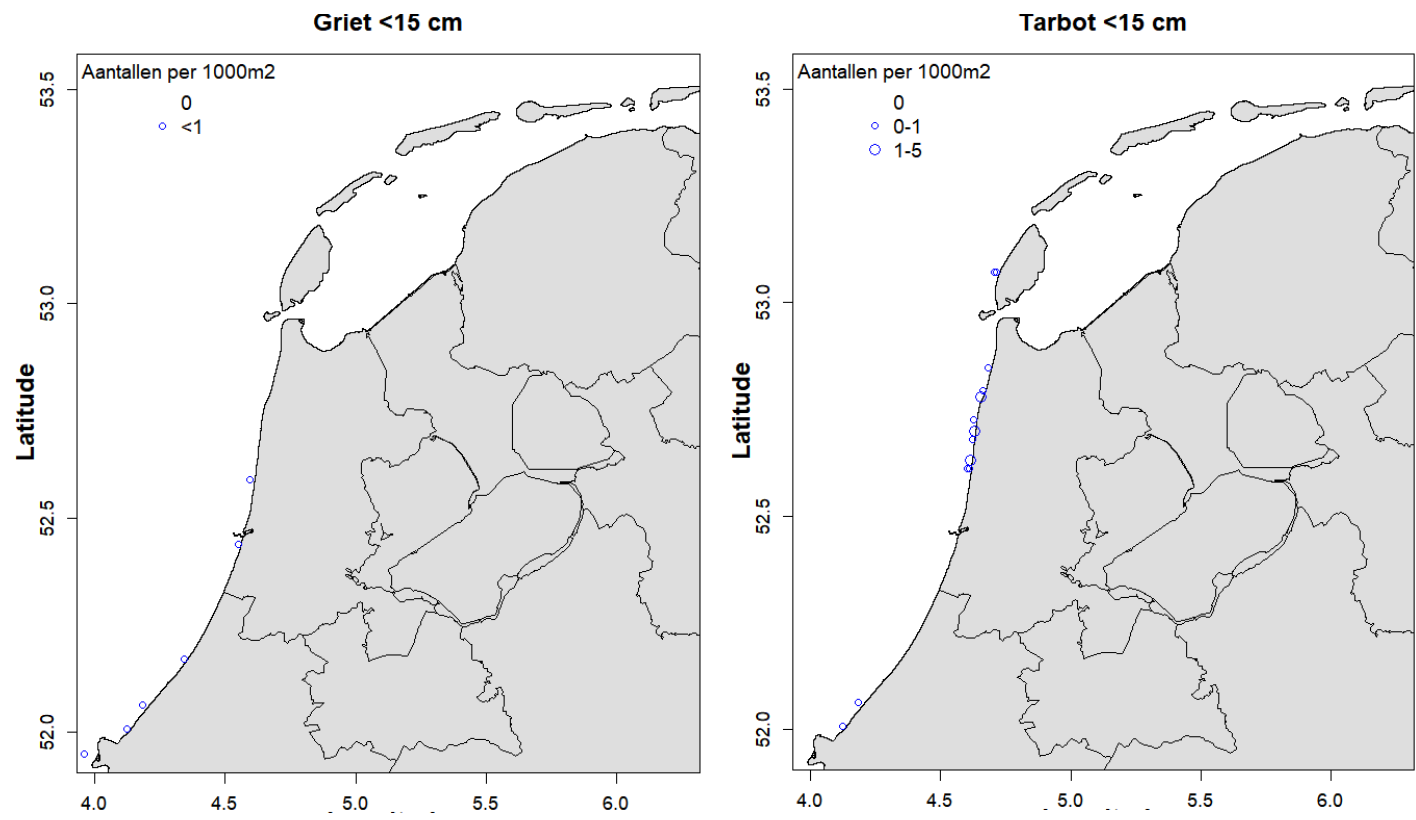

Figuur 5.27 Gegeven van de kustvak- en kustlangse bemonstering met de Luctor (2017-2020) gecombineerd. De ruimtelijke verspreiding van de vangsten van juveniele tarbot en griet $(<15$ $\mathrm{cm}$ ) in aantallen per $1000 \mathrm{~m}^{2}$. 


\subsubsection{Schar}

Schar is minder gevangen in de Luctor-bemonsteringen dan schol. Dit in tegenstelling tot de iets dieper vissende DFS en SNS waarin meer schar dan schol gevangen wordt. Schar is wel van ver in het zuiden tot aan de meest noordelijke locaties aangetroffen (Figuur 5.22), maar met duidelijke gaten, o.a. een groot deel van de Zuid-Hollandse kust en verder noordelijk richting Den Helder. Op basis van de analyses wordt duidelijk dat schar voornamelijk in de diepere trekken is gevangen, en een lichte voorkeur heeft voor het zoutere water (Figuur 5.28). De relaties met doorzicht en sediment zijn voor schar niet significant (Bijlage 8).
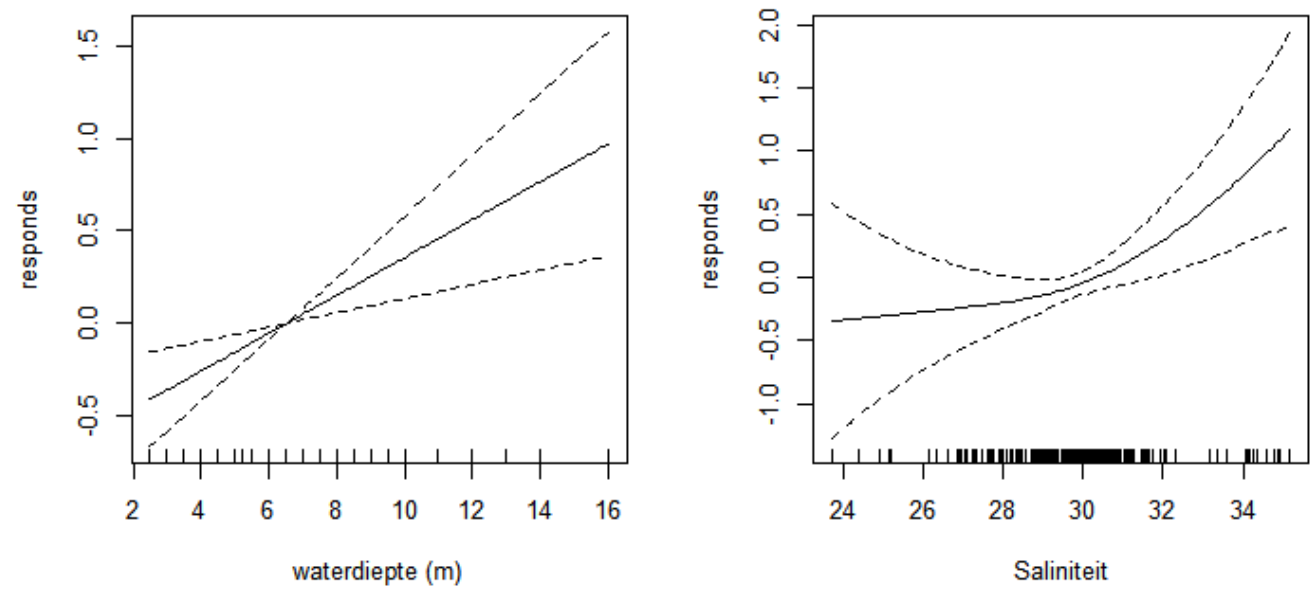

Figuur 5.28 Visuele weergave van de resultaten van de GAMM-analyse voor schar, gebruikmakend van de Luctor-gegevens.

Gebruikmakend van de relaties zou het diepere gebied ten zuidwesten van Texel, met hogere zoutgehaltes, de voorkeur hebben van juveniele schar (Figuur 5.30). Langs de rest van de kustzone is de dieptegradiënt zichtbaar, met iets meer schar vooral net buiten de bemonsterde gebieden in dieper water.
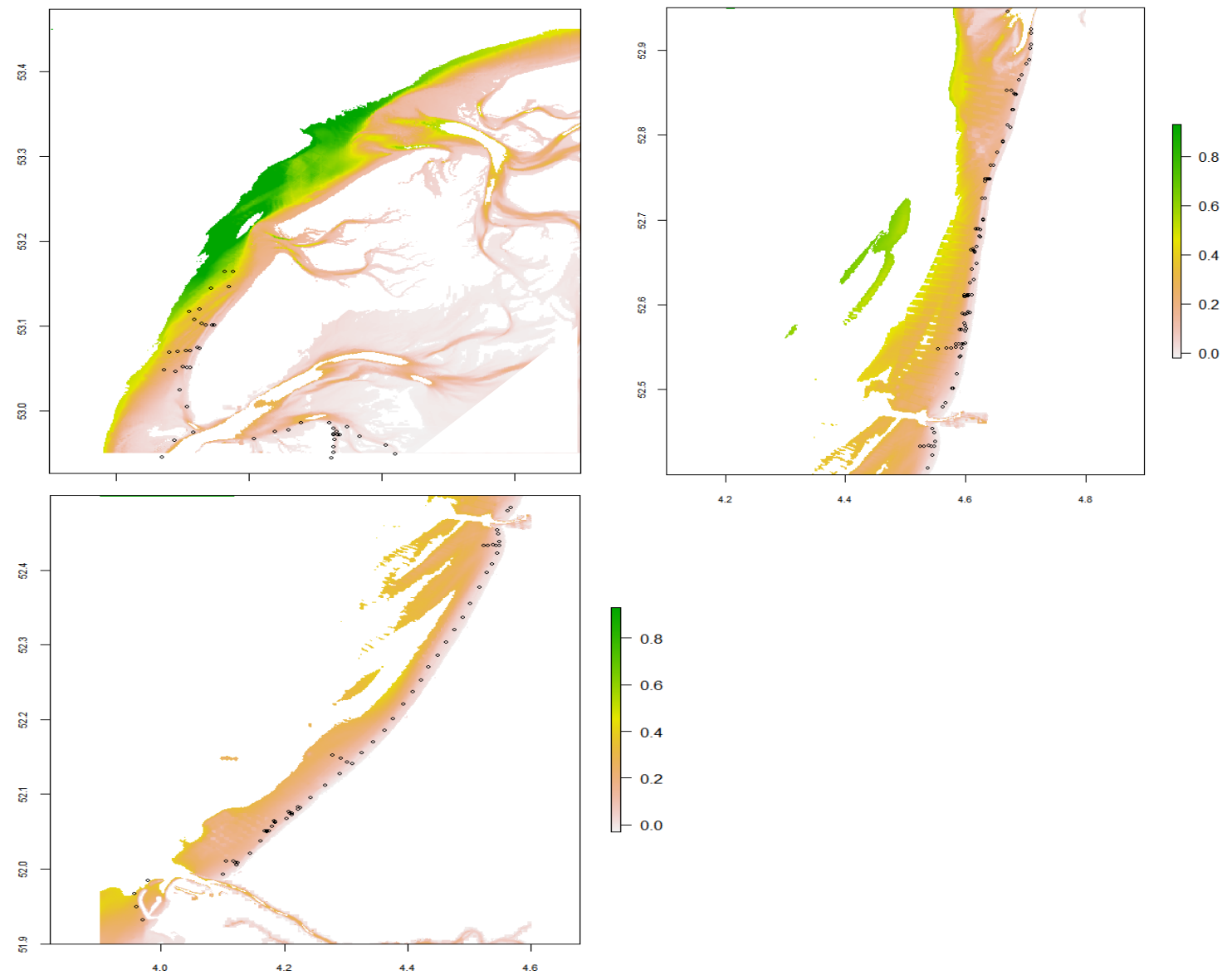

Figuur 5.29 Gemodelleerde verspreiding van schar in aantal per 1000m², gebaseerd op de GAMrelaties in Figuur 5.28. 


\subsubsection{Overige soorten}

De ruimtelijke verspreiding van andere veel voorkomende soorten (wijting, kleine zeenaald, grondel en zandspiering) in de vangst is weergegeven in Figuur 5.30. Alle vier komen langs de gehele kust voor. Wijting is nauwelijks aangetroffen in de Waddenzee. Kleine zeenaald werd echt nagenoeg in alle trekken aangetroffen, en in iets mindere mate was dit ook het geval voor grondels. Zandspiering werd niet gevangen in de trekken ter hoogte van Katwijk/Noordwijk, vergelijkbaar met schol en schar. Zandspiering werd wel aangetroffen in de trekken in het Malzwin, Waddenzee, maar niet in de trekken in het ondiepere deel van het Amsteldiep.
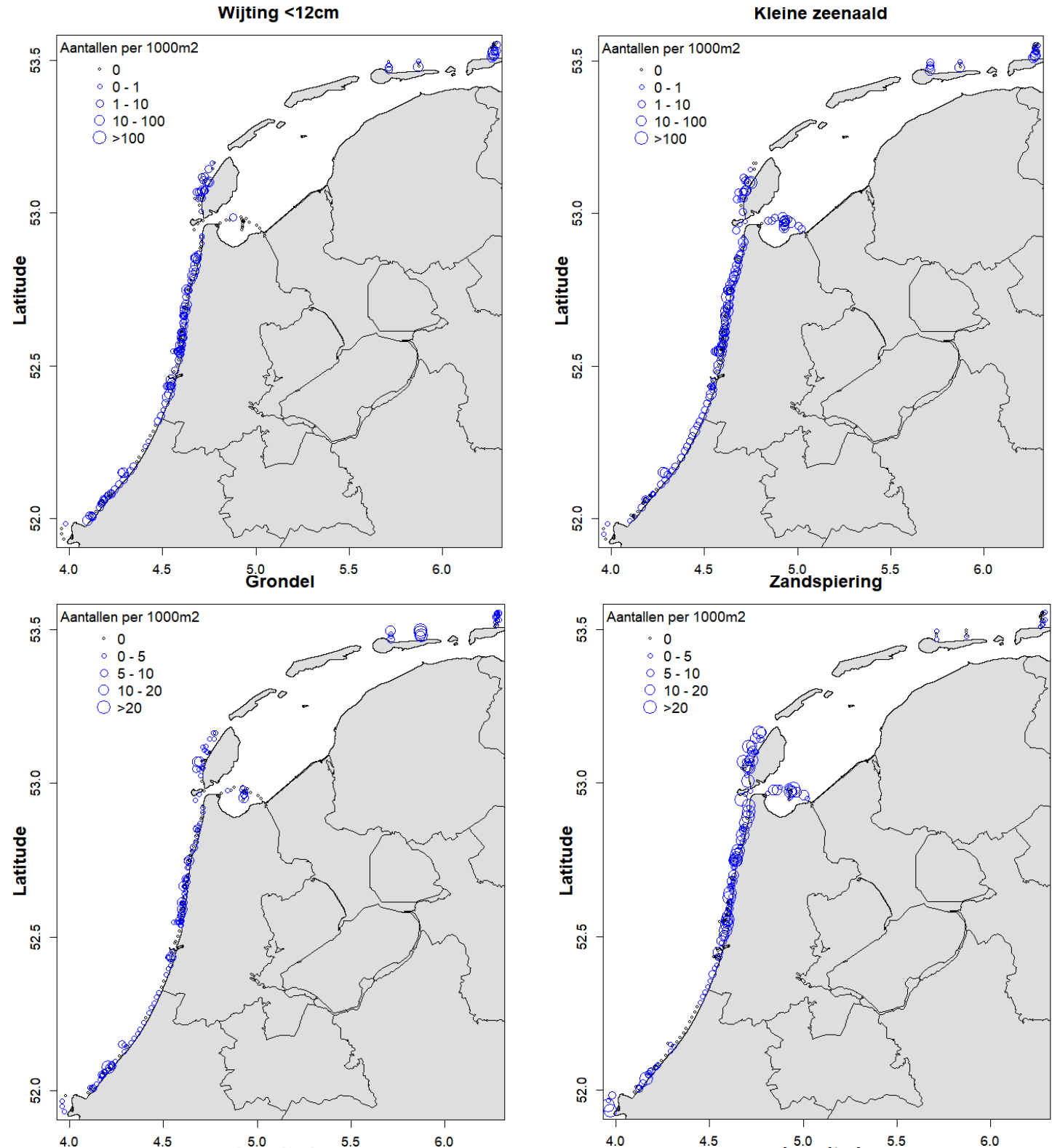

Figuur 5.30 Gegeven van de kustvak- en kustlangse bemonstering met de Luctor (2017-2020) gecombineerd. De ruimtelijke verspreiding van de vangsten van juveniele wijting ( $<12 \mathrm{~cm})$, kleine zeenaald, grondel en zandspiering in aantallen per $1000 \mathrm{~m}^{2}$.

De GAM-analyses voor wijting geven een significante relatie met waterdiepte, waarbij ze vooral in hogere aantallen werden aangetroffen in water $>4 \mathrm{~m}$. Daarnaast is er een duidelijke negatieve relatie met doorzicht en blijkt er een lichte voorkeur voor zouter water.

Kleine zeenaald laat een relatie zien met doorzicht, vergelijkbaar met de relaties voor schol en tong. Daarnaast is er een positieve relatie met saliniteit.

Voor grondels is er een positieve relatie met waterdiepte, en een negatieve relatie met de D50. Er lijkt voor grondels dus een voorkeur voor fijner sediment, terwijl ze juist grover materiaal (schelpengruis) 
nodig hebben voor het afzetten van hun eieren (Fonds, 1973). Dit grovere schelpenmateriaal wordt echter uit de monsters gezeefd voor de uitvoering van de korrelgrootte analyses.

Zandspiering laat een negatieve relatie met waterdiepte en doorzicht zien, verder is er een positieve relatie met de D50 en saliniteit.

\subsubsection{Strandbemonstering}

In 2019 is op hetzelfde moment op drie verschillende locaties, Castricum aan Zee, Katwijk aan Zee en Texel de brandingszone bemonsterd vanaf het strand. De eerste bemonstering vond plaats eind maart, waarna tot eind juni ieder twee weken werd bemonsterd. De bemonstering is door vrijwilligers vanaf juli-september voortgezet vanaf het strand bij Egmond aan Zee. In 2020, heeft WMR vanaf eind maart tot oktober een vergelijkbare bemonstering uitgevoerd van het strand bij IJmuiden, door de vrijwilligers is de bemonstering bij Egmond aan Zee voortgezet. Bij IJmuiden is er, afhankelijk van het weer, iedere 2 weken een bemonstering uitgevoerd, bij Egmond is door het jaar heen één keer per maand gevist.

Schol was de meest gevangen platvissoort in de brandingszone, waarbij op basis van de gevangen aantallen en lengteverdeling een beeld van de groei en de seizoensdynamiek in de brandingszone verkregen kon worden. Tarbot en griet werden ook regelmatig gevangen, echter waren de aantallen beperkt. Op basis van de waargenomen lengteverdeling is geprobeerd inzicht te krijgen in de aankomst periode van deze twee platvissoorten in de brandingszone. 0-groep tong is in de bemonsteringen van de brandingszone, net als in de kustvakbemonsteringen uitgevoerd in de brandingszone, niet gevangen. Wel zijn er enkele grotere oudere exemplaren gevangen.

0-groep schol werd eind april voor het eerst in de vangsten waargenomen, waarbij de lengte varieerde van $15 \mathrm{~mm}$ tot $40 \mathrm{~mm}$. Doordat in IJmuiden pas na april werd gestart met een $10 \mathrm{~mm}$ net, en op de andere locaties is gevist met $20 \mathrm{~mm}$ net, werd schol niet eerder dan eind april en ook niet kleiner dan $15 \mathrm{~mm}$ gevangen. De gevangen lengteverdeling op de verschillende locaties gedurende de strandbemonstering laat een snelle groei van 0-groep schol zien in het voorjaar (Figuur 5.31). Eind mei was de gemiddelde waargenomen lengte al boven de $40 \mathrm{~mm}$ en in de loop van juni bereikte de 0groep schol in de brandingszone een gemiddelde lengte van rond de $60 \mathrm{~mm}$. In 2019 is na juni niet meer bemonsterd op de locaties Castricum, Katwijk en Texel, terwijl in 2020 in IJmuiden na juni nog maar enkele scholletjes werden gevangen in de brandingszone (Figuur 5.31). In IJmuiden werden de piekdichtheden waargenomen in mei, waarna de dichtheden schol afnamen en na juni nauwelijks meer in de vangsten voorkwamen.
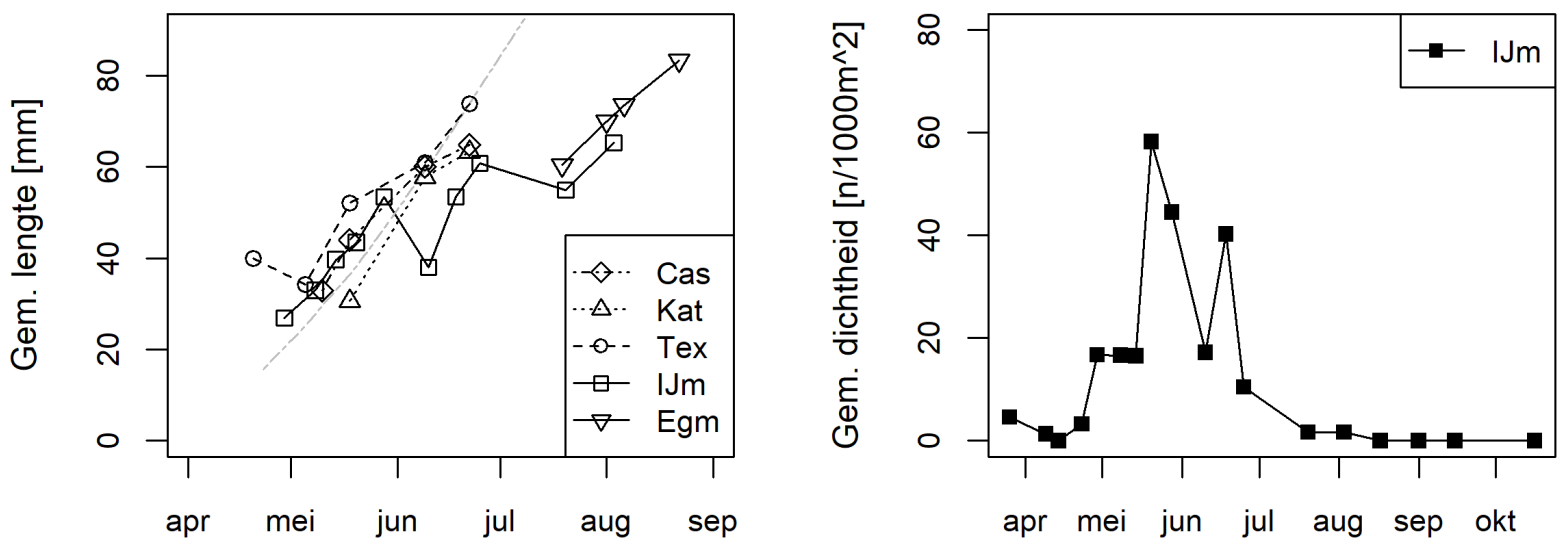

Figuur 5.31 Links: Gemiddelde lengte $(\mathrm{mm})$ van 0-groep schol aangetroffen in de vangsten van vijf strandbemonsteringen. Bemonsteringen nabij Castricum (Cas), Katwijk (Kat) en Texel zijn uitgevoerd in 2019, in IJmuiden (IJm) en Egmond (Egm) is in 2020 bemonsterd. In grijs de voorspelde groei van schol op basis van DEB. Rechts: Seizoensdynamiek in de gemiddelde dichtheid 0-groep schol in de brandingszone van IJmuiden in 2020, vangsten zijn ongecorrigeerd. Vangsten gecorrigeerd voor netefficiëntie, zie Bijlage 10. 
Tarbot werd over de gehele bemonsteringsperiode gevangen waarbij de waargenomen lengtes varieerde tussen de 25 en de $140 \mathrm{~mm}$. In april en mei werden relatief grote individuen (>50 mm) gevangen tot een lengte van $140 \mathrm{~mm}$, dit waren vermoedelijk 1-jarige tarbotten. De relatief grote individuen werden later in het jaar niet meer aangetroffen in de brandingszone, in plaats daarvan werd in de zomermaanden geregeld kleine tarbot gevangen (Figuur 5.32). De huidige gegevens laten echter geen duidelijke aankomstperiode van 0 -jarige tarbot zien, de gegevens doen eerder vermoeden dat de 0 -jarige tarbot verspreid over een ruim tijdsbestek aankomen in de kinderkamers.

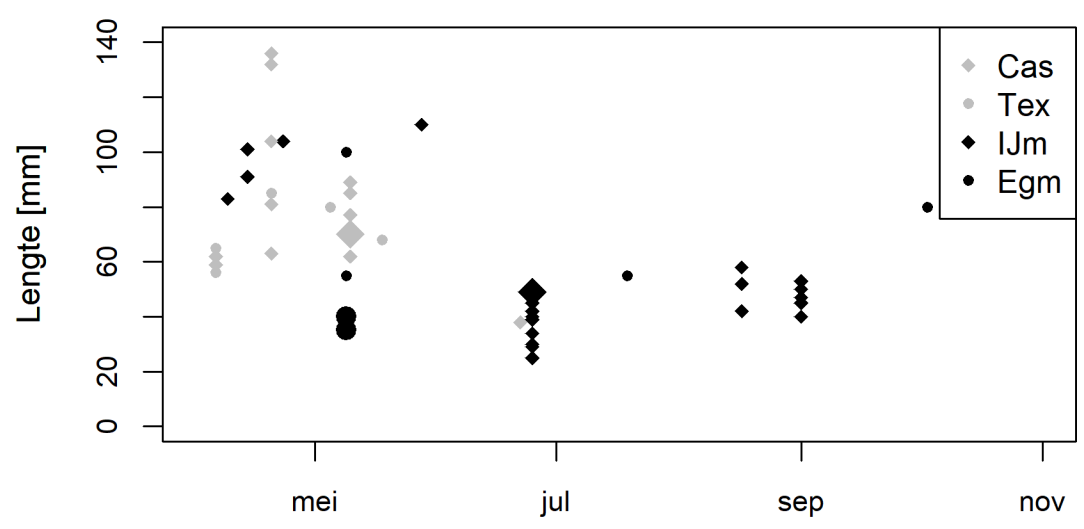

Figuur 5.32 Lengte van tarbot in de vangsten van de strandbemonsteringen in de loop van het seizoen. In grijs de vangsten in 2019 op de locaties Castricum en Texel en in zwart de vangsten in 2020 op de locaties IJmuiden en Egmond. Symboolgrootte reflecteert het aantal tarbot, waarbij de kleinste symbolen één exemplaar weergeeft en de grote symbolen twee exemplaren.

In tegenstelling tot tarbot werd griet pas eind mei voor het eerst aangetroffen in de vangsten en betrof het kleine individuen $(<50 \mathrm{~mm}$ ). Juveniele griet werd sporadisch gevangen waarbij de lengte varieerde tussen de 20 en $120 \mathrm{~mm}$ (Figuur 5.33), de kleine individuen hadden zich als vermoedelijk 0jarige griet in de brandingszone gevestigd. Ook de vangstgegevens van griet doen vermoeden dat de aankomst van griet over een ruim tijdsbestek, in de maanden juni tot september, plaatsvindt.

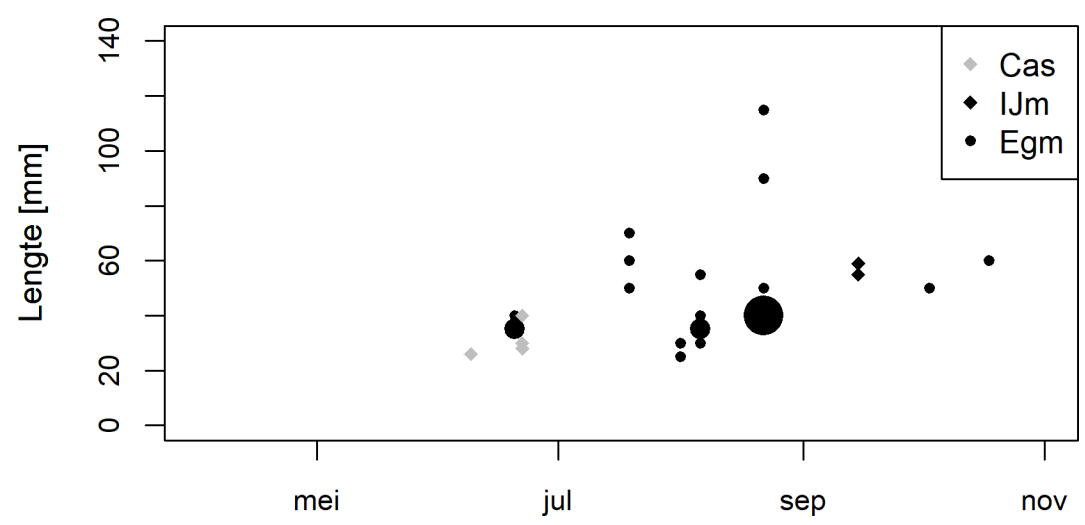

Figuur 5.33 Lengte van griet in de vangsten van de strandbemonsteringen in de loop van het seizoen. In grijs de vangsten in 2019 op de locaties Castricum en Texel en in zwart de vangsten in 2020 op de locaties IJmuiden en Egmond. Symboolgrootte reflecteert het aantal griet, waarbij de kleinste symbolen één exemplaar weergeeft, de middelste twee en het grootste symbool vier exemplaren.

Naast de vier hierboven belichte platvissoorten, is ook bot een soort die gedurende de juveniele levensfase veelvuldig wordt aangetroffen in de brandingszone. Bot werd het hele jaar door waargenomen in de vangsten, hierbij ging het in alle gevallen om juveniele exemplaren waarbij de lengte varieerde tussen de 4,5 en $15 \mathrm{~cm}$. Een andere demersale soort waarvoor de ondiepe kustzone een belangrijk opgroeigebied is en die in grote aantallen aangetroffen werd is zandspiering. Ondanks dat het gebruikte tuig hier niet geschikt voor is werd er veel juveniele zandspiering gevangen in de brandingszone. Naast zandspiering werden ook grondels aangetroffen, met name in de zomer kwamen grondels in hoge dichtheden in de geulen voor. 


\subsubsection{Dieet van schol}

Tijdens de strandbemonsteringen en de kustlangse survey in 2019 zijn er platvissen verzameld om als aanvullend studentenonderzoek het dieet te bepalen op basis van DNA uit de magen. Eerst is hiervoor een metabarcoding methode geoptimaliseerd (van Berkel, 2020). In totaal zijn tijdens deze studie 47 schollen geanalyseerd, waarvan 44 uit de juni strandbemonstering bij Castricum en drie uit de kustlangse bemonsteringen ter hoogte van Scheveningen. Van de 44 schollen varieerde de lengte tussen 5-8 cm, met drie uitschieters (een van $3 \mathrm{~cm}$ en twee van $10 \mathrm{~cm}$ ). In bijna alle vissen verschilde de soortensamenstelling tussen de maaginhoud en de resten in het darmkanaal. Daarnaast was er grote variatie in soortsamenstelling in het dieet. De meest abundante prooisoorten waren Brakwaterpok (Amphibalanus improvisus), vlokreeft (Bathyporeia sp.), kleine heremiet (Diogenes pugilator), een eenoogkreeftje (Harpacticus flexus) en een borstelworm (Scolelepis foliosa). De brakwaterpok is in zijn geheel niet aangetroffen of geregistreerd in de verschillende bemonsteringen. De vlokreeften komen algemeen voor in de vooroever en zijn aangetroffen in de helft van de benthosmonsters. De kleine heremiet werd maar in zeven benthosmonsters aangetroffen, maar werd veelvuldig aangetroffen in boomkorbemonsteringen met name tijdens de verschillende strandbemonsteringen. Het eenoogkreeftje werd niet aangetroffen in de benthosbemonsteringen. De borstelworm werd maar in een monster tot op soort gedetermineerd, Scolelepis sp. werd echter in 38 stations aangetroffen. De nauwverwante borstelworm (Scolelepis squamata) wordt veelvuldig aangetroffen in de ondiepe brandingszone (Janssen en Mulder, 2004; Holzhauer e.a., 2020).

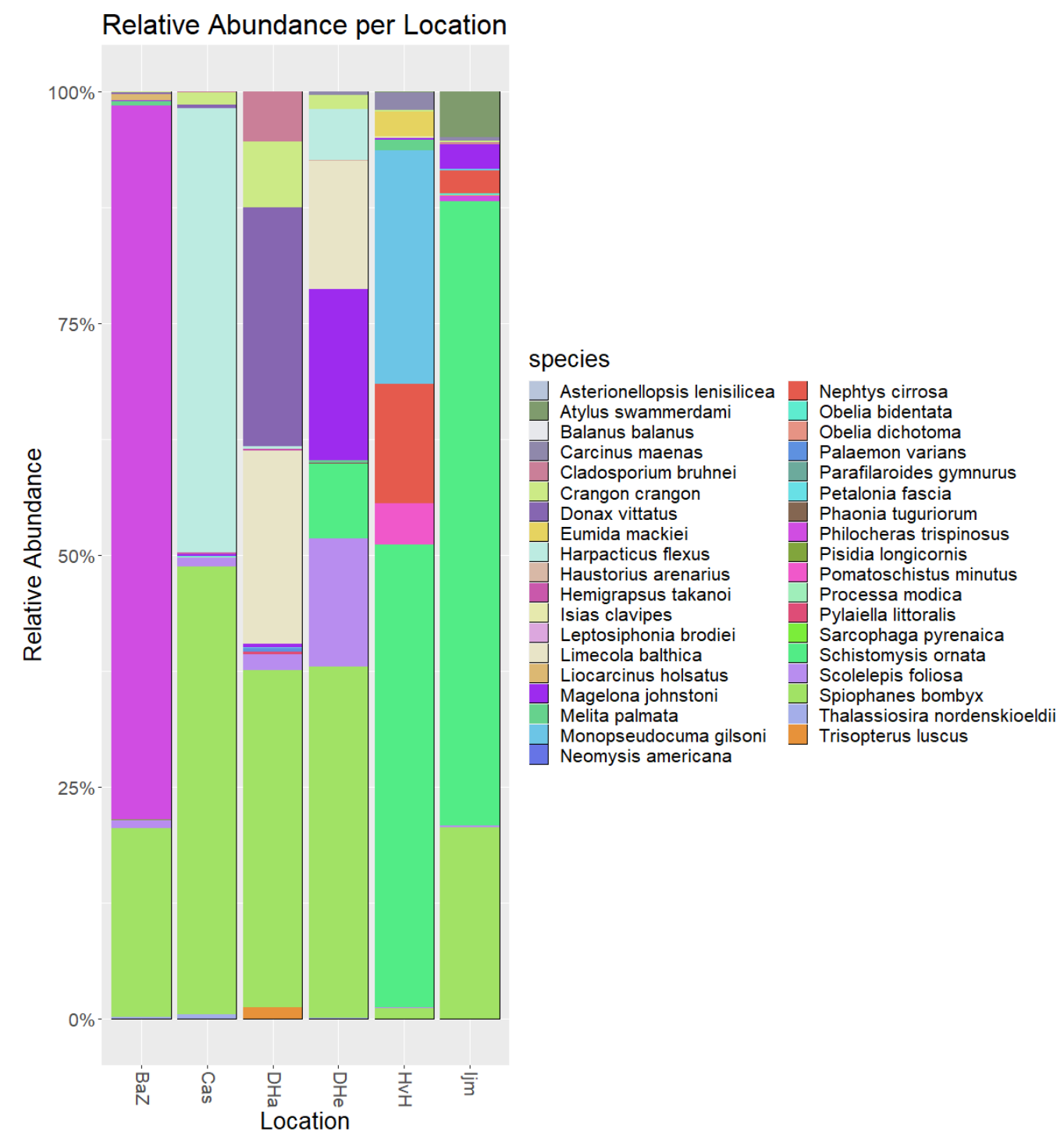

Figuur 5.34 Relatieve abundantie van soorten gevonden in het maag- en darmkanaal van schol uit de 2019 bemonsteringen per locatie. BaZ= Bergen aan Zee, Cas= Castricum, DHa= Den Haag, DHe= Den Helder, HvH= Hoek van Holland en IJm=IJmuiden (Meppelink, 2021). 
In een vervolgstudentenonderzoek is met de ontwikkelde methode het dieet bepaald van 50 schollen net als de eerdere schollen verzameld in 2019, met een lengte tussen 3-15 cm gevangen op verschillende locaties langs de Nederlandse kust, ingedeeld in zes gebieden (Meppelink, 2021). In het dieet werd DNA aangetroffen van 41 soorten, waaronder dat van mensen en van schol. Het DNA van mensen is waarschijnlijk afkomstig van vervuiling tijdens het verwerken van de monsters. Het DNA van schol is hoogst waarschijnlijk eigen DNA wat niet volledig geblokkeerd wordt door de gebruikte blockingprimer, echter kannibalisme kan niet worden uitgesloten.

De meest abundante soorten in het dieet waren aasgarnaal (Schistomysis ornata), de noordelijke zandkokerworm (Spiophanes bombyx), de zeekomma (Monopseudocuma gilsoni), het eenoogkreeftje (Harpacticus flexus) en de driepuntsgarnaal (Philocheras trispinosus). De zandkokerworm werd in het dieet aangetroffen van vis afkomstig van alle locaties (Figuur 5.34). Terwijl de driepuntsgarnaal nagenoeg alleen werd aangetroffen in het dieet bij Bergen aan Zee. De zandkokerworm werd aangetroffen in iets meer dan de helft van de benthosmonsters. De aasgarnaal en de driepuntsgarnaal werden in de strandbemonsteringen geregeld in lage aantallen aangetroffen tussen de gewone garnaal. Voor beide soorten geldt dat de gebruikte maaswijdte in de boomkor te groot is om ze representatief te bemonsteren. Zeekomma werd in 16 benthosmonsters aangetroffen, voornamelijk monsters uit het kustvak Schiermonnikoog. Deze meest abundante soorten in het dieet werden gevolgd door andere veel in de vooroever voorkomende soorten als Bathyporeia sp., Nepthys cirrosa, Magelona Johnstoni (van Hal e.a., 2021). Ook de schelpdieren nonnetje (Limecola balthica) en zaagje (Donax vittatus) werden in het dieet aangetroffen. Het nonnetje voornamelijk in het dieet van de grootste schollen $(>12 \mathrm{~cm}$ ).

Enigszins verrassend is de relatief beperkte aanwezigheid van gewone garnaal in de dieetmonsters. De gewone garnaal domineert nagenoeg alle vangsten met de boomkor. Enkele eerdere dieetstudies lieten een dominantie van gewone garnaal zien in het dieet op basis van DNA (Heindler e.a., 2019) en visuele identificatie (Beyst e.a., 1999). Terwijl andere studies een beperktere dominantie van gewone garnaal lieten zien (De Vlas, 1979; Amara e.a., 2001). In de bemonsteringen in de Voordelta (20052012) werd het dieet in het voorjaar van 2007 gedomineerd door Crustacea en Cumacea, maar in de andere jaren werd het dieet van juveniele schol gedomineerd door Polychaeta en voor de iets grotere schol in sommige jaren door Ensis (Tulp e.a., 2016a). Er is dus grote variatie in de dieetsamenstelling en dit verschilt tussen gebieden en jaren. Een mogelijk verklaring voor het ontbreken van gewone garnaal in het dieet in de vooroever is dat de kleinere aas- en driepuntsgarnalen makkelijkere prooien zijn dan die iets grotere gewone garnaal.

\subsubsection{DFS tijdserie}

Om eventuele veranderingen in de ruimtelijke verspreiding van juveniele platvis (schol en tong) in de kustzone in kaart te brengen zijn de gegevens van de Demersal Fish Survey (DFS) gebruikt. De DFS is opgezet om juveniele (plat)vis te vangen en is sinds 1970 jaarlijks in het najaar uitgevoerd waarbij de kustzone wordt bemonsterd op verschillende waterdieptes. Zodoende kon een tijdserie van de ruimtelijke verspreiding van juveniele platvis in de kustzone gemaakt worden. Gekozen is om gebruik te maken van twee diepte categorieën van waterdieptes tot en met $10 \mathrm{~m}$ diep en waterdieptes van 10 $\mathrm{m}$ tot $25 \mathrm{~m}$. Een maximum van $25 \mathrm{~m}$ diepte is gekozen omdat enkel in de jaren voor 1990 dieper dan 25 meter is gevist. Op basis van de lengtefrequenties per jaar zijn 0-groep schol (maximale lengte 14 - $18 \mathrm{~cm}$, per jaar verschillend) en tong (maximale lengte $11-18 \mathrm{~cm}$, per jaar verschillend) geselecteerd voor de verdere opwerking. De aantallen platvis zijn per dieptecategorie en per jaar opgewerkt naar gemiddelde dichtheden 0-groep schol en tong (aantal per hectare).

De dichtheden schol in de kustzone laten een grote jaar tot jaar variatie zien, deels natuurlijke variatie maar ook doordat niet ieder jaar eenzelfde aantal stations is bemonsterd. Ondanks de jaarlijkse variatie waren de dichtheden juveniele schol in de eerste twee decennia waarin de DFS is uitgevoerd structureel hoger in water $<10 \mathrm{~m}$ diep dan in de diepere kustwateren (Figuur 5.35). In deze eerste twee decennia zijn echter structureel meer stations bemonsterd in diepere wateren dan in water $<10$ $\mathrm{m}$ diep. In de loop van de negentiger jaren wordt het verschil in dichtheid steeds minder, ook het aantal bemonsterde stations is vanaf 1990 vrijwel gelijk voor beide diepteklassen (op enkele jaren na). In de jaren die volgden tot aan de meest recent uitgevoerde DFS (2020) was de dichtheid juveniele schol over de gehele dieptegradiënt nagenoeg gelijk. De Noordzeekustzone heeft nog steeds 
een belangrijke functie als kinderkamer voor juveniele schol, alleen de manier waarop schol gebruikt maakt van de kustzone lijkt wat veranderd te zijn. Daar waar schol in de eerste decennia van de DFS in hogere dichtheden werd aangetroffen in de ondiepe kustwateren, komt schol nu in dezelfde mate verspreid over de gehele kustzone voor.

\section{0-Groep Schol}

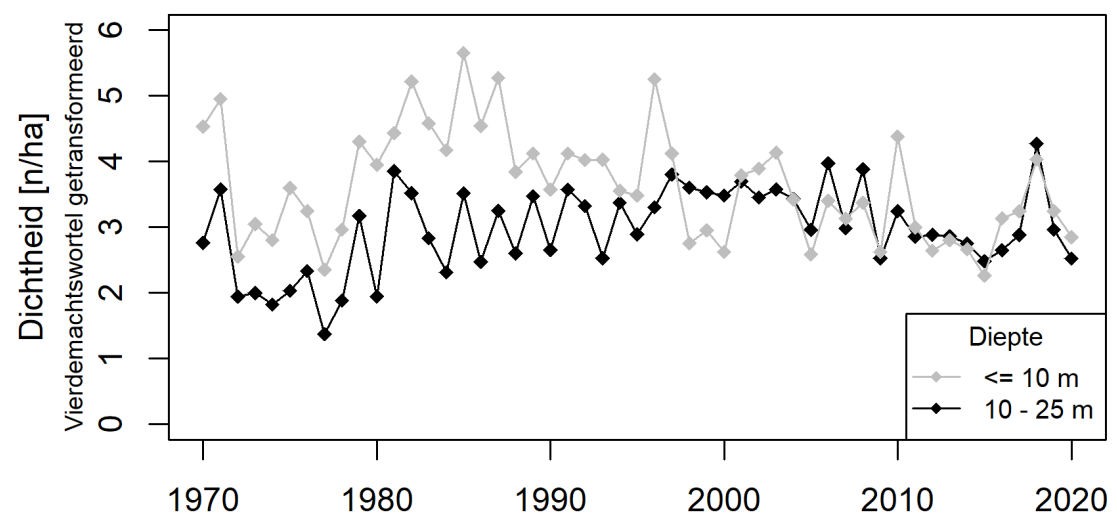

Figuur 5.35 Tijdserie van de gemiddelde dichtheid (vierdemachtswortel getransformeerd (aantal per hectare)) 0-groep schol in de Noordzeekustzone in het najaar tijdens de DFS voor waterdieptes tot $10 \mathrm{~m}$ en dieper dan $10 \mathrm{~m}$.

Tong laat ook grote jaar tot jaar schommelingen in dichtheid in de kustzone zien. Net als voor schol waren de dichtheden juveniele tong structureel hoger in water ondieper dan $10 \mathrm{~m}$ dan in dieper water in de eerste twee decennia waarin de DFS is uitgevoerd (Figuur 5.36). Ook voor tong werd dit verschil steeds minder, al in de jaren negentig van de vorige eeuw waren de dichtheden juveniele tong in de ondiepe kustzone vrijwel gelijk aan die van het diepere kustwater (>10 m). Tot de meest recent uitgevoerde DFS (2020) is dit niet meer veranderd en zijn de dichtheden juveniele tong over de gehele dieptegradiënt nagenoeg gelijk. Juveniele tong lijkt in dezelfde mate verspreid over de gehele kustzone voor te komen. De tijdserie impliceert dat de totale gemiddelde dichtheid in de Noordzeekustzone is afgenomen, en daarmee is de functie van het ondiepste deel van de Noordzeekustzone als kinderkamer voor tong afgenomen.

\section{0-Groep Tong}

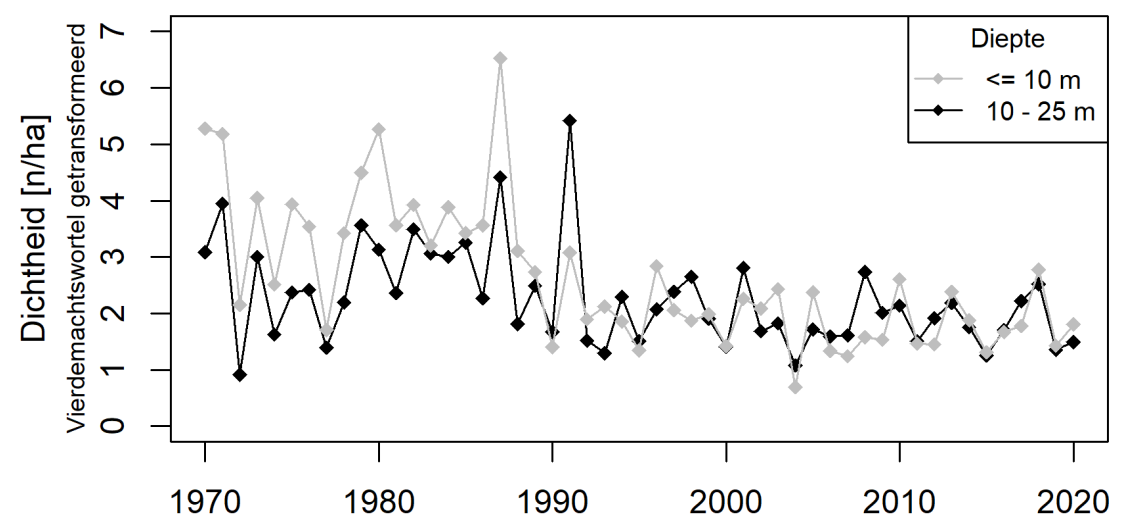

Figuur 5.36 Tijdserie van de gemiddelde dichtheid (vierdemachtswortel getransformeerd (aantal per hectare)) 0-groep tong in de Noordzeekustzone in het najaar tijdens de DFS voor waterdieptes tot $10 \mathrm{~m}$ en dieper dan $10 \mathrm{~m}$. 


\subsection{Pelagische vis}

De akoestische bemonsteringen in 2017 en 2018 lieten duidelijk zien dat pelagische vis sterk gefragmenteerd, in scholen, aanwezig was in de vooroever langs de Nederlandse kust (Couperus e.a., 2020). Hierdoor waren er grote verschillen tussen locaties en bemonsteringsdagen. Pelagisch vissen was vanaf de Luctor technisch niet mogelijk waardoor de echo's niet toegekend konden worden aan soorten. Desondanks is op basis van de vangsten met een $3 \mathrm{~m}$ boomkor, een demersaal vistuig, toch een schatting gemaakt van de dichtheid pelagische vis in de vooroever. In vrijwel de meeste vistrekken kwamen haring en sprot (Clupeidae) voor, dat maakt het aannemelijk dat de waargenomen scholen vis op de echo's ook Clupeidae waren. De geschatte gemiddelde dichtheid pelagische vis is daarom gebaseerd op Clupeidae, en leverde een dichtheid van $98 \mathrm{~kg}$ pelagische vis per hectare op. Een schatting in dezelfde orde van grootte als in een vergelijkbare studie uitgevoerd in het Marsdiep in mei 2010 en 2011 (Couperus e.a., 2016). Echter, naast haring en sprot werd zandspiering in bijna de helft van de boomkortrekken aangetroffen. Indien de waargenomen scholen vis geheel uit zandspiering zou bestaan, dan zou de geschatte dichtheid pelagische vis vele malen hoger uitvallen vanwege het verschil in akoestische reflectie tussen zandspiering en Clupeidae.

\subsubsection{Strandbemonstering}

Tijdens de kustvakbemonsteringen in 2017 en 2018 is er gebruik gemaakt van een zegen (13 monsters) om een beeld te krijgen van de aanwezigheid van pelagische vis in de brandingszone. De meest voorkomende vissoort in deze vangsten was juveniele haring (370), die werd aangetroffen in alle kustvakken. Daarnaast is er zandspiering (102) gevangen, die in een beperkter aantal trekken werd aangetroffen. Daarnaast werden nog twee sprot en een zeebaars gevangen en verder kwallen en garnalen.

In 2019, bij Katwijk, Castricum en Texel, werd gebruik gemaakt van een uitscherende kornet en een boomkor. Hierbij werden ook vooral haringachtigen gevangen (Bijlage 1). Een deel kon worden gedetermineerd als haring, maar een groot deel bevond zich nog in het larvale stadium en kon in het veld niet op soort worden gebracht. Op basis van de aantallen is duidelijk dat grote aantallen larven in brandingszone en vooroever voorkomen. Ten opzichte van de aantallen in de volledige zuidelijk Noordzee zijn deze aantallen waarschijnlijk beperkt, en het is onduidelijk of de brandingszone een geprefereerde habitat is of dat ze tegen hun wens de brandingszone in stromen. Naast de Clupeidae werden maar een beperkt aantal andere pelagische soorten aangetroffen, waaronder glasgrondel, zeebaars, harder, en koornaarvis (Atherina presbyter).

Gedurende de strandbemonstering in 2020 werd relatief veel pelagische vis gevangen ondanks het gebruik van demersale vistuigen. Doordat in zeer ondiep water werd gevist $(<1 \mathrm{~m})$, werd daarmee een aanzienlijk deel van de waterkolom bemonsterd. In de getijdengeulen werd in de meeste gevallen de gehele waterkolom bemonsterd omdat de waterdiepte vlak voor aanvang van laagwater veelal minder dan $50 \mathrm{~cm}$ betrof. De pelagische vissen die zich in de brandingszone ophielden werden daarmee in aanzienlijke aantallen gevangen. Naast Clupeidae, die in de grootste aantallen voorkwamen, zijn o.a. ook ansjovis (Engraulis encrasicolus), goudharder (Liza aurata), koornaarvis, pelser (Sardina pilchardus) en zeebaars aangetroffen in de vangsten in de brandingszone. Van deze soorten werden goudharder en zeebaars het meest aangetroffen in de vangsten, met name in de getijdengeulen. Goudharder werd vrijwel uitsluitend gevangen in de getijdengeulen waarbij de lengtes die werden aangetroffen varieerde van kleiner dan $3 \mathrm{~cm}$ tot groter dan $10 \mathrm{~cm}$. De vangsten van juveniele goudharder doen sterk vermoeden dat de getijdengeulen fungeren als kinderkamer voor deze soort. Het water in de geulen warmt sneller op in vergelijking met de aangrenzende brandingszone en geeft daarnaast beschutting tegen predatoren. Ook zeebaars maakt gebruik van de kinderkamerfunctie van de getijdengeulen. Juveniele zeebaars met een lengte kleiner dan $3 \mathrm{~cm}$ werd hier in grote aantallen aangetroffen in augustus. Aan het eind van oktober hadden de meeste 0 -jarige zeebaarzen al een lengte van boven de $6 \mathrm{~cm}$, waarbij enkele individuen van rond de $10 \mathrm{~cm}$ werden aangetroffen. De overige pelagische soorten zoals ansjovis, koornaarvis en pelser kwamen geregeld voor in de vangsten in de brandingszone, echter in geringe aantallen. Kortom, de ondiepe kustzone fungeert niet uitsluitend als kinderkamer voor platvis maar ook pelagische vissen maken gebruik van de ondiepe kustzone als kinderkamer. 


\section{$6 \quad$ Belang van de vooroever als kinderkamer}

De aanwezigheid van vis of een bepaald levensstadium in een gebied maakt niet direct dat een gebied van groot belang is voor de populatie. Zelfs als een gebied cruciale omstandigheden omvat voor de groei en overleving van een levensstadium, is het niet vanzelfsprekend dat een specifiek gebied een substantiële bijdrage levert aan de populatieomvang. Om het belang van een gebied te bepalen is het relevant om een indicatie te hebben hoe uniek een gebied is en inzicht te hebben in de groei en mortaliteit om de absolute bijdrage aan de populatie in te kunnen schatten.

In het geval van schol wordt de Nederlandse kustzone aangeduid als cruciale kinderkamer, meestal is deze uitspraak gebaseerd op gegevens uit de Waddenzee en de Schelde estuaria, aangevuld met de gegevens van de diepere kustzone $(5-15 \mathrm{~m})$ gebaseerd op de reguliere surveys. Historische schattingen kwamen er op uit dat ongeveer $80 \%$ van alle jonge schol in de Nederlandse wateren zich in de Waddenzee bevond en dat ongeveer $20 \%$ zich in de Nederlandse kustwateren bevond (Zijlstra, 1972). En dat voor de volledige Noordzeepopulatie ongeveer 60\% uit de Waddenzee, inclusief het Duitse en Deense deel, afkomstig is (Zijlstra, 1972; Bergman e.a., 1988). Hierbij werd wel opgemerkt dat er grote onnauwkeurigheid in deze data zat, met name vanwege de grote variatie in aantal schol per trek en omdat er dicht bij de kust en op ondiepe platen niet gevist kon worden. Als vervolg op die studie is de DFS ontstaan en op basis daarvan werd voor de periode 1978-1982 het belang van de zuidoostelijk kinderkamers voor de Noordzeepopulatie van schol bevestigd (van Beek e.a., 1989). Volgens deze studie, was binnen de zuidoostelijke kinderkamer het belang van de Belgische kust en Schelde estuaria tezamen $<2 \%$. De bijdrage van de Nederlandse kust was $\sim 13 \%$, en die van de Nederlandse Waddenzee $\sim 48 \%$. De overige $~ 36 \%$ was afkomstig uit de Duitse Bocht. De zuidoostelijke kinderkamers waren daarmee veruit het belangrijkst voor de Noordzeepopulatie, maar ook de kinderkamers aan de Engelse oostkust ( $9 \%$ ) en die ten noorden van Jutland (onbekend \%) dragen bij aan de Noordzeepopulatie van schol (van Beek e.a., 1989).

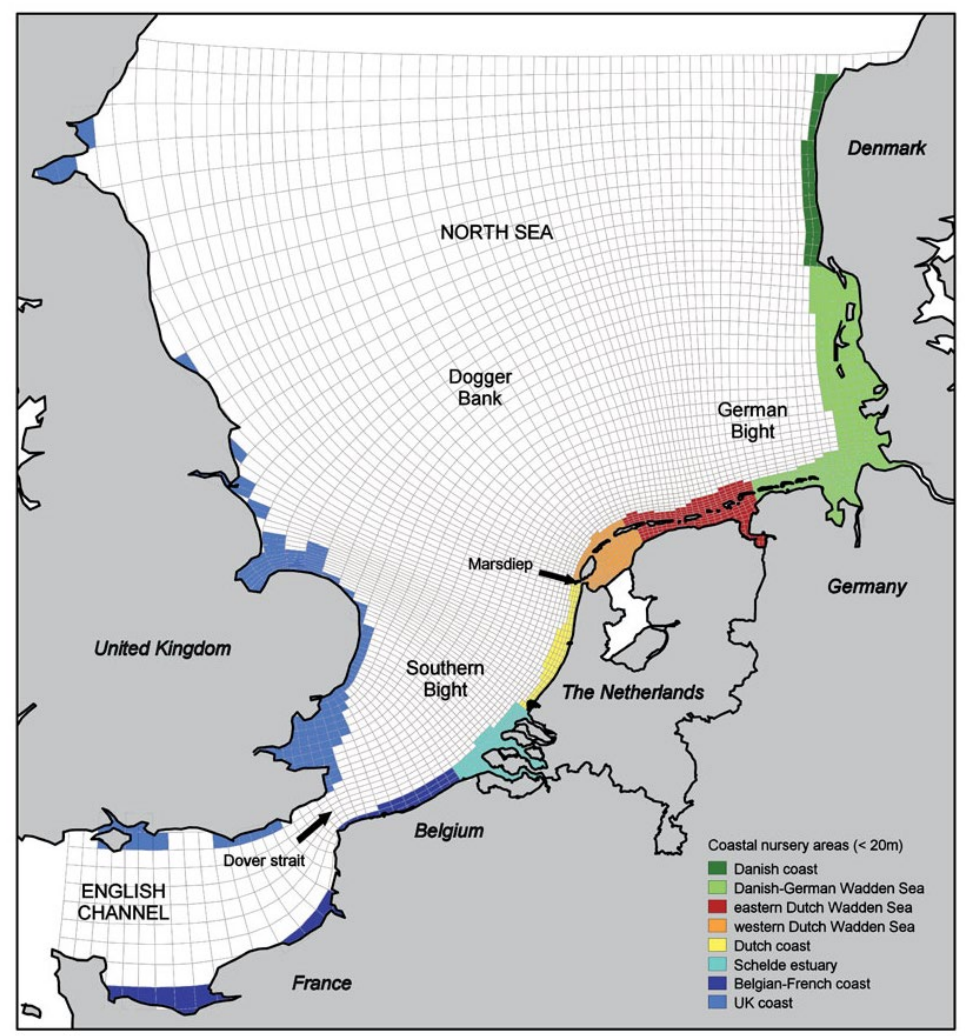

Figuur 6.1 De potentiële kinderkamergebieden voor schol (Bolle e.a., 2009). 
Een ruimtelijke weergave van de potentiële kinderkamers voor schol (Figuur 6.1), maakt zichtbaar dat het oppervlakte beschikbaar als kinderkamer langs de Nederlandse zandstranden aan de Hollandse kust en de Noordzeezijde van de Waddeneilanden beperkt is ten opzichte van de oppervlakte van de volledige Waddenzee. Het belang van de verschillende gebieden is dus mogelijk een directe afspiegeling van het verschil in oppervlakte.

Verschillende studies suggereren echter dat de habitatkwaliteit in de Waddenzee beter was/is dan die in de kustzone. Hierbij zou een hogere voedselbeschikbaarheid en met name lagere predatiedruk in het voordeel van de Waddenzee zijn (Bergman e.a., 1988; van der Veer e.a., 1990). Voedsel lijkt echter in de meeste gebieden niet limiterend te zijn, tenminste tot aan het einde van de zomer (Bergman e.a., 1988; van der Veer e.a., 1990; Teal e.a., 2008; Ciotti e.a., 2013a). Op kleinere schaal zorgde de voedselsamenstelling in verschillende gebieden van de Waddenzee wel voor verschillen in groei (Van der Veer en Witte, 1993). De grootste druk op nieuwe aanwas van schol komt echter van predatie door garnalen (Crangon crangon), deze foerageren op juveniele schol met een lengte tot 3 cm (van der Veer en Bergman, 1987; Van der Veer en Witte, 1993; Gibson e.a., 1995), en predatie van grotere vis (Ellis en Gibson, 1995). Met name die laatste zijn in de Waddenzee beperkt aanwezig en zouden voor een lagere predatiedruk in de Waddenzee kunnen leiden (Bergman e.a., 1988). Een vroegere studie waarbij in de vooroever bij Callantsoog en op twee locaties in de Waddenzee werd bemonsterd suggereerde een hogere groeisnelheid in de kustzone ten opzichte van de Waddenzee (de Vries, 1974). Een latere studie waarbij in de vooroever bij Texel op verschillende dieptes werd bemonsterd vond ook dat hier voedselaanbod en competitie niet beperkend waren en dat voor de geldende temperaturen de maximale groeisnelheid werd behaald (Mengedoht, 1995). Ook de mortaliteit van schol was hier vergelijkbaar met de gevonden mortaliteit op het Balgzand. Op basis van die gegevens was de conclusie dat de vooroever een vergelijkbare habitatkwaliteit heeft als de getijdenplaten in de Waddenzee (Mengedoht, 1995). Meer recent, in de aangelegde lagune van de Zandmotor in de vooroever werden niet de maximale groeisnelheden behaald, voor groei leek dit geen optimale habitat. Terwijl in de referentiegebieden in de vooroever groeisnelheden werden behaald die dicht tegen de maximale groeisnelheden aan lagen (Meeuwissen, 2014).

Binnen Natuurlijk Veilig is met name de visdichtheid in juni en eerste week van juli verzameld, aangevuld met een momentopname van de bereikte lengte. Alleen op basis van de strandbemonsteringen in 2019 en 2020 is groei over het begin van het groeiseizoen te bepalen (Figuur 5.31), alleen wordt dit sterk beïnvloed door aankomst van nieuwe kleine schol en de migratie van grotere schol naar dieper water. De gemiddelde lengtes liggen lager dan die in Mengedoht (1995), maar vergelijkbaar met de voorspelde waardes in Meeuwissen (2014). Op basis van hetzelfde model als in Meeuwissen (2014), is de groei van schol in de verschillende kustvakken in ieder geval tot juni vergelijkbaar aan de voorspelde maximumwaardes bij optimale voedselcondities.

De dichtheden van de verschillende juni/juli bemonsteringen vergelijken met de resultaten uit andere studies wordt bemoeilijkt door de grote seizoensvariatie met in de meeste gebieden de hoogste dichtheden in de periode april-juni. De piek wordt beïnvloed door de condities tijdens de paaiperiode en de pelagische fase (Teal e.a., 2008) en kan dus verschillen tussen gebieden en jaren. Daarnaast is er duidelijke jaar-op-jaar variatie in dichtheden (van der Veer e.a., 2011). Een deel van deze variatie wordt bepaald door de absolute aanvoer van larven, maar is ook afhankelijk van de verdeling van de larven over de kinderkamers (Bolle e.a., 2009). Dit laatste wordt sterk bepaald door de omstandigheden tijdens de pelagische fase. Zo kan het verschil in het belang van de kinderkamers van de Belgische kust naar de Duitse Bocht grotendeels verklaard worden door de locaties van de paaigebieden en vervolgens door de drift van de eieren en larven langs de kust naar het noorden (van Beek e.a., 1989).

Een ander punt dat vergelijken van de dichtheden lastig maakt is de vangstefficiëntie van de gebruikte vistuigen. De gebruikte tuigen binnen Natuurlijk Veilig verschillen, maar ook met de tuigen gebruikt in vergelijkbare studies. Daar komt bij dat de meeste gegevens van het NIOZ worden weergegeven als gecorrigeerde aantallen op basis van vangstefficiëntie-experimenten (Kuipers, 1975; Dapper, 1978). Om een vergelijking te kunnen maken zijn de gegevens van het veldwerk in Natuurlijk Veilig gecorrigeerd met dezelfde methode (Bijlage 10). De correctie is bruikbaar voor een $2 \mathrm{~m}$ boomkor met één wekkerketting en $10 \mathrm{~mm}$ maaswijdte, vergelijkbaar met de meeste tuigen gebruikt in het veldwerk voor Natuurlijk Veilig. Kuipers (1978) kwam tot de conclusie dat de totale efficiëntie het 
resultaat is van twee factoren, namelijk verstoring veroorzaakt door de boot en zijwaartse ontsnapping. Er werd door Kuipers (1978) geen bewijs gevonden voor een effect van meerdere wekkerkettingen of van ontsnapping onder het net door, wellicht het gevolg van het feit dat op vlakke wadplaten gevist werd waar het vistuig gemakkelijk in het sediment zakt (Aarts e.a., 2019). Met name in de brandingszone, waar golven invloed hebben op de stabiliteit van het tuig, kan ontsnapping onder het tuig door waarschijnlijk plaatsvinden. In de strandbemonstering van 2020 zijn twee boomkorren verschillend in gewicht, met en zonder verzwaarde grondpees, gebruikt. Er werden (nog niet gekwantificeerd) verschillen in vangst waargenomen tussen deze twee tuigen. Aarts e.a. (2019) suggereren op basis van Reiss e.a. (2006) dat 63\% van de platvis onder het tuig door ontsnapt, en gebruiken deze als extracorrectie voor vangsten van de DFS-survey. Het kornet gebruikt tijdens de strandbemonstering in 2019 heeft vanwege het beperktere bodemcontact waarschijnlijk een nog lagere vangstefficiëntie voor platvis. Desalniettemin, zijn ook deze vangsten gecorrigeerd met de methode voor de $2 \mathrm{~m}$ boomkor.

$\mathrm{Na}$ correctie liggen de gemiddelde dichtheden in juni en half juli per gebied en tuig tussen de 2,4 tot 80,6 schol per $1000 \mathrm{~m}^{2}$, met een gemiddelde van 24,6 schol per $1000 \mathrm{~m}^{2}$. De maximumwaarde, aangetroffen tijdens de 2017 bemonsteringen bij Noord-Holland, is 334 per $1000 \mathrm{~m}^{2}$ (Tabel 6.1).

Tabel 6.1 De minimum, gemiddelde en maximum gecorrigeerde aantallen schol per $1000 \mathrm{~m}^{2}$ per gebied en gebruikte tuig in juni/juli. Aangevuld met de aanvullende correctie van de maximumwaardes op basis van de ontsnapping van platvis onder het tuig zoals genoemd in Aarts e.a. (2019).

\begin{tabular}{|c|c|c|c|c|c|c|c|}
\hline Jaar & Gebied & Tuig & trekken & $\min$ & gemiddeld & $\max$ & max (Aarts) \\
\hline \multirow[t]{6}{*}{2017} & Zuid-Holland & $2 \mathrm{~m}$ boomkor & 11 & 0 & 2.42 & 10.26 & 27.72 \\
\hline & & $3 \mathrm{~m}$ boomkor & 14 & 0 & 2.85 & 10.82 & 29.24 \\
\hline & Noord-Holland & $2 \mathrm{~m}$ boomkor & 14 & 4.61 & 80.61 & 288.69 & 780.24 \\
\hline & & $3 \mathrm{~m}$ boomkor & 20 & 8.05 & 74.94 & 334 & 902.71 \\
\hline & Texel & $3 \mathrm{~m}$ boomkor & 20 & 2.95 & 52.22 & 220.25 & 595.28 \\
\hline & Ameland & $3 \mathrm{~m}$ boomkor & 8 & 2.55 & 22.71 & 49.23 & 133.05 \\
\hline \multirow[t]{2}{*}{2018} & Schiermonnikoog & $2 \mathrm{~m}$ boomkor & 12 & 0 & 2.57 & 20.78 & 56.17 \\
\hline & & $3 \mathrm{~m}$ boomkor & 20 & 18.99 & 78.76 & 228.66 & 618 \\
\hline \multirow[t]{9}{*}{2019} & Katwijk & $\begin{array}{l}1,5 \mathrm{~m} \\
\text { boomkor }\end{array}$ & 12 & 0 & 21.07 & 68.89 & 186.19 \\
\hline & & kornet & 12 & 0 & 19.16 & 83.16 & 224.75 \\
\hline & Castricum & $\begin{array}{l}1,5 \mathrm{~m} \\
\text { boomkor }\end{array}$ & 12 & 0 & 31.17 & 109.94 & 297.12 \\
\hline & & kornet & 12 & 0 & 37.92 & 107.47 & 290.46 \\
\hline & Zuid-Holland & $3 \mathrm{~m}$ boomkor & 35 & 0 & 4.09 & 53.18 & 143.73 \\
\hline & Noord-Holland & $3 \mathrm{~m}$ boomkor & 32 & 0 & 19.74 & 139.33 & 376.57 \\
\hline & Texel & $1 \mathrm{~m}$ boomkor & 3 & 0 & 3.88 & 11.63 & 31.43 \\
\hline & & kornet & 12 & 0 & 10.22 & 29.69 & 80.24 \\
\hline & & $3 \mathrm{~m}$ boomkor & 2 & 2.1 & 2.49 & 2.88 & 7.77 \\
\hline \multirow[t]{5}{*}{2020} & Noord-Holland & $3 \mathrm{~m}$ boomkor & 48 & 0 & 15.98 & 83.73 & 226.3 \\
\hline & Texel & $3 \mathrm{~m}$ boomkor & 14 & 0 & 7.91 & 17.33 & 46.84 \\
\hline & Malzwin & $3 \mathrm{~m}$ boomkor & 9 & 0 & 9.51 & 26.15 & 70.68 \\
\hline & Balgzand & $3 \mathrm{~m}$ boomkor & 10 & 0 & 17.6 & 47.8 & 129.19 \\
\hline & IJmuiden & $2 \mathrm{~m}$ boomkor & 18 & 0 & 23.75 & 142.3 & 384.7 \\
\hline
\end{tabular}

In de Waddenzee, met name Balgzand (Van der Veer e.a., 1994; Van der Veer e.a., 2000; van der Veer e.a., 2011; Poiesz e.a., 2019) maar ook in andere gebieden (Jager e.a., 1993; Jager e.a., 1995), werden over de jaren heen substantiële dichtheden, variërend van enkele tientallen tot $~ 1400$ schollen per $1000 \mathrm{~m}^{2}$, aangetroffen. De NIOZ-vangsten op het Balgzand van alleen juni en half juli geven over de jaren $(75,76,79-82,86,91,93-98,2000)$ een gemiddelde van 78,6 per $1000 \mathrm{~m}^{2}$, en een maximum van 1262,7 per $1000 \mathrm{~m}^{2}$. Deze gemiddelde vangsten zijn vergelijkbaar met de 
gemiddelde vangsten bij Noord-Holland in 2017 en die met de 3 m boomkor in 2018 bij Schiermonnikoog.

De maximum NIOZ-vangsten liggen wel duidelijk hoger dan die wij in de kustzone hebben aangetroffen maar komen ook niet in alle bemonsterde jaren voor en zijn veel al registratie van de vorige eeuw. Als de extracorrectie voor ontsnapping onder het net wordt toegepast dan komen de maximumwaardes in de kustzone in de richting van de maximumwaardes van het NIOZ. De maximumwaardes aangetroffen door het NIOZ zijn vergelijkbaar met die aangetroffen in een baai van het Eiland Man (Nash en Geffen, 2000) en langs de Schotse westkust (Iles en Beverton, 1991), maar lager dan in een Zweedse baai (Iles en Beverton, 1991), en hoger dan in een Engelse oostkust baai (Iles en Beverton, 1991).

Aan de andere kant van de Nederlandse Waddenzee bij de Dollard, lagen de (ongecorrigeerde) dichtheden in juni/juli 1992-94 onder de 20 per $1000 \mathrm{~m}^{2}$ (Jager e.a., 1993; Jager en Kleef, 1999). In 1994 werd er zelfs nauwelijks schol gevangen in de Dollard, deze beperkte vangsten lagen waarschijnlijk aan de lage zoutgehaltes op dat moment (Jager en Kleef, 1999).

In 1992, werden aan de westkant van Texel vergelijkbaar met de locaties waar voor Natuurlijk Veilig is bemonsterd van maart tot oktober op dieptes van 2 tot 10 meter monsters genomen met een $2 \mathrm{~m}$ boomkor. De eerste scholletjes werden gevangen in mei. De gecorrigeerde dichtheden waren midden juni het hoogst, en varieerde tussen de 250-500 schol per $1000 \mathrm{~m}^{2}$. Deze dichtheden namen vervolgens af tot 100 per $1000 \mathrm{~m}^{2}$ in augustus (Mengedoht, 1995).

De jaarklassterkte van schol in de bemonsterende jaren was goed tot zelfs zeer goed (ICES, 2021). Terwijl de dichtheden in juni/juli uit de Natuurlijk Veilig bemonsteringen aan de lage kant liggen in vergelijking met de gegevens uit andere gebieden uit eerdere jaren.

De in 2020 op het Balgzand gevangen schol zijn in dichtheden vergelijkbaar met die van NoordHolland en zelfs iets lager dan die op min of meer hetzelfde moment gevangen vanaf het strand bij IJmuiden. Gezien de aangetroffen dichtheden en de indicatie dat in de vooroever maximale groei wordt bereikt, lijkt erop te duiden dat de habitatkwaliteit vergelijkbaar is tussen de Waddenzee en de vooroever. Hiermee heeft de Waddenzee alleen op basis van oppervlakte een groter belang voor de Noordzeepopulatie schol. Met de eerder gevonden 13-20\% van de schollen afkomstig uit de vooroever heeft deze een substantieel belang voor de Noordzeepopulatie van schol.

Daarbij komt dat recentere bemonsteringen van het NIOZ in de Waddenzee een verschuiving naar diepere gebieden laten zien (Freitas e.a., 2016). De in deze diepere gebieden in juni/juli aangetroffen dichtheden van schol waren hoger dan de hoogste gemiddelden in de vooroever. Maar geven ook aan dat het oppervlakte van de Waddenzee beschikbaar als kinderkamer voor schol veranderd is. In het volgende hoofdstuk wordt hierop verder ingegaan in relatie tot klimaatscenario's.

Voor tong zijn minder gegevens beschikbaar dan voor schol, met name in het Noordzeegebied. Tong heeft een zuidelijke verspreiding en veel van het onderzoek aan de kinderkamerfunctie voor tong vindt plaats in de Tagus estuarium (Vinagre e.a., 2009), Golf van Biskaje (Koutsikopoulos e.a., 1989; Le Pape e.a., 2003), en het Kanaal. Voor de Noordzee heeft van Beek e.a. (1989) op dezelfde manier en met dezelfde data als voor schol het belang van de Nederlandse kustzone ten opzichte van andere gebieden bepaald. Op basis van deze analyse kwam 35\% van alle tong uit de Duitse Bocht, 31\% vanaf de Nederlandse kust, $\sim 20 \%$ uit de Waddenzee en $\sim 12,4 \%$ vanaf de Belgische kust. Voor tong had de Nederlandse kust dus een veel groter belang dan voor schol. Deze verhouding wordt echter niet weerspiegeld in de Natuurlijk Veilig bemonsteringen waarin met name juveniele tong op het Balgzand, Waddenzee, is gevangen. Op het Balgzand was de gecorrigeerde gemiddelde dichtheid 38,3 tong per $1000 \mathrm{~m}^{2}$, dit zijn vergelijkbare dichtheden als aangetroffen in eerdere jaren op het Balgzand. Hier werden begin juli piekdichtheden aangetroffen tussen de 20 en de 100 tong per $1000 \mathrm{~m}^{2}$, behalve voor het uitzonderlijke jaar 1991 toen er 350 tong per $1000 \mathrm{~m}^{2}$ werden gevangen (van der Veer e.a., 2001). Dit zijn hogere dichtheden dan werden gevangen in het Tagus estuarium, waar gemiddelde dichtheden in de getijdengeulen werden gevangen van $\sim 6$ tong per $1000 \mathrm{~m}^{2}$, en op de moddervlaktes maar 0,4 tong per $1000 \mathrm{~m}^{2}$ (Vinagre e.a., 2009). Dit zijn dichtheden die vergelijkbaarder zijn met de 
dichtheden die tijdens Natuurlijk Veilig in de vooroever zijn aangetroffen, van 0 bij kustvak ZuidHolland tot $~ 9,9$ tong per $1000 \mathrm{~m}^{2}$ in de $2 \mathrm{~m}$ boomkor in kustvak Noord-Holland.

Met lengtes van 3,5-8 cm en een gemiddelde van $5,5 \mathrm{~cm}$ waren de tongen op het Balgzand gevangen op 22 juni 2020 groot en lijkt de groei voor te lopen op de resultaten uit eerdere jaren (van der Veer e.a., 2001). Ondanks de beperkte vangsten van 0-groep tong langs de kust hadden deze wel vergelijkbare lengtes als die van het Balgzand, met een gemiddelde lengte van $5,5 \mathrm{~cm}$ in de kustlangse bemonstering in Noord-Holland in beide jaren tezamen. Op basis van de bereikte lengtes lijkt de kustzone dus vergelijkbaar in kwaliteit met het Balgzand.

Voor beide soorten is het met de beschikbare gegevens lastig in te schatten wat het absolute belang van de vooroever is voor de populatie. Daarbij komt dat het belang over tijd waarschijnlijk is veranderd en, zoals in het volgende hoofdstuk besproken wordt, verder zal veranderen. Voor beide soorten is het duidelijk dat het gebied van substantieel belang is voor de Noordzeepopulaties en dat het gebied dat nog steeds is ondanks de suppletieactiviteiten die al plaatsgevonden hebben. 


\section{$7 \quad$ Toekomstig groeipotentieel van platvis in ondiepe kustwateren in verschillende klimaatscenario's}

\section{$7.1 \quad$ Introductie}

Natuurlijk Veilig (NV) onderzoekt de waarde van de Nederlandse ondiepe kustzone als kinderkamer voor jonge vissen in relatie tot de geplande zandsuppleties. De zandsuppleties zijn nodig om de zeespiegelstijging tegen te gaan. Het veldwerk en het in eerdere hoofdstukken beschreven onderzoek heeft zich gericht op de vissoorten die momenteel aanwezig zijn in het kustecosysteem. Klimaatverandering kan echter ook gevolgen hebben voor de habitatkwaliteit van de kustzone voor deze soorten. Klimaatverandering zal waarschijnlijk leiden tot een hogere watertemperatuur, vooral in ondiepe wateren.

Hier onderzoeken we hoe veranderingen in de zeewatertemperatuur de habitatkwaliteit van de kustzone beïnvloedt voor schol en tong. Omdat temperatuur het groeipotentieel van schol en tong beïnvloedt (Ciotti e.a., 2013a), gebruiken we een temperatuurafhankelijk Dynamisch Energie Budget (DEB) model om de mogelijke veranderingen in de groei van jonge schol en tong (leeftijd 0 en 1 jaar) in de kustzone te onderzoeken. Het DEB-model is een vereenvoudigde versie van het model dat oorspronkelijk is gedefinieerd door van der Veer e.a. (2009). Het model is eerder gebruikt voor de beoordeling van het groeipotentieel van platvis in diepere delen van de Noordzee (Teal e.a., 2012). Hier worden parameterwaarden gebruikt zoals afgeleid door Freitas e.a. (2010) en Teal e.a. (2012). Het model dat we gebruiken houdt rekening met directe effecten van temperatuur op de fysiologie van de vissen, maar houdt geen rekening met indirecte effecten van temperatuur op de voedselbeschikbaarheid (productiviteit van het benthos). We gebruiken voor beide leeftijdsklassen van de platvis een constant voedingsniveau gedurende het hele seizoen. Bovendien zijn de analyses gebaseerd op de aanname dat, behalve de temperatuur, de andere omstandigheden zullen blijven zoals ze in voorgaande jaren waren.

Gebruikmakend van IPCC-rapporten uit 2018 (IPCC, 2019) houden we rekening met veranderingen in de gemiddelde watertemperatuur van $+0,36$ en $+1,08^{\circ} \mathrm{C}$ in 2050 ten opzichte van 2015 . Daarnaast houden we rekening met een extreem toekomstscenario van $+1,80{ }^{\circ} \mathrm{C}$ verandering (zie paragraaf hieronder). We gebruiken resultaten van het ruimtelijke ZunoDD-model voor schattingen van de ruimtelijke en temporele temperatuurdynamiek in de waterkolom van 2003-2015 (Figuur 7.1). Het model is oorspronkelijk ontworpen voor de modelstudie MER Zandwinning (van der Kaaij e.a., 2017).

Hieronder presenteren we de resultaten van de DEB-analyse. Een beschrijving van het gebruikte model en de gebruikte parameterwaarden is te vinden in Bijlage 11.

\subsection{Temperatuurscenario's}

Aangezien er vanaf 2050 waarschijnlijk meer suppleties nodig zijn, wordt in de huidige analyse rekening gehouden met het groeipotentieel voor platvis in de kustzone vanaf 2050. In 2050 zal de wereldgemiddelde temperatuur van het zeeoppervlak met ongeveer $0,5^{\circ} \mathrm{C}$ (lage emissies) of $1,5^{\circ} \mathrm{C}$ (hoge emissies) zijn gestegen in vergelijking met de periode van 1986-2005 (IPCC, 2019). Als we ter vereenvoudiging uitgaan van een lineaire temperatuurstijging, vertaalt dit zich in een stijging van 0,01 en $0,03{ }^{\circ} \mathrm{C} / \mathrm{jaar}$. In een recente studie met klimaatmodellen van de Noordzee, wordt de temperatuurstijging in de Noordzee geschat op een mediane verandering van $4{ }^{\circ} \mathrm{C}$ in oppervlakte watertemperatuur tussen $1970-2100$ of $0,03^{\circ} \mathrm{C} /$ jaar voor het worstcasescenario (Dieterich e.a., 2019). Om deze stijging in oppervlakte watertemperatuur te vertalen in een stijging van de 
watertemperatuur bij de bodem, nemen we aan dat de stijging van de bodemtemperatuur gelijk is aan de stijging van de oppervlakte watertemperatuur. Dit is een aannemelijke aanname, gegeven dat er sterke vermenging optreedt van oppervlaktewater met de rest van de waterkolom in ondiep water. Bovendien zijn winterbodemtemperaturen langs de Nederlandse kust tussen 1981-2018 met ongeveer $0,05^{\circ} \mathrm{C} /$ jaar gestegen (Tinker e.a., 2020).

We gaan uit van drie scenario's met een lineaire stijging van de jaargemiddelde oppervlakte watertemperatuur tot 2050 van 0,01, 0,03 en 0,05 ${ }^{\circ} \mathrm{C} / \mathrm{jaar}$. De voorspelde stijging van de gemiddelde temperatuur in 2050 ten opzichte van 2015 is voor deze drie scenario's respectievelijk $+0,36{ }^{\circ} \mathrm{C}$, $+1,08^{\circ} \mathrm{C}$ en $+1,80^{\circ} \mathrm{C}$. We gaan ervan uit dat de seizoen- en jaarvariabiliteit niet zal veranderen ten opzichte van de periode 2003-2015. We voegen de stijging van de gemiddelde temperatuur toe aan de historische gegevens van 2003-2015 uit het ZunoDD-model om een ruimtelijke dimensie te krijgen van de verwachte verandering voor 2050 en daarna.
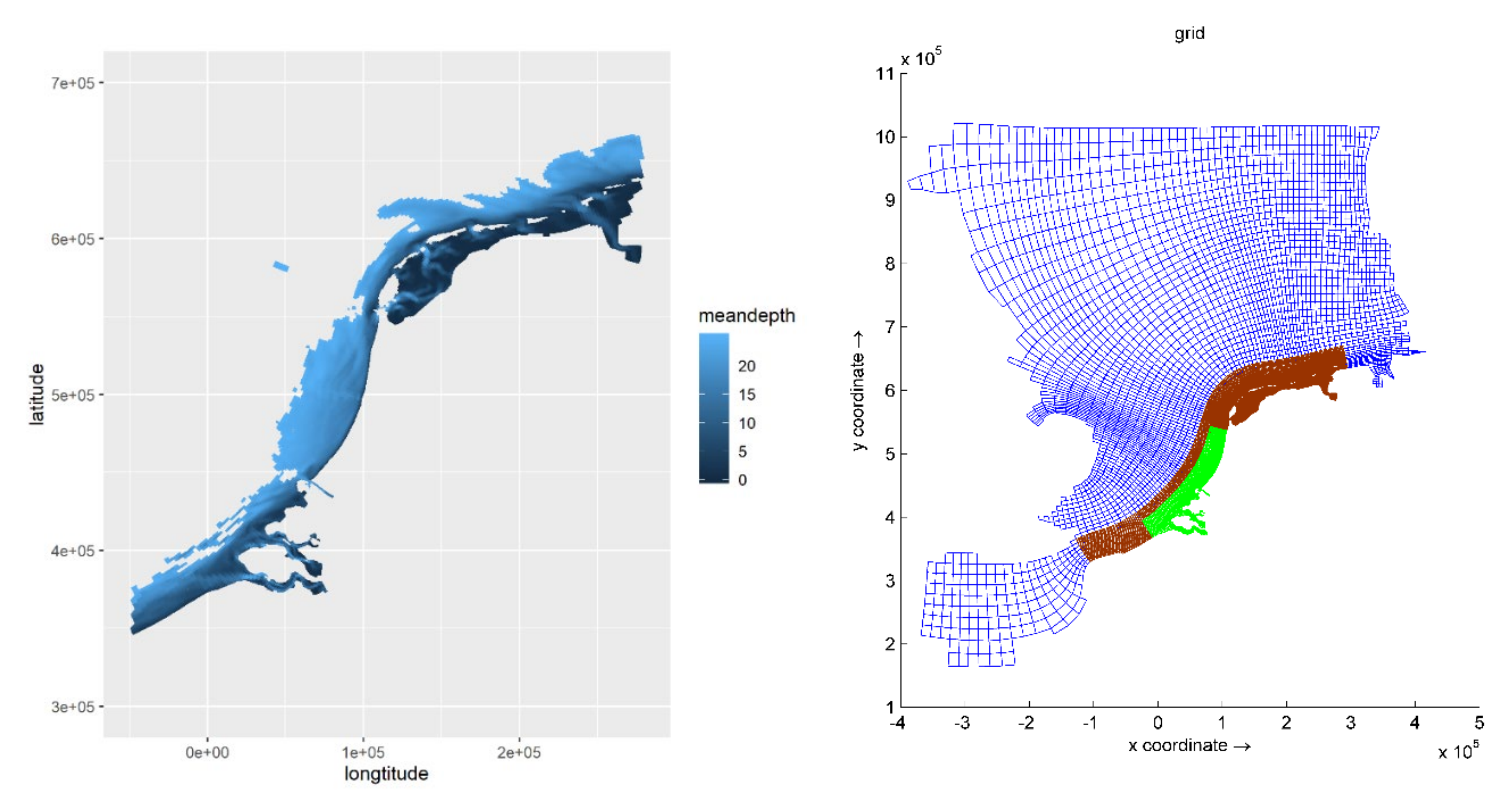

Figuur 7.1 Ruimtelijke gegevens uit het ZunoDD-model, temperatuurgegevens tussen 20032015. Links, diepteprofiel van gebieden met gemiddelde diepten < 25 meter per rastercel. Rechts, rastercel resolutie van ZunoDD-modeluitvoer gebruikt voor de onderstaande berekeningen.

Tabel 7.1 Definities groeiseizoenen (dag gerekend vanaf 1 januari) en lengtes aan het begin van de leeftijdsklassen voor schol en tong (zie Tabel B 4 en Tabel B 5 voor de onderbouwing van deze waarden).

\begin{tabular}{|c|c|c|}
\hline \multicolumn{3}{|l|}{ Schol - startlengte en groeiseizoen } \\
\hline \multirow{2}{*}{$\begin{array}{l}\text { Lengte aan de start van het } \\
\text { groeiseizoen }\end{array}$} & $1.5 \mathrm{~cm}-0$-groep & \\
\hline & $11 \mathrm{~cm}$ - 1-groep & \\
\hline \multirow{2}{*}{$\begin{array}{l}\text { Dag van het jaar waarop de } \\
\text { groeistart (settlement) }\end{array}$} & 105 - 0-groep & 16 april \\
\hline & 120 - 1-groep & $1 \mathrm{mei}$ \\
\hline \multirow[t]{2}{*}{ Laatste dag van groeiseizoen } & 227 - 0-groep & 16 augustus \\
\hline & 227 - 1-groep & \\
\hline \multicolumn{3}{|l|}{ Tong - startlengte en groeiseizoen } \\
\hline \multirow{2}{*}{$\begin{array}{l}\text { Lengte aan de start van het } \\
\text { groeiseizoen }\end{array}$} & $1.2 \mathrm{~cm}-0$-groep & \\
\hline & $12 \mathrm{~cm}$ - 1-groep & \\
\hline \multirow{2}{*}{$\begin{array}{l}\text { Dag van het jaar waarop de groei } \\
\text { start (settlement) }\end{array}$} & 183 - 0-groep & 3 juli \\
\hline & 120 - 1-groep & $1 \mathrm{mei}$ \\
\hline Laatste dag van groeiseizoen & $\begin{array}{l}300-0 \text {-groep, } 1- \\
\text { groep }\end{array}$ & 28 oktober \\
\hline
\end{tabular}




\subsection{Resultaten}

De gemiddelde temperatuur over alle ruimtelijke locaties met een gemiddelde diepte van minder dan 15 meter laat een duidelijk seizoenspatroon zien (Figuur 7.2), met lage temperaturen in de winter en hoge temperaturen in de zomer. De gemiddelde groei van zowel schol als tong vertonen een typisch seizoenspatroon. De groei versnelt eerst met de temperatuur, bereikt een optimum en neemt vervolgens weer af (Figuur 7.3). In relatief warme jaren (zoals 2003) daalt de groei van schol tegen het einde van het groeiseizoen. Voor tong vertoont de groeisnelheid ook een optimum in het midden van het seizoen, maar de afname is niet zo plotseling (Figuur 7.3). Schol is gevoeliger voor hoge temperaturen dan tong (zie groei bij hoge temperaturen tegen het einde van het groeiseizoen in 2003). Dit komt overeen met de verschillen in optimale temperatuur voor de groei van de twee soorten. Tong heeft zijn optimum rond de $25^{\circ} \mathrm{C}$, schol rond de $20^{\circ} \mathrm{C}$, deze optimale temperaturen verschuiven iets met de lengte (Figuur b 18).

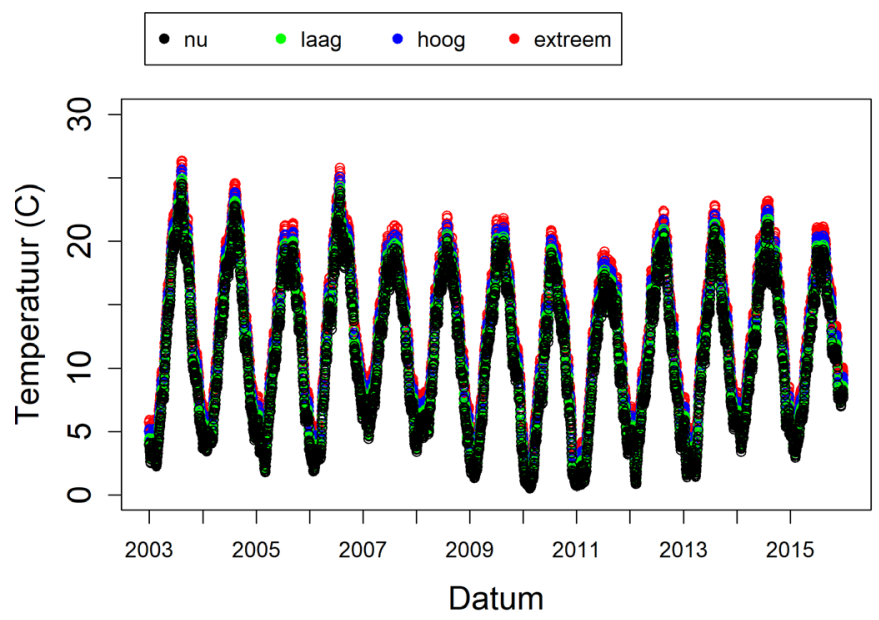

Figuur 7.2 Gemiddelde temperatuurpatroon over alle locaties met een gemiddelde diepte $<15 \mathrm{~m}$. Zwarte lijn is de gemodelleerde temperatuur voor de op de $x$-as weergegeven jaren. De drie kleuren zijn de verschillende klimaatscenario's, laag: 0,01; hoog: 0,03 en extreem: 0,05 ${ }^{\circ} \mathrm{C} / \mathrm{jaar}$.

Hogere temperaturen ten opzichte van het normale patroon leiden tot lagere groei in warme jaren voor zowel leeftijd 0 (A0) als leeftijd 1 (A1) van schol. Voor koudere jaren verhogen hogere temperaturen de groei en de lengte aan het einde van het groeiseizoen. Voor tong leiden verhoogde temperaturen onder alle omstandigheden tot een hogere groei en een hogere lengte aan het einde van het seizoen voor zowel A0 als A1 (Figuur 7.3).

De ruimtelijk expliciete resultaten laten een soortgelijk verhaal zien, maar seizoensgebonden veranderingen van de voorspelde groei zijn afhankelijk van de waterdiepte.

De hoogste groeisnelheid voor schol in 2003, een warm jaar, wordt voorspeld in ondiepe gebieden vroeg in het jaar (dag 185, schol A0: Figuur 7.4, Figuur 7.5, en schol A1: Figuur b 22). Later in het jaar (dagen 210, 235) zal de groei naar verwachting hoger zijn in dieper water waar het koeler is (Figuur 7.4, Figuur b 22). In 2011, een koud jaar (Figuur 7.2), is de groei voor schol het hele jaar door het hoogst in ondiepe gebieden (Waddenzee, Schelde en langs de kust) (Figuur 7.5).

Voor de klimaatscenario's is de groei van schol lager dan voor de normale situatie $(210,235$, Figuur 7.4, Figuur b 22). Schol A1 is duidelijk gevoeliger dan schol A0 voor temperatuurstijging, voor schol A1 is de groei in ondiepe gebieden, langs de kust, in de Waddenzee en de Schelde nog sterker verminderd voor de hoge en extreme klimaatscenario's in de zomer. Daarentegen hebben de klimaatscenario's een positief effect op de groei voor 2011, een koud jaar (Figuur 7.5) voor beide scholleeftijdsklassen (resultaten niet getoond voor schol A1). 

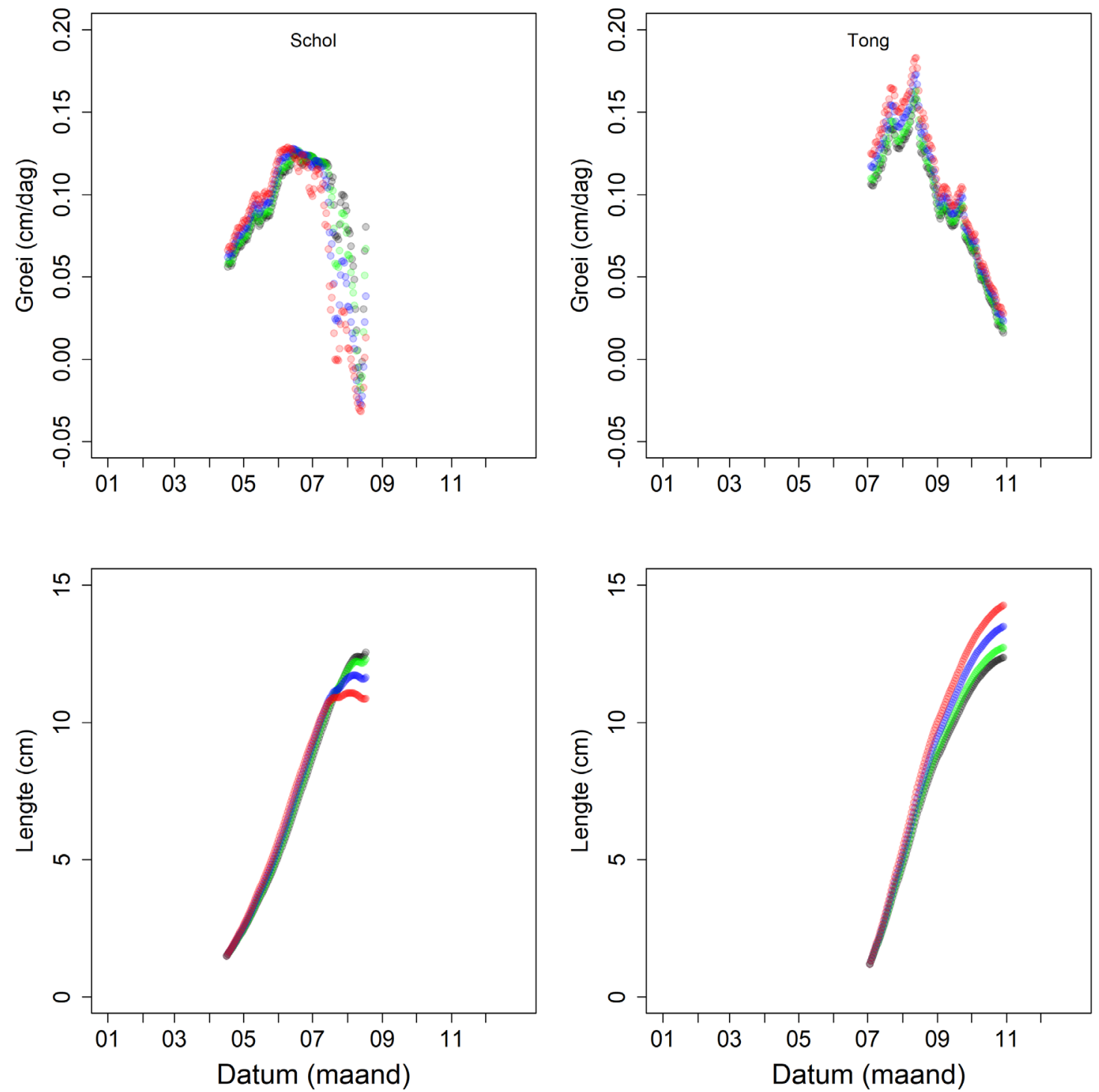

Figuur 7.3 Groeipatronen voor schol (links) en tong (rechts) in 2003 (een warm jaar), Leeftijd 0, voor gemiddelden over alle locaties <15 meter gemiddelde diepte in 2005. De periode voor de groeiseizoenen en lengte aan het begin van de groeiseizoenen verschillen tussen de soorten (Tabel 7.1: Schol A0: 105-227, 16 april - 16 augustus; Tong A0: 183-300, 3 juli - 28 oktober). De groei wordt weergegeven voor verschillende klimaatscenario's, huidig (zwart): model; laag (groen): +0,01; hoog (blauw): $+0,03$ en extreem (rood): $+0,05^{\circ} \mathrm{C} / \mathrm{jaar}$

Voor tong is de groei over het algemeen hoger in de ondiepe gebieden (Tong A0:Figuur 7.6, Figuur 7.7 en tong A1: Figuur b 25). Vroeg in het jaar wordt in de Schelde de meeste tonggroei voorspeld, vooral in 2011, een koud jaar (Figuur 7.7 en Figuur b 26). In tegenstelling tot schol is er voor tong geen seizoenverandering naar betere groeiomstandigheden in dieper water, behalve op dag 235 in 2003, een warm jaar, voor tong A0 (Figuur 7.6) en A1 (Figuur b 25), wanneer de groei in delen van de Waddenzee lager is dan in diepere gebieden. Het is onduidelijk of dit een temperatuureffect is (instroom van kouder water) of voortkomt uit een snellere groei eerder in het jaar die heeft geleid tot grotere individuen in deze gebieden (die langzamer groeien, Figuur b 18). De klimaatscenario's verhogen allemaal de voorspelde groei van tong (Tong A0:Figuur 7.6, Figuur 7.7 en Tong A1: Figuur b 25, Figuur b 26).

Voor schol kunnen de groeiomstandigheden bij hoge temperaturen zo ongunstig worden dat de voorspelde groei negatief wordt (Figuur b 18). In het baseline scenario, dus zonder temperatuurstijging, kwam er in enkele jaren zeer lokaal al negatieve groei voor (Figuur 7.8 en Figuur b 27). Voor de klimaatscenario's nemen de jaren en gebieden waarin negatieve groeicondities optreden toe. De groei langs de kust wordt door de klimaatscenario's minder negatief beïnvloed dan in de Waddenzee en de Schelde (Figuur 7.8 en Figuur b 27). Voor tong daarentegen verminderen de 
klimaatscenario's het aantal jaren met negatieve groeiomstandigheden, vooral voor tong A1 in de Waddenzee (Figuur 7.9, Figuur b 28).

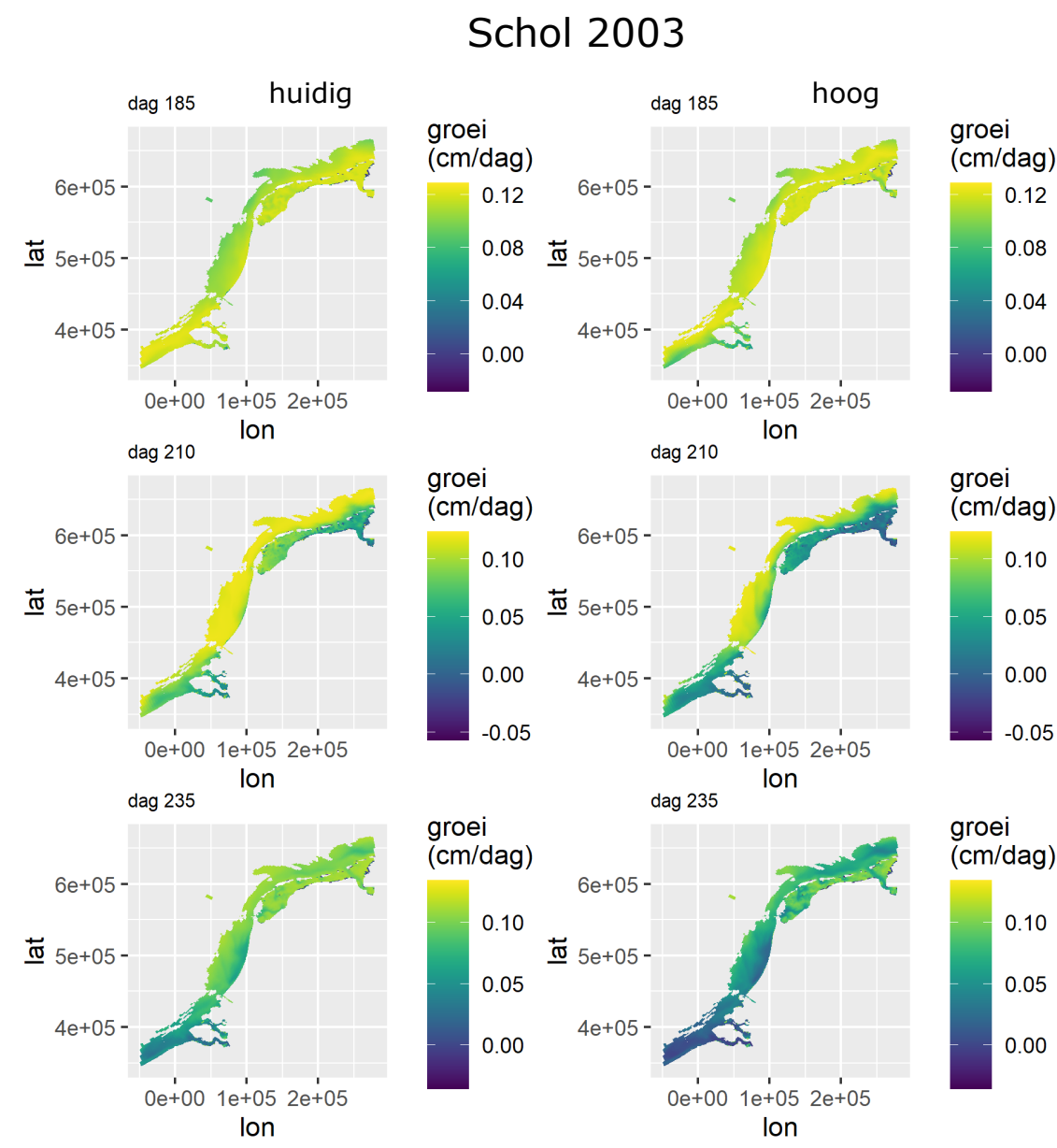

Figuur 7.4 Groeicondities van schol AO (aankomst op dag 105, 16 april) in een "warm" jaar (2003) voor gebieden met een gemiddelde diepte <25 m. Uitgezet zijn de dagen 185 (5 juli), 210 (30 juli) en 235 (24 augustus). De groei wordt weergegeven voor verschillende klimaatscenario's, huidig (links): model; hoog (rechts): $+0,03^{\circ} \mathrm{C} / \mathrm{jaar}$. 


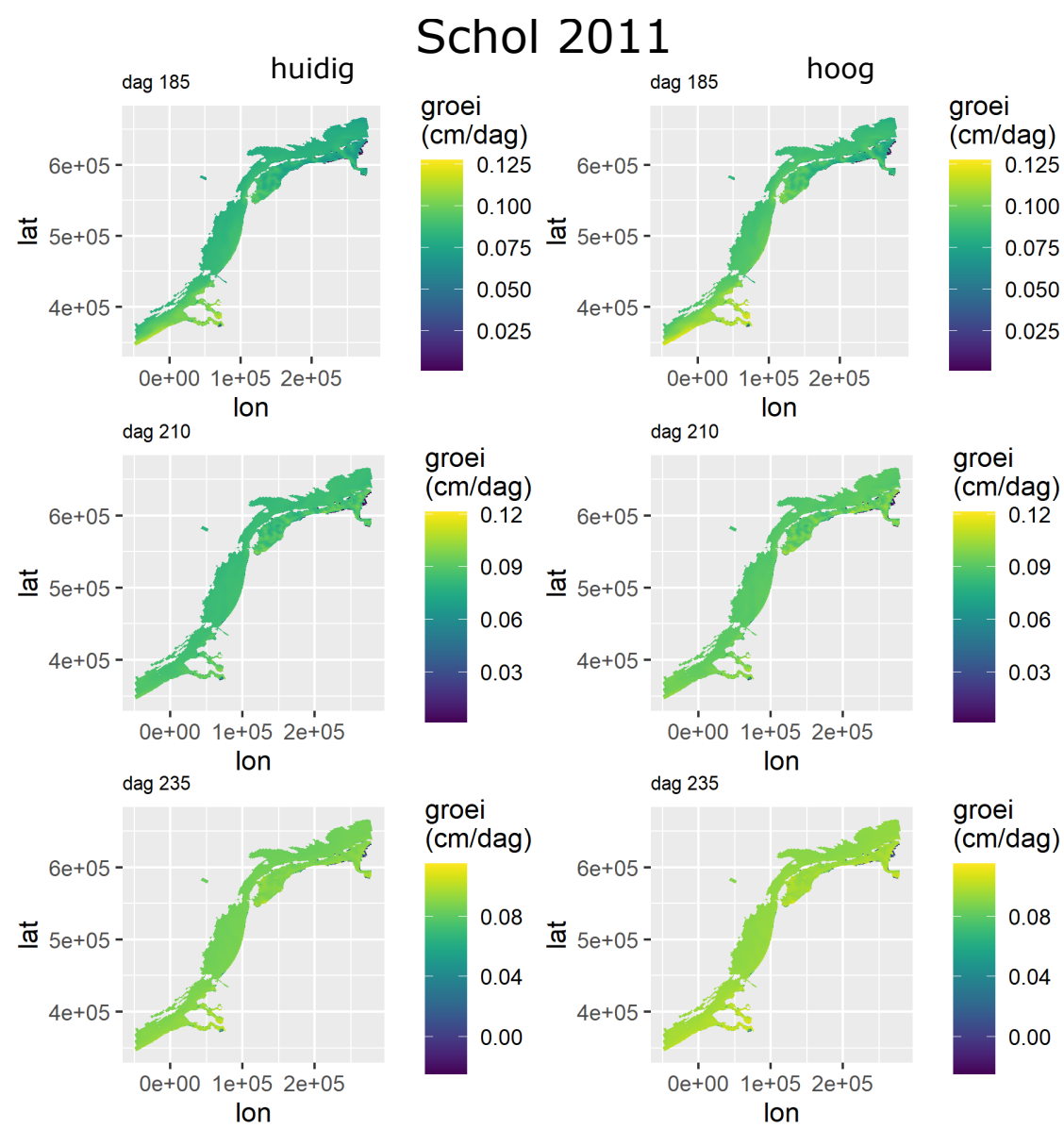

Figuur 7.5 Groeicondities van schol AO (aankomst op dag 105, 16 april) in een "koud" jaar (2011) voor gebieden met een gemiddelde diepte <25 m. Uitgezet zijn de dagen, 185 (5 juli), 210 (30 juli) en 235 (24 augustus). De groei wordt weergegeven voor verschillende klimaatscenario's, huidig (links): model; hoog (rechts): $+0,03^{\circ} \mathrm{C} / \mathrm{jaar}$.

Omdat de groei positief kan worden beïnvloed door de temperatuurstijging in koudere jaren voor schol, is het moeilijk te bepalen of er een netto positief of negatief effect is van de klimaatscenario's. Daarvoor is de voorspelde gemiddelde lengte aan het einde van het groeiseizoen over jaren (gedefinieerd als de eerste dag met nulgroei als dit voorkomt, of zoals gedefinieerd in Tabel 7.1) en de gemiddelde afwijking van normaal voor de klimaatscenario's weergegeven. Voor schol zien we vooral positieve effecten op de lengte aan het einde van het groeiseizoen voor A0 (Figuur b 29), behalve voor de ondiepe delen van de Schelde en de Waddenzee. Het gebied langs de kust lijkt minder last te hebben van de temperatuurstijging. Voor schol A1 (Figuur b 30) is het effect van de klimaatscenario's negatiever. In de klimaatscenario's wordt voorspeld dat de vissen aan het einde van het seizoen gemiddeld tot $0,4 \mathrm{~cm}$ kleiner ( 4\%) zullen zijn in de Waddenzee en de Schelde. Langs de kust blijft het gemiddelde effect op de lengte aan het einde van het seizoen voor alle klimaatscenario's positief. Voor tong voorspellen de klimaatscenario's alleen positieve effecten op de gemiddelde lengte (Figuur b 31,Figuur b 32). 


\section{Tong 2003}

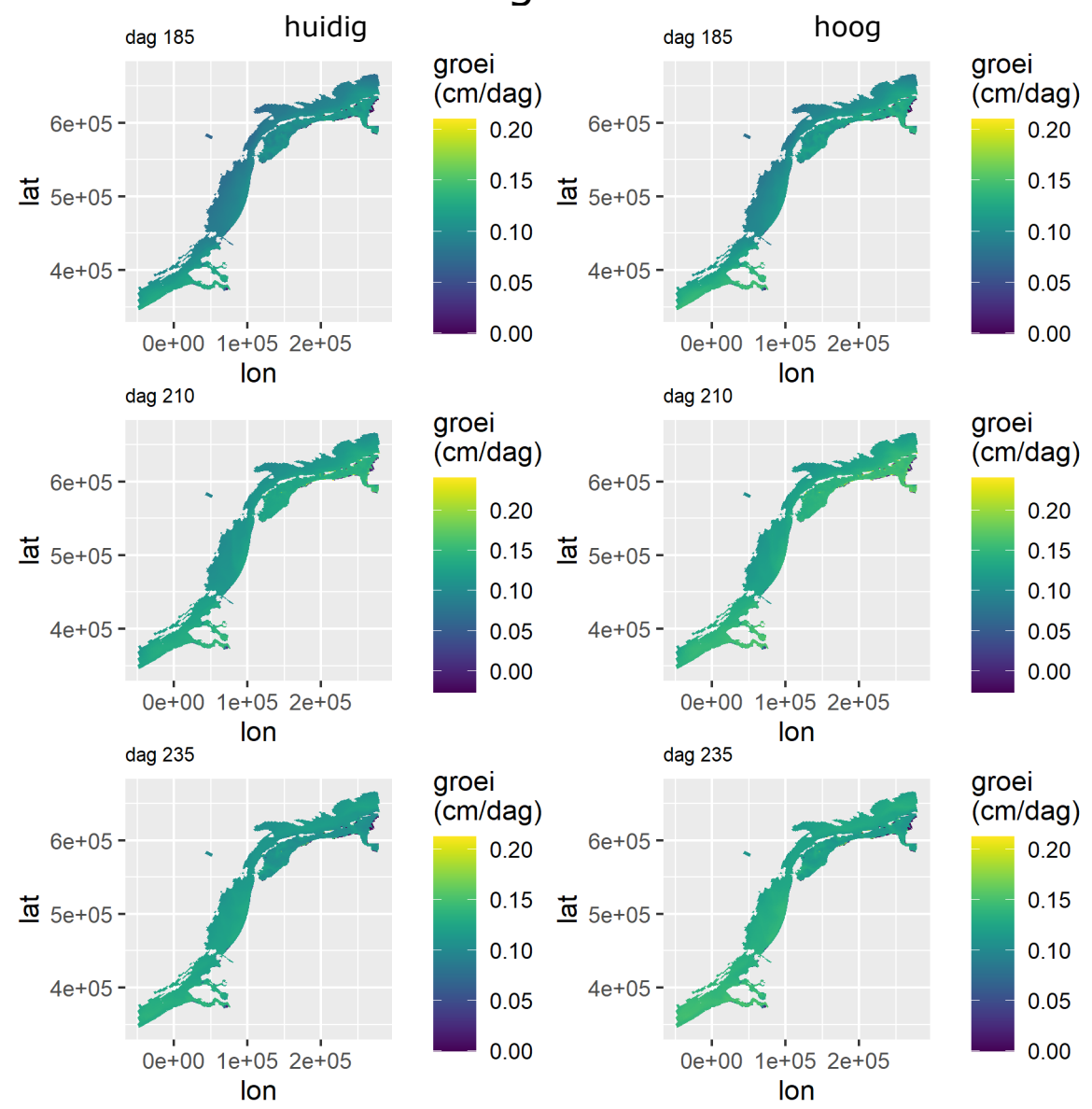

Figuur 7.6 Groeicondities van tong AO (aankomst op dag 90, 1 april) in een "warm" jaar (2003) voor gebieden met een gemiddelde diepte <25 m. Uitgezet zijn de dagen 185 (5 juli), 210 (30 juli) en 235 (24 augustus). De groei wordt weergegeven voor verschillende klimaatscenario's, huidig (links): model; hoog (rechts): $+0,03{ }^{\circ} \mathrm{C} /$ jaar. 


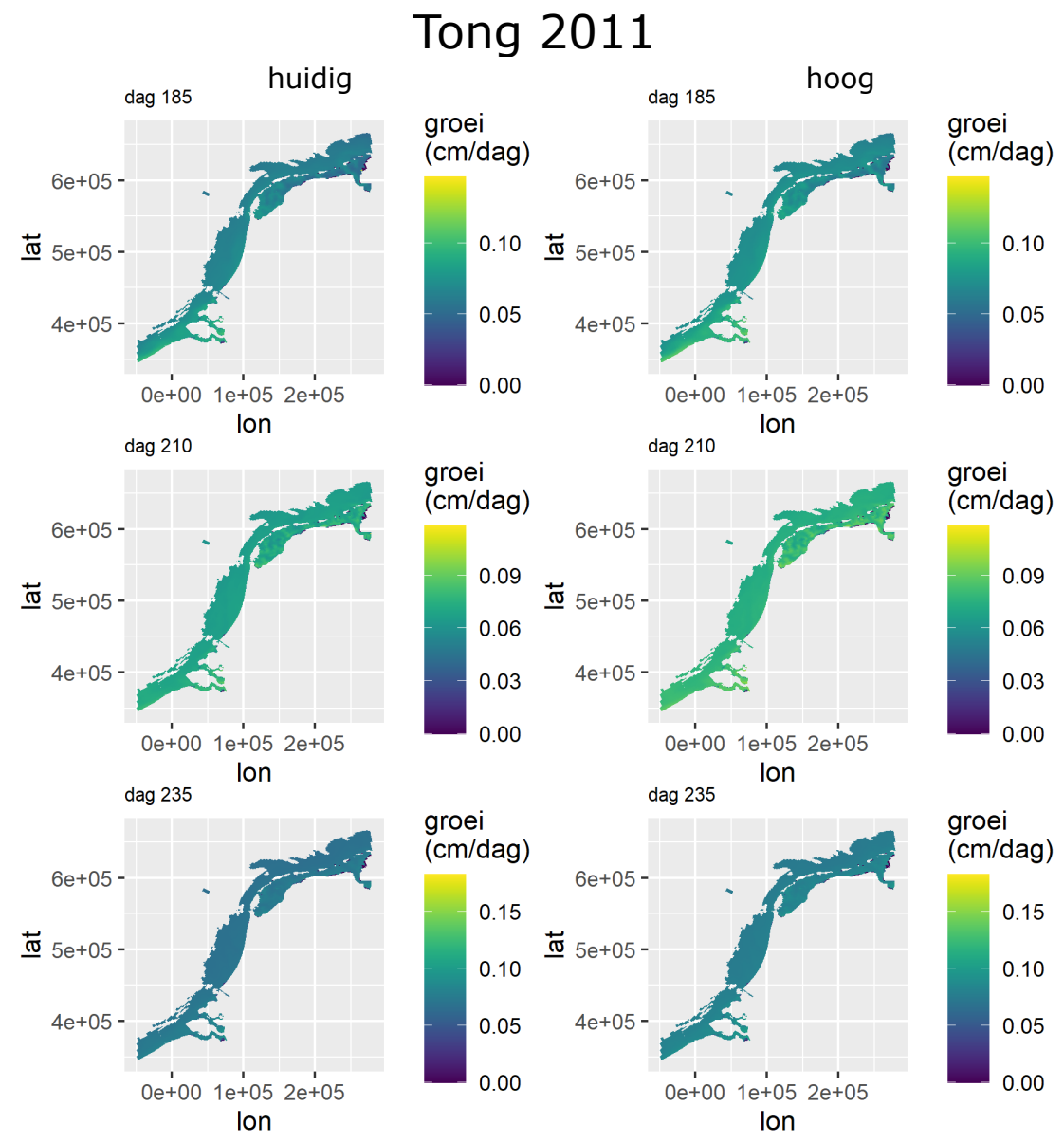

Figuur 7.7 Groeicondities van tong AO (aankomst op dag 90, 1 april) in een "koud" jaar (2011) voor gebieden met een gemiddelde diepte <25 m. Uitgezet zijn de dagen 185 (5 juli), 210 (30 juli) en 235 (24 augustus). De groei wordt weergegeven voor verschillende klimaatscenario's, huidig (links): model; hoog (rechts): $+0,03{ }^{\circ} \mathrm{C} /$ jaar. 


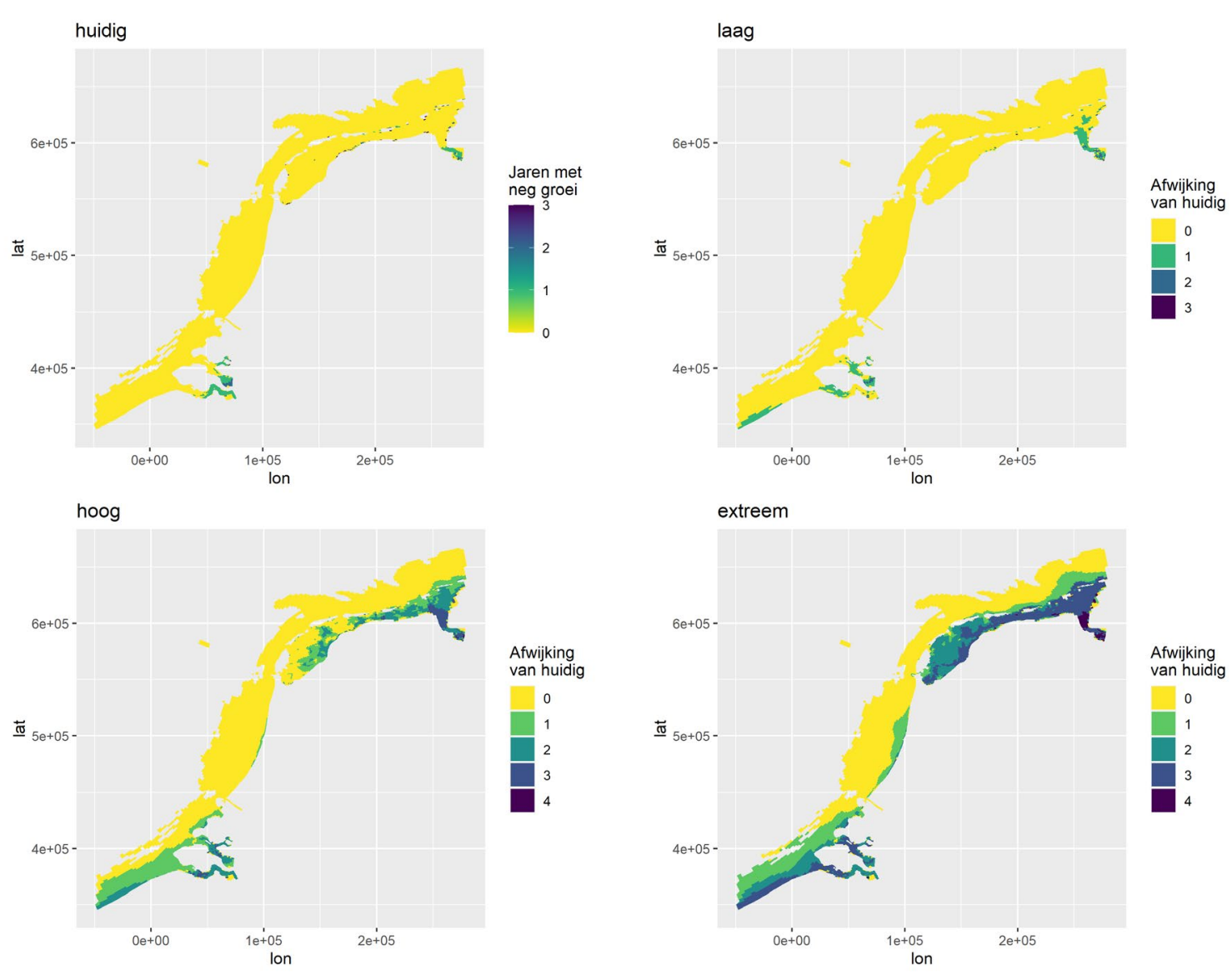

Figuur 7.8 Aantal jaren met negatieve groeiomstandigheden in het groeiseizoen (Schol A0: dag 105-227, 16 april - 16 augustus) voor gebieden met een gemiddelde diepte $<25 \mathrm{~m}$. We vergelijken het aantal jaren met negatieve groei in de data tussen 2003-2015 ("normaal") met de drie klimaatscenario's.

\subsection{Discussie}

De resultaten laten zien dat terwijl tong waarschijnlijk zal profiteren van toekomstige stijgingen in temperatuur, de groei van schol geremd kan worden als klimaatverandering leidt tot zeer hoge watertemperaturen $\left(23^{\circ} \mathrm{C}\right.$ of hoger) in de ondiepe zone. Vooral 1-jarige schol is gevoelig voor de temperatuurstijging, maar het effect is ook zichtbaar bij 0 -jarige schol. De negatieve effecten van de temperatuurscenario's zijn minder sterk zichtbaar langs de vooroever dan in de Waddenzee en de Scheldes. Dit betekent dat de vooroever bij toenemende temperaturen waarschijnlijk relatief van groter belang zal worden als kinderkamer van jonge schol. Temperaturen tegen de tolerantiegrens kunnen zorgen voor stress, waaronder de vissen gevoeliger worden voor veranderingen en aanpassing aan habitatomstandigheden. Beperkte veranderingen, die nu nog geen gevolgen hebben, zouden dan wel gevolgen kunnen hebben. Het is dus van belang te streven naar een kustsysteem wat ook onder temperatuurstress geschikt blijft voor juveniele vis.

Een negatief effect van temperatuur op de groeipotentie van 1- en 2- jarige schol is in eerdere analyses getoond (Teal e.a., 2012). De huidige studie, gebaseerd op een ruimtelijk meer gedetailleerd temperatuurmodel van het ondiepe water, laat op basis van vergelijkbare analyses de effecten van reële klimaatveranderingsscenario's zien.

De temperatuurtolerantie verschilt tussen schol en tong (Freitas e.a., 2010). Op basis van veldgegevens zijn aan temperatuur gerelateerde verschuivingen in de verspreiding van deze soorten beschreven (van Keeken e.a., 2007; Engelhard e.a., 2011; van Hal e.a., 2016). Gegevens over groei van 0-jarige tong en schol tussen 1970-2004 laten zien dat vooral tong kan profiteren van de hogere zomertemperaturen die voorkomen sinds 1989 (Teal e.a., 2008). Het is dus aannemelijk dat schol inderdaad gevoeliger zal zijn voor toekomstige temperatuurstijgingen dan tong. Ons model is gebaseerd op de aanname dat het voedselaanbod niet verandert door de temperatuurstijging. Er was geen informatie beschikbaar over de verwachte verandering in benthische 
productiviteit met de geprojecteerde temperatuurstijging. Verschillende mogelijke effecten van klimaatverandering op benthische dieren zijn waargenomen (Birchenough e.a., 2015), veel evertebraten die in de zandbodem van de Noordzee leven, vertonen een verschuiving richting het noordwesten (Hiddink e.a., 2015), naar relatief koeler water. Alhoewel tong een hogere groeipotentie laat zien met temperatuurstijging, is het dus nog maar de vraag of een verandering in het voedselaanbod door temperatuurstijging geen tegengesteld effect zal laten zien. Het zou natuurlijk ook kunnen, dat de benthische productiviteit stijgt door klimaatverandering, al dan niet met een andere soortsamenstelling (die dan ook eetbaar zou moeten zijn voor tong en schol). Een eerdere analyse van historische temperatuurtrends waarvoor wel benthische productiviteitschattingen waren, liet zien dat de groei van tong door voedsel kan worden gelimiteerd op sommige plekken in de Noordzee (Teal e.a., 2012).

Het Zuno model, dat we gebruiken voor de temperatuurtrends in het water, is gevalideerd op basis van temperatuurmetingen langs de Nederlandse en Belgische kust (Cronin e.a., 2013), maar niet op basis van temperatuurmetingen in de Waddenzee en de Schelde. Aangezien de watertemperatuur sterk afhankelijk is van de warmte-uitwisseling met de atmosfeer, wordt verwacht dat het model de watertemperatuur vrij nauwkeurig voorspelt. Dit neemt niet weg, dat de temperatuur van zeer ondiep stilstaand water, dat kan optreden zoals bij zandbanken in de Waddenzee, echter snel kan oplopen en daarom moeilijk door het model te voorspellen valt.

Het model is gebaseerd op het huidige diepteprofiel van de kustzone. Toenemende suppletiehoeveelheden leiden mogelijk tot veranderingen in het diepteprofiel, waarbij het waarschijnlijk is dat de ondiepste zones ondieper worden en gehele kustprofiel steiler. Het verondiepen heeft tot gevolg dat deze gebieden snel zullen toenemen in temperatuur dan in het huidige model is meegenomen.

Over het algemeen wordt aangenomen dat de predatiedruk voor kleine vis in dieper water hoger is dan in ondieper water (Ellis en Gibson, 1995). Een van de theorieën om de relatie tussen platvis lengte en diepte te verklaren, is dan ook dat kleinere platvis actief een habitat selecteert in ondieper water (Gibson e.a., 2011). In de herfst migreren platvissen naar dieper water (Poxton e.a., 1983). Als schol, onder invloed van hogere temperaturen, eerder en bij een kleinere lengte naar dieper water zou migreren dan ze nu doen, zou dit ertoe kunnen leiden dat de predatiedruk op juveniele schol toeneemt als de grotere vis niet ook naar nog dieper water moet migreren. Dat laatste lijkt minder noodzakelijk omdat het diepere water minder snel opwarmt dan de ondiepe kust.

Naast een stijging van de gemiddelde temperatuur door klimaatverandering, wordt ook gesproken over een mogelijke toename in de variatie van de temperatuur (Hunt en Elliott, 2004). Het is tot nu toe niet duidelijk hoe de toename in variatie en als gevolg daarvan het vaker voorkomen van extreme temperaturen zal doorwerken in de zeewatertemperaturen van de Noordzee. Ook is het onbekend hoe juveniele schol en tong zullen worden beïnvloed door uitschieters in temperatuur en wat precies de cues zijn voor hun seizoenmigratie naar dieper water.

Ten slotte, is het aannemelijk dat onder de invloed van klimaatverandering de datum van de recruitment-piek van larvale tong (van de Wolfshaar e.a., 2021) en waarschijnlijk ook schol zal verschuiven. Voor tong, zou de eerdere aankomst van de larven kunnen leiden tot snellere groei, maar ook tot een lagere overleving van de larven (van de Wolfshaar e.a., 2021). Of het netto-effect van klimaatverandering dus positief uitpakt voor tong, hangt ook af van de aankomstdatum van de tong larven.

\subsection{Samenvatting}

Samenvattend laten de resultaten zien dat klimaatveranderingsscenario's voor temperatuurstijging de groeiomstandigheden voor platvis in de kustwateren beïnvloeden. Het directe effect van temperatuurstijging op de groei van tong is naar verwachting positief. Tong groeit sneller en is groter aan het eind van het groeiseizoen in alle gebieden met alle klimaatscenario's die we hebben gebruikt. Aan de andere kant wordt voorspeld dat de groei van schol soms negatief en soms positief wordt beïnvloed door temperatuurstijging. Waar matig hoge temperaturen de groei van schol kunnen verhogen, verlagen extreem hoge temperaturen de groei van schol. Ondiepe wateren zijn doorgaans warmer en de negatieve effecten van temperatuurstijging worden vooral waargenomen in de EemsDollard en daarnaast in de Waddenzee en de Schelde, en minder in het ondiepe gedeelte langs de kust. Doordat we een vergelijking maken met een temperatuurpatroon zoals waargenomen tussen 
2003-2015, vinden we ook verschillen tussen jaren. Een temperatuurstijging in jaren die normaal koud zou zijn, beïnvloedt de scholgroei positief, terwijl in jaren die normaal gesproken al warm zouden zijn de temperatuurstijging leidt tot zeer ongunstige groeiomstandigheden voor schol. Het netto-effect van temperatuurstijging voor groei van schol is negatief voor schol in ondiep water. Aan het einde van het groeiseizoen is de grootte van 0-groep schol in ondiep water naar verwachting tot 0,5 cm kleiner dan in het scenario zonder temperatuurstijging (Figuur b 29). Voor 1-groep schol is dit zelfs tot $1,0 \mathrm{~cm}$ kleiner (Figuur b 30). De groeiomstandigheden in het ondiepe stuk langs de kust lijken altijd minder beïnvloed door temperatuurstijging dan in de Schelde en Waddenzee. In dieper water is het effect op de groei naar verwachting gemiddeld positief.
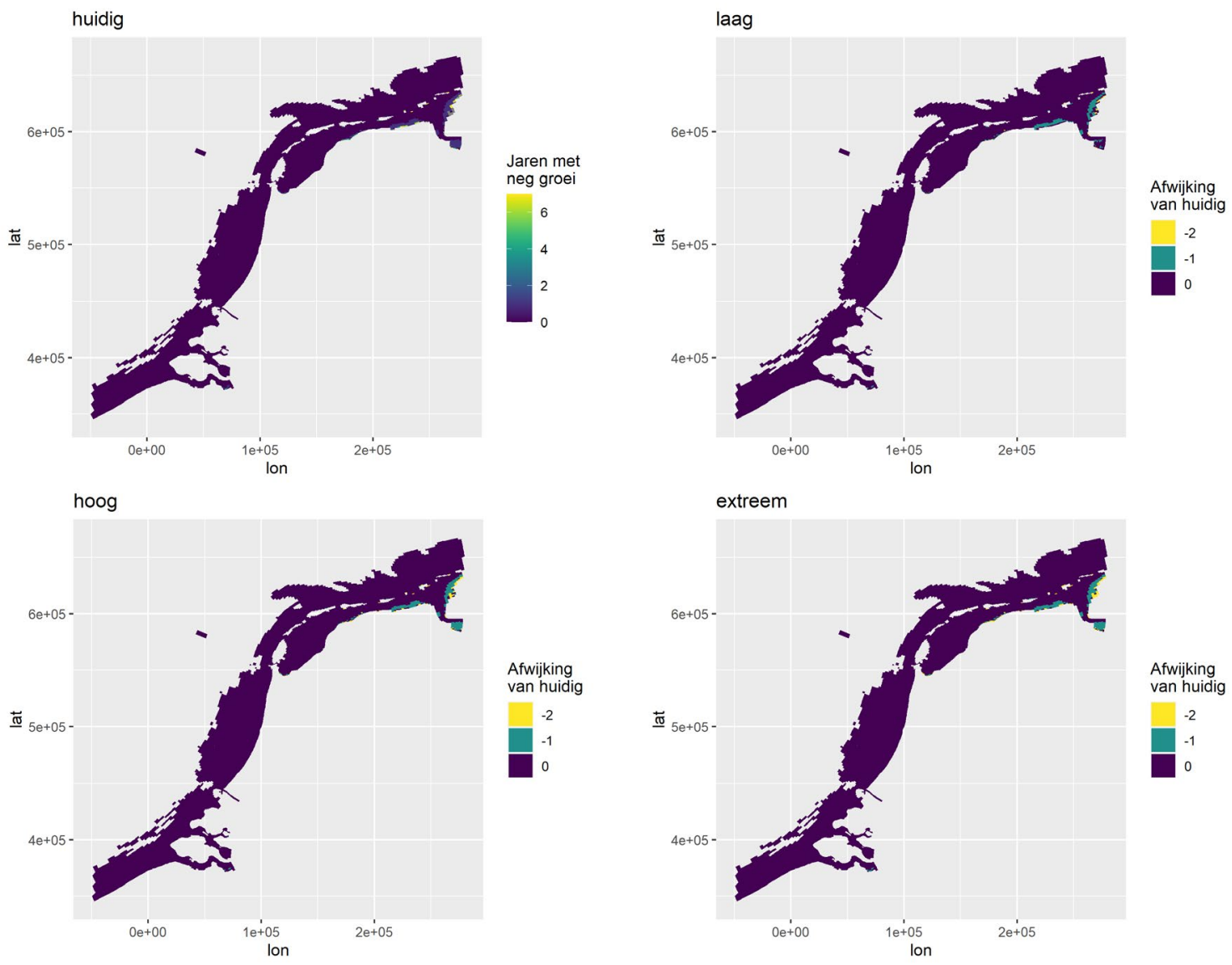

Figuur 7.9 Aantal jaren met negatieve groei in het groeiseizoen (tong A0: 183-300, 3 juli - 28 oktober) voor gebieden met een gemiddelde diepte $<25 \mathrm{~m}$. Het aantal jaren met negatieve groei in de data tussen 2003-2015 vergelijken we met de drie klimaatscenario's. 


\section{Conclusies en aanbevelingen}

\subsection{Soortensamenstelling in de vooroever}

De vooroever staat bekend als kinderkamer voor bodemgebonden vissen. De meest algemene demersale soorten die zijn aangetroffen in deze studie waren schol, kleine zeenaald, zandspiering, wijting, grondel, schar en tong. In minder mate werden ook de platvissen bot, tarbot en griet aangetroffen in de vangsten. De bemonsteringen uitgevoerd binnen het Natuurlijk Veilig project laten zien dat ook pelagische vissen de ondiepe kustzone als kinderkamer gebruiken. In de bemonsteringen gericht op demersale vis (boomkor en kornet) zijn in totaal 50 vissoorten aangetroffen, waarvan er 12 beschouwd worden als pelagische soorten. Uit de akoestische opnames in 2017 en 2018 bleek dat de pelagische vis sterk gefragmenteerd (in scholen) aanwezig was in de vooroever. Pelagische vis die met de bodemtuigen gevangen werd bestond vooral uit haring, sprot (Clupeidae), en zandspiering.

De gemiddelde vislengte lag tussen de 5 en $10 \mathrm{~cm}$ en de meeste vis was kleiner dan $20 \mathrm{~cm}$, een sterke aanwijzing dat hoofdzakelijk juveniele vis gevangen is. In de brandingszone werden naast de algemeen aangetroffen pelagische soorten haring en spot ook ansjovis, goudharder, koornaarvis, pelser en zeebaars aangetroffen.

De gebruikte bemonsteringsmethoden bepalen voor een deel wel welke soorten en lengtes er voornamelijk gevangen worden. Bijvoorbeeld grote snel zwemmende vis wordt met de gebruikte methodes nagenoeg niet gevangen. Desondanks is het beeld dat de genoemde soorten en vooral kleine vis het grootste deel van de visgemeenschap in de vooroever uitmaken.

Er was een grote variabiliteit in de vangsten. Zelfs op beperkte ruimtelijk schaal en tijd van twee in elkaars verlengde liggende trekken in de brandingszone werden geregeld andere soorten aangetroffen. Een zeer groot deel van de variabiliteit is op dit moment nog onverklaarbaar en waarschijnlijk een gevolg van kans. Een deel van de variatie in de brandingszone wordt verklaard doordat in de loop van het seizoen verschillende soorten zich vestigen, eerst schol in maart-april en pas later in het jaar tong, tarbot en griet. Ook de invloed van stormen en de watertemperatuur spelen waarschijnlijk een rol, wat echter lastig statistisch is aan te tonen. Dit wordt verder bemoeilijkt door de impact van vangstefficiëntie en de invloed van doorzicht daarop. De grote variatie in de vangsten noodzaakt het bemonsteren van grote aantallen stations om uit de variatie nog patronen te kunnen halen.

\subsection{Functioneren van de kustzone als opgroeigebied}

Om de geschiktheid van een gebied als opgroeigebied te kunnen meten, is het zinvol om metingen te doen aan de directe processen die de kwaliteit bepalen: immigratie, emigratie, groei en sterfte. Vanuit pragmatisch oogpunt is dat echter een intensieve en kostbare aanpak. In het onderzoek is er daarom gekozen om als resultante van die processen de visdichtheid als belangrijkste (respons)parameter te gebruiken voor in ieder geval de vier doelsoorten schol, tong, tarbot en griet. Daarnaast zijn er in enkele detailstudies metingen gedaan aan een aantal processen die de kwaliteit van de kinderkamer bepalen: groei en dieet.

\subsubsection{Vergelijking historisch en huidige dichtheden}

De analyses van de historische gegevens bieden de gelegenheid het functioneren van de kustzone over een langer tijdsbestek te evalueren. Uit deze analyses bleek dat juveniele schol gebruik maakte van de gehele vooroever, de resultaten impliceren wel dat de dichtheden hoger waren in de ondiepe kustwateren tot $5 \mathrm{~m}$. Juveniele tong leek nauwelijks gebruik te maken van het ondiepste water (0-2 $\mathrm{m}$ ). Hoogste dichtheden juveniele tong werden aangetroffen in de 2-5 m dieptezone, met toenemende diepte namen de dichtheden af. In tegenstelling tot tong, hadden tarbot en griet een duidelijke voorkeur om zich te vestigen in het ondiepste water $(0-2 \mathrm{~m})$ en verbleven hier het gehele jaar om op te groeien. 
De DFS tijdserie van de ruimtelijke verspreiding van juveniele platvis (schol en tong) in de kustzone laat sinds het begin van de bemonstering in 1970 veranderingen in de verspreiding van juveniele platvis zien. 0-groep schol werd in de eerste decennia van de DFS in het najaar in hogere dichtheden aangetroffen in de ondiepe kustwateren, meer recentelijk komt schol in het najaar in gelijke mate verspreid over de gehele kustzone voor. Ditzelfde geldt voor 0-groep tong, echter is de totale gemiddelde dichtheid van 0-groep tong in de Noordzeekustzone afgenomen. De verandering in gebruik van de kustzone betekent dat het gebied dat gebruikt wordt door net gevestigde platvis groter is dan voorheen, en de kinderkamer dus uitgebreider. Op basis van de gevangen lengtes lijkt groei in deze nieuwe gebieden vergelijkbaar, maar of de predatiedruk hoger is en daarmee de mortaliteit is onduidelijk. Voor schol kan het functioneren van de Noordzeekust als kinderkamer zijn toegenomen aangezien de totale gemiddelde dichtheden over de jaren heen vrijwel gelijk zijn gebleven. Voor tong zijn de totale dichtheden in de Noordzeekustzone afgenomen, hierdoor kan het zijn dat de kinderkamerfunctie voor tong is afgenomen.

De dichtheden juveniele schol die in de bemonsteringen binnen Natuurlijk Veilig gevonden zijn in de kustzone zijn, na correctie voor vangstefficiëntie, in dezelfde orde van grootte als dichtheden binnen hetzelfde seizoen (juni/juli) in andere opgroeigebieden zoals de Waddenzee. In de opgroeigebieden nemen de dichtheden vanaf het vroege voorjaar (maart-april) toe tot piekdichtheden in mei-juni, waarna de dichtheden weer (snel) afnemen.

Tong werd in veel lagere aantallen gevangen dan schol in de Natuurlijk Veilig bemonsteringen en werd helemaal niet aangetroffen in de vistrekken uitgevoerd in de brandingszone. In het beperkt aantal vistrekken uitgevoerd in de Waddenzee werden beduidend hogere dichtheden juveniele tong aangetroffen dan in de kustzone. Dit is niet in lijn met de constatering van van Beek e.a. (1989) dat de kustzone van groter belang was als kinderkamer voor tong dan de Waddenzee. Sinds die tijd zijn de dichtheden juveniele tong die gevangen worden in de kustzone wel afgenomen (Figuur 5.36). In de najaars-DFS in 2020 werd er langs de hele kustzone juveniele tong gevangen, in lage dichtheden die duidelijk lager zijn dan die in de jaren 1980. In de westelijke Waddenzee zijn in 2020 in tegenstelling tot 2019 juist wel hoge dichtheden jonge tong, in bijna alle uitgevoerd trekken, aangetroffen. De vangsten in de Westelijke Waddenzee waren een van de betere in de afgelopen 20 jaar. Dit maakt nogmaals duidelijk dat er grote jaarlijkse variatie is en een momentopname in een enkel jaar beperkt inzicht kan geven.

Tarbot en griet werden in zeer beperkte aantallen gevangen. Vanwege de geringe aantallen en om toch inzicht te krijgen in de diepteverspreiding is gebruik gemaakt van data uit meerdere monitoringsprogramma's. Hieruit wordt het beeld van een sterke voorkeur van juveniele tarbot en griet voor de ondiepe kustwateren $(0-5 \mathrm{~m})$ bevestigd.

\subsubsection{Huidig functioneren: relaties met habitat, groei en dieet}

Het functioneren van een gebied als kinderkamer wordt o.a. bepaald door processen die inwerken op groei en overleving. In het onderzoek hebben we vooral veel gemeten aan dichtheid in relatie tot abiotische omgevingsvariabelen om zodoende een habitatmodel op te stellen. De habitatmodellering liet zien dat de verspreiding van schol wel gestuurd wordt door saliniteit en doorzicht, maar niet door diepte of sedimentsamenstelling. Voor tong spelen doorzicht, sediment en saliniteit een rol in de verklaring van de verspreiding. Schar kwam voornamelijk in de diepere trekken voor en heeft een lichte voorkeur voor zouter water. De relaties met doorzicht en sediment zijn voor schar niet significant. Voor wijting was er een significante relatie met waterdiepte, waarbij ze vooral in water dieper dan $4 \mathrm{~m}$ voorkwamen en was er een negatieve relatie met doorzicht en blijkt er een positief verband met saliniteit (Tabel 8.1).

Soorten waarbij een relatie met sediment gevonden werd waren: tong, grondels en zandspiering (Tabel 8.1). Voor deze soorten kan een habitatmodel op basis van sediment gebruikt worden en zou de impact van een voorspelde toename in korrelgrootte op de dichtheden geanalyseerd kunnen worden. In het geval van tong waar een voorkeur voor slib is waargenomen, zou een vergroving leiden tot een afname in de habitatkwaliteit. Er moet echter voorzichtig omgegaan worden met gevonden relatie tussen slibgehalte en de hoeveelheid tong. Er zijn eerdere studies gedaan die de voorkeur voor hogere slibgehaltes en zeer fijn zand voor tong laten zien (Champalbert e.a., 1992; Post e.a., 2017), wat de gevonden relatie aannemelijk maakt. Echter, de door ons gevonden relatie is vooral gedreven door de hoge dichtheden aangetroffen in de Waddenzee. Tijdens de DFS in het najaar 
van 2020 werden er hoge aantallen tong in de Westelijke Waddenzee gevangen, deze dichtheden wijken positief af van veel van de andere jaren in de DFS tijdserie.

Tabel 8.1 Gevonden correlaties tussen omgevingsvariabelen en de dichtheden. + toenemende dichtheden bij een hogere waarde van de omgevingsvariabele; - afnemende dichtheden bij een hogere waarde van de omgevingsvariabele; +/- variabele relatie kan ook voorkomen omdat de GAM-methode een smoother oplevert die een flexibele vorm kan hebben (geen rechte lijn).

\begin{tabular}{l|ccccc} 
Soort & Korrelgrootte & Slibgehalte & Diepte & Saliniteit & Doorzicht \\
\hline Schol & & & & + & - \\
Tong & & + & & $+/-$ & - \\
Schar & & & + & + & - \\
Wijting & & & + & + & - \\
Kleine zeenaald & & & & & - \\
Grondel & - & & + & +
\end{tabular}

De hoge dichtheden in het voorjaar waren mogelijk een gevolg van jaarlijkse variatie (door larventoevoer) en niet direct gerelateerd aan de preferentie voor het hoge gehalte slib. Voor de soorten waarvoor geen relatie met de sedimentsamenstelling werd gevonden, zoals voor schol, is een habitatmodel niet in staat om de impact van door suppleties veranderde sedimentsamenstelling te analyseren. Tenzij de korrelgroottes veel grover worden dan nu zijn aangetroffen in de vooroever, wat niet aannemelijk is (Herman e.a., 2021), zouden er pas veranderingen in verspreiding van deze soorten verwacht kunnen worden. Dat er voor schol geen relatie gevonden werd met sediment was gezien de variatie in bemonsterde korrelgroottes (meerderheid tussen 150-450 $\mu \mathrm{m}$ ) niet onverwacht. In lab experimenten werd een voorkeur voor fijn $(<500 \mu \mathrm{m})$ (Gibson en Robb, 2000) of zeer fijn (<125 $\mu \mathrm{m})$ (Nasir en Poxton, 2001) zand aangetoond. Deze studies laten echter ook zien dat schol van een bredere range aan korrelgroottes gebruik maakt en zich in grover sediment kan ingraven.

De multivariate analyse liet zien dat er weinig verschil was in de samenstelling van de soortgemeenschappen als ze gescheiden werden op basis van gemiddelde korrelgrootte van het sediment. Dit is waarschijnlijk ook het gevolg van de relatieve homogeniteit in sedimentsamenstelling van de vooroever. De visgemeenschap in de slibrijkere Waddenzee week wel duidelijk af van die in de vooroever.

Om een beter beeld te krijgen van sedimentvoorkeuren van verschillende soorten (of verschillende leeftijdsklassen) bieden lab of mesocosmexperimenten een uitweg waarbij een veel grotere range aan sedimentsamenstellingen aangeboden kan worden. Dit is voor tong al succesvol uitgevoerd (Post e.a., 2017). Uit de studie van Tien e.a. (2017) zijn ook sedimentpreferenties van de verschillende soorten zandspiering beschikbaar, die nu verder in het lab onderzocht worden (Ole Hendriksen, DTU aqua).

Aan de hand van de strandbemonsteringen in 2019 en 2020 kon de groei door het seizoen gevolgd worden. Hieruit bleken geen grote verschillen tussen de bemonsterde gebieden en leken overal de maximale groeisnelheden behaald te worden voor de heersende watertemperaturen (Texel, Castricum en Katwijk in 2019 en IJmuiden en Egmond in 2020), oftewel voedselaanbod en competitie was waarschijnlijk niet beperkend. In een studentonderwerp is de RNA:DNA-methode (Ciotti e.a., 2013a) gebruikt om de groei van platvis in de vier kustvakken te onderzoeken (Rutting, 2017). Hieruit bleken wel gebiedsverschillen op te treden tussen de vier kustvakken in RNA:DNA-ratio's van schar maar niet van schol en tong. De verschillen in schar konden echter niet een op een gerelateerd worden aan gebiedsverschillen (of sedimentsamenstelling) omdat de survey van zuid naar noord was uitgevoerd. Dus afgezien van een gebiedsverschil was er ook een temporeel verschil tussen de vakken.

Op basis van DNA-barcoding is het dieet van jonge platvis langs de kust geanalyseerd in twee studentonderwerpen (van Berkel, 2020; Meppelink, 2021). Uit de eerste analyses bleek dat het dieet tussen de bemonsterde gebieden langs de kust varieerde: langs de Noord-Hollandse kust werden naar verhouding meer wormen gegeten. De meest voorkomende soorten in alle gebieden behoorden tot de geleedpotigen. Veel voorkomende prooisoorten waren eenoogkreeftjes (Harpacticus flexus), zeekomma's (Monopseudocuma gilsoni), driepuntsgarnaaltje (Philocheras trispinosus), aasgarnalen (Schistomysis ornata) en Noordelijke zandkokerworm (Spiophanes bombyx). Er was een verband 
tussen visgrootte en dieet: de grotere individuen aten naar verhouding meer mollusken en geleedpotigen.

In Herman e.a. (2021) wordt aangegeven dat als door suppleties vergroving van het fijne sediment optreedt dit met name in de diepere zone $(>6 \mathrm{~m}$ ) tot een verandering in benthisch gemeenschappen kan leiden. Echter ecologische gevolgen voor de rest van het voedselweb, kan uit die studie niet worden afgeleid.

Een groot deel van de prooisoorten van schol werden niet aangetroffen in de benthosmonsters en ook de boomkorbemonstering is geen geschikte methode om deze te bemonsteren. Soorten uit de zoöplanktonbemonstering zijn helemaal niet aangetroffen in het dieet.

De verdiepende DNA-barcodingstudies zijn in de marge van het Natuurlijk Veilig programma uitgevoerd en waren primair gericht op methode-ontwikkeling. Om de resultaten hiervan echt goed te kunnen gebruiken zouden de methodes toegepast moeten worden op een grotere set monsters zodat ook statistisch verantwoorden uitspraken gedaan kunnen worden.

\subsubsection{Toekomstig functioneren: klimaatverandering (in combinatie met suppleties)}

Vergeleken met de Eems-Dollard en Waddenzee vindt opwarming in de kustzone door klimaatverandering minder snel plaats, maar ook in de kustzone zal de komende decennia de watertemperatuur gaan stijgen. Klimaatverandering kan voor verschillende soorten afhankelijk van hun temperatuurtolerantie verschillend uitpakken. Tot het moment van de optimale temperatuur voor groei is bereikt werkt opwarming positief, bij temperaturen die hoger liggen dan het optimum is de uitwerking negatief. Voor tong is de opwarming op basis van de gebruikte klimaatscenario's voor 2050 in alle gevallen gunstig terwijl dat voor schol in een aantal gevallen de groei negatief beïnvloedt. Door hogere temperaturen groeit tong sneller en is groter aan het eind van het groeiseizoen. De modelberekening liet zien dat temperatuurstijging gedurende jaren die normaal koud zouden zijn de groei van schol positief beïnvloedt, terwijl in jaren die normaal gesproken al warm zouden zijn, de temperatuurstijging tot zeer ongunstige groeiomstandigheden leidt voor schol. In dieper water is het effect op de groei naar verwachting gemiddeld positief. Voor andere soorten zal het effect van temperatuurstijging verschillen afhankelijk van hun temperatuurvoorkeuren. Die temperatuurvoorkeur is, naast dat deze soortspecifiek is, ook afhankelijk van de grootte (leeftijd) van de vis: hoe groter hoe lager hun tolerantieniveau (Figuur 8.1). De voorspelde temperatuurstijging zal voor soorten met een relatief laag tolerantieniveau (schol, maar ook haring) maar ook voor grote(re) vis in ondiepe kustwateren naar verwachting negatief uitpakken, terwijl voor soorten met een relatief hoog tolerantieniveau (tong, maar ook ansjovis en pelser) een positief effect verwacht kan worden. Voor schol worden met name in de Schelde en Waddenzee zeer ongunstige groeiomstandigheden voorspeld, hierdoor zal het functioneren van deze gebieden als kinderkamer voor schol afnemen. De kustzone lijkt minder beïnvloed te worden door temperatuurstijging en voor de diepere wateren lijkt er zelfs een positief effect op de groei van schol te zijn. Dit zou kunnen betekenen dat het functioneren van de kustzone als opgroeigebied voor schol in verhouding tot de Waddenzee toe zal nemen, en dat ook het belang van de kustzone voor de Noordzeepopulatie toeneemt.

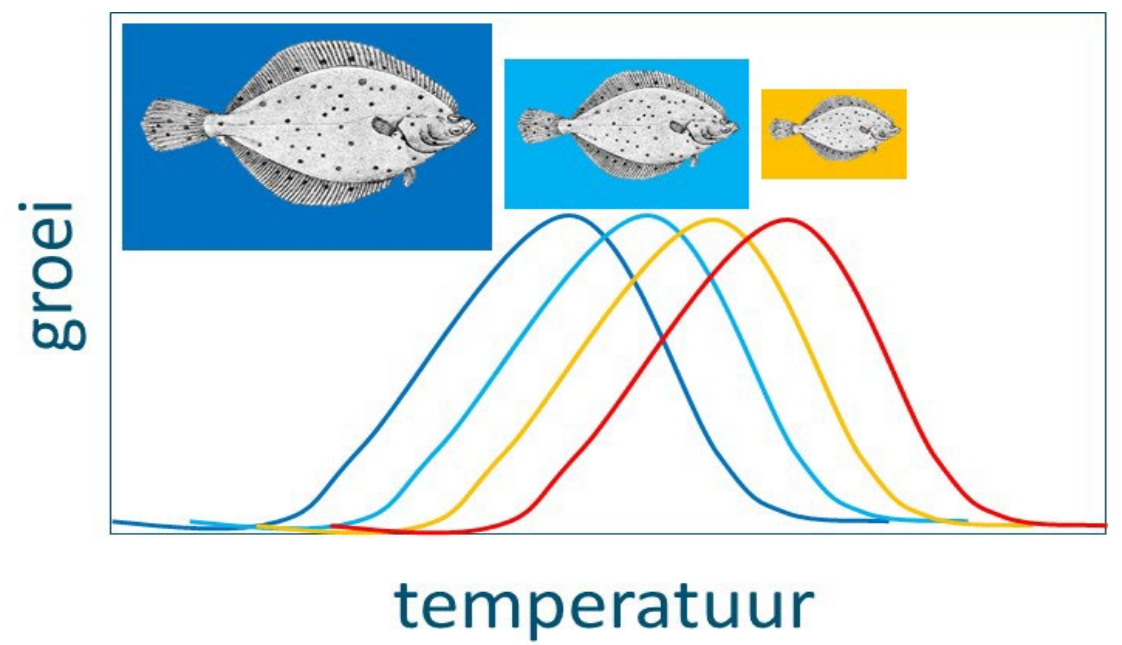

Figuur 8.1 Relatie tussen temperatuur en tolerantie van vissen van verschillende grootte. 


\subsection{Relatie zandsuppleties en kinderkamerfunctie}

Zandsuppleties in de vooroever hebben als directe impact het bedelven van de organismen, waaronder mogelijk ook ingegraven vis die niet op tijd kan vluchten. Gezien de beperkte schaal waarop suppleties op dit moment plaatsvinden vergeleken met de totaaloppervlakte van de vooroever heeft dit geen gevolgen voor vispopulaties die deels afhankelijk zijn van de vooroever. Er zijn geen vissoorten aangetroffen waarvoor je specifieke gebieden in de vooroever zou moeten vermijden. Daarbij komt dat in de meeste studies kort na een suppletie al snel de verwachte visgemeenschap aangetroffen werd (Holzhauer e.a., 2014; Colson e.a., 2016; van Hal e.a., 2021), al is dit geen garantie dat de habitatkwaliteit niet veranderd is.

Op de langere termijn kunnen de effecten van zandsuppleties echter op verschillende manieren doorwerken op de kinderkamers van de Nederlandse kustzone. Zowel de sedimentsamenstelling, de vorm van het kustprofiel als de dynamiek in het kustgebied kunnen beïnvloed worden. Een verandering in de morfologie kan leiden tot veranderingen in de temperatuur (ondiep water warmt sneller op), en een veranderde habitatkwaliteit kan gevolgen hebben voor benthische soorten en daarmee de voedselkwantiteit en -samenstelling voor juveniele vis.

Uit Herman e.a. (2021) blijkt dat gesteld kan worden dat zowel natuurlijke processen als het suppleren een impact hebben op de sedimentsamenstelling van de kust. Een langetermijnverandering van de bodemsamenstelling kon echter niet worden vastgesteld met de beschikbare data. Lokaal kan de sedimentsamenstelling bij grootschalige suppleties en/of havendammen veranderen, en kunnen gebieden met grover of fijner sediment ontstaan. Metingen van de sedimentsamenstelling bij vooroeversuppleties zijn echter niet beschikbaar, waardoor het lokale effect daarvan niet kon worden ingeschat. Pas als er langdurig en structureel met grover sediment wordt gesuppleerd kan de bodemsamenstelling van het hele kustsysteem veranderen. Als gevolg van vergroving van het sediment door suppleties zal het kustprofiel (een beetje) steiler worden, doordat meer sediment in ondiep water zal blijven 'hangen'. De vorm van het kustprofiel (steilheid) kan van belang zijn voor soorten die een duidelijke voorkeur voor bepaalde dieptes hebben (tarbot, griet, grondel en zandspiering). Hierdoor kan de oppervlakte van een bepaalde dieptezone veranderen en daarmee de oppervlakte dat gebruikt kan worden als kinderkamer.

Onze studie bevestigt dat het sediment langs de Nederlandse kust voornamelijk bestaat uit fijn zand. Slibrijk en grover zand is zeer beperkt aangetroffen. De variatie in korrelgrootte heeft voor de verspreiding van schol geen doorslaggevende rol. Voor tong, grondel en zandspiering is de sedimentsamenstelling wel een bepalende factor en voor tong lijkt met name slibgehalte bepalend te zijn. Aangezien veel benthossoorten een sterke relatie vertonen met sediment en bodemschuifspanning zijn effecten op benthos en doorwerking daarvan op vis voorstelbaar. Deze relatie is in deze onderzoeksfase nog niet goed uitgezocht.

Uit de strandbemonsteringen komt naar voren dat de visdichtheden op relatief beperkte ruimtelijke schaal variëren. In de geulen worden andere soorten of dichtheden gevangen dan in trekken direct langs het strand. Ook komen er indicaties uit deze bemonsteringen dat de aanwezigheid van banken of andere oneffenheden direct effect hebben op de aanwezigheid van vis. In 2019 bij Castricum werden ineens tarbotten gevangen toen er na een storm een verondieping in het transect langs de kust was ontstaan. Het lijkt er dus op dat een dynamisch systeem gunstig is voor de biodiversiteit en mogelijke enkele soorten in het bijzonder.

\subsection{Aanbevelingen voor het inrichten van suppleties}

$\mathrm{Er}$ is geconstateerd dat er aan de hand van de huidige gegevens geen duidelijke hotspots of cruciale locaties voor demersale vis aanwezig zijn in de vooroever van de Nederlandse kust. De meeste soorten lijken de gehele of op zijn minst een uitgebreid deel van de vooroever te gebruiken. Ten tweede lijken suppleties van de huidige omvang in de dynamische vooroever alleen lokaal en korte termijneffecten te hebben op de aanwezigheid van vis (Holzhauer e.a., 2014; Colson e.a., 2016; van Hal e.a., 2021). 


\section{Aanbevelingen bij de huidige suppletievolumes}

Het voortzetten van de huidige manier van suppleren heeft hoogstwaarschijnlijk geen gevolgen voor de populatieomvang van de vissoorten die gebruik maken van de vooroever, maar leidt wel tot mortaliteit op de locatie van suppleren als gevolg van het begraven van demersale vissen. Op basis van het uitgevoerde onderzoek hebben we een aantal aanbevelingen om deze mortaliteit te verminderen:.

- $\quad$ Een mitigerende maatregel om directe sterfte te reduceren is om geen suppleties uit te voeren in de periode waarin vislarven aankomen en waarin de juvenielen opgroeien in ondiep water. De exacte periode verschilt per soort, maar de beste periode om te suppleren uit visoogpunt zou zijn oktober tot maart.

- Juveniele vis groeit op in de ondiepe kustzee. Vanuit het oogpunt van reductie van directe mortaliteit van vis door begraving zijn strandsuppleties te prefereren boven vooroeversuppleties.

- $\quad$ Bij vooroeversuppleties kunnen andere technieken voor suppleren in plaats van rainbowen of klappen leiden tot een verminderde begraving van vis. Een methode waarbij het gesuppleerde zand over een groter gebied wordt verspreid (en dus in een minder grote laagdikte ineens) zal sterfte door begraving verminderen.

- Om te voorkomen dat suppleties leiden tot vergroving van sediment is het aan te bevelen om zand te winnen dat zo dicht mogelijk de samenstelling van het sediment in het te suppleren gebied benadert (of nog iets fijner is).

- Meer speculatief: inzetten van methodes om vis te verjagen alvorens de suppletieactiviteiten uit te voeren. Welke methodes dat zouden kunnen zijn en of dit haalbaar en uitvoerbaar is, is nu lastig te zeggen.

Daarnaast zou om de habitatkwaliteit voor tong in de vooroever te verbeteren overwogen kunnen worden slibrijkere gebieden te creëren. Er vindt al aanvoer van slib langs de kust plaats en accumulatie hiervan wordt voorkomen door de dynamiek in de ondiepe kustzone. Wanneer slib actief wordt aangebracht moet ervoor gezorgd worden dat de dynamiek ter plaatse niet verhindert dat het slib blijft liggen. Daarnaast zou suppleren met slibrijk sediment kunnen zorgen voor extra vertroebeling met mogelijke gevolgen voor andere soorten. De verwachting van extra vertroebeling door (reguliere) suppleties wordt in de dynamische vooroever beschouwt als beperkt, lokaal en van korte duur (Herman e.a., 2016).

\section{Aanbevelingen bij toekomstige grotere volumes}

Bij toekomstige grotere suppletievolumes kan het ontwikkelen van een gevarieerde (en dynamische) brandingszone onderdeel zijn van een suppletiestrategie. Een mogelijkheid zou zijn om de variatie in het gebied te vergroten door het creëren van langgerekte banken, geulen en luwten, passend bij de natuurlijke morfologische dynamiek en aansluitend op natuurlijke kustfenomenen als slufters en groene stranden. Verondiepen van bestaande bankstructuren en mogelijk zelfs (tijdelijk) droog te leggen kan voor vis positief uitwerken. Op deze wijze kunnen langgerekte eilanden ontstaan parallel aan de huidige kust. Feitelijk wordt hiermee de strandlengte en dus ook het oppervlak ondiepe kustzone verdrievoudigd. Naast de eilanden ontstaan ondieptes en luwten en wanneer de eilanden langzaam afkalven ontstaan er gradiënten in ondieptes. Dit verhoogt de variatie in microhabitats wat bevorderlijk kan zijn voor juveniele vis en ook andere soorten dan er nu vooral voorkomen

\section{Aanbevelingen in relatie tot klimaatverandering}

Onder invloed van klimaatverandering zal de habitatkwaliteit van de vooroever veranderen voor de verschillende soorten. Enkele van de huidige soorten zoals schol kunnen het bij verder stijgende watertemperaturen lastig krijgen en zullen in dominantie afnemen. Terwijl soorten die een voorkeur hebben voor warmer water, zoals tong maar ook de pelagische soorten zeebaars en harder, op termijn naar verwachting dominanter zullen worden in de vooroever. Het is daarom aan te bevelen om bij het aanleggen van de suppleties met name ook te kijken naar de habitateisen van deze soorten. 


\subsection{Aanbevelingen voor vervolgonderzoek}

Natuurlijk Veilig heeft voor het eerst sinds midden jaren 1980 weer een beeld gegeven van de kustzone in het voorjaar. Bij het interpreteren van de gegevens blijkt duidelijk het gemis van gegevens van de recentere periode in het voorjaar, en eigenlijk over seizoensdynamiek gedurende het hele jaar. Hierdoor hebben we geen zicht op verschuivingen in de aankomst van soorten, gebruik van de verschillende dieptes en het aantalsverloop over een jaar. Er is uitsluitend een beeld over de ondiepe vooroever aan het einde van het groeiseizoen, alle variatie en omgevingsvariabelen die daartoe hebben geleid zijn grotendeels onbekend. Het voortzetten van een voorjaarsbemonstering of zelfs een bemonstering door het gehele jaar heen zou hier inzicht in kunnen geven. Deze bemonstering zou zich niet moeten beperken tot de soorten geanalyseerd in deze studie, maar inzicht proberen te geven in de gehele visgemeenschap van de vooroever.

Vanaf het strand van IJmuiden heeft WMR, op vrijwillige basis, vorig jaar en in het lopende jaar een vervolg op zeer beperkte schaal gegeven. Deze bemonsteringen hebben al veel inzichten en nuttige data opgeleverd, maar hebben ook geleid tot meer vragen over de aankomst van de verschillende soorten en het gebruik van de vooroever op een kleine ruimtelijke schaal. Voortzetting van deze bemonsteringen verdient aanbeveling, omdat dit op een kosteneffectieve manier een beeld geeft van de variatie in tijd (en ruimte wanneer meer plekken meegenomen worden) van juveniele vis.

Het belang van de kinderkamergebieden voor de volwassen populatie wordt nu vooral bepaald op basis van de hoeveelheid juveniele vis die op een bepaald moment aanwezig is in het gebied, zoals gedaan in van Beek e.a. (1989). Deze dichtheden zeggen echter niet meteen iets over de werkelijke bijdrage aan de volwassenpopulatie. Gebruikmakend van verschillende technieken, zoals microchemische analyse van de otolieten waarbij op basis van de chemische samenstelling van de verschillende lagen in de otoliet kan worden vastgesteld in welke gebied ze zijn geweest, is het mogelijk om voor de volwassenvissen af te leiden uit welke kinderkamer ze afkomstig zijn. Op die manier kan de bijdrage van de verschillende kinderkamergebieden vergeleken worden.

Visbemonsteringen laten meestal een grote variatie in vangsten zien. Dat is in de vooroever wellicht nog sterker het geval dan in dieper water. Er is echter maar zeer beperkt kennis over de oorzaken voor deze variatie. In de ondiepe vooroever lijken de aanwezigheid van geulen, muien en poeltjes (kleinschalige habitats) een deel van deze variatie te kunnen verklaren. Mogelijk geldt dit ook voor andere structuren zoals de strandhoofden en kunstwerken in de havenmondingen, waarover in de Nederlandse vooroever nagenoeg geen kennis aanwezig is. Het een vervolgonderzoek zou hier meer aandacht aan kunnen besteden: hebben dit soort structuren een belangrijke functie en voor welke soorten?

Een belangrijk oorzaak voor de variatie in visdichtheden voor een gebied, is hoogstwaarschijnlijk de aanwezigheid van prooisoorten en de afwezigheid van predatoren. Uitbreiding van kennis over de voedselweb-relaties met name in de vooroever zou de link tussen bodemfauna en vis kunnen verduidelijken. De studentenonderzoeken die op basis van DNA de dieetsamenstelling analyseerden waren vooral gericht op het ontwikkelen van de methode. Toepassing van deze methodes zouden inzicht kunnen geven in dieet en groei op grotere schaal.

Een deel van het huidige onderzoek was er opgericht om de huidige vooroever te vergelijken met de situatie in de periode voor de eerste suppleties. Een duidelijk hiaat blijkt de beschikbaarheid van sedimentgegevens uit de eerdere periodes Herman e.a. (2021). Dat hiaat kan natuurlijk niet meer opgevuld worden. Natuur Veilig en de KG 2.0. bemonsteringen in het Amelanderzeegat waren een van de eerste bemonsteringen waar naast visgegevens ook gegevens over het sediment verzameld werden. Het ontbreken van een relatie tussen sediment en het voorkomen van de meeste vissoorten houdt wellicht verband met de lage variatie in sedimentsamenstelling in de bemonsteringen. Voor de kustzone zou het uitbreiden van de WOT-schelpdiersurvey en de vissurveys met het verzamelen van sedimentmonsters van toegevoegde waarde kunnen zijn. Dan kunnen gegevens over de lokale sedimentsamenstelling gebruikt worden voor een beter begrip van de vissamenstelling. Relaties tussen vis en sedimentvoorkeuren in het veld kunnen dan wellicht over een grotere range aan 
korrelgroottes gelegd worden. Het uitvoeren van lab/mesocosm experimenten om de voorkeur van verschillende soorten en groottes beter uit te zoeken zou daarop een waardevolle aanvulling zijn.

De akoestische opnames en de gegevens uit de strandbemonsteringen hebben enig zicht gegeven op de aanwezigheid van pelagische vis in de vooroever. Voor zover wij weten waren dit de eerste bemonsteringen van pelagische vis in de ondiepe kustzone. Zonder pelagische vangsten was het niet mogelijk om de akoestische opnames te interpreteren. Meer inzicht in de aanwezigheid van de pelagische vis in de dit gebied is ecologisch uitermate relevant omdat pelagische vis belangrijk voedsel is voor zeevogels, zeehonden en bruinvis in de kustzone. Het voorkomen van pelagische vis bepaalt waarschijnlijk voor een groot deel de verspreiding van zeevogels en zeezoogdieren. Daarnaast heeft de strandbemonstering laten zien dat het gebied gebruikt wordt door juveniele zeebaarzen en (goud)harders. Dit zijn soorten die in de reguliere visbemonsteringen nagenoeg niet gevangen worden en waarover, met name wat betreft de juvenielen, zeer beperkte kennis is. De hoge aantallen die gevangen zijn in de branding bij IJmuiden maar ook bij Egmond aan Zee suggereren dat de brandingszone en mogelijk de ondiepe kustzone ook voor deze soorten een kinderkamerfunctie heeft en dat er mogelijk in de nabijheid van de kust ook gepaaid wordt door zeebaars (Tulp e.a., 2016b).

In de aanbeveling wordt genoemd technieken in te zetten om vis te verjagen voordat gestart wordt met de suppletieactiviteiten. In theorie zou dit voor mobiele soorten uiteraard mogelijk moeten zijn, er is echter weinig bekend over dit soort mogelijkheden. Er is bekend dat vissen reageren op antropogeen geluid, en ingegraven vis zou mogelijk ook kunnen worden verjaagd door beperkte verstoring van de bodem. Het is echter niet bekend of dit vluchtgedrag voldoende is om vissen uit een gebied ter grote van een suppletie te verjagen en waarschijnlijk keren vissen al kort na de inzet van dit soort technieken terug naar het gebied. Ondanks dat is vervolgonderzoek hieraan aan te bevelen. Een andere mogelijke techniek zou het inzetten van chemische signalen, bijvoorbeeld stoffen afgescheiden door predatoren, kunnen zijn. De detectie van deze stoffen zouden kunnen resulteren in het verlaten en vermijden van het gebied. Er is onderzoek gedaan naar de impact van dit soort chemische signalen op het gedrag, maar niet op het inzetten van dit soort stoffen in de context zoals hier bedoeld. 


\section{$9 \quad$ Kwaliteitsborging}

Wageningen Marine Research beschikt over een ISO 9001:2015 gecertificeerd kwaliteitsmanagementsysteem. Dit certificaat is geldig tot 15 december 2021. De organisatie is gecertificeerd sinds 27 februari 2001. De certificering is uitgevoerd door DNV GL. 


\section{Dankwoord}

Onze dank gaat uit naar alle vrijwilligers die hebben meegeholpen tijdens de verschillende strandbemonstering in de afgelopen jaren. De WMR-collega's die in hun vrije tijd meekwamen helpen op het strand, maar zeker ook de vrijwilligers van de strandwerkgroep en van NJN. Speciale dank gaat hierbij uit naar Dennis Leeuw, die niet alleen tijdens de eerste strandbemonsteringen bij Castricum enthousiast en veelvuldig heeft geholpen, maar daarna ook eigenhandig de bemonstering bij Egmond aan Zee heeft voortgezet met een groep vrijwilligers.

Verder willen we de collega's van Deltares, Theo Prins en Peter Herman bedanken voor hun inbreng in de verschillende discussies tijdens het project, deze hebben zeer zeker bijgedragen aan de totstandkoming van deze rapportage. Ook de bijdrages van het uit het convenant-team, waaronder die van de RWS-opdrachtgevers hebben bijgedragen aan de totstandkoming van deze rapportage. 


\section{Literatuur}

Aarts, G., S. Brasseur, J. J. Poos, J. Schop, R. Kirkwood, T. van Kooten, E. Mul, P. Reijnders, A. D. Rijnsdorp en I. Tulp (2019) Top-down pressure on a coastal ecosystem by harbor seals. Ecosphere 10: e02538.

Amara, R., P. Laffargue, J. Dewarumez, C. Maryniak, F. Lagardère en C. Luzac (2001) Feeding ecology and growth of O-group flatfish (sole, dab and plaice) on a nursery ground (Southern Bight of the North Sea). Journal of Fish Biology 58: 788-803.

Aneer, G. en L. Westin (1990) Migration of turbot (Psetta maxima L.) in the northern Baltic proper. Fisheries Research 9: 307-315.

Baptist, M., L. Bolle, B. Couperus, I. Tulp en R. v. Hal (2017) Ecologisch Gericht Suppleren: meetplan geïntegreerde ecosysteem survey 2017. Wageningen Marine Research.

Barbut, L., C. Groot Crego, S. Delerue-Ricard, S. Vandamme, F. A. M. Volckaert en G. Lacroix (2019) How larval traits of six flatfish species impact connectivity. Limnology and Oceanography 64: 1150-1171.

Berghahn, R. (1983) Untersuchungen an Plattfischen und Nordseegarnelen (Crangon crangon) im Eulitoral des Wattenmeeres nach dem Ubergang zum bodenleben. Helgoländes Meeresuntersuchungen 36: 163-181.

Bergman, M. J. N., H. W. van der Veer en J. J. Zulstra (1988) Plaice nurseries: effects on recruitment. Journal of Fish Biology 33: 201-218.

Beyst, B., A. Cattrijsse en J. Mees (1999) Feeding ecology of juvenile flatfishes of the surf zone of a sandy beach. Journal of Fish Biology 55: 1171-1186.

Beyst, B., K. Hostens en J. Mees (2001) Factors influencing fish and macrocrustacean communities in the surf zone of sandy beaches in Belgium: Temporal variation. Journal of Sea Research 46: 281-294.

Beyst, B., K. Hostens en J. Mees (2002) Factors influencing the spatial variation in fish and macrocrustacean communities in the surf zone of sandy beaches in Belgium. Journal of the Marine Biological Association of the United Kingdom 82: 181-187.

Birchenough, S. N., H. Reiss, S. Degraer, N. Mieszkowska, Á. Borja, L. Buhl-Mortensen, U. Braeckman, J. Craeymeersch, I. De Mesel en F. Kerckhof (2015) Climate change and marine benthos: a review of existing research and future directions in the North Atlantic. Wiley interdisciplinary reviews: climate change 6: 203-223.

Bolle, L. J., M. D. C. Dickey-Collas, P. Erftemeijer, van Beek J. K. L., H. M. Jansen, J. Asjes, A. D. Rijnsdorp en H. J. Los (2005) Transport of fish larvae in the Southern North Sea. Netherlands Institute for Fisheries Research.

Bolle, L. J., M. Dickey-Collas, J. K. L. van Beek, P. L. A. Erftemeijer, J. I. J. Witte, H. W. van der Veer en A. D. Rijnsdorp (2009) Variability in transport of fish eggs and larvae. III. Effects of hydrodynamics and larval behaviour on recruitment in plaice. Marine Ecology Progress Series 390: 195-211.

Burrows, M. T. (2001) Depth selection behaviour during activity cycles of juvenile plaice on a simulated beach slope. Journal of Fish Biology 59: 116-125.

Champalbert, G., C. Macquart-Moulin en B. Howell (1992) Influence of sediment on the settlement of larvae and juvenile sole,(Solea solea I) in laboratory conditions. Marine \& Freshwater Behaviour \& Phy 21: 255-276.

Ciotti, B. J., T. E. Targett en M. T. Burrows (2013a) Spatial variation in growth rate of early juvenile European plaice Pleuronectes platessa. Marine Ecology Progress Series 475: 213-232.

Ciotti, B. J., T. E. Targett, R. D. M. Nash en M. T. Burrows (2013b) Small-scale spatial and temporal heterogeneity in growth and condition of juvenile fish on sandy beaches. Journal of Experimental Marine Biology and Ecology 448: 346-359.

Ciotti, B. J., T. E. Targett, R. D. M. Nash en A. J. Geffen (2014) Growth dynamics of European plaice Pleuronectes platessa L. in nursery areas: A review. Journal of Sea Research 90: 64-82.

Colson, L., E. Pecceu, M. Steenkamer, J. Wittoeck, C. van Colen, K. Hostens en G. Van Hoey (2016) Ecologische monitoring strand-en vooroever in functie van suppletie activiteiten.

Couperus, B., S. Gastauer, S. M. M. Fässler, I. Tulp, H. W. van der Veer en J. J. Poos (2016) Abundance and tidal behaviour of pelagic fish in the gateway to the Wadden Sea. Journal of Sea Research 109: 4251.

Couperus, B., M. Baptist, D. Burggraaf, A. Dijkman-Dulkes, J. Perdon, M. Post en H. Verdaat (2017) Ecologisch gericht suppleren : verslag pilot multi-method survey 2016. Wageningen Marine Research.

Couperus, B., S. Sakinan en D. Burggraaf (2020) Small pelagic fish and zooplankton in the Dutch coastal surf zone during the EGS-II survey in 2017-2018. Wageningen Marine Research. 
Cronin, K., T. Van der Kaaij, J. Dijkstra, J. Van Beek, R. Plieger en M. Blaas (2013) Setup and evaluation of baseline hydrodynamic and SPM models: MoS2-III: model-supported monitoring of SPM in the Southern North Sea. Deltares report 1208242.

Damsma, P., H. Holzhauer, T. Vermaas, B. van de Valk, L. van Duren en A. de Backer (2017) Ecologisch gericht suppleren I, resultaten van het onderzoek.

Dapper, R. (1978) De Balgzand scholgegevens 1975, 1976, 1977. NIOZ, 53 pagina's.

de Boois, I. J., R. A. Bol en R. Verkempynck (2018) Reisverslag BTS 2018. Wageningen Marine Research, Research rapport 18.011.

de Raedemaecker, F. (2012) Defining habitat characteristics influencing the distribution, density and growth of Plaice (Pleuronectes platessa) and Dab (Limanda limanda) on West of Ireland nursery grounds. Unpublished thesis thesis, Galway-Mayo Institute of Technology, Galway, Ireland.

De Veen, J. F. (1978) On selective tidal transport in the migration of North Sea plaice (Pleuronectes platessa L.) and other flatfish species. Netherlands Journal of Sea Research 12: 115-147.

De Vlas, J. (1979) Annual food intake by plaice and flounder in a tidal flat area in the dutch wadden sea, with special reference to consumption of regenerating parts of macrobenthic prey. Netherlands Journal of Sea Research 13: 117-153.

de Vries, J. (1974) Groei en konditie van jonge schol in Noord-en Waddenzee, en onder laboratoriumomstandigheden. NIOZ-RAPPORT.

Dieterich, C., S. Wang, S. Schimanke, M. Gröger, B. Klein, R. Hordoir, P. Samuelsson, Y. Liu, L. Axell en A. Höglund (2019) Surface heat budget over the North Sea in climate change simulations. Atmosphere 10: 272.

Eastwood, P. D., G. J. Meaden, A. Carpentier en S. I. Rogers (2003) Estimating limits to the spatial extent and suitability of sole (Solea solea) nursery grounds in the Dover Strait. Journal of Sea Research 50: 151-165.

Edwards, R. en J. H. Steele (1968) The ecology of 0-group plaice and common dabs at Loch Ewe I. Population and food. Journal of Experimental Marine Biology and Ecology 2: 215-238.

Ellis, T. en R. N. Gibson (1995) Size-selective predation of 0-group flatfishes on a Scottish coastal nursery ground. Marine Ecology Progress Series 127: 27-37.

Engelhard, G. H., J. K. Pinnegar, L. T. Kell en A. D. Rijnsdorp (2011) Nine decades of North Sea sole and plaice distribution. ICES Journal of Marine Science 68: 1090-1104.

Florin, A.-B. en F. Franzén (2010) Spawning site fidelity in Baltic Sea turbot (Psetta maxima). Fisheries Research 102: 207-213.

Florin, A. B. en G. Lavados (2010) Feeding habits of juvenile flatfish in relation to habitat characteristics in the Baltic Sea. Estuarine Coastal and Shelf Science 86: 607-612.

Fonds, M. (1973) Sand gobies in the Dutch Wadden Sea (pomatoschistus, gobiidae, pisces). Netherlands Journal of Sea Research 6: 417-478.

Fonds, M. (1978) The seasonal distribution of some fish species in the Western Dutch. Wadden Sea. Fishes and Fisheries of the Wadden.

Freitas, V., J. F. M. F. Cardoso, K. Lika, M. A. Peck, J. Campos, S. A. L. M. Kooijman en H. W. van der Veer (2010) Temperature tolerance and energetics: a dynamic energy budget-based comparison of North Atlantic marine species. Philosophical Transactions of the Royal Society of London B: Biological Sciences 365: 3553-3565.

Freitas, V., J. I. J. Witte, I. Tulp en H. W. van der Veer (2016) Shifts in nursery habitat utilization by 0-group plaice in the western Dutch Wadden Sea. Journal of Sea Research 111: 65-75.

Gibson, R. N. (1973) The intertidal movements and distribution of young fish on a sandy beach with special reference to the plaice (Pleuronectes platessa L.). Journal of Experimental Marine Biology and Ecology 12: 79-102.

Gibson, R. N. (1994) Impact of habitat quality on the recruitment of juvenile flatfishes. Netherlands Journal of Sea Research 32: 191-206.

Gibson, R. N., M. C. Yin en L. Robb (1995) The Behavioural Basis of Predator-Prey Size Relationships Between Shrimp (Crangon Crangon) and Juvenile Plaice (Pleuronectes Platessa). Journal of the Marine Biological Association of the United Kingdom 75: 337-349.

Gibson, R. N., L. Pihl, M. T. Burrows, J. Modin, H. Wennhage en L. A. Nickell (1998) Diel movements of juvenile plaice Pleuronectes platessa in relation to predators, competitors, food availability and abiotic factors on a microtidal nursery ground. Marine Ecology Progress Series 165: 145-159.

Gibson, R. N. en L. Robb (2000) Sediment selection in juvenile plaice and its behavioural basis. Journal of Fish Biology 56: 1258-1275.

Gibson, R. N., M. T. Burrows en L. Robb (2011) Field experiments on depth selection by juvenile plaice Pleuronectes platessa. Marine Ecology Progress Series 430: 197-206.

Glorius, S. T., K. E. v. d. Wolfshaar en I. Tulp (2012) Abundance patterns of six fish species in the shallow coastal zone in The Netherlands. Report / IMARES Wageningen UR ; C101/12. IJmuiden [etc.], IMARES Wageningen UR. 
Guillén, J. en P. Hoekstra (1997) Sediment distribution in the nearshore zone: grain size evolution in response to shoreface nourishment (Island of Terschelling, The Netherlands). Estuarine, coastal and shelf science 45: 639-652.

Haynes, P., D. Brophy, F. De Raedemaecker en D. McGrath (2011) The feeding ecology of 0 year-group turbot Scophthalmus maximus and brill Scophthalmus rhombus on Irish west coast nursery grounds. Journal of Fish Biology 79: 1866-1882.

Haynes, P. S., D. Brophy, D. McGrath, R. O'Callaghan, S. Comerford en P. Casburn (2010) Annual and spatial variation in the abundance length and condition of juvenile turbot (Psetta maxima L.) on nursery grounds on the west coast of Ireland: 2000-2007. Journal of Sea Research 64: 494-504.

Haynes, P. S., D. Brophy en D. Mcgrath (2014) The timing of early life events and growth rate estimates of age-0 year group brill Scophthalmus rhombus along the west coast of Ireland. Journal of Fish Biology 84: 225-230.

Heessen, H. J. L., J. R. Ellis en N. Daan (2015) Fish Atlas Of The Celtic Sea, North Sea, And Baltic Sea, KNNV uitgeverij.

Heindler, F. M., G. E. Maes, S. Delerue-Ricard, A. Vanden Bavière, K. Hostens en F. A. M. Volckaert (2019) Diet composition and gut microbiome of 0-group European plaice Pleuronectes platessa L. - Strong homogeneity and subtle spatial and temporal differences. Journal of Sea Research 144: 67-77.

Herman, P., H. Meijer-Holzhauer, S. Vergouwen, J. Wijsman en M. J. Baptist (2016) Ecologische effecten van kustsuppleties; Systeembeschrijving (deel A), onderzoeksprioriteiten (deel B) en ontwerp uitvoeringsplan (deel C). Deltares, 100 pagina's.

Herman, P., B. J. A. Huisman en T. Prins (2021) Natuurlijk Veilig; Cumulatief effect van zandsuppleties op sediment en bodemdieren. Deltares, 82 pagina's.

Hiddink, J. G., M. T. Burrows en J. García Molinos (2015) Temperature tracking by North Sea benthic invertebrates in response to climate change. Global Change Biology 21: 117-129.

Höffle, H., C. J. Van Damme, C. Fox, S. Lelièvre, C. Loots, R. D. Nash, S. Vaz, P. J. Wright en P. Munk (2018) Linking spawning ground extent to environmental factors-patterns and dispersal during the egg phase of four North Sea fishes. Canadian journal of fisheries and aquatic sciences 75: 357-374.

Holzhauer, H., B. Van der Valk, J. van Dalfsen, M. Baptist en G. Janssen (2009) Ecologisch gericht suppleren, nu en in de toekomst: Het ontwerp meerjarenplan voor monitoring en (toepassingsgericht) onderzoek. Deltares.

Holzhauer, H., T. Vanagt, K. Lock, C. van Oeveren, A. De Backer, K. Hostens, J. van Dalfsen en J. Reinders (2014) Ecologische effecten suppletie Ameland 2009-2012.

Holzhauer, H., B. W. Borsje, J. A. Van Dalfsen, K. M. Wijnberg, S. J. Hulscher en P. M. Herman (2020) Benthic species distribution linked to morphological features of a barred coast. Journal of marine science and engineering 8: 16.

Huisman, B., E. Sirks, L. Van der Valk en D. Walstra (2014) Time and spatial variability of sediment grading in the surfzone of a large scale nourishment. Journal of Coastal Research: 127-132.

Hunt, B. en T. Elliott (2004) Interaction of climatic variability with climatic change. Atmosphere-Ocean 42: 145-172.

ICES (2020) Working Group on Beam Trawl Surveys (WGBEAM; outputs from 2019 meeting), 104 pagina's.

ICES (2021) Plaice (Pleuronectes platessa) in Subarea 4 (North Sea) and Subdivision 20 (Skagerrak); ICES Advice on fishing opportunities, catch, and effort Greater North Sea ecoregionin ICES, ed. Copenhagen.

Iles, T. en R. Beverton (1991) Mortality rates of 0-group plaice (Pleuronectes platessa L.), dab (Limanda limanda L.) and turbot (Scophthalmus maximus L.) in European waters: I. Statistical analysis of the data and estimation of parameters. Netherlands Journal of Sea Research 27: 217-235.

IPCC (2019) Summary for Policymakers. In: IPCC Special Report on the Ocean and Cryosphere in a Changing Climate.

Jager, Z., H. L. Kleef en P. Tydeman (1993) The distribution of 0-group flatfish in relation to abiotic factors on the tidal flats in the brackish Dollard (Ems Estuary, Wadden Sea). Journal of Fish Biology 43: 3143.

Jager, Z., H. L. Kleef en P. Tydeman (1995) Mortality and growth of 0-group flatfish in the brackish dollard (Ems Estuary, Wadden Sea). Netherlands Journal of Sea Research 34: 119-129.

Jager, Z. en H. Kleef (1999) Het functioneren van de Eems-Dollard als kinderkamer voor platvis: 3. Aantalsverloop en lengtetoename van juveniele schol, bot en tong in Dollard en Eems. Rapport RIKZ= Report RIKZ.

Janssen, G. en S. Mulder (2004) De ecologie van de zandige kust van Nederland: Inventarisatie van het marcobenthos van zand en brandingszone. Rapportnr.: 2004.033.

Janssen, G., H. Kleef, S. Mulder en P. Tydeman (2008) Pilot assessment of depth related distribution of macrofauna in surf zone along Dutch coast and its implications for coastal management. Marine Ecology 29: 186-194. 
Jones, A. (1973a) Observations on the growth of turbot larvae Scophthalmus maximus L. reared in the laboratory. Aquaculture 2: 149-155.

Jones, A. (1973b) The ecology of young turbot, Scophthalmus maximus (L.), at Borth, Cardiganshire, Wales. Journal of Fish Biology 5: 367-383.

Jones, A. (1974) Sexual maturity, fecundity and growth of the turbot Scophthalmus maximus L. Journal of the Marine Biological Association of the United Kingdom 54: 109-125.

Kerby, T. K., W. W. L. Cheung, C. van Oosterhout en G. H. Engelhard (2013) Entering uncharted waters: Long-term dynamics of two data limited fish species, turbot and brill, in the North Sea. Journal of Sea Research 84: 87-95.

Koutsikopoulos, C., Y. Desaunay, D. Dorel en J. Marchand (1989) The role of coastal areas in the life history of sole (Solea solea L.) in the Bay of Biscay. Scientia Marina (Barcelona).

Kuipers, B. (1975) On the efficiency of a two-metre beam trawl for juvenile plaice (Pleuronectes Platessa). Netherlands Journal of Sea Research 9: 69-85.

Last, J. M. (1979) The food of larval turbot Scophthalmus maximus L. from the west central North Sea. ICES Journal of Marine Science 38: 308-313.

Le Pape, O., F. Chauvet, S. Mahevas, P. Lazure, D. Guerault en Y. Desaunay (2003) Quantitative description of habitat suitability for the juvenile common sole (Solea solea, L.) in the Bay of Biscay (France) and the contribution of different habitats to the adult population. Journal of Sea Research 50: 139149.

Marchand, J. (1991) The influence of environmental conditions on settlement, distribution and growth of 0group sole (Solea solea (L.)) in a macrotidal estuary (Vilaine, France). Netherlands Journal of Sea Research 27: 307-316.

McConnaughey, R. A. en K. R. Smith (2000) Associations between flatfish abundance and surficial sediments in the eastern Bering Sea. Canadian journal of fisheries and aquatic sciences 57: 2410-2419.

Meeuwissen, L. (2014) Impact of the Sand Engine on the functioning of the coastal zone as nursery area for juvenile plaice Pleuronectes platessa (L.). MSc thesis, VU Amsterdam University, IJmuiden.

Mengedoht, D. M. (1995) Growth and Mortality of O-group Plaice Pleuronectes Platessa L. in Dutch Coastal Waters. NIOZ-RAPPORT 8: 3.

Meppelink, M. (2021) DNA based identification of European plaice diet along the Dutch North Sea coast, Wageningen University, Wageningen.

Millner, R. S. en C. L. Whiting (1996) Long-term changes in growth and population abundance of sole in the North Sea from 1940 to the present. ICES Journal of Marine Science 53: 1185-1195.

Nash, R. D. M. en A. J. Geffen (2000) The influence of nursery ground processes in the determination of year-class strength in juvenile plaice Pleuronectes platessa L. in Port Erin Bay, Irish Sea. Journal of Sea Research 44: 101-110.

Nasir, N. A. en M. G. Poxton (2001) Substratum preference of juvenile flatfish. Cybium 25: 109-117.

Nissling, A., U. Johansson en M. Jacobsson (2006) Effects of salinity and temperature conditions on the reproductive success of turbot (Scophthalmus maximus) in the Baltic Sea. Fisheries Research 80: 230-238.

Ojeda, E., B. Ruessink en J. Guillen (2008) Morphodynamic response of a two-barred beach to a shoreface nourishment. Coastal Engineering 55: 1185-1196.

Olds, A. D., E. Vargas-Fonseca, R. M. Connolly, B. L. Gilby, C. M. Huijbers, G. A. Hyndes, C. A. Layman, A. K. Whitfield en T. A. Schlacher (2018) The ecology of fish in the surf zones of ocean beaches: A global review. Fish and Fisheries 19: 78-89.

Pecceu, E., L. Colson, J. Wittoeck, J. Vanaverbeke, K. Hostens en G. Van Hoey (2015) Ecologische monitoring strand-en vooroever in functie van suppletie activiteiten: tussentijdse resulaten.

Pihl, L. (1989) Abundance, biomass and production of juvenile flatfish in southeastern kattegat. Netherlands Journal of Sea Research 24: 69-81.

Pilarczyk, K., H. Verhagen, P. Roelse, L. Adriaanse en J. Consemulder (1988) Handboek Zandsuppleties. uitgever waltman, isbn 9021231344.

Poiesz, S. S. H., A. de Vries, J. F. M. F. Cardoso, J. I. J. Witte, H. W. van der Veer en V. Freitas (2019) A comparison of growth in two juvenile flatfish species in the Dutch Wadden Sea: Searching for a mechanism for summer growth reduction in flatfish nurseries. Journal of Sea Research 144: 39-48.

Post, M. H. M., E. Blom, C. Chen, L. J. Bolle en M. J. Baptist (2017) Habitat selection of juvenile sole (Solea solea L.): Consequences for shoreface nourishment. Journal of Sea Research 122: 19-24.

Poxton, M. G., A. Eleftheriou en A. D. McIntyre (1983) The food and growth of 0-group flatfish on nursery grounds in the Clyde Sea Area. Estuarine, Coastal and Shelf Science 17: 319-337.

R Core Team (2020) R: A language and environment for statistical computing.R Foundation for Statistical Computing, Vienna, Austria.

Rakhorst, H. D. (1984) Werking strandhoofden Noord-Holland, Texel, Vlieland. Rijkswaterstaat, adviesdienst Hoorn, Nota WWKZ-84.H007, 15 pagina's. 
Reiss, H., I. Kroncke en S. Ehrich (2006) Estimating the catching efficiency of a 2-m beam trawl for sampling epifauna by removal experiments. ICES Journal of Marine Science 63: 1453-1464.

Rijnsdorp, A., F. Van Beek, S. Flatman, R. Millner, J. Riley, M. Giret en R. De Clerck (1992a) Recruitment of sole stocks, Solea solea (L.), in the Northeast Atlantic. Netherlands Journal of Sea Research 29: 173-192.

Rijnsdorp, A. D., F. A. van Beek, S. Flatman, J. M. Miller, J. D. Riley, M. Giret en R. de Clerk (1992b) Recruitment of sole, Solea solea (L.), in the Northeast Atlantic. Netherlands Journal Of Sea Research 29: 173-192.

Riley, J., D. Symonds, L. Woolner en R. Cross (1978), Turbot O-group year-class estimation along the English east coast from 1973 to 1976 Annales Biologiques.

Riley, J. (1981) On the factor influencing the dispersion of 0-group demersal fish in coastal waters. Rapp. P. Reun. Cons. Perm. Int. Explor. Mer 178: 223-228.

Riley, J. D. (1973) Movements of 0-group plaice Pleuronectes platessa L. as shown by latex tagging. Journal of Fish Biology 5: 323-343.

Rogers, S. I. (1993) The dispersion of sole, Solea solea and plaice, Pleuronectes platessa within and away from a nursery ground in the Irish Sea. Journal of Fish Biology 43: 275-288.

Rogers, S. I., A. D. Rijnsdorp, U. Damm en W. Vanhee (1998) Demersal fish populations in the coastal waters of the UK and continental NW Europe from beam trawl survey data collected from 1990 to 1995. Journal of Sea Research 39: 79-102.

Rutting, M. (2017) The growth of juvenile flatfish in Dutch coastal nursery areas, Wageningen University, Wageningen.

Simmonds, J. en D. N. MacLennan (2008) Fisheries acoustics: theory and practice, John Wiley \& Sons.

Speybroeck, J., D. Bonte, W. Courtens, T. Gheskiere, P. Grootaert, J. P. Maelfait, M. Mathys, S. Provoost, K. Sabbe en E. W. Stienen (2006) Beach nourishment: an ecologically sound coastal defence alternative? A review. Aquatic conservation: Marine and Freshwater ecosystems 16: 419-435.

Stankus, S. (2003) The peculiarities of turbot (Psetta maxima L.) biology and their role in the ecosystem of the Baltic Sea coastal zone of Lithuania. Acta Zoologica Lituanica 13: 217-238.

Støttrup, J., C. R. Sparrevohn, J. Modin en K. Lehmann (2002) The use of releases of reared fish to enhance natural populations: a case study on turbot Psetta maxima (Linne, 1758). Fisheries Research 59 : 161-180.

Teal, L. R., J. J. De Leeuw, H. W. Van der Veer en A. D. Rijnsdorp (2008) Effects of climate change on growth of 0-group sole and plaice. Marine Ecology Progress Series 358: 219-230.

Teal, L. R. en O. A. van Keeken (2011) The importance of the surf zone for fish and brown shrimp in The Netherlands IJmuiden : IMARES, (Report C054/11) - p. 80.

Teal, L. R., R. van Hal, T. van Kooten, P. Ruardij en A. D. Rijnsdorp (2012) Bio-energetics underpins the spatial response of North Sea plaice (Pleuronectes platessa L.) and sole (Solea solea L.) to climate change. Global Change Biology 18: 3291-3305.

Tien, N. S. H., J. Craeymeersch, C. van Damme, A. S. Couperus, J. Adema en I. Tulp (2017) Burrow distribution of three sandeel species relates to beam trawl fishing, sediment composition and water velocity, in Dutch coastal waters. Journal of Sea Research 127: 194-202.

Tinker, J., E. Howes, S. Wakelin, M. Menary, E. Kent en D. Berry (2020) The impacts of climate change on temperature (air and sea), relevant to the coastal and marine environment around the UK. MCCIP Science Reviews 2020: 1-3.

Tulp, I., C. Van Damme, F. Quirijns, E. Binnendijk en L. Borges (2006) Vis in de Voordelta: nulmetingen in het kader van de aanleg van de tweede Maasvlakte. IMARES.

Tulp, I., L. J. Bolle en A. D. Rijnsdorp (2008) Signals from the shallows: in search of common patterns in long-term trends in Dutch estuarine and coastal fish. Journal of Sea Research 60: 54-73.

Tulp, I., N. Tien en C. van Damme (2016a) PMR Monitoring natuurcompensatie Voordelta : ontwikkeling vis in de Voordelta na instelling bodembeschermingsgebied ter compensatie van de aanleg Tweede Maasvlakte. Wageningen Marine Research, Wageningen Marine Research rapport; No. C089/16.

Tulp, I., R. van Hal, C. J. G. van Damme en S. R. Smith (2016b) Zeebaars paaigebieden en opgroeigebieden in Nederlandse wateren. IMARES, Rapport / IMARES; No. C060/16.

van Beek, F. A., A. D. Rijnsdorp en R. de Clerck (1989) Monitoring juvenile stocks of flatfish in the Wadden Sea and the coastal areas of the southeastern North Sea. Helgoländer Meeresuntersuchungen 43 : 461-477.

Van Beek, F. A. (1997) Recruitment surveys on juvenile plaice and sole in continental nurseries in the North Sea by the Netherlands.

van Berkel, D. (2020) Optimal laboratory conditions for metabarcoding gut contents in juvenile plaice with nanopore sequencing, Wageningen University, Wageningen.

Van Dalfsen, J. A., H. Holzhauer en E. Verduin (2014) Veldverslag bemonstering Ameland \& Schiermonnikoog $4 \& 5$ augustus 2014. Delft, Deltares. 
van Damme, C., R. Hoek, D. Beare, L. Bolle, C. Bakker, E. Van Barneveld, M. Lohman, E. van Os-Koomen, P. Nijssen en I. Pennock (2011) Shortlist Master plan Wind Monitoring fish eggs and larvae in the southern North Sea: final report Part A en B.

van de Wolfshaar, K., I. Y. M. Tulp, H. Wennhage en J. G. Støttrup (2015) Modelling population effects of juvenile offshore fish displacement towards adult habitat. Marine Ecology Progress Series 540: 193201.

van de Wolfshaar, K. E., L. Barbut, G. Lacroix en M. Hidalgo (2021) From spawning to first-year recruitment: the fate of juvenile sole growth and survival under future climate conditions in the North Sea. ICES Journal of Marine Science.

van der Geest, M. (2019) Veldverslag strandsurvey Natuurlijk Veilig: Maart-juni 2019. Wageningen Marine Research.

van der Hammen, T., J. J. Poos, H. M. J. van Overzee, H. J. L. Heessen, A. Magnusson en A. D. Rijnsdorp (2013) Population ecology of turbot and brill: What can we learn from two rare flatfish species? Journal of Sea Research 84: 96-108.

van der Kaaij, T., T. van Kessel, T. Troost, P. Herman, L. van Duren en N. Villars (2017) Modelondersteuning MER winning suppletie- en ophoogzand Noordzee 2018-2027 : modelvalidatie. [Delft], Deltares.

van der Land, M. A. (1991) Distribution of flatfish eggs in the 1989 egg surveys in the southeastern North Sea, and mortality of plaice and sole eggs. Netherlands Journal of Sea Research 27: 277-286.

Van der Veer, H. W. en M. J. N. Bergman (1986) Development of tidally related behaviour of a newly settled 0 -group plaice (Pleuronectes platessa) population in the western Wadden Sea. Marine Ecology Progress Series 31: 121-129.

van der Veer, H. W. en M. J. Bergman (1987) Predation by crustaceans on a newly settled 0-group plaice Pleuronectes platessa population in the western Wadden Sea. Marine Ecology Progress Series 35: 203-215.

van der Veer, H. W., L. Pihl en M. J. N. Bergman (1990) Recruitment mechanisms in North Sea plaice Pleuronectes platessa. Marine Ecology Progress Series 64: 1-12.

Van der Veer, H. W. en J. I. Witte (1993) The 'maximum growth/optimal food condition'hypothesis: a test for 0 -group plaice Pleuronectes platessa in the Dutch Wadden Sea. Marine Ecology Progress Series 101: 81-90.

Van der Veer, H. W., R. Berghahn en A. D. Rijnsdorp (1994) Impact of juvenile growth on recruitment in flatfish. Netherlands Journal of Sea Research 32: 153-173.

Van der Veer, H. W., B. Bies en J. I. J. Witte (2000) Selective growth and mortality of juvenile 0-group plaice Pleuronectes platessa in the Dutch Wadden Sea: a consequence of irreversible non-genetic adaptation during early pelagic life. Marine Ecology Progress Series 197: 273-283.

van der Veer, H. W., R. Dapper en J. I. Witte (2001) The nursery function of the intertidal areas in the western Wadden Sea for 0-group sole Solea solea (L.). Journal of Sea Research 45: 271-279.

van der Veer, H. W., J. F. M. F. Cardoso, M. A. Peck en S. A. L. M. Kooijman (2009) Physiological performance of plaice Pleuronectes platessa (L.): A comparison of static and dynamic energy budgets. Journal of Sea Research 62: 83-92.

van der Veer, H. W., J. Koot, G. Aarts, R. Dekker, W. Diderich, V. Freitas en J. I. J. Witte (2011) Long-term trends in juvenile flatfish indicate a dramatic reduction in nursery function of the Balgzand intertidal, Dutch Wadden Sea. Marine Ecology Progress Series 434: 143-154.

van Dijk, T. A. G. P., C. van der Tak, W. P. de Boer, M. H. P. Kleuskens, P. J. Doornenbal, R. P. Noorlandt en V. C. Marges (2011) The scientific validation of the hydrographic survey policy of the Netherlands Hydrographic Office, Royal Netherlands Navy. DELTARES, Report 1201907-000-BGS-0008.

van Hal, R. (2013) Monitoring en Evaluatie Pilot Zandmotor Fase 2 - Data rapport vis- en epibenthosbemonstering najaar 2012. IMARES, Rapport/IMARES C005/13, 25 pagina's.

van Hal, R., T. van Kooten en A. D. Rijnsdorp (2016) Temperature induced changes in size dependent distributions of two boreal and three Lusitanian flatfish species: A comparative study. Journal of Sea Research 107, Part 1: 14-22.

van Hal, R. (2018) Ecologisch gericht suppleren: meetplan geïntegreerde ecosysteem survey 2018. Wageningen Marine Research.

van Hal, R. en A. Dijkman-Dulkes (2019) Reisverslag kustsurvey Natuurlijk Veilig: Juni 2019. Wageningen Marine Research.

van Hal, R., J. Volwater, G. Aarts, S. Brasseur, S. Glorius, R. v. Hal, J. Volwater, G. Aarts, S. Brasseur en S. Glorius (2021) Ecologische effecten van een pilotsuppletie in het Amelander Zeegat : synthese van onderzoeksresultaten en literatuur. Wageningen Marine Research rapport ; C004/21. IJmuiden, Wageningen Marine Research.

van Keeken, O., M. Van Hoppe, R. E. Grift en A. D. Rijnsdorp (2007) Changes in the spatial distribution of North Sea plaice (Pleuronectes platessa) and implications for fisheries management. Journal of Sea Research 57: 187-197. 
van Leeuwen, P. en A. Rijnsdorp (1986) Seizoensgroei van Noordzeetarbot en terugberekeningen van lengten door middel van otolieten. Rijksinstituut voor Visserijonderzoek.

Vandamme, S. G., G. E. Maes, J. A. M. Raeymaekers, K. Cottenie, A. K. Imsland, B. Hellemans, G. Lacroix, E. Mac Aoidh, J. T. Martinsohn, P. Martínez, J. Robbens, R. Vilas en F. A. M. Volckaert (2014) Regional environmental pressure influences population differentiation in turbot (Scophthalmus maximus). Molecular Ecology 23: 618-636.

Vasconcelos, R. P., D. B. Eggleston, O. Le Pape en I. Tulp (2014) Patterns and processes of habitat-specific demographic variability in exploited marine species. Ices Journal of Marine Science 71: 638-647.

Vinagre, C., A. Maia, P. Reis-Santos, M. J. Costa en H. N. Cabral (2009) Small-scale distribution of Solea solea and Solea senegalensis juveniles in the Tagus estuary (Portugal). Estuarine, Coastal and Shelf Science 81: 296-300.

Vrooman, J., M. de Vries en I. Tulp (2020a) Seizoensveranderingen in vis en epibenthos in de Waddenzee: pilotproject maandelijkse monitoring. Stichting Wageningen Research, Centrum voor Visserijonderzoek (CVO), CVO rapport; No. 20.006.

Vrooman, J., A. Dijkman-Dulkes en R. van Hal (2020b) Reisverslag kustsurvey Natuurlijk Veilig: juni 2020. Wageningen Marine Research).

Wijnhoven, S. (2008) Het omrekenen van Malvern resultaten tussen verschillende apparaten.

Wijsman, J. W. M., R. Van Hal en R. J. Jongbloed (2015) Monitoring en Evaluatie Pilot Zandmotor - Fase 2 Evaluatie benthos, vis, vogels en zeezoogdieren 2010 - 2014, IMARES C125/15, 109 pagina's.

Wolff, W. J., M. A. Mandos en A. J. J. Sandee (1981) Tidal Migration of Plaice and Flounders as a Feeding Strategy, Pages 159-171 in N. V. Jones, en W. J. Wolff, eds. Feeding and Survival Srategies of Estuarine Organisms. Boston, MA, Springer US.

Wolfshaar, K. E. v. d., S. T. Glorius en M. T. v. d. Sluis (2009) Habitat suitability rules for the shallow coastal zone in The Netherlands : project report. Report / IMARES Wageningen UR ; C064/12. IJmuiden [etc.], IMARES Wageningen UR.

Wyche, C. J. en S. E. Shackley (1986) The feeding ecology of Pleuronectes platessa L., Limanda limanda (L.) and Scophthalmus rhombus (L.) in Carmarthen Bay, South Wales, U.K. Journal of Fish Biology 29: 303-311.

Zijlstra, J. (1972), On the importance of the Waddensea as a nursery area in relation to the conservation of the southern North Sea fishery resources Symp. Zool. Soc. Lond. 29:233-258.

Zijlstra, J., R. Dapper en J. I. Witte (1982) Settlement, growth and mortality of post-larval plaice (Pleuronectes platessa) in the western Wadden Sea. Netherlands Journal of Sea Research 15: 250272. 


\section{Verantwoording}

Rapport C077/21

Projectnummer: 4312100053

Dit rapport is met grote zorgvuldigheid tot stand gekomen. De wetenschappelijke kwaliteit is intern getoetst door een collega-onderzoeker en het verantwoordelijk lid van het managementteam van Wageningen Marine Research

Akkoord:

Martin Baptist

Senior onderzoeker

Handtekening:

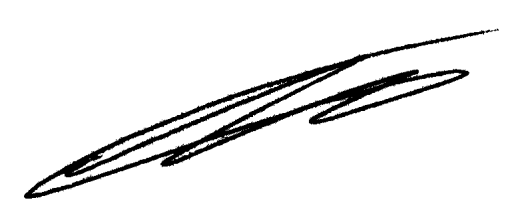

Datum:

12 oktober 2021

Akkoord:

Drs. J. Asjes

Manager Integratie

Handtekening:

Datum:

12 oktober 2021 


\section{Bijlage 1 Aangetroffen vissen}

Totale lijst met aangetroffen vissoorten en de aantallen per jaar en bemonsteringstype. Er zit een groot verschil in aantal monsternames per jaar, de bemonsterde locaties en bemonsteringstype. Direct vergelijken van aantallen is daardoor niet mogelijk. De blauwe gearceerde soorten zijn de pelagische soorten. Clupeidae zijn niet op soort gebrachte haring/sprot, in de meeste gevallen larven/vroege juvenielen met name gevangen in de Strandbemonstering van 2019. Grondels (Pomatoschistus lozanoi \& $P$. minutes) en zandspiering (Ammodytes tobianus \& $A$. marinus) zijn maar in een beperkt aantal gevallen op soort gebracht omdat het lastig is op basis van visuele kenmerken, en daarom hier samengevoegd.

\begin{tabular}{|c|c|c|c|c|c|c|c|c|c|c|}
\hline \multirow[b]{2}{*}{ Nederlandse naam } & \multicolumn{2}{|l|}{2017} & \multirow[b]{2}{*}{ Strand } & \multicolumn{2}{|l|}{2018} & \multirow[b]{2}{*}{ Strand } & \multicolumn{2}{|l|}{2019} & \multicolumn{2}{|l|}{2020} \\
\hline & Luctor & Rubberboot & & Luctor & Rubberboot & & Luctor & Strandbemonstering & Luctor & totaal \\
\hline Haring & 13825 & 1141 & 325 & 46 & 92 & 60 & 48832 & 2934 & 80979 & 148234 \\
\hline Schol & 3990 & 344 & 45 & 1887 & 7 & 2 & 1145 & 322 & 1462 & 9204 \\
\hline Clupeidae & 1 & 3 & 2 & & & & & 2836 & 3009 & 5851 \\
\hline Kleine zeenaald & 239 & 14 & 1 & 164 & 3 & & 1714 & 19 & 1109 & 3263 \\
\hline Zandspieringen indet. & 565 & 29 & 119 & 14 & & 6 & 576 & 35 & 1777 & 3121 \\
\hline Wijting & 663 & 12 & & 329 & & & 683 & 1 & 299 & 1987 \\
\hline Sprot & 150 & 49 & 2 & 569 & & & 131 & 9 & 926 & 1836 \\
\hline Grondel & 678 & 2 & 2 & 53 & 9 & & 139 & 40 & 203 & 1126 \\
\hline Glasgrondel & 352 & 6 & 1 & 69 & 1 & & 313 & 4 & 301 & 1047 \\
\hline Schar & 604 & 2 & & 15 & & & 16 & & 57 & 694 \\
\hline Tong & 174 & 54 & 1 & 7 & & & 71 & 29 & 294 & 630 \\
\hline Smelt & 68 & 10 & & & & & 350 & 1 & 25 & 454 \\
\hline Steenbolk & 32 & & & & & & 114 & & 190 & 336 \\
\hline Bot & 42 & 7 & 1 & 1 & & & 93 & 16 & 77 & 237 \\
\hline Schurftvis & 85 & & & & & & & & 1 & 86 \\
\hline Harnasmannetje & 38 & & & 28 & & & & & 2 & 68 \\
\hline Kleine pieterman & 38 & 5 & 7 & & & 1 & 8 & 1 & 2 & 62 \\
\hline Dwergbolk & 5 & & & 29 & & & 14 & & 13 & 61 \\
\hline Tarbot & 8 & 1 & & & & & 17 & 23 & 3 & 52 \\
\hline Dwergtong & 45 & & & & & & & & & 45 \\
\hline Botervis & 24 & & & & & & 3 & & 17 & 44 \\
\hline Makreel & & & & & & & 1 & & 43 & 44 \\
\hline Spiering & & & & & & & 3 & & 36 & 39 \\
\hline Pitvis & 24 & & & 12 & & & 1 & & & 37 \\
\hline Griet & 15 & 7 & 4 & & & & 4 & 4 & 1 & 35 \\
\hline Driedoornige stekelbaars & 18 & & & 4 & & & 1 & 7 & & 30 \\
\hline Vijfdradige meun & 3 & & & & & & & & 21 & 24 \\
\hline Harders indet. & 9 & 1 & & 3 & & & 1 & 3 & & 17 \\
\hline Rode poon & 10 & & & & & & 2 & & 5 & 17 \\
\hline Slakdolf & 3 & & & 7 & & & & & 7 & 17 \\
\hline Rasterpitvis & 16 & & & & & & & & & 16 \\
\hline Rivierprik & 3 & & & 5 & & & 5 & & & 13 \\
\hline Zeebaars & & & 1 & & & & & 8 & & 9 \\
\hline Tongschar & 4 & & 1 & & & & 1 & & & 6 \\
\hline Horsmakreel & & & & & & & & & 5 & 5 \\
\hline Puitaal & & & & & & & & & 5 & 5 \\
\hline Zeedonderpad & & & & & & & 4 & & 1 & 5 \\
\hline Grote zeenaald & 1 & & & 1 & & & & & 2 & 4 \\
\hline Ansjovis & 1 & & & & & & & & 2 & 3 \\
\hline Franse tong & 3 & & & & & & & & & 3 \\
\hline Grauwe poon & 3 & & & & & & & & & 3 \\
\hline Kabeljauw & 1 & & & & & & 2 & & & 3 \\
\hline Brakwatergrondel & & & & & & & 2 & & & 2 \\
\hline Groene zeedonderpad & & & & & & & 1 & & 1 & 2 \\
\hline $\begin{array}{l}\text { Koornaarvissen indet. } \\
\text { Geep }\end{array}$ & & & & 1 & & & & 2 & & $\begin{array}{l}2 \\
1\end{array}$ \\
\hline Gladde haai & & & & 1 & & & & & & 1 \\
\hline Witje & 1 & & & & & & & & & 1 \\
\hline Zwartbekgrondel & & & & & & & & & 1 & 1 \\
\hline Zwarte koolvis & & & & & & & & & 1 & 1 \\
\hline
\end{tabular}


Voor de historische gegevens geldt ook dat er grote verschillen zitten in het aantal monsters per periode en survey. De historische strandbemonstering beslaat een groter gebied dan alleen de brandingszone, deze bevat ook monsters uit dieper water.

\begin{tabular}{|c|c|c|c|c|c|}
\hline \multirow[b]{2}{*}{ Nederlandse naam } & \multicolumn{3}{|c|}{ Historische strandbemonstering } & \multirow{2}{*}{\begin{tabular}{|l} 
DFS \\
Voorjaar
\end{tabular}} & \multirow[b]{2}{*}{ Najaar } \\
\hline & Voorjaar & Zomer & Najaar & & \\
\hline Schol & 2207 & 1845 & 2612 & 63464 & 136580 \\
\hline Schar & 603 & 315 & 16051 & 32954 & 194963 \\
\hline Grondels indet. & 5723 & 730 & 5709 & 2916 & 210618 \\
\hline Tong & 440 & 830 & 389 & 11058 & 79811 \\
\hline Zeenaalden indet. & 335 & 20 & 223 & 4 & 5943 \\
\hline Sprot & 195 & 873 & 41 & 9254 & 25234 \\
\hline Kleine zeenaald & 139 & 72 & 229 & & \\
\hline Haring & 117 & 624 & 97 & 4855 & 48314 \\
\hline Tarbot & 78 & 40 & 60 & 243 & 1252 \\
\hline Kleine zandspiering & 77 & 1 & 3 & & \\
\hline Wijting & 48 & 385 & 67 & 2964 & 36379 \\
\hline Bot & 46 & 3 & 4 & 1910 & 901 \\
\hline Spiering & 33 & 26 & 28 & 12 & 179 \\
\hline Zandspieringen indet. & 30 & 40 & 3 & 660 & 4317 \\
\hline Vijfdradige meun & 30 & 1 & 23 & 307 & 721 \\
\hline Slakdolf & 29 & 22 & 5 & 2 & 915 \\
\hline Pitvis & 29 & 47 & & 4581 & 9963 \\
\hline Driedoornige stekelbaars & 28 & 1 & & 76 & 52 \\
\hline Harnasmannetje & 18 & 12 & 24 & 644 & 5074 \\
\hline Dwergtong & 15 & & 2 & 886 & 9538 \\
\hline Steenbolk & 14 & 105 & 22 & 1924 & 16545 \\
\hline Zeedonderpad & 11 & 3 & 23 & 55 & 85 \\
\hline Griet & 11 & 43 & 13 & 72 & 351 \\
\hline Rode poon & 8 & 13 & 5 & 171 & 394 \\
\hline Schurftvis & 7 & & & 343 & 880 \\
\hline Zeebaars & 5 & & & 1 & 7 \\
\hline Koornaarvis indet. & 5 & 11 & & 399 & 76 \\
\hline Zeestekelbaars & 4 & & & & \\
\hline Kabeljauw & 4 & & & 1028 & 2079 \\
\hline Smelt & 3 & 1 & & 102 & 281 \\
\hline Kleine pieterman & 3 & 26 & 1 & 49 & 5511 \\
\hline Horsmakreel & 3 & 341 & 5 & 257 & 3258 \\
\hline Grote zeenaald & 3 & & 1 & 115 & \\
\hline Aal & 3 & 1 & 1 & 70 & 1220 \\
\hline Puitaal & 1 & & 2 & 30 & 115 \\
\hline Grauwe poon & 1 & 13 & & 339 & 549 \\
\hline Glasgrondel & 1 & 21 & & & \\
\hline Fint & 1 & & & 249 & 5547 \\
\hline Dwergbolk & 1 & 1 & & 227 & 1768 \\
\hline Adderzeenaald & 1 & & & 14 & 3 \\
\hline Makreel & & 2 & & 2 & 64 \\
\hline Snotolf & & 1 & & 1 & 78 \\
\hline Driedradige meun & & & 2 & & 1 \\
\hline Botervis & & & 1 & 1 & 21 \\
\hline Lange schar & & & & 41 & \\
\hline Ansjovis & & & & 11 & 201 \\
\hline Harders indet. & & & & 8 & 16 \\
\hline Schelvis & & & & 4 & 1 \\
\hline Dwergbot & & & & 2 & \\
\hline Geep & & & & 2 & 12 \\
\hline Tongschar & & & & 2 & 10 \\
\hline Hondshaai & & & & 1 & \\
\hline Zwarte koolvis & & & & 1 & 3 \\
\hline Pelser & & & & 1 & \\
\hline Mul & & & & & 230 \\
\hline Vierdradige meun & & & & & 41 \\
\hline Rasterpitvis & & & & & 21 \\
\hline Kever & & & & & 18 \\
\hline Zeeprik & & & & & 7 \\
\hline
\end{tabular}




\section{Bijlage 2 Aangetroffen overige soorten}

\begin{tabular}{|c|c|c|c|c|c|c|c|c|c|c|}
\hline \multirow[b]{2}{*}{ Nederlandse naam } & \multicolumn{2}{|l|}{2017} & \multirow[b]{2}{*}{ Strand } & \multicolumn{2}{|l|}{2018} & \multirow[b]{2}{*}{ Strand } & \multicolumn{2}{|c|}{2019} & \multicolumn{2}{|c|}{2020} \\
\hline & Luctor R & Rubberboot & & Luctor $\mathrm{F}$ & Rubberboot & & Luctor S & Strandbemonstering & Luctor & totaal \\
\hline Gewone garnaal & 140843 & 38126 & 18 & \begin{tabular}{l|l}
3 & 13982
\end{tabular} & 313 & 441 & 45193 & 16620 & 209849 & \begin{tabular}{l|l}
9 & 465385 \\
\end{tabular} \\
\hline Zwemkrab sp. & 5785 & 115 & 1 & 280 & & & 949 & 33 & 18382 & 25545 \\
\hline Halfgeknotte strandschelp & 4461 & 5 & & & & & 20 & & 566 & 5052 \\
\hline Zeedruif & 127 & 4 & 4 & 3071 & 5 & & 169 & 759 & 1 & 4140 \\
\hline Kleine heremietkreeft & 1005 & 1143 & 2 & 11 & 118 & 9 & 139 & 9 & 322 & 2758 \\
\hline Amerikaanse langlob-ribkwal & 5 & 3 & & 378 & 2 & 2 & 134 & 2090 & & 2614 \\
\hline Strandkrab & 419 & 131 & 1 & 72 & 1 & 3 & 213 & 300 & 975 & 2115 \\
\hline Oorkwal & 151 & 40 & 16 & 759 & 5 & 31 & 246 & 35 & 124 & 1407 \\
\hline Gewone heremietkreeft & 729 & 66 & & 85 & 9 & & 183 & 36 & 104 & 1212 \\
\hline Slangster & 668 & 10 & & 3 & & & 209 & & 105 & 995 \\
\hline Ribkwallen indet. & & 6 & & & 6 & 13 & & 933 & & 958 \\
\hline Haarkwal & 106 & 9 & 1 & 360 & 5 & 35 & 178 & 190 & 52 & 936 \\
\hline Zeester & 365 & 5 & 21 & 216 & 1 & & 43 & 44 & 20 & 715 \\
\hline Aasgarnalen & & 3 & & & & & & 190 & 432 & 625 \\
\hline Kompaskwal & 125 & 1 & 3 & 41 & & 10 & 44 & 11 & 192 & 427 \\
\hline Dwergpijlinktvis & 24 & 6 & & 54 & 3 & & 128 & & 182 & 397 \\
\hline Tere platschelp & 320 & & & & & & & & & 320 \\
\hline Breedpootkrab & 20 & 131 & 1 & 1 & & 1 & 52 & 78 & 3 & 286 \\
\hline Steurgarnaal & & & & & & & & & 258 & 258 \\
\hline Mossel & 1 & 11 & & & & & & 152 & 2 & 166 \\
\hline Fuikhoorns indet. & 55 & & & & & & 39 & 3 & 2 & 99 \\
\hline Zaagje & 47 & 2 & & & & & 10 & 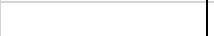 & 37 & 96 \\
\hline Zeepaddestoel & 74 & 1 & & 8 & & 4 & t & 2 & 4 & 93 \\
\hline Langvinpijlinktvissen indet. & 18 & 1 & & & & & & 5 & 68 & 92 \\
\hline Kwallen & 4 & & & & & & & 85 & & 89 \\
\hline Nonnetje & 77 & & & & 1 & & & & 9 & 87 \\
\hline Hartegel & 8 & & & 1 & & & 37 & & 31 & 77 \\
\hline Zwaardschedes indet. & 20 & & & 3 & & & 3 & 30 & 4 & 60 \\
\hline Klepelklokje & & & & 48 & 7 & & & & & 55 \\
\hline Driepuntsgarnaal & 36 & & & 10 & 2 & & & 1 & 3 & 52 \\
\hline Goudkammetje & & & & & & & & 45 & & 45 \\
\hline Zeerasp & 15 & 3 & & & & & 15 & & 1 & 34 \\
\hline Strandschelpen indet. & 14 & & & & & & 9 & & . & 23 \\
\hline Helmkrab & 10 & & & 11 & & & & & 1 & 22 \\
\hline Purperen zeeklit & 13 & & & 4 & & & & & . & 17 \\
\hline Zeeanemonen & 10 & 1 & & & & & & & 4 & 15 \\
\hline Vlokreeften indet. & & & & 29 & 202 & & 11 & 88 & 4 & 334 \\
\hline Noordzeekrab & 8 & & & 1 & & & & 2 & 1 & 12 \\
\hline Gewimperde zwemkrab & 6 & & & & & & 1 & & 2 & 9 \\
\hline Blauwpootzwemkrab & & 8 & & & & & & & & 8 \\
\hline Brokkelster & 6 & & & & & & & & & 6 \\
\hline Zeepissebedden & & & & 2 & & & & 6 & & 8 \\
\hline Kokkel & & & & & & & & & 5 & 5 \\
\hline Slibanemoon & & & & & & & & 5 & s. & 5 \\
\hline Chinese wolhandkrab & & & & & & & & 4 & t & 4 \\
\hline Muiltje & & & & & & & 1 & & 2 & 3 \\
\hline Tepelhoorns indet. & 1 & & & & & & 1 & 1 & & 3 \\
\hline Gorgelpijppoliep & 2 & & & & & & & & & 2 \\
\hline Pennenschacht & 2 & & & & & & & & & 2 \\
\hline zeeslak & & & & & & & & 1 & & 1 \\
\hline Amerikaanse boormossel & 1 & & & & & & & & & 1 \\
\hline Fluwelen zwemkrab & 1 & & & & & & & & & 1 \\
\hline Kamster & 1 & & & & & & & & & 1 \\
\hline Kleine slangster & & & & & & & 1 & & & 1 \\
\hline Lampenkapje & 1 & & & & & & & & & 1 \\
\hline Pindaworm & & & & & & & & 1 & & 1 \\
\hline Veelkleurige zeeduizendpoot & & & & & & & & 1 & & 1 \\
\hline Venusschelp & 1 & & & & & & & & & 1 \\
\hline Viltkokeraemoon & & & & & & & & 1 & & 1 \\
\hline Wulk & & 1 & & & & & & & & 1 \\
\hline Zeeappel & 1 & & & & & & & & & 1 \\
\hline Zeepokken & 1 & & & & & & & & & 1 \\
\hline
\end{tabular}




\section{Gewone garnaal}

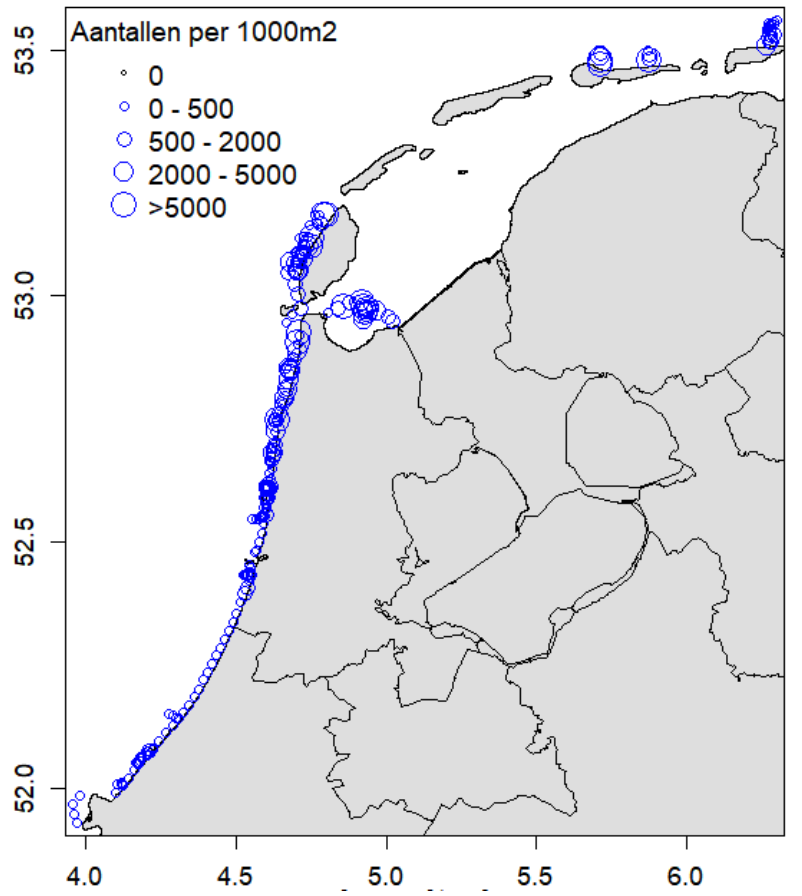

Strandkrab

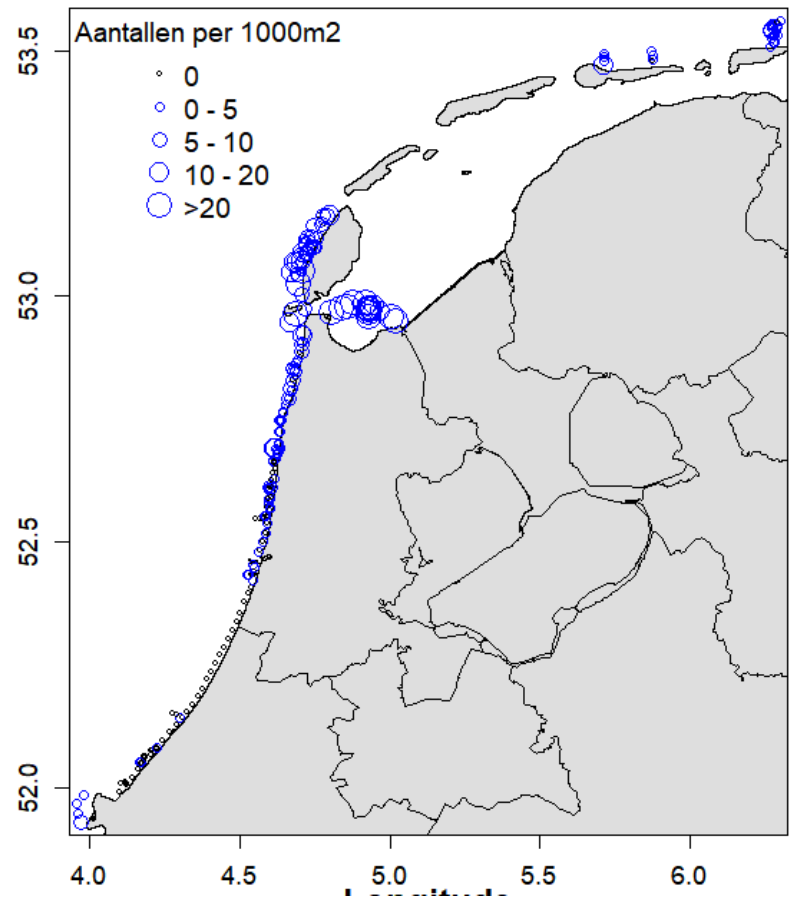

Gewone zwemkrab

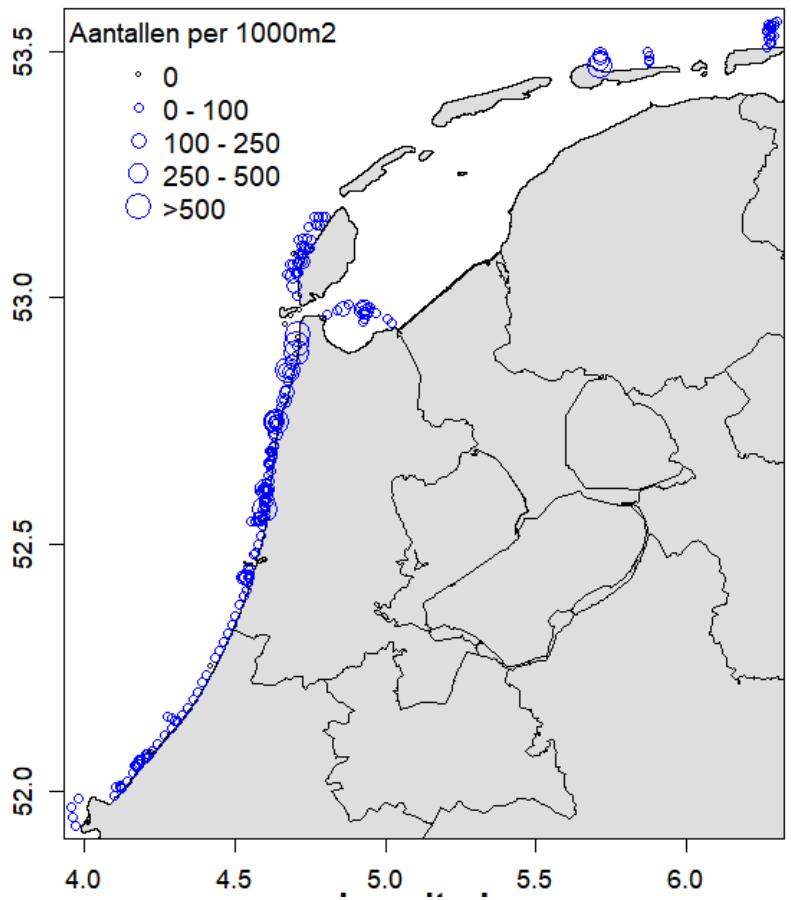

Kleine heremiet

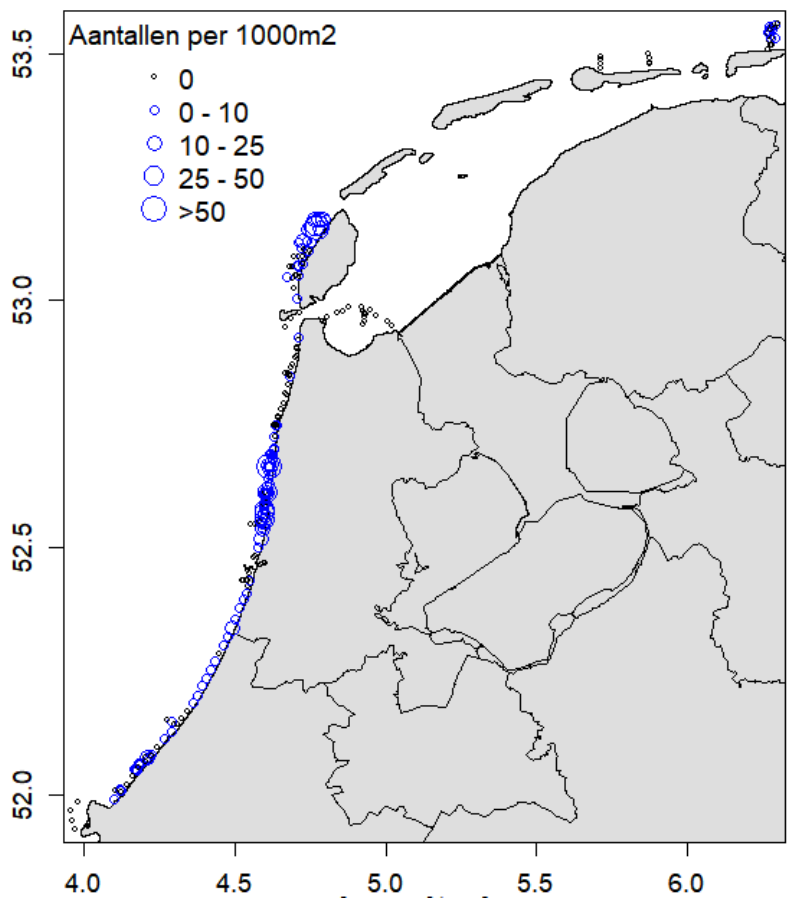

Figuur b 1 Verspreiding van gewone garnaal, gewone zwemkrab, strandkrab en kleine heremiet in de Luctor-monsters van 2018-2020. 


\section{Bijlage 3 Beschermingsdoelen}

De vooroever valt binnen de Habitatrichtlijn in habitattype 1110b: permanent overstroomde zandbanken (Noordzee-kustzone). Binnen de habitatrichtlijn en voor habitat 1110b worden een aantal vissoorten genoemd waarvoor er beschermingsdoelen zijn.

In de habitatrichtlijn worden de vissoorten Elft (Alosa alosa), Fint (Alosa Fallax), rivierprik (Lampetra fluviatilis), en zalm (Salmo salar) genoemd, welke in de vooroever voor kunnen komen. Het zijn allen soorten die maar tijdelijk in de vooroever verblijven of hier door trekken. Voor deze soorten wordt er tijdens de levensfase waarin ze in de vooroever verblijven geen relatie met het sediment of het diepteprofiel zoals zou kunnen veranderen door suppleties verwacht. Van deze soorten is alleen rivierprik waargenomen in de eerste drie jaar van de Natuurlijk Veilig bemonsteringen met de Luctor. De beperkte waarnemingen van deze soort maken het niet mogelijk hier enige analyse op uit te voeren. Om meer inzicht te krijgen in deze soorten, welke in beperkte aantallen voorkomen, is een heel ander soort onderzoeksprogramma nodig dan waarvoor gekozen is binnen Natuurlijk Veilig.

Voor habitat $1110 \mathrm{~b}$ worden als typische soorten genoemd:

- dwergtong (Buglossidium luteum),

- $\quad$ haring (Clupea harengus),

- kleine pieterman (Echiichthys vipera),

- pitvis (Callionymus lyra),

- schol (Pleuronectes platessa),

- $\quad$ tong (Solea solea),

- wijting (Merlangius merlangus),

- harnasmannetje (Agonus cataphractus),

- Schurftvis (Arnoglossus laterna),

- Vijfdradige meun (Ciliata mustela),

- slakdolf (Liparis liparis),

- zeedonderpad (Myoxocephalus scorpius)

De platvissen schol en tong zijn uitgebreid behandeld in het hoofdrapport. Ook voor wijting zijn in het hoofdrapport analyses gerapporteerd. Haring als pelagische soort is behandeld in het rapport over de pelagische bemonsteringen (Couperus e.a., 2020).

De zeedonderpad en de slakdolf zijn in zeer lage aantallen aangetroffen. De vijfdradige meun werd nagenoeg alleen aangetroffen in de stations in de Waddenzee. Dwergtong en schurftvis laten de verwachtte verspreiding in dieper water zien.

Dwergtong is alleen aangetroffen in trekken dieper dan $8 \mathrm{~m}$, waarvan driekwart in het beperkt aantal trekken uitgevoerd in water dieper dan $10 \mathrm{~m}$. Schurftvis is alleen aangetroffen in waterdieptes van 5 $\mathrm{m}$ of dieper, 18 keer werd er een aangetroffen in water in de diepterange tussen 5-10m, de overige 68 individuen werden aangetroffen in het beperkte aantal trekken in dieper water. De ondiepe kustzone is voor deze beide platvissoorten geen voorkeurshabitat.

De kleine pieterman is een aantal keer aangetroffen in de strandbemonstering. Uit nieuwsberichten is het bekend dat deze soort in warme zomers in de branding aangetroffen wordt. Echter in 2020, dat een zeer warm jaar was, werd maar één exemplaar van deze soort in de strandbemonstering ter hoogte van IJmuiden gevangen. Het harnasmannetje en pitvis zijn niet aangetroffen in de brandingszone. Voor alle drie de soorten geldt dat het aantal aangetroffen individuen beperkt is, ze verspreidt zijn over de gehele diepterange en daarnaast en ook ruimtelijk verspreid zijn over het gehele bemonsterde gebied. 


\section{Bijlage 4 Statistische analyse historische data}

Voor de historische data in hoofdstuk 4 zijn analyses uitgevoerd om te bepalen of de dichtheden van een soort significant verschilden per diepteklasse. Voor de gegevens van de historische strandbemonsteringen zijn er per diepte klassen drie willekeurige waarnemingen gekozen waarvan het gemiddelde is berekend, dit is vervolgens honderd keer herhaald wat resulteert in een dataset van honderd gemiddelde op basis van willekeurige waarnemingen. Doormiddel van een ANOVA gevolgd door een Tukey's HSD-test is aan de hand van de gecreëerde dataset gekeken of de dichtheden per diepteklassen significant van elkaar verschillen.

Voor de historische DFS data is dezelfde statistische methode toegepast, alleen zijn 5 willekeurige waarnemingen gekozen vanwege de grotere bemonsteringsinspanning per diepteklassen.

In onderstaande tabellen zijn de resultaten van de Tukey's HSD-test voor de verschillende soorten en leeftijdsgroepen weergegeven per seizoen. Boven ieder resultaat staat het figuur uit de hoofdtekst waarvoor deze resultaten gelden. In de Tukey-resultaten worden steeds twee diepteklasse met elkaar vergeleken. Diff geeft aan het verschil tussen de twee gemiddelde, een negatieve waarde betekent dat de dichtheden in de eerste genoemde diepteklasse gemiddeld hoger waren dan in de als tweede genoemde diepteklasse. De $\mathrm{P}$ is de $\mathrm{P}$-waarde en geeft aan of dit verschil significant is.

Figuur 4.1 (Schol 0-groep)

\begin{tabular}{lllllll} 
& \multicolumn{2}{c}{ Voorjaar } & \multicolumn{1}{c}{ Zomer } & \multicolumn{3}{c}{ Najaar } \\
Diepteklassen & Diff & P & Diff & P & Diff & P \\
"0-2" - "2-5 & -0.32 & $\mathbf{0 . 0}$ & 0.30 & $\mathbf{0 . 0 0 0 1}-0.2$ & $\mathbf{0 . 0 4}$ \\
"0-2" - "5-10" & -0.37 & $\mathbf{0 . 0}$ & 0.49 & $\mathbf{0 . 0}$ & -0.93 & $\mathbf{0 . 0}$ \\
"2-5" - "5-10" & -0.05 & 0.2 & 0.19 & $\mathbf{0 . 0 2 3}$ & -0.73 & $\mathbf{0 . 0}$
\end{tabular}

Figuur 4.2 (Schol I-groep)

\begin{tabular}{lllllll} 
& \multicolumn{2}{c}{ Voorjaar } & \multicolumn{1}{c}{ Zomer } & \multicolumn{3}{c}{ Najaar } \\
Diepteklassen & Diff & P & Diff & P & Diff & P \\
"0-2" - "2-5 & -0.66 & $\mathbf{0 . 0}$ & -0.13 & 0.12 & 0.14 & $\mathbf{0 . 0 0 0 6}$ \\
"0-2" - "5-10" & -0.44 & $\mathbf{0 . 0}$ & 0.16 & $\mathbf{0 . 0 4}$ & -0.13 & $\mathbf{0 . 0 0 1 4}$ \\
"2-5" - "5-10" & 0.22 & $\mathbf{0 . 0 1 5}$ & 0.29 & $\mathbf{0 . 0}$ & -0.27 & $\mathbf{0 . 0}$
\end{tabular}

Figuur 4.3 (Schol DFS)

\begin{tabular}{lllll} 
& \multicolumn{2}{c}{ Voorjaar } & \multicolumn{3}{c}{ Najaar } \\
Diepteklassen & Diff & P & Diff & P \\
"2-5" - "5-10" & -0.27 & $\mathbf{0 . 0 1}$ & -1.01 & $\mathbf{0 . 0}$ \\
"2-5" - "> 10" & -1.25 & $\mathbf{0 . 0}$ & -2.04 & $\mathbf{0 . 0}$ \\
"5-10" - "> 10" & -0.98 & $\mathbf{0 . 0}$ & -1.03 & $\mathbf{0 . 0}$
\end{tabular}


Figuur 4.4 (Tong 0-groep)

\begin{tabular}{lllllll} 
& \multicolumn{2}{c}{ Voorjaar } & \multicolumn{2}{c}{ Zomer } & \multicolumn{3}{c}{ Najaar } \\
Diepteklassen & Diff & P & Diff & P & Diff & P \\
"0-2" - "2-5 & & & 0.51 & $\mathbf{0 . 0}$ & 0.71 & $\mathbf{0 . 0}$ \\
"0-2" - "5-10" & & & 0.54 & $\mathbf{0 . 0}$ & 0.37 & $\mathbf{0 . 0}$ \\
"2-5" - "5-10" & & & 0.04 & 0.87 & -0.34 & $\mathbf{0 . 0}$
\end{tabular}

Figuur 4.5 (Tong I-groep)

\begin{tabular}{lllllll} 
& \multicolumn{2}{c}{ Voorjaar } & \multicolumn{2}{c}{ Zomer } & Najaar \\
Diepteklassen & Diff & P & Diff & P & Diff & P \\
"0-2" - "2-5 & 0.73 & $\mathbf{0 . 0}$ & 0.15 & $\mathbf{0 . 0 2}$ & \\
"0-2" - "5-10" & 1.08 & $\mathbf{0 . 0}$ & 0.41 & $\mathbf{0 . 0}$ & \\
"2-5" - "5-10" & 0.35 & $\mathbf{0 . 0}$ & 0.26 & $\mathbf{0 . 0}$ &
\end{tabular}

Figuur 4.6 (Tong DFS)

\begin{tabular}{lllll} 
& \multicolumn{2}{c}{ Voorjaar } & \multicolumn{3}{c}{ Najaar } \\
Diepteklassen & Diff & P & Diff & P \\
"2-5" - "5-10" & -1.09 & $\mathbf{0 . 0}$ & -0.20 & 0.099 \\
"2-5" - "> 10" & -1.22 & $\mathbf{0 . 0}$ & -1.32 & $\mathbf{0 . 0}$ \\
"5-10" - "> 10" & -0.13 & 0.167 & -1.12 & $\mathbf{0 . 0}$
\end{tabular}

Figuur 4.7 (Tarbot)

\begin{tabular}{lllllll} 
& \multicolumn{2}{c}{ Voorjaar } & \multicolumn{1}{c}{ Zomer } & \multicolumn{3}{c}{ Najaar } \\
Diepteklassen & Diff & P & Diff & P & Diff & P \\
"0-2" - "2-5 & -0.57 & $\mathbf{0 . 0}$ & -0.16 & $\mathbf{0 . 0}$ & -0.55 & $\mathbf{0 . 0}$ \\
"0-2" - "5-10" & -0.61 & $\mathbf{0 . 0}$ & -0.30 & $\mathbf{0 . 0}$ & -0.67 & $\mathbf{0 . 0}$ \\
"2-5" - "5-10" & -0.04 & 0.52 & -0.14 & $\mathbf{0 . 0}$ & -0.12 & $\mathbf{0 . 0 0 3 2}$
\end{tabular}

Figuur 4.8 (Griet)

\begin{tabular}{lllllll} 
& \multicolumn{2}{c}{ Voorjaar } & \multicolumn{2}{c}{ Zomer } & \multicolumn{3}{c}{ Najaar } \\
Diepteklassen & Diff & P & Diff & P & Diff & P \\
"0-2" - "2-5 & -0.15 & $\mathbf{0 . 0}$ & -0.02 & 0.864 & -0.17 & $\mathbf{0 . 0}$ \\
"0-2" - "5-10" & -0.10 & $\mathbf{0 . 0}$ & -0.16 & $\mathbf{0 . 0 0 0 4}-0.30$ & $\mathbf{0 . 0}$ \\
"2-5" - "5-10" & 0.05 & 0.12 & -0.14 & $\mathbf{0 . 0 0 2 9}-0.13$ & $\mathbf{0 . 0}$
\end{tabular}




\section{Bijlage 5 Statistische analyse recente gegevens}

Voor de recente gegevens in hoofdstuk 5 zijn analyses uitgevoerd om te bepalen of de dichtheden in de Luctor-vangsten significant verschilden per Kustvak. Hiervoor is dezelfde methode gevolgd als voor de analyses van de historische gegevens. Er zijn willekeurig 5 monsters per kustvak genomen, wat vervolgens honderd keer is herhaald.

In onderstaande tabellen zijn de resultaten van de Tukey's HSD-test weergegeven.

Figuur 5.10 totale aantallen in de kustvakbemonstering

\begin{tabular}{lllll}
\multicolumn{1}{c}{ diff } & Iwr & upr & p adj \\
N-H-AMEL & -0.03185417 & -0.11105791 & 0.04734956 & 0.8059674 \\
SCHI-AMEL & -0.01830398 & -0.09750771 & 0.06089976 & 0.9697195 \\
TEX-AMEL & 0.09720188 & 0.01799815 & 0.17640561 & $\mathbf{0 . 0 0 7 4 6 3 0}$ \\
Z-H-AMEL & -0.82261894 & -0.90182268 & -0.74341521 & $\mathbf{0 . 0 0 0 0 0 0 0}$ \\
SCHI-N-H & 0.01355020 & -0.06565353 & 0.09275393 & 0.9901177 \\
TEX-N-H & 0.12905606 & 0.04985232 & 0.20825979 & $\mathbf{0 . 0 0 0 0 9 8 3}$ \\
Z-H-N-H & -0.79076477 & -0.86996850 & -0.71156104 & $\mathbf{0 . 0 0 0 0 0 0 0}$ \\
TEX-SCHI & 0.11550586 & 0.03630213 & 0.19470959 & $\mathbf{0 . 0 0 0 7 1 4 6}$ \\
Z-H-SCHI & -0.80431497 & -0.88351870 & -0.72511123 & $\mathbf{0 . 0 0 0 0 0 0 0}$ \\
Z-H-TEX & -0.91982082 & -0.99902456 & -0.84061709 & $\mathbf{0 . 0 0 0 0 0 0 0}$
\end{tabular}

Figuur 5.10 totale biomassa in de kustvakbemonstering diff Iwr upr $\quad \mathrm{padj}$

$\begin{array}{lllll}\text { N-H-AMEL } & -129.60349 & -192.481595 & -66.72538 & \mathbf{0 . 0 0 0 0 0 0 3} \\ \text { SCHI-AMEL } & -74.15141 & -137.029523 & -11.27331 & \mathbf{0 . 0 1 1 5 4 2 4} \\ \text { TEX-AMEL } & 340.74121 & 277.863106 & 403.61932 & \mathbf{0 . 0 0 0 0 0 0 0} \\ \text { Z-H-AMEL } & -222.73361 & -285.611720 & -159.85550 & \mathbf{0 . 0 0 0 0 0 0 0} \\ \text { SCHI-N-H } & 55.45207 & -7.426035 & 118.33018 & 0.1131073 \\ \text { TEX-N-H } & 470.34470 & 407.466594 & 533.22281 & \mathbf{0 . 0 0 0 0 0 0 0} \\ \text { Z-H-N-H } & -93.13012 & -156.008232 & -30.25202 & \mathbf{0 . 0 0 0 5 5 5 2} \\ \text { TEX-SCHI } & 414.89263 & 352.014521 & 477.77074 & \mathbf{0 . 0 0 0 0 0 0 0} \\ \text { Z-H-SCHI } & -148.58220 & -211.460305 & -85.70409 & \mathbf{0 . 0 0 0 0 0 0 0} \\ \text { Z-H-TEX } & -563.47483 & -626.352934 & -500.59672 & \mathbf{0 . 0 0 0 0 0 0 0}\end{array}$

Figuur 5.14 aantallen schol in de kustvakbemonstering

$\begin{array}{lllll} & \text { diff } & \text { Iwr } & \text { upr } & \text { p adj } \\ \text { N-H-AMEL } & 0.621745 & 0.533545 & 0.709946 & 0 \\ \text { SCHI-AMEL } & 0.676823 & 0.588622 & 0.765023 & 0 \\ \text { TEX-AMEL } & 0.339156 & 0.250955 & 0.427356 & 0 \\ \text { Z-H-AMEL } & -0.95578 & -1.04398 & -0.86758 & 0 \\ \text { SCHI-N-H } & 0.055078 & -0.03312 & 0.143278 & 0.428908 \\ \text { TEX-N-H } & -0.28259 & -0.37079 & -0.19439 & 0 \\ \text { Z-H-N-H } & -1.57753 & -1.66573 & -1.48933 & 0 \\ \text { TEX-SCHI } & -0.33767 & -0.42587 & -0.24947 & 0 \\ \text { Z-H-SCHI } & -1.63261 & -1.72081 & -1.54441 & 0 \\ \text { Z-H-TEX } & -1.29494 & -1.38314 & -1.20674 & 0\end{array}$


Figuur 5.14 biomassa schol in de kustvakbemonstering

$\begin{array}{lllll} & \text { diff } & \text { Iwr } & \text { upr } & \text { p adj } \\ \text { N-H-AMEL } & 141.6897 & 114.9916 & 168.3878 & \mathbf{0 . 0 0 E + 0 0} \\ \text { SCHI-AMEL } & 199.6719 & 172.9738 & 226.37 & \mathbf{0 . 0 0 E + 0 0} \\ \text { TEX-AMEL } & 63.82338 & 37.12529 & 90.52148 & \mathbf{0 . 0 0 E + 0 0} \\ \text { Z-H-AMEL } & -76.0967 & -102.795 & -49.3987 & \mathbf{0 . 0 0 E + 0 0} \\ \text { SCHI-N-H } & 57.98217 & 31.28407 & 84.68027 & \mathbf{1 . 0 0 E - 0 7} \\ \text { TEX-N-H } & -77.8663 & -104.564 & -51.1682 & \mathbf{0 . 0 0 E + 0 0} \\ \text { Z-H-N-H } & -217.786 & -244.485 & -191.088 & \mathbf{0 . 0 0 E + 0 0} \\ \text { TEX-SCHI } & -135.848 & -162.547 & -109.15 & \mathbf{0 . 0 0 E + 0 0} \\ \text { Z-H-SCHI } & -275.769 & -302.467 & -249.071 & \mathbf{0 . 0 0 E + 0 0} \\ \text { Z-H-TEX } & -139.92 & -166.618 & -113.222 & \mathbf{0 . 0 0 E + 0 0}\end{array}$




\section{Bijlage 6 Omgevingsvariabelen}

Tijdens alle veldwerkzaamheden zijn er omgevingsvariabelen geregistreerd. Met behulp van de CTD op het vistuig zijn continue de saliniteit en temperatuur geregistreerd. Tijdens de gelopen stations is dit gedaan eenmalig gedaan met een multimeter. Doorzicht is gemeten met behulp van een Secchi-schijf. De metingen zijn niet in alle gevallen gelukt, in aantal monster stations ontbreekt hierdoor.

In de watertemperatuur is op basis van de 2019 data de verandering over de tijd te zien, met koude temperaturen in maart oplopend naar de temperaturen in juni/juli. De juni temperaturen lagen tussen 16-19 ${ }^{\circ} \mathrm{C}$, met enkele uitschieters in het ondiepe water (en in 20202 de Waddenzee). De watertemperatuur verandert ook over de dag, met warmer water in de middag dan in de ochtend (van Hal en Dijkman-Dulkes, 2019).

In zoutgehalte is duidelijke variatie te zien in de monsters genomen tijdens de strandbemonsteringen. De laagste waarden zijn allen gemeten tijdens de bemonstering van het strand van Katwijk, de monsterlocatie lag direct ten Noorden van het afwateringskanaal van de Oude Rijn. Verder zijn de locaties langs de zuid en noord Hollandse kust minder zout dan de noordelijkere locaties (van Hal en Dijkman-Dulkes, 2019) door de rivierafvoer die met name in het zuiden plaatsvind.

Doorzicht is zeer variabel met duidelijke verschillen tussen dagen. Het weer is van invloed, met ruiger weer wordt het doorzicht beperkt, wat duidelijk is terug te zien tijdens de het veldwerk (van Hal en Dijkman-Dulkes, 2019). Het doorzicht heeft invloed op de vangstefficiëntie van de tuigen.
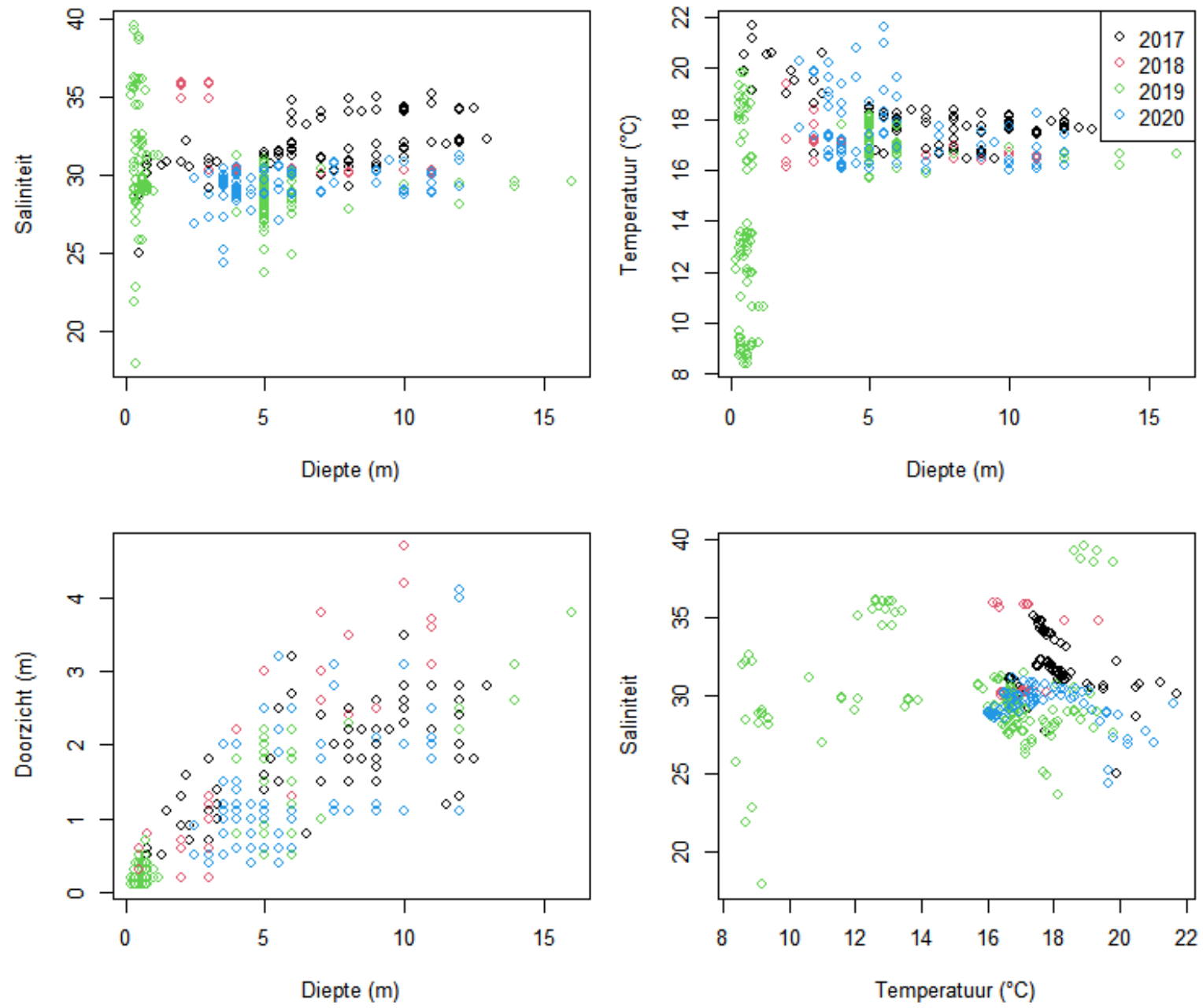

Figuur b 2 Saliniteit, Temperatuur en doorzicht tegen de diepte aan de start van de trek. En Saliniteit tegen de temperatuur. De kleuren representeren de verschillende bemonsteringsjaren. 

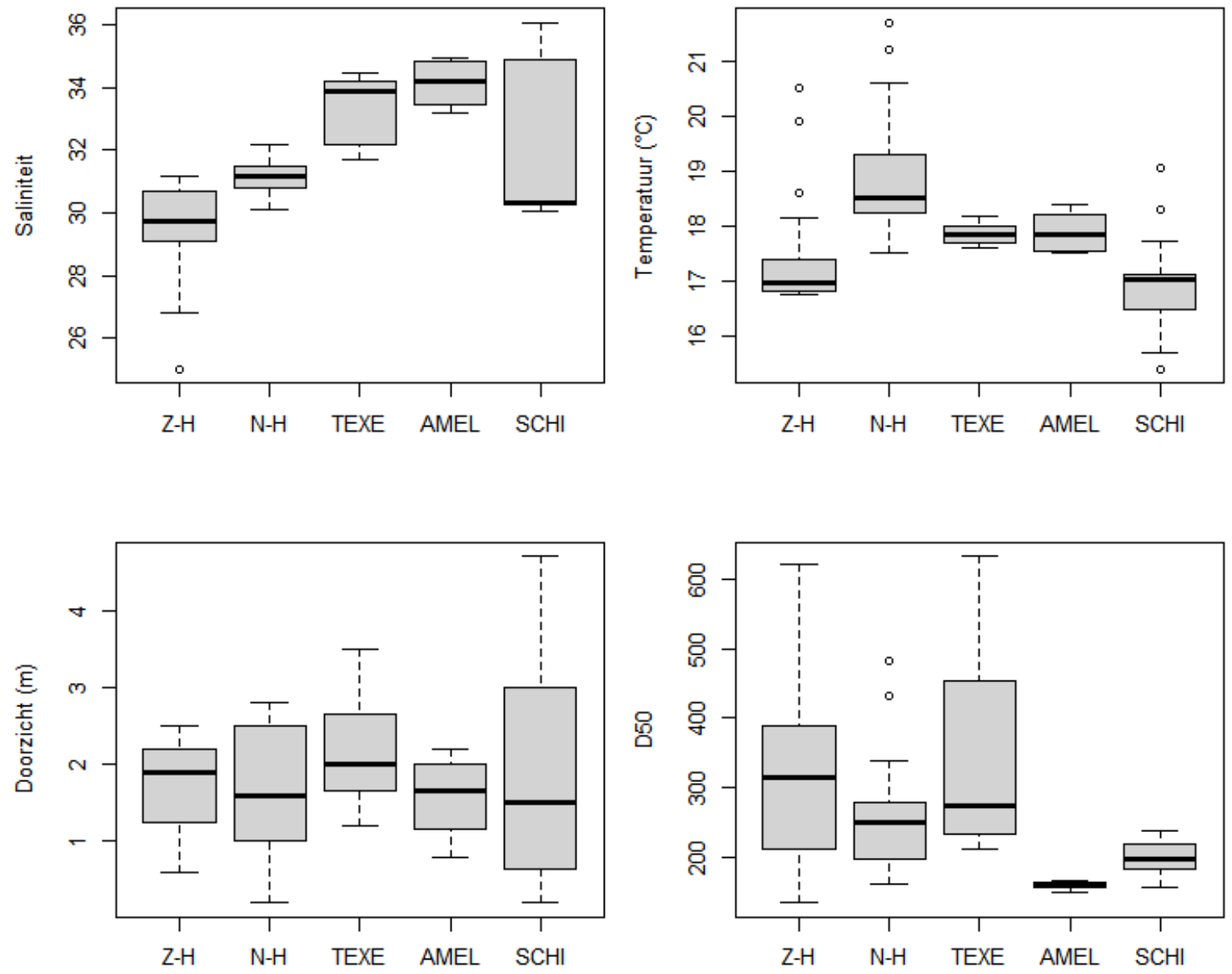

Figuur b 3 Saliniteit, temperatuur, doorzicht en mediane korrelgrootte (D50) in de verschillende kustvakken. 


\section{Bijlage 7 Zandmotor-bemonsteringen}

In 2011-2013 en 2015, zijn er bemonsteringen uitgevoerd in het kader van de aanleg van de Zandmotor. In 2011 zijn deze uitgevoerd in het najaar. In de ander drie jaar op het eind van de zomer. De bemonsteringen zijn uitgevoerd met een $3 \mathrm{~m}$ boomkor, vergelijkbaar als die gebruikt vanaf de Luctor, met een maaswijdte van $22 \mathrm{~mm}$ in 2011 en $20 \mathrm{~mm}$ in de andere jaren. De trekduur lag in 2011 rond de 15 minuten en in de andere jaren rond de 5 minuten. De verspreiding van monsterlocaties is zeer vergelijkbaar in de verschillende jaren (Figuur b 4), met uitzondering van 2011, toen de Zandmotor nog niet was aangelegd. Ter vergelijking met gegevens uit de Natuurlijk Veilig bemonsteringen zijn vergelijkbare figuren gemaakt over de vangsten van demersale vis in aantallen en gewichten (Figuur b 5).

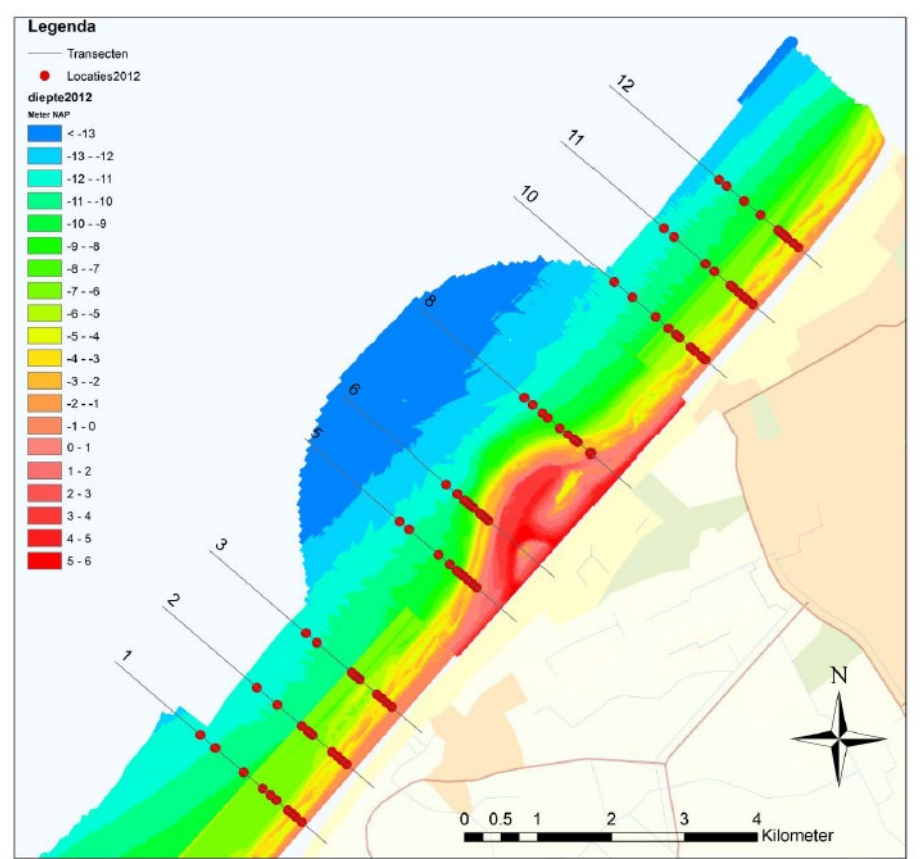

Figuur b 4 Monitoringsopzet van de Zandmotorbemonsteringen in 2011-2013 en 2015.
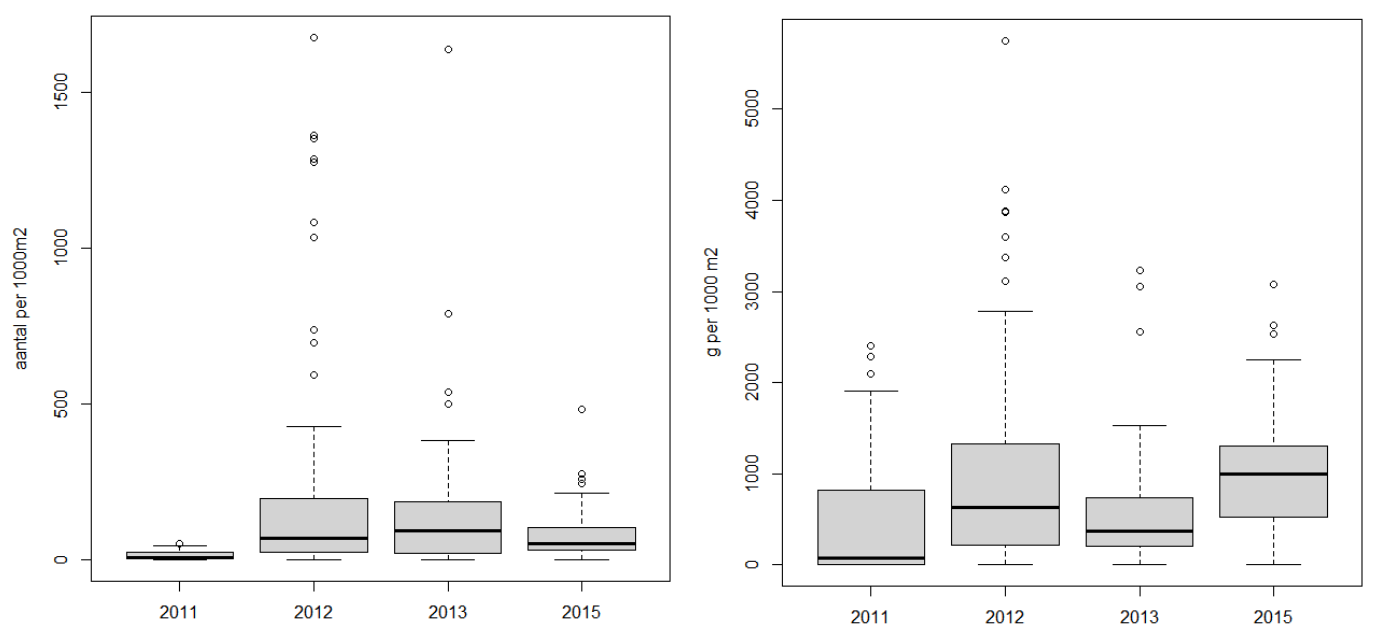

Figuur b 5 Totaalaantal en totaalgewicht demersale vis per $1000 \mathrm{~m}^{2}$ per jaar voor de Zandmotorbemonsteringen. 


\section{Bijlage 8 Resultaten GAM-analyse}
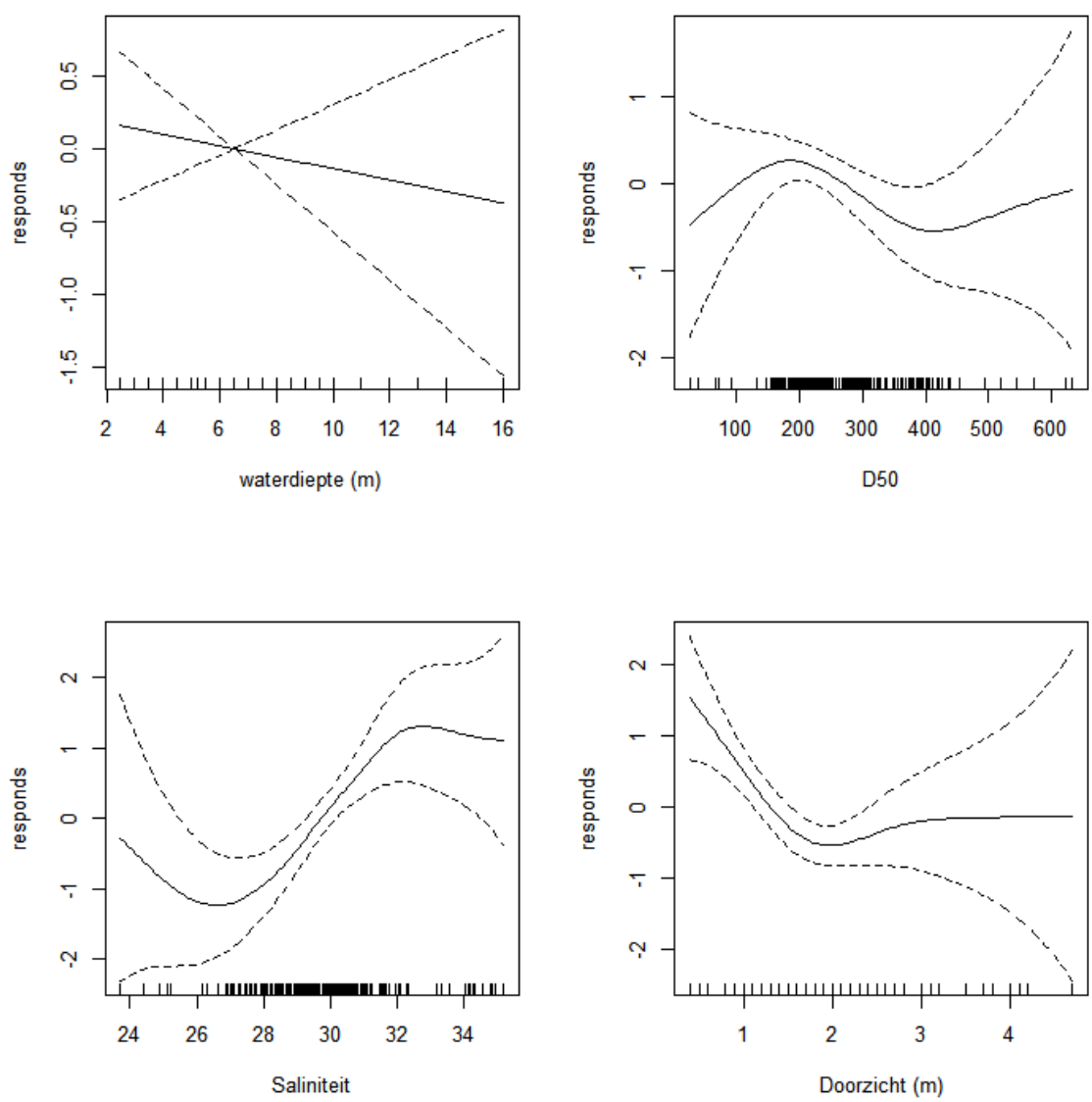

Figuur b 6 Schol: de resultaten van de GAM-analyse op basis van de Luctor-gegevens verzameld tijdens Natuurlijk Veilig. Alleen Saliniteit en doorzicht zijn significant. 

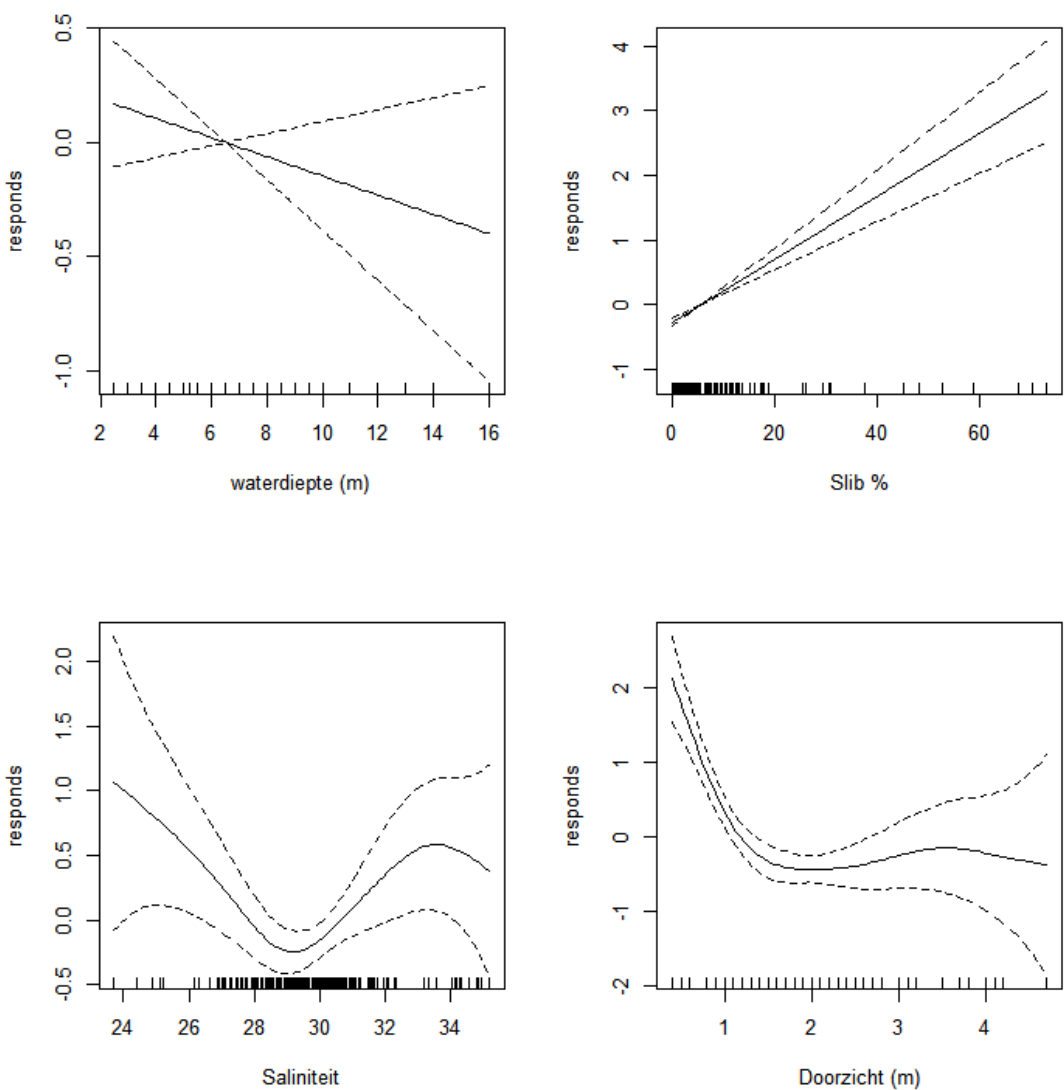

Figuur b 7 Tong: de resultaten van de GAM-analyse op basis van de Luctor-gegevens verzameld tijdens Natuurlijk Veilig. Slibgehalte, saliniteit en doorzicht zijn significant.
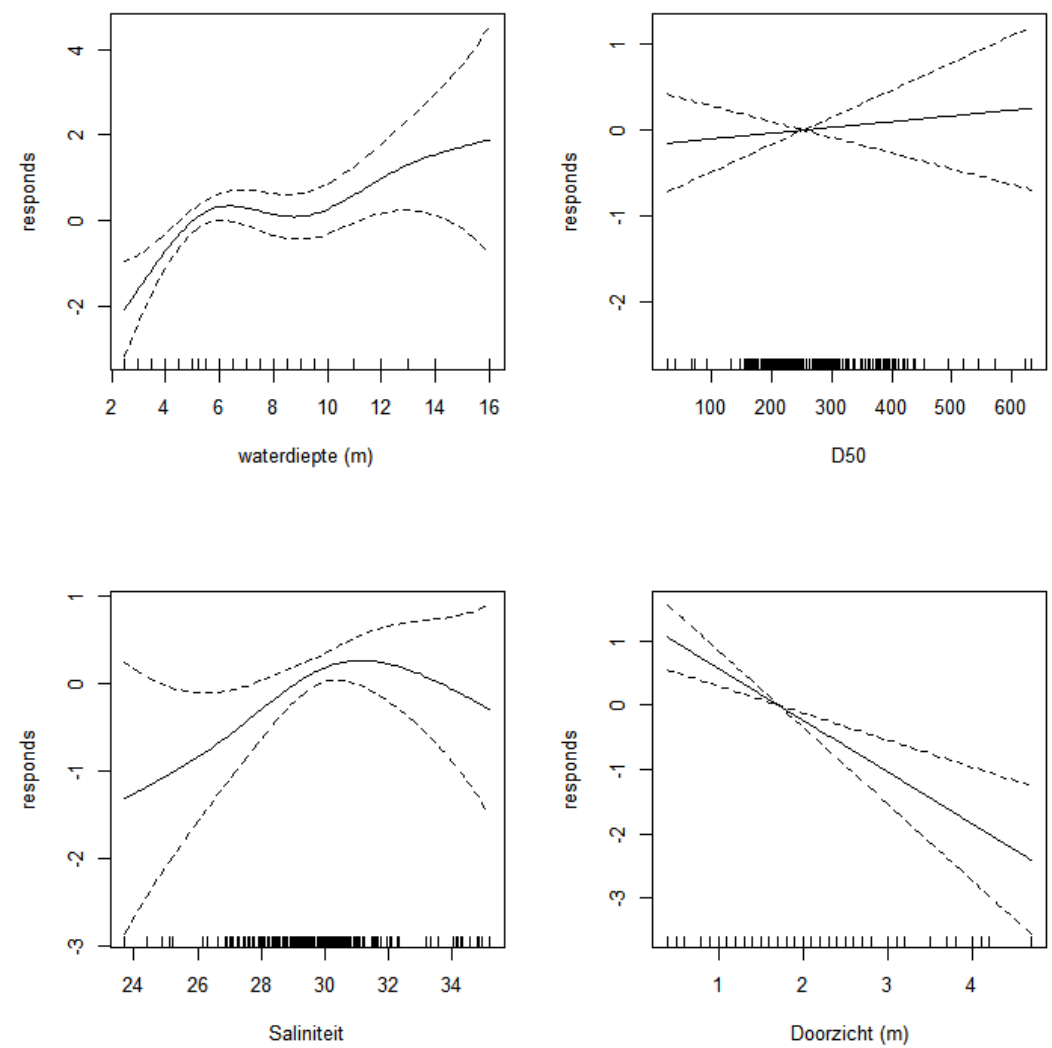

Figuur b 8 Wijting: de resultaten van de GAM-analyse op basis van de Luctor-gegevens verzameld tijdens Natuurlijk Veilig. Waterdiepte en doorzicht zijn significant. 

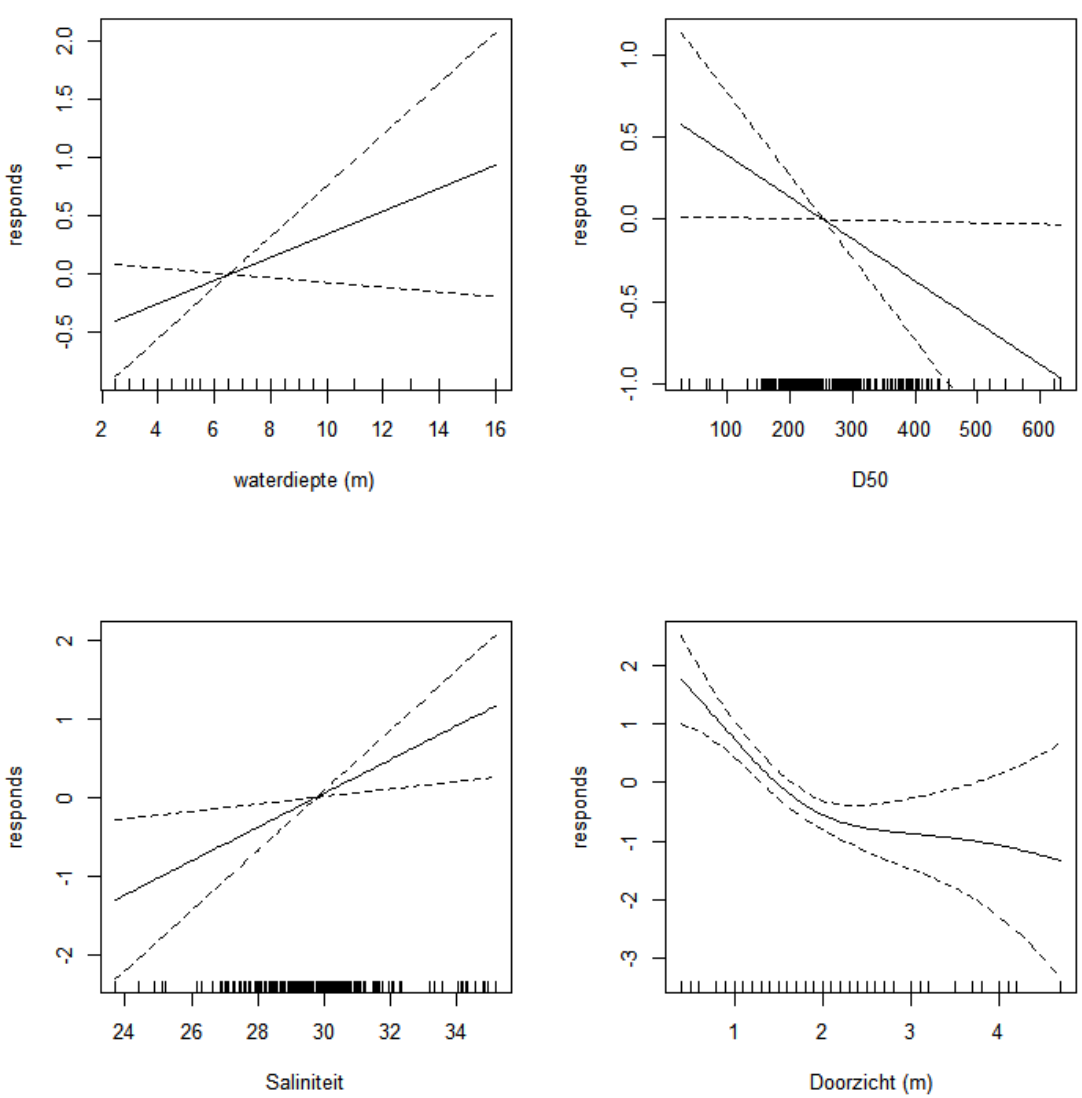

Figuur b 9 Kleine zeenaald: de resultaten van de GAM-analyse op basis van de Luctor-gegevens verzameld tijdens Natuurlijk Veilig. Saliniteit en doorzicht zijn significant.
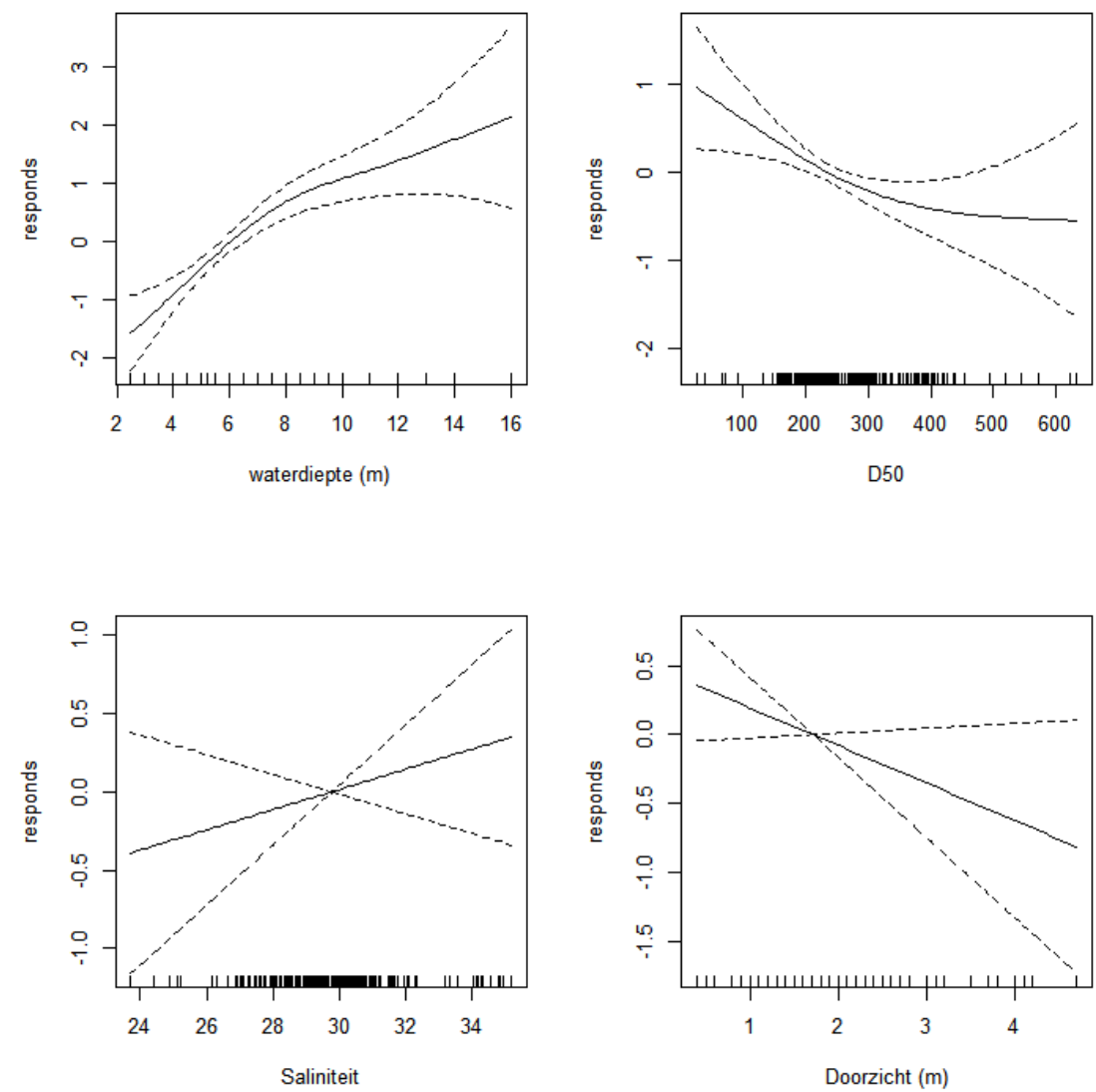

Figuur b 10 Grondel: de resultaten van de GAM-analyse op basis van de Luctor-gegevens verzameld tijdens Natuurlijk Veilig. Waterdiepte en D50 zijn significant. 

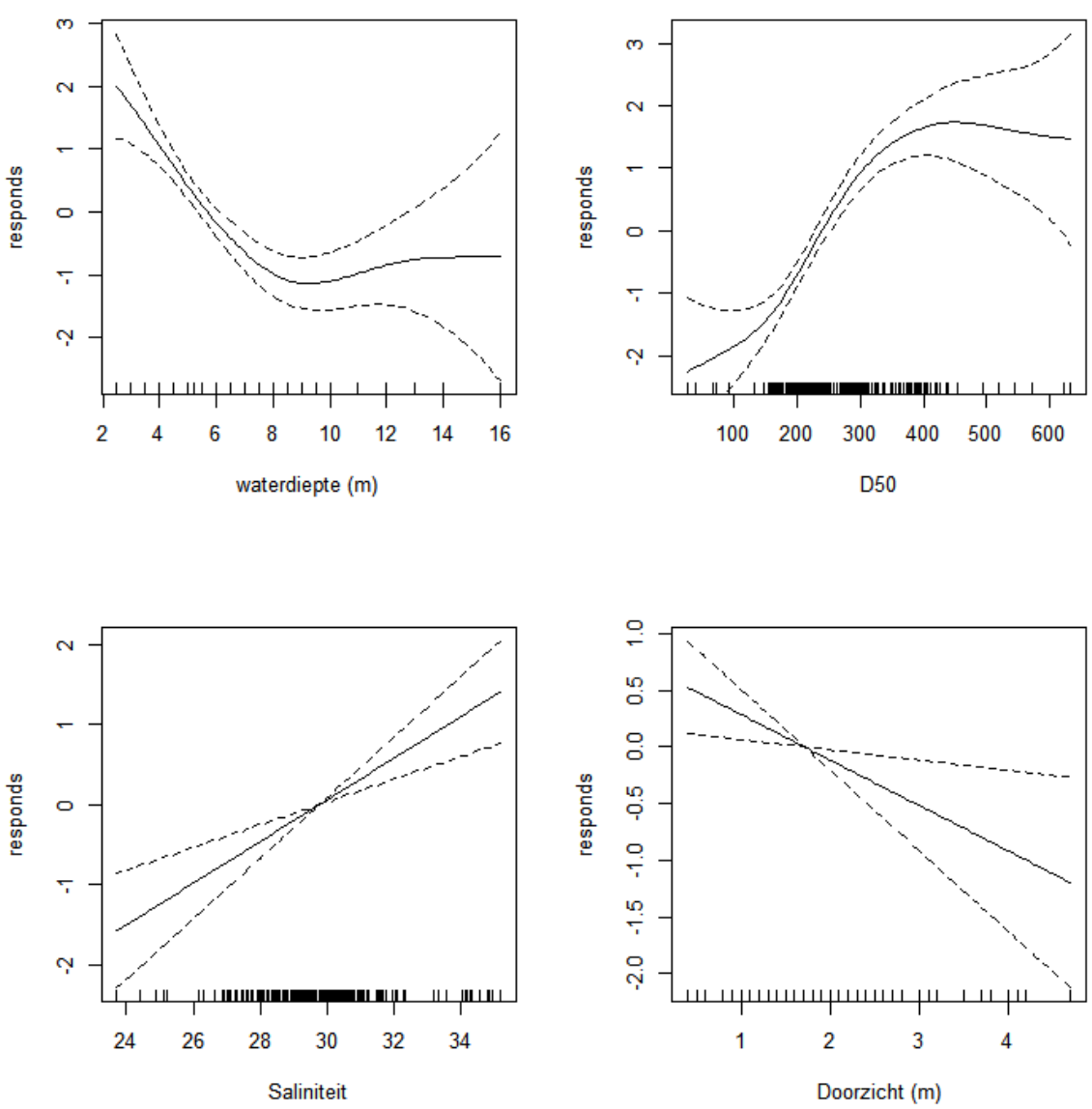

Figuur b 11 Zandspiering: de resultaten van de GAM-analyse op basis van de Luctor-gegevens verzameld tijdens Natuurlijk Veilig. Alle vier de variabelen zijn significant. 


\section{Bijlage 9 Tarbot en Griet}

De vangsten van tarbot (52) en griet (35) in de bemonsteringen van Natuurlijk Veilig waren laag. Om toch een beter inzicht te krijgen van deze soorten in de vooroever en kustzone is er gebruik gemaakt van WMR FRISBE-database waaruit de programma's zijn geselecteerd die in de kustzone en Waddenzee zijn uitgevoerd gebruikmakend van een $40 \mathrm{~mm}$ of kleinere maaswijdte.

\begin{tabular}{|c|c|c|c|c|}
\hline Programma & Beschrijving & Belangrijkste Gebied & Maaswijdte $(\mathrm{mm})$ & Periode \\
\hline DFS & $\begin{array}{l}\text { Reguliere demersal fish beam } \\
\text { trawl survey }\end{array}$ & $\begin{array}{l}\text { Kustwateren, } \\
\text { Waddenzee, Scheldes }\end{array}$ & 20 & $\begin{array}{l}\text { Q12: } 1970-1986 \\
\text { Q34: } 1970-2019\end{array}$ \\
\hline SNS & Reguliere sole net fish survey & $\begin{array}{l}\text { Transecten vanaf de } \\
\text { kustzone naar } \\
\text { offshore water. }\end{array}$ & 40 & $\begin{array}{l}\text { Q12:1969-1986 } \\
+2003 \\
\text { Q34:1969-2019 (- } \\
2003)\end{array}$ \\
\hline DISCRAN & $\begin{array}{l}\text { Observer programma aan } \\
\text { boord garnalenkotters }\end{array}$ & $\begin{array}{l}\text { Waddenzee en } \\
\text { kustwateren }\end{array}$ & $20-26$ & Q1234:2008-2018 \\
\hline MARE & $\begin{array}{l}\text { Baseline programma } \\
\text { Vliegveld in Zee }\end{array}$ & Kustwateren & $\begin{array}{l}40 \& 20 \& \text { enkele } \\
\text { met } 1 \text { (binnenzak). }\end{array}$ & Q123: 2000-2002 \\
\hline MILZON & $\begin{array}{l}\text { Programma verspreiding } \\
\text { vis/benthos in relatie tot } \\
\text { omgeving }\end{array}$ & Kustwateren & 40 & Q12:1996-1998 \\
\hline NSWDEM & $\begin{array}{l}\text { Programma impact van het } \\
\text { eerste Nederlandse offshore } \\
\text { windpark }\end{array}$ & Kustwateren & $40 \& 20$ & $\begin{array}{l}\text { Q234:2003 } \\
\text { Q1: } 2004 \& 2008 \\
\text { Q23: } 2007 \\
\text { Q123:2011 }\end{array}$ \\
\hline MVII & $\begin{array}{l}\text { Programma impact } \\
\text { natuurcompensatie in relatie } \\
\text { tot de } 2^{\text {de }} \text { Maasvlakte }\end{array}$ & Voordelta & 20 & Q234: 2004-2018 \\
\hline EGS & Natuurlijk Veilig & $\begin{array}{l}\text { Kustwateren + } \\
\text { brandingszone }\end{array}$ & $10 \& 20$ & Q2: 2017-2020 \\
\hline STRAND & $\begin{array}{l}\text { Historisch en recente } \\
\text { strandbemonstering }\end{array}$ & Brandingszone & $10 \& 20$ & $\begin{array}{l}\text { Q1234: 1974-1983, } \\
2020 \\
\text { Q3:1985, 2011, } 2019\end{array}$ \\
\hline ZMON & $\begin{array}{l}\text { Bemonsteringen rondom de } \\
\text { Zandmotor }\end{array}$ & $\begin{array}{l}\text { Brandingszone+ } \\
\text { Vooroever }\end{array}$ & $10-22$ & $\begin{array}{l}\text { Q4: } 2011+2015 \\
\text { Q23:2012 } \\
\text { Q234: } 2013\end{array}$ \\
\hline
\end{tabular}
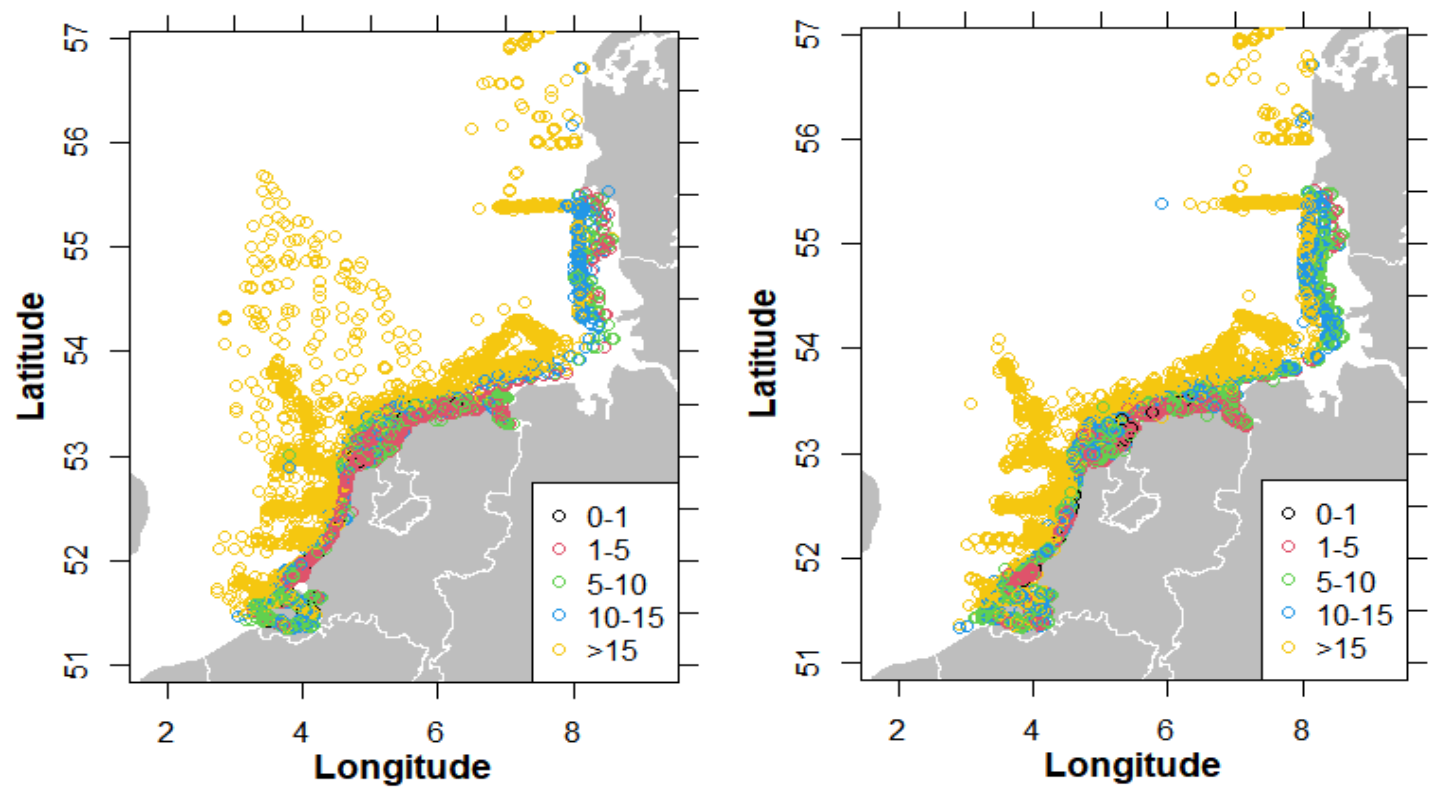

Figuur b 12 De ruimtelijke verspreiding van alle station opgedeeld op basis van de gemeten waterdiepte op het moment van bemonsteren. Links kwartaal 1 en 2 en rechts Kwartaal 3 en 4.

In totaal werden 5.353 tarbot en 3.402 griet geregistreerd. In dezelfde vangst werden daarentegen 2.884.136 schol en 2.859.235 schar geregistreerd. Niet alleen in de vooroever is de abundantie van 
tarbot en griet dus laag. Een trek (DFS 1984) met in totaal 771 tarbot, waarvan 768 met een lengte tussen 4-6 cm, is een enorme uitschieter en daarmee twijfelachtig. Deze is uit verdere analyses verwijderd.

De lengteverdeling van beide soorten was $18 \mathrm{~mm}$ tot $550 \mathrm{~mm}$ (Figuur b 13), de grotere vissen worden met deze tuigen met kleine maaswijdte en beperkte vissnelheid niet gevangen. De verdeling van de aantallen per lengte per kwartaal zijn een weergave van de uitgevoerde bemonstering, meer trekken in het derde en vierde kwartaal, en de locatie, bijv. geen strandbemonstering in het vierde kwartaal. $\mathrm{Er}$ is geen directe biologische interpretatie te maken op basis van deze gegevens.
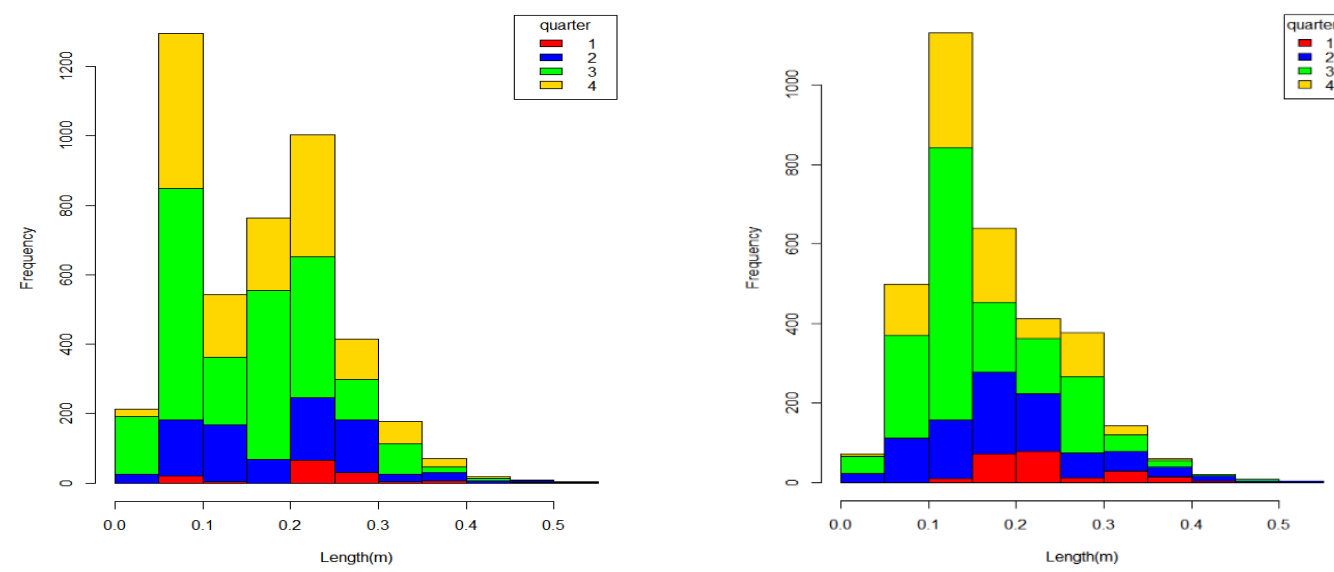

Figuur b 13 De lengtefrequentie van tarbot (rechts) en griet (links) per kwartaal.

Ook de ruimtelijke verspreiding van de waarnemingen geeft op de eerste plaats de invloed van de verschillende bemonsteringen weer. Toch is daaruit wel enig beeld te halen, namelijk dat beide soorten langs de gehele Nederlandse kust maar ook verder noordwaarts werden aangetroffen (Figuur b 14, Figuur b 15). Daarnaast dat met name tarbot beperkt gevangen wordt in de Waddenzee en dat tarbot ten opzichte van griet beperkter wordt gevangen in de Scheldes.

Griet werd in Q1 \& Q2 in 4,6-9,1\% van de trekken waargenomen, juveniele griet $(<14 \mathrm{~cm})$ werd vooral gevangen in de trekken in de 0-5 $\mathrm{m}$ zone in de diepere zones werden ze in minder dan $1 \%$ van de trekken aangetroffen (Tabel B 1). De percentages in Q3 \& Q4 zijn wat hoger maar laten een vergelijkbaar beeld zien. De gegevens van tarbot laten hetzelfde beeld zien met juveniele trekken in de ondiepste zone 0-5 m. Juveniele schol die in een veel groter percentage van de trekken werd aangetroffen, werd duidelijk in beide delen van het jaar in een veel lager percentage aangetroffen in de trekken dieper dan15 m. In Q1 \& Q2 is ook voor juveniele schol een voorkeur voor de $0-5 \mathrm{~m}$ zichtbaar.
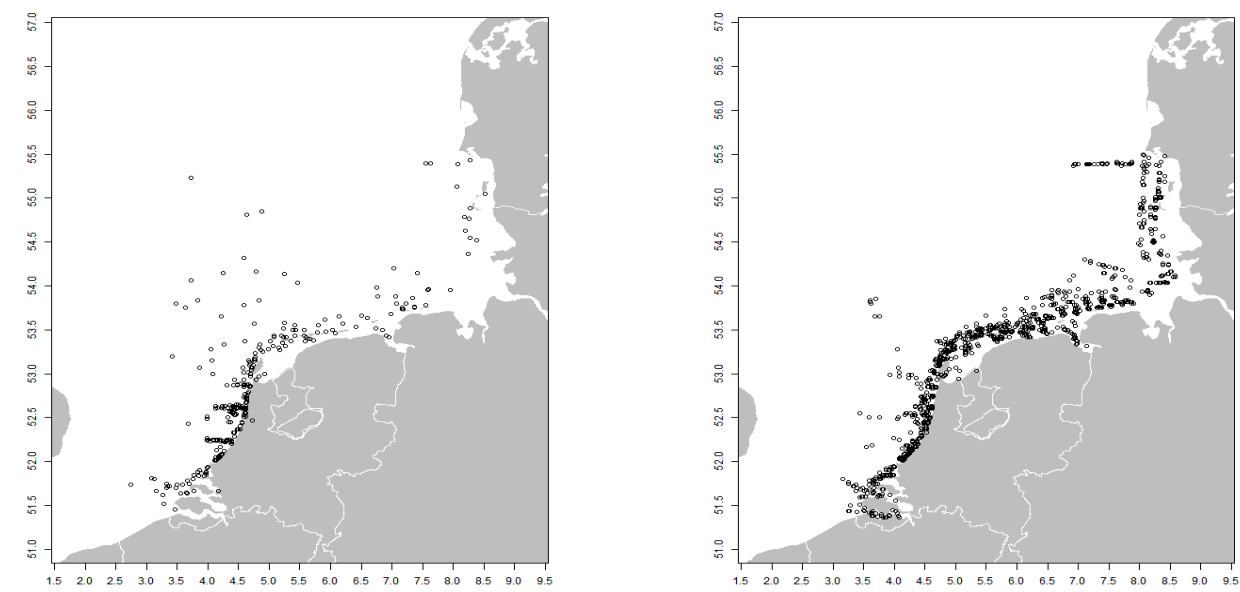

Figuur b 14 De vistrekken waarin tarbot werd geregistreerd in kwartaal 1 \&2 (links) en in kwartaal 3 \& 4 (Rechts). Te vergelijken met de totaalaantal uitgevoerde trekken zoals weergegeven in Figuur b 12. 

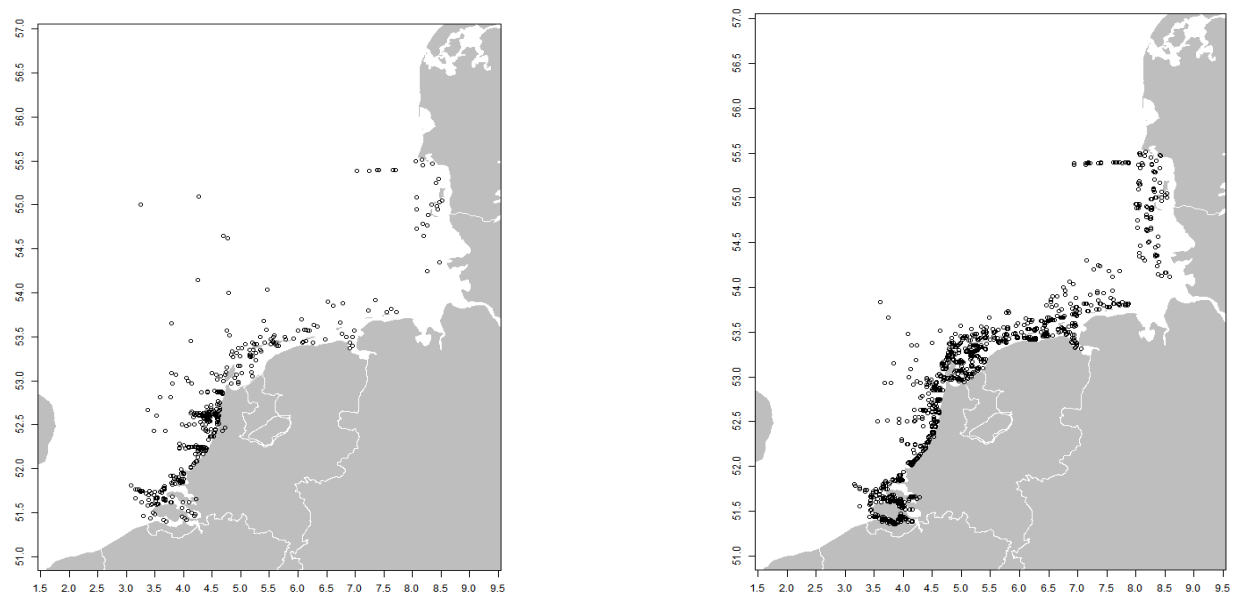

Figuur b 15 De vistrekken waarin griet werd geregistreerd in kwartaal 1 \& 2 (links) en in kwartaal 3 \& 4 (Rechts). Te vergelijken met de totaalaantal uitgevoerde trekken zoals weergegeven in Figuur $b 12$.

Tabel $B 1$ Bovenste deel van de tabel kwartaal 1 \& 2; onderste deel kwartaal 3\&4. Totaalaantal trekken van de verschillende programma's tezamen. Het percentage van het aantal trekken per diepteklasse waarin de betreffende soort is aangetroffen.

\begin{tabular}{l|c|cc|cc|cc} 
Diepte & Aantal trekken totaal & \% griet & \%griet $<14 \mathrm{~cm}$ & \% tarbot & \%tarbot $<14 \mathrm{~cm}$ & \% schol & \%schol < $7 \mathrm{~cm}$ \\
\hline $0-1$ & 325 & 4.6 & 3.7 & 16.9 & 16.6 & 54.8 & 44.9 \\
$1-5$ & 1234 & 9.1 & 3.4 & 11.1 & 5.8 & 87.4 & 51.6 \\
$5-10$ & 1768 & 7.9 & 1.9 & 4.7 & 1.1 & 86.0 & 33.3 \\
$10-15$ & 1407 & 6.7 & 0.6 & 4.4 & 0.3 & 75.8 & 15.8 \\
$>15$ & 3249 & 7.2 & 0.2 & 4.9 & 0.1 & 67.0 & 3.4 \\
Diepte & Aantal trekken totaal & \% griet & \%griet <14cm & \% tarbot & \%tarbot <18cm & \% schol & \%schol <10cm \\
\hline $0-1$ & 161 & 18.6 & 17.4 & 16.8 & 16.1 & 46.6 & 46.0 \\
$1-5$ & 3302 & 11.3 & 7.4 & 9.1 & 5.4 & 91.9 & 85.5 \\
$5-10$ & 6334 & 8.2 & 3.7 & 7.5 & 3.7 & 94.2 & 83.4 \\
$10-15$ & 3964 & 4.9 & 1.2 & 6.1 & 1.3 & 85.7 & 67.0 \\
$>15$ & 6159 & 5.6 & 0.4 & 7.1 & 0.6 & 67.2 & 32.5
\end{tabular}




\section{Bijlage 10 Vangstefficiëntie $2 \mathrm{~m}$ boomkor}

Om de totale dichtheid 0-groep schol in de brandingszone te schatten kan gecorrigeerd worden voor de efficiëntie van het gebruikte vistuig. Tijdens de strandbemonstering ter hoogte van IJmuiden in 2020 is er gevist met een $2 \mathrm{~m}$ boomkor met één wekkerketting en $10 \mathrm{~mm}$ maaswijdte en er is gevist met een $2 \mathrm{~m}$ boomkor met één wekkerketting en $20 \mathrm{~mm}$ maaswijdte net. De gebruikte vistuigen zijn daarmee in de basis vergelijkbaar met het vistuig dat is gebruikt in de onderzoeken van Kuipers (1975) en Dapper (1978) op de wadplaten van het Balgzand ( $2 \mathrm{~m}$ boomkor, één wekkerketting en $10 \mathrm{~mm}$ maaswijdte), alhoewel de gebruikte $20 \mathrm{~mm}$ maaswijdte van een van de gebruikte vistuigen hierbij wel degelijk afwijkt. Vanwege het ontbreken van efficiëntie schattingen voor een $20 \mathrm{~mm}$ (gestrekt) maaswijdte net, wordt in de opwerking ook voor deze maaswijdte uitgegaan van de efficiëntie berekeningen van Kuipers (1975) en Dapper (1978). Als gevolg van het gebruik van een grotere maaswijdte zijn de kleinste lengte klassen in geringe aantallen gevangen, de dichtheidsschattingen van deze kleinste lengte klassen schol $(1-5 \mathrm{~cm})$ zullen daardoor een onderschatting zijn in de huidige opwerking.

Kuipers (1978) kwam tot de conclusie dat de totale efficiëntie het resultaat is van twee factoren, namelijk verstoring veroorzaakt door de boot (Ed) en zijwaartse ontsnapping (EI). Er werd door Kuipers (1978) geen bewijs gevonden van ontsnapping onder het net door, wellicht het gevolg van het feit dat op vlakke wadplaten gevist werd waar het vistuig gemakkelijk in het sediment zakt. De efficiëntie als gevolg van de verstoring van de boot kan vervolgens als volgt worden berekend (formule opnieuw afgeleid door Aarts et al. 2019):

$$
E_{d} \quad<-\exp (1.2263863-0.6000988 * \operatorname{Ln}(L))
$$

Hierbij is de efficiëntie als gevolg van verstoring door de boot ( $\left.E_{d}\right)$ een functie van lengte $(L)$. De efficiëntie als gevolg van zijwaartse ontsnapping $\left(E_{l}\right)$ was door Kuipers (1975) geschat aan de hand van de vangsten van een $2 \mathrm{~m}$-boomkor in vergelijking met die van twee aan elkaar gemonteerde $2 \mathrm{~m}$ boomkorren. De efficiëntie als gevolg van zijwaartse ontsnapping kon daarmee berekend worden als functie van lengte $(L)$ via een aantal vergelijkingen (vergelijkingen opnieuw afgeleid door Aarts et al. 2019). De vangst ratio van de $2 \mathrm{~m}$-boomkor relatief aan de dubbele $2 \mathrm{~m}$-boomkor wordt als volgt beschreven:

$$
\operatorname{Rc}(L) \quad<-\exp (0.7334693-0.4834846 * \operatorname{Ln}(L))
$$

De onderliggende gedachten achter de zijwaartse ontsnapping is dat binnen een vaste breedte (b) aan beide kanten van het net vis ontsnapt, hierbij is de breedte (b) waarbinnen vis ontsnapt een functie van lengte (L). Voor grotere (plat)vis is deze breedte (b) ook groter vanwege de hogere zwemsnelheid van grotere vis. De breedte (b) waarbinnen (plat)vis aan beide kanten van de boomkor kan ontsnappen als functie van lengte $(L)$ kan geschat worden voor een boomkor met dimensie a via de volgende vergelijking:

$$
\mathrm{b}(\mathrm{L}) \quad<-\frac{a\left(1-\frac{1}{2} *\left(\frac{2}{R c(L)}\right)\right)}{\left(1-\left(\frac{2}{R c(L)}\right)\right.}
$$

De efficiëntie als gevolg van de zijwaartse ontsnapping ( $\left.E_{1}\right)$ als functie van lengte kan vervolgens worden berekend, waarin in deze opwerking voor a de breedte van het gebruikte vistuig is gebruikt.

$$
\mathrm{E}_{\mathrm{l}} \quad<-\frac{a-2 b(L)}{a}
$$


Ook hierbij is de vergelijking enkel toepasbaar op schol groter dan $5 \mathrm{~cm}$. De totale efficiëntie van de $2 \mathrm{~m}$ boomkor met één wekkerketting en $10 \mathrm{~mm}$ maaswijdte is daarmee een functie van zowel verstoring als zijwaartse ontsnapping en kan voor schol groter dan $5 \mathrm{~cm}$ berekend worden als volgt:

$$
\mathrm{E} \quad<-\mathrm{E}_{\mathrm{d}} * \mathrm{E}_{\mathrm{l}}
$$

Voor schol kleiner dan $5 \mathrm{~cm}$ wordt aangenomen dat de net efficiëntie $100 \%$ is, afgezien van de ontsnapping door de mazen heen. Kuipers (1975) heeft daarom voor deze kleinste schol per halve centimeter klassen de maaswijdte efficiëntie van het gebruikte vistuig bepaald aan de hand van een selectie factor. De vangstefficiëntie van schol per lengte klassen op basis van Kuipers (1975) zijn experimenten is te vinden in Tabel B 2. In aanvulling stelde Dapper (1978) dat het resultaat van de maaswijdte proeven de geschatte netefficiëntie voor schol kleiner dan $5 \mathrm{~cm}$ door Kuipers (1975) bijgesteld kon worden voor de dichtheidsbepalingen. Dapper (1978) heeft de maaswijdte efficiëntie van de gebruikte maaswijdte $(10 \mathrm{~mm})$ bepaald aan de hand van de ontsnapping van schol door de mazen van het net. De lengte afhankelijke selectiviteit van de maaswijdte $(10 \mathrm{~mm})$ op basis van deze experimenten is te vinden in Tabel B 2 en is dus een verfijning van de maaswijdte efficiëntie schattingen van Kuipers (1975). De totale efficiëntie (Tabel B 2) als functie van lengte is daarmee een combinatie van de resultaten van Kuipers (1975) en Dapper (1978), waarbij de efficiëntie voor schol kleiner dan $5 \mathrm{~cm}$ wordt bepaald aan de hand van de ontsnappen door de mazen van het net en voor schol groter dan $5 \mathrm{~cm}$ aan de hand van verstoring door de boot en zijwaartse ontsnapping (Figuur $b$ $17)$.

De aantallen 0-groep schol gevangen tijdens de strandbemonstering in 2020 ter hoogte van IJmuiden zijn gebruikt om de ongecorrigeerde en gecorrigeerde dichtheden per $1000 \mathrm{~m}^{2}$ met elkaar te vergelijken. In de ongecorrigeerde opwerking wordt aan de hand van bevist oppervlakte (trekafstand $x$ breedte vistuig) het aantal gevangen schol per trek opgewerkt naar aantal per $1000 \mathrm{~m}^{2}$. Piek dichtheden werden aangetroffen eind mei, en na juni werd er nauwelijks nog schol gevangen in de brandingszone (Figuur b 16). De gecorrigeerde dichtheden op basis van de lengte afhankelijke net- en maaswijdte efficiëntie van 0-groep schol laten vrijwel dezelfde dichtheden als hetzelfde dichtheidsverloop door her jaar heen zien (Figuur b 16).

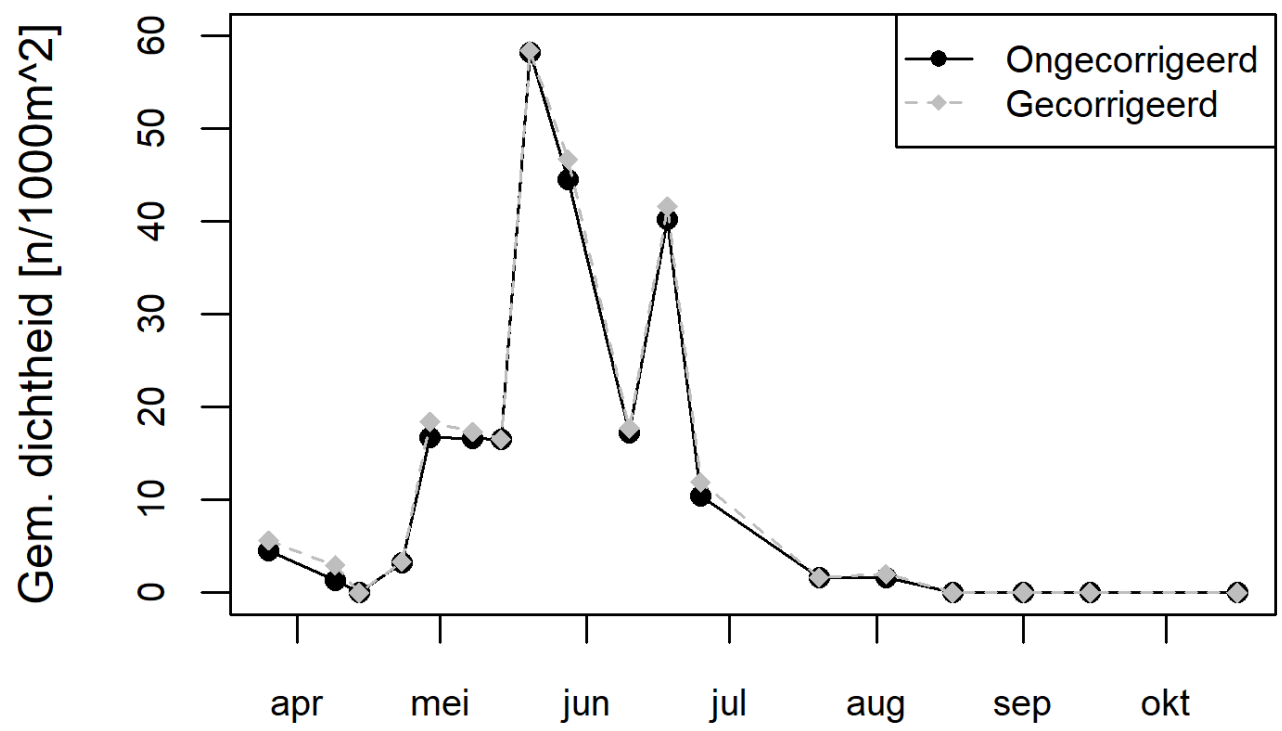

\section{Datum}

Figuur b 16 Seizoen dynamiek in de gemiddelde dichtheid juveniele schol in de brandingszone van IJmuiden in 2020. Links: de ongecorrigeerde vangsten (zwarte doorgetrokken lijn) en de vangsten gecorrigeerd voor zowel net-als maaswijdte- efficiëntie (grijze stippellijn). Rechts: de ongecorrigeerde vangsten (zwarte doorgetrokken lijn) en de vangsten gecorrigeerd voor een combinatie van Kuipers (1975) en Dapper (1978).

Dat de gecorrigeerde dichtheden weinig verschillen met de ongecorrigeerde komt doordat in de 2020 strandbemonstering bij IJmuiden geringe aantallen schol kleiner dan $3 \mathrm{~cm}$ gevangen zijn, maar ook vanwege het ontbreken van schol in de vangsten na juni. De eerst bemonsteringsdagen was er enkel 
gevist met $20 \mathrm{~mm}$ maaswijdte, een te grote maaswijdte om de allerkleinste schol te vangen. Pas begin mei is er ook met $10 \mathrm{~mm}$ maaswijdte gevist, de meeste schol had toen al een lengte groter dan 2,5 cm. De meest schol die eind juni werden gevangen hadden op dat moment een lengte rond de 6 $\mathrm{cm}$. Vanaf deze lengte neemt de totale efficiënte van het gebruikte tuig voor schol weer af, echter is na juni nauwelijks meer 0-groep schol aangetroffen in de brandingszone.

\section{Vangst efficientie Boomkor}

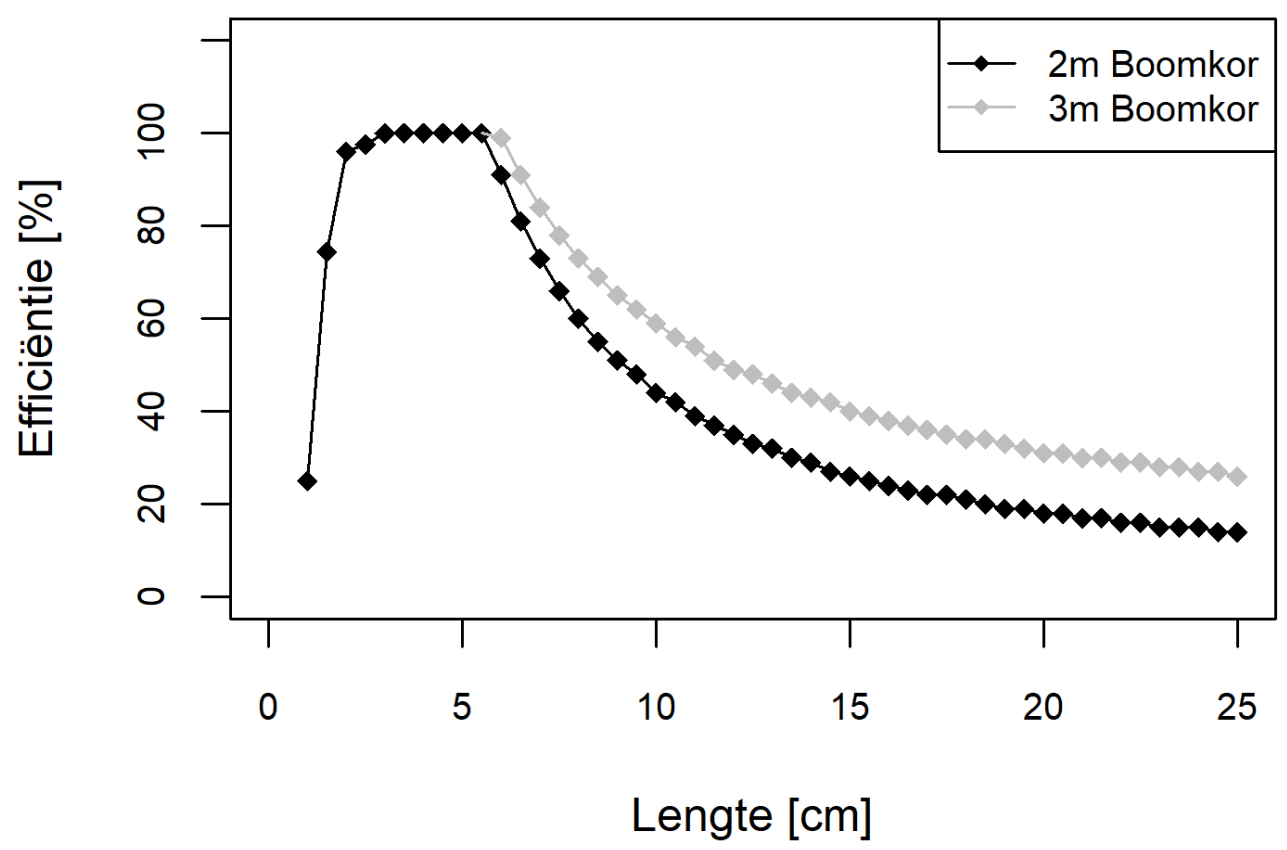

Figuur b 17 Totale vangst efficiëntie van de $2 \mathrm{~m}$ boomkor (zwart) en $3 \mathrm{~m}$ boomkor (grijs) op basis van net efficiëntie zoals in Kuipers (1975) en maaswijdte efficiëntie zoals in Dapper (1978) als functie van lengte. Voor schol groter dan $5 \mathrm{~cm}$ zijn de formules zoals afgeleid in Aarts e.a. 2019 gebruikt, voor schol van $5 \mathrm{~cm}$ en kleiner zijn de maaswijdte efficiëntie schattingen van Dapper (1978) gebruikt.

Tabel B 2 Vangstefficiëntie van de $2 \mathrm{~m}$ boomkor met één wekkerketting en $10 \mathrm{~mm}$ maaswijdte. Net efficiëntie zoals in Kuipers (1975) en maaswijdte efficiëntie zoals in Dapper (1978) en de totale efficiëntie (\%) als functie van lengte. Hierbij is de berekende maaswijdte efficiëntie van Dapper (1978) een verfijning van de door Kuipers (1975) geschatte efficiëntie voor schol kleiner dan $5 \mathrm{~cm}$.

\begin{tabular}{|l|c|c|c|}
\cline { 2 - 4 } \multicolumn{1}{c|}{} & Kuipers, 1975 & Dapper, 1978 & Gecombineerd \\
\cline { 2 - 4 } Lengte $(\mathrm{mm})$ & Net efficiëntie (\%) & Maaswijdte efficiëntie (\%) & Totale Efficiëntie (\%) \\
\hline $6-10$ & 5 & 25 & 25 \\
\hline $11-15$ & 5 & 74.4 & 74.4 \\
\hline $16-20$ & 15 & 96 & 96 \\
\hline $21-25$ & 50 & 97.6 & 97.6 \\
\hline $26-30$ & 85 & 100 & 100 \\
\hline $31-35$ & 95 & 100 & 100 \\
\hline 40 & 100 & 100 & 100 \\
\hline 45 & 100 & 100 & 100 \\
\hline 50 & 100 & 100 & 100 \\
\hline
\end{tabular}




\section{Bijlage 11 Modelbeschrijving DEB}

Het model is identiek aan het eerder beschreven model door (Teal e.a., 2012). Het model bevat temperatuur- en lichaamsgrootteafhankelijke functies voor het verwerven en toewijzen van energie. Het model voorspelt individuele groei vanaf de initiële grootte in relatie tot tijd $t$. We geven hieronder een korte beschrijving van de opgenomen processen en een overzicht van de modelvergelijkingen in Tabel B 3, voor de theoretische onderbouwing van het model verwijzen we naar (Teal e.a., 2012) en (van der Veer e.a., 2009).

Veranderingen in lichaamsvolume $\mathrm{V}$ in de tijd zijn afhankelijk van de fractie van energie gebruikt voor groei $\kappa$, het voedingniveau $\mathrm{F}$, de maximale oppervlakte-specifieke assimilatiesnelheid $\left\{\dot{p}_{a m}\right\}$, de enzymkinetiek $F r$, de volume-specifieke onderhoudskosten $\left[p_{m}\right]$, de Arrhenius schalingscoëfficiënt $\mathrm{k}_{T}$, de maximale opslagdichtheid $\left[E_{m}\right]$ en de volume-specifieke kosten voor weefsel $\left[E_{G}\right]$. De lengtevolumerelatie is een schaalfunctie die afhangt van de vormcoëfficiënt $m$. De Arrheniusschaalcoëfficiënt is afhankelijk van de temperatuur T, en de referentie T_ref en Arrhenius T_A temperaturen.

De enzymkinetiek verschilt tussen schol en tong in een enkele term, die de temperatuurafhankelijkheid van de enzymkinetiek van schol enigszins herschaalt in vergelijking met tong. De enzymkinetiek van beide soorten hangt af van de huidige temperatuur in relatie tot de referentietemperatuur, de bovenste $\mathrm{T} \_\mathrm{H}$ - en onderste $\mathrm{T} \_\mathrm{L}-\mathrm{grenzen}$ van het temperatuurtolerantiebereik en de snelheid van afname bij de bovenste T_AH- en onderste T_ALgrenzen van het tolerantiebereik.

We definiëren soortspecifieke parameters voor schol (Tabel B 4) en tong (Tabel B 5). Er werden groeivoorspellingen berekend voor het groeiseizoen, dat verschilt tussen de twee soorten en binnen de soorten tussen de verschillende leeftijdsklassen. Voor schol A0 gaan we ervan uit dat het groeiseizoen loopt van 16 april tot 16 augustus. De gemiddelde dag waarop de schollarven in de Noordzee zich het meest vestigen, ligt rond dag 105, ofwel 16 april (Teal e.a., 2008). Het einde van het groeiseizoen is gebaseerd op de waargenomen afname van de groei in de Noordzee van schol A0, waarvan wordt aangenomen dat deze het gevolg is van een afname van de voedselbeschikbaarheid rond die tijd (Teal e.a., 2012; Ciotti e.a., 2014). Voor schol A1 hebben we geen informatie gevonden over de start van het groeiseizoen en gaan er daarom van uit dat de groei op dezelfde dag begint als voor tong, namelijk 1 mei. Het einde van het groeiseizoen is voor schol A1 dezelfde dag als voor schol A0, 16 augustus. Voor tong A0 gaan we ervan uit dat het groeiseizoen loopt van 3 juli tot 28 oktober. De gemiddelde dag van vestiging van tonglarven in de Noordzee ligt rond dag 183, of 3 juli (Teal e.a., 2008). Het einde van het groeiseizoen is later dan voor schol aangezien de voedselbeschikbaarheid voor tong waarschijnlijk constanter is dan voor schol (Teal e.a., 2012), otolieten studies tonen aan dat de groei van tong stopt na oktober (Millner en Whiting, 1996). Voor tong A1 wordt aangenomen dat het groeiseizoen rond 1 mei begint en eind oktober stopt, op basis van otolietenstudies van verschillende leeftijden van tong (Millner en Whiting, 1996).

We lossen de gewone differentiaalvergelijking voor groei (Tabel B 3) voor schol en tong op voor individuen van leeftijd 0 en 1 tijdens het groeiseizoen. Het model wordt gestart met verschillende lengtes aan het begin van het seizoen, die afhankelijk zijn van de leeftijd van de individuen.

Optimale groeiomstandigheden voor schol en tong

De groeisnelheid ( $\mathrm{dV} / \mathrm{dt}$ ) is zowel temperatuur- als lengteafhankelijk. De temperatuur- en lengteafhankelijkheid van de groeisnelheid, voorspeld voor de twee sets parameters voor schol en tong, is uitgezet in Figuur b 18. Hier zien we dat beide soorten optimaal groeien bij tussenliggende temperaturen. Optimale groeiomstandigheden verschuiven naar een lagere temperatuur met toenemende lengte, of grotere individuen zijn minder tolerant voor temperatuur. Terwijl schol over het 
algemeen niet kan groeien bij temperaturen $>25{ }^{\circ} \mathrm{C}$, kan tong wel groeien bij $30^{\circ} \mathrm{C}$. Tong is met andere woorden beter bestand tegen hoge temperaturen dan schol.

Tabel B 3 DEB-model gebruikt voor de groeiberekeningen van tong en schol, zoals eerder gedefinieerd in Teal et al. (2012). Merk op dat voor tong en schol verschillende formuleringen voor de enzymkinetiek worden gebruikt.

\begin{tabular}{|c|c|}
\hline Beschrijving & Functie \\
\hline $\begin{array}{l}\text { Volume-lengte } \\
\text { relatie }\end{array}$ & $V(L)=m L^{3}$ \\
\hline $\begin{array}{l}\text { Arrhenius } \\
\text { schalingscoefficient }\end{array}$ & $\mathrm{k}_{T}=\exp \left(\frac{T_{A}}{T_{r e f}}-\frac{T_{A}}{T}\right)$ \\
\hline $\begin{array}{l}\text { Enzymkinetiek } \\
\text { Schol }\end{array}$ & $F r_{P}=\mathrm{k}_{T}\left(\frac{1+\exp \left(\frac{T_{A L}}{T_{r e f}}-\frac{T_{A L}}{T_{L}}\right)+\exp \left(\frac{T_{A H}}{T_{H}-0.1 L}-\frac{T_{A H}}{T_{r e f}}\right)}{1+\exp \left(\frac{T_{A L}}{T}-\frac{T_{A L}}{T_{L}}\right)+\exp \left(\frac{T_{A H}}{T_{H}-0.1 L}-\frac{T_{A H}}{T}\right)}\right)$ \\
\hline $\begin{array}{l}\text { Enzymkinetiek } \\
\text { Tong }\end{array}$ & $F r_{S}=\mathrm{k}_{T}\left(\frac{1+\exp \left(\frac{T_{A L}}{T_{r e f}}-\frac{T_{A L}}{T_{L}}\right)+\exp \left(\frac{T_{A H}}{T_{H}}-\frac{T_{A H}}{T_{r e f}}\right)}{1+\exp \left(\frac{T_{A L}}{T}-\frac{T_{A L}}{T_{L}}\right)+\exp \left(\frac{T_{A H}}{T_{H}}-\frac{T_{A H}}{T}\right)}\right)$ \\
\hline Groei & $\frac{d V}{d a}=\frac{\kappa F\left\{\dot{p}_{a m}\right\} F r V^{2 / 3}-\left[p_{m}\right] \mathrm{k}_{T} V}{\kappa F\left[E_{m}\right]+\left[E_{G}\right]}$ \\
\hline Symbool & Beschrijving \\
\hline$T$ & Temperatuur [Kelvin] \\
\hline$V$ & Volume $\left[\mathrm{cm}^{3}\right]$ \\
\hline$L$ & Lengte $[\mathrm{cm}]$ \\
\hline
\end{tabular}

Tabel B 4 Standaard parameterwaarden voor schol en verwijzing naar referenties voor afleiding van de waarden.

\begin{tabular}{|c|c|c|c|}
\hline Symbool & Beschrijving & Waarde en unit & Referentie(s) \\
\hline \multicolumn{4}{|c|}{ Beginwaarden } \\
\hline$L_{0}$ & $\begin{array}{l}\text { Lengte aan de start van het } \\
\text { groeiseizoen }\end{array}$ & $11 \mathrm{~cm}-$ Leeftijd 1 & $\begin{array}{l}\text { Lengte start van de groei (Russell } \\
\text { 1976, Teal et al. 2012) } \\
\text { Lengte aan het einde van de zomer } \\
\text { (van Keeken et al. 2004) }\end{array}$ \\
\hline \multirow[t]{2}{*}{$d_{0}$} & \multirow[t]{2}{*}{$\begin{array}{l}\text { Dag van het jaar waarop de groei } \\
\text { start (settlement) }\end{array}$} & $105-$ Leeftijd 0 & $\begin{array}{l}\text { Piek in vestiging rond } 16 \text { april (Teal et } \\
\text { al. 2008) }\end{array}$ \\
\hline & & $120-$ Leeftijd 1 & $\begin{array}{l}1 \text { Mei gebaseerd op het groei seizoen } \\
\text { van mei-oktober voor een range aan } \\
\text { leeftijden (Millner and Whiting 1996). }\end{array}$ \\
\hline$d_{e}$ & Laatste dag van groeiseizoen & $227-$ Leeftijd 0 & $\begin{array}{l}16 \text { Augustus minder voedsel } \\
\text { beschikbaar (Teal et al. 2012) en } \\
\text { verlate groei tot aan het einde van } \\
\text { Augustus (Ciotti et al. 2014) }\end{array}$ \\
\hline
\end{tabular}




\begin{tabular}{|c|c|c|c|}
\hline & & 227 - Leeftijd 1 & Het zelfde genomen als voor leeftijd 0 . \\
\hline \multicolumn{4}{|c|}{ Modelparameters } \\
\hline$F$ & Voedingsniveau & 0.9 & (Teal et al. 2012) \\
\hline$m$ & Vormcoëfficiënt & 0.219 & $\begin{array}{l}\text { (van der Veer et al. 2009, Teal et al. } \\
\text { 2012) }\end{array}$ \\
\hline$T_{A}$ & Arrhenius temperatuur & $7000 \mathrm{~K}$ & $\begin{array}{l}\text { (van der Veer et al. 2009, Teal et al. } \\
2012 \text { ) }\end{array}$ \\
\hline$T_{\text {ref }}$ & Referentie temperatuur kinetiek & $283 \mathrm{~K}$ & $\begin{array}{l}\text { (van der Veer et al. 2009, Teal et al. } \\
\text { 2012) }\end{array}$ \\
\hline$T_{A L}$ & Afnamesnelheid bij ondergrens & $50000 \mathrm{~K}$ & $\begin{array}{l}\text { (van der Veer et al. 2009, Teal et al. } \\
\text { 2012) }\end{array}$ \\
\hline$T_{L}$ & Ondergrens van tolerantiebereik & $277 \mathrm{~K}$ & $\begin{array}{l}\text { (van der Veer et al. 2009, Teal et al. } \\
\text { 2012) }\end{array}$ \\
\hline$T_{A H}$ & Afnamesnelheid bij bovengrens & $100000 \mathrm{~K}$ & $\begin{array}{l}\text { (van der Veer et al. 2009, Teal et al. } \\
\text { 2012) }\end{array}$ \\
\hline$T_{H}$ & Bovengrens van tolerantiebereik & $297 \mathrm{~K}$ & $\begin{array}{l}\text { (van der Veer et al. 2009, Teal et al. } \\
\text { 2012) }\end{array}$ \\
\hline$\left\{\dot{p}_{a m}\right\}$ & $\begin{array}{l}\text { Maximale oppervlaktespecifieke } \\
\text { assimilatiesnelheid }\end{array}$ & $390 \mathrm{~J} \mathrm{~cm}^{-2} \mathrm{~d}^{-1}$ & $\begin{array}{l}\text { (van der Veer et al. 2009, Teal et al. } \\
2012 \text { ) }\end{array}$ \\
\hline$\left[p_{m}\right]$ & $\begin{array}{l}\text { Volumespecifieke } \\
\text { onderhoudskosten }\end{array}$ & $19.4 \mathrm{~J} \mathrm{~cm}^{-3} \mathrm{~d}^{-1}$ & $\begin{array}{l}\text { (van der Veer et al. 2009, Teal et al. } \\
\text { 2012) }\end{array}$ \\
\hline$\left[E_{m}\right]$ & Maximale opslagdichtheid & $2500 \mathrm{~J} \mathrm{~cm}^{-3}$ & $\begin{array}{l}\text { (van der Veer et al. 2009, Teal et al. } \\
2012 \text { ) }\end{array}$ \\
\hline$\left[E_{G}\right]$ & $\begin{array}{l}\text { Volumespecifieke kosten van } \\
\text { structuur }\end{array}$ & $5600 \mathrm{~J} \mathrm{~cm}^{-3}$ & $\begin{array}{l}\text { (van der Veer et al. 2009, Teal et al. } \\
2012 \text { ) }\end{array}$ \\
\hline$\kappa$ & $\begin{array}{l}\text { Fractie van verbruikte energie } \\
\text { besteed aan onderhoud plus groei }\end{array}$ & 0.85 & $\begin{array}{l}\text { (van der Veer et al. 2009, Teal et al. } \\
2012 \text { ) }\end{array}$ \\
\hline
\end{tabular}

Tabel B 5 Standaard parameterwaarden voor tong en verwijzing naar referenties voor afleiding van de waarden.

\begin{tabular}{|c|c|c|c|}
\hline Symbool & Beschrijving & Waarde en unit & Referentie(s) \\
\hline \multicolumn{4}{|c|}{ Initiële waarden } \\
\hline \multirow[t]{2}{*}{$L_{0}$} & $\begin{array}{l}\text { Lengte aan de start van het } \\
\text { groeiseizoen }\end{array}$ & $1.2 \mathrm{~cm}-$ Age 0 & \multirow[t]{2}{*}{$\begin{array}{l}\text { Lengte start groeiseizoen (Russell 1976, } \\
\text { Teal et al. 2012) }\end{array}$} \\
\hline & & $12 \mathrm{~cm}-$ Age 1 & \\
\hline$d_{0}$ & & 183 - Age 0 & Piek in vestiging 3 juli (Teal et al. 2008) \\
\hline
\end{tabular}




\begin{tabular}{|c|c|c|c|}
\hline & $\begin{array}{l}\text { Dag van het jaar waarop de } \\
\text { groei start (settlement) }\end{array}$ & $120-$ Age 1 & $\begin{array}{l}1 \text { mei groeiseizoen mei - oktober voor een } \\
\text { range aan leeftijden (Millner and Whiting } \\
1996 \text { ) }\end{array}$ \\
\hline$d_{e}$ & Laatste dag van groeiseizoen & 300 - Age 0, Age 1 & $\begin{array}{l}28 \text { oktober voedselbeschikbaarheid } \\
\text { constanter dan voor schol (Teal et al. } \\
2012 \text { ) groeiseizoen mei - oktober voor een } \\
\text { range aan leeftijden (Millner and Whiting } \\
\text { 1996) }\end{array}$ \\
\hline \multicolumn{4}{|c|}{ Modelparameters } \\
\hline$F$ & Voedingsniveau & 0.6 & (Teal et al. 2012) \\
\hline$m$ & Vormcoëfficiënt & 0.192 & (Freitas et al. 2010, Teal et al. 2012) \\
\hline$T_{A}$ & Arrhenius temperatuur & $8500 \mathrm{~K}$ & (Freitas et al. 2010, Teal et al. 2012) \\
\hline$T_{\text {ref }}$ & $\begin{array}{l}\text { Referentie temperatuur } \\
\text { kinetiek }\end{array}$ & $293 \mathrm{~K}$ & (Freitas et al. 2010, Teal et al. 2012) \\
\hline$T_{A L}$ & $\begin{array}{l}\text { Afnamesnelheid bij } \\
\text { ondergrens }\end{array}$ & $50000 \mathrm{~K}$ & (Teal et al. 2012) \\
\hline$T_{L}$ & $\begin{array}{l}\text { Ondergrens van } \\
\text { tolerantiebereik }\end{array}$ & $282 \mathrm{~K}$ & (Fonds 1979, Teal et al. 2012) \\
\hline$T_{A H}$ & $\begin{array}{l}\text { Afnamesnelheid bij } \\
\text { bovengrens }\end{array}$ & $100000 \mathrm{~K}$ & (Teal et al. 2012) \\
\hline$T_{H}$ & $\begin{array}{l}\text { Bovengrens van } \\
\text { tolerantiebereik }\end{array}$ & $305 \mathrm{~K}$ & (Fonds 1979, Teal et al. 2012) \\
\hline$\left\{\dot{p}_{a m}\right\}$ & $\begin{array}{l}\text { Maximale } \\
\text { oppervlaktespecifieke } \\
\text { assimilatiesnelheid }\end{array}$ & $864 \mathrm{~J} \mathrm{~cm}^{-2} \mathrm{~d}^{-1}$ & (Freitas et al. 2010, Teal et al. 2012) \\
\hline$\left[p_{m}\right]$ & $\begin{array}{l}\text { Volumespecifieke } \\
\text { onderhoudskosten }\end{array}$ & $54.1 \mathrm{~J} \mathrm{~cm}^{-3} \mathrm{~d}^{-1}$ & (Freitas et al. 2010, Teal et al. 2012) \\
\hline$\left[E_{m}\right]$ & Maximale opslagdichtheid & $1986 \mathrm{~J} \mathrm{~cm}^{-3}$ & (Freitas et al. 2010, Teal et al. 2012) \\
\hline$\left[E_{G}\right]$ & $\begin{array}{l}\text { Volumespecifieke kosten van } \\
\text { structuur }\end{array}$ & $5600 \mathrm{~J} \mathrm{~cm}^{-3}$ & (Freitas et al. 2010, Teal et al. 2012) \\
\hline$\kappa$ & $\begin{array}{l}\text { Fractie van verbruikte energie } \\
\text { besteed aan onderhoud plus } \\
\text { groei }\end{array}$ & 0.9 & (Freitas et al. 2010, Teal et al. 2012) \\
\hline
\end{tabular}



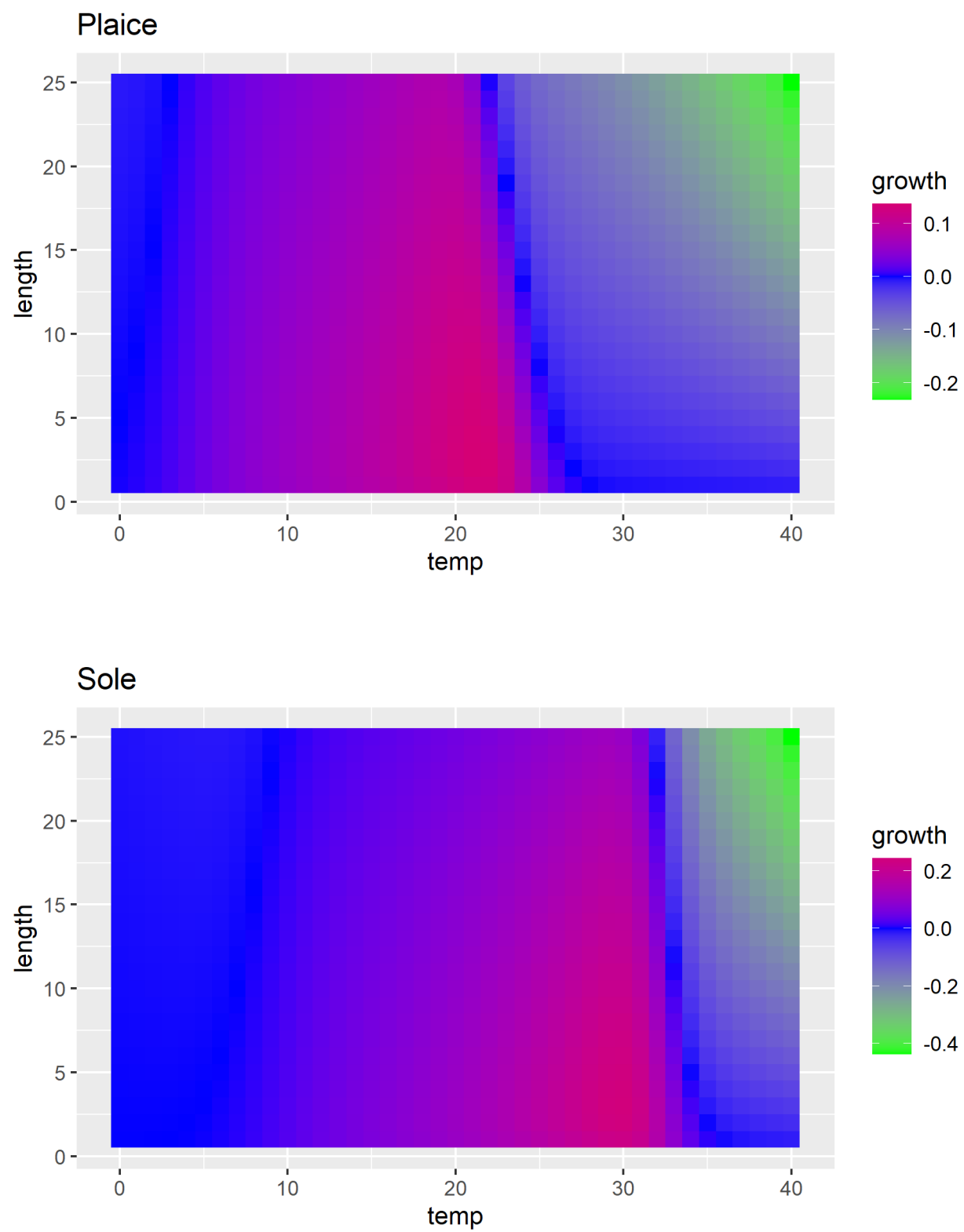

Figuur b 18 Groeivoorspellingen (in $\mathrm{cm} / \mathrm{dag}$ ) voor verschillende lengtes en temperaturen. Boven schol, onder tong. 

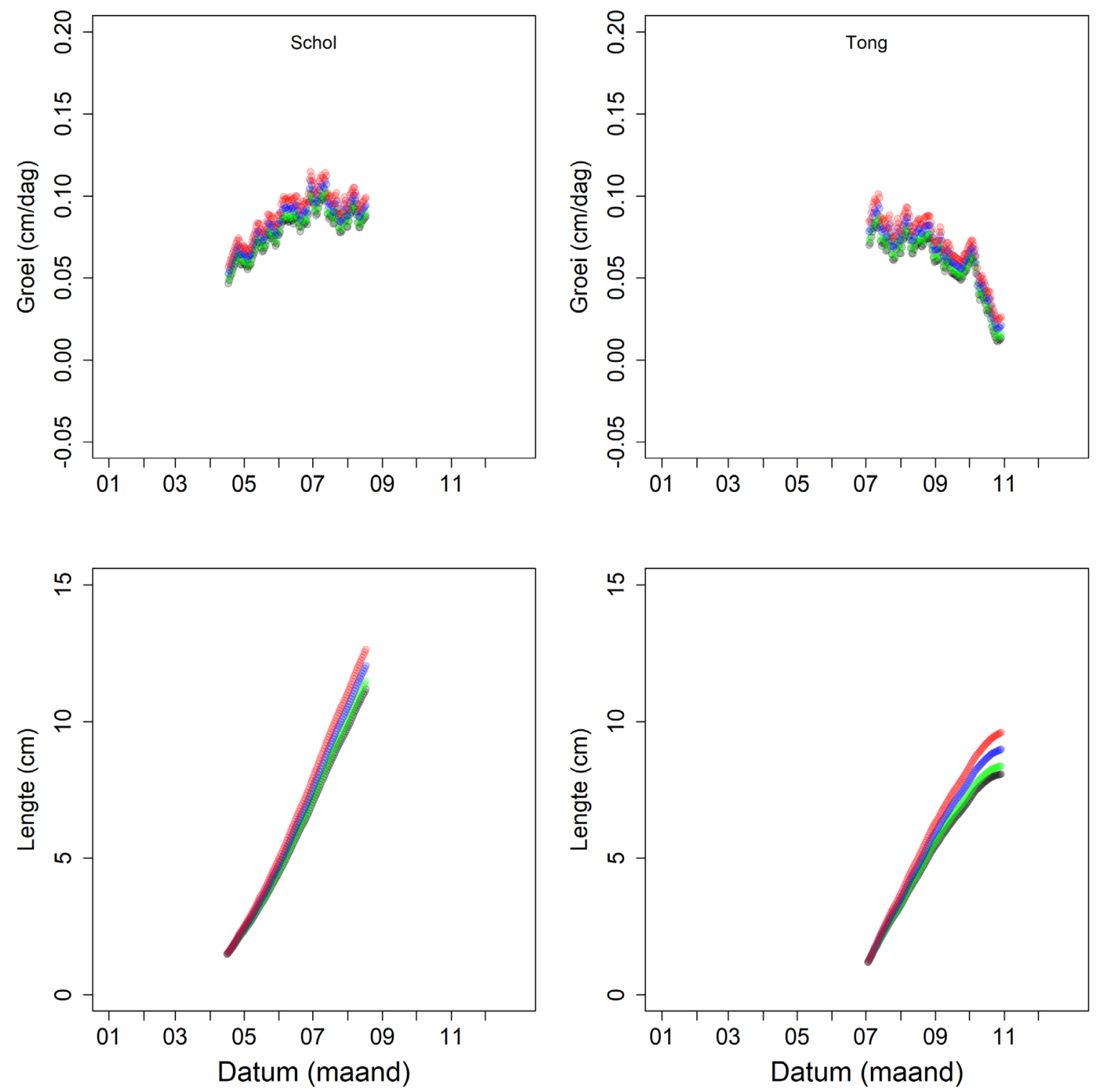

Figuur b 19 Groeipatronen voor schol (links) en tong (rechts) in 2011 (een koud jaar), Leeftijd 0, voor gemiddelden over alle locaties $<15$ meter gemiddelde diepte in 2005. De periode voor de groeiseizoenen en lengte aan het begin van de groeiseizoenen verschillen tussen de soorten (Tabel 7.1: Schol A0: 105-227, 16 april - 16 augustus; Tong A0: 183-300, 3 juli - 28 oktober). De groei wordt weergegeven voor verschillende klimaatscenario's, huidig (zwart): model; laag (groen): +0,01; hoog (blauw): $+0,03$ en extreem (rood): $+0,05^{\circ} \mathrm{C} / \mathrm{jaar}$. 


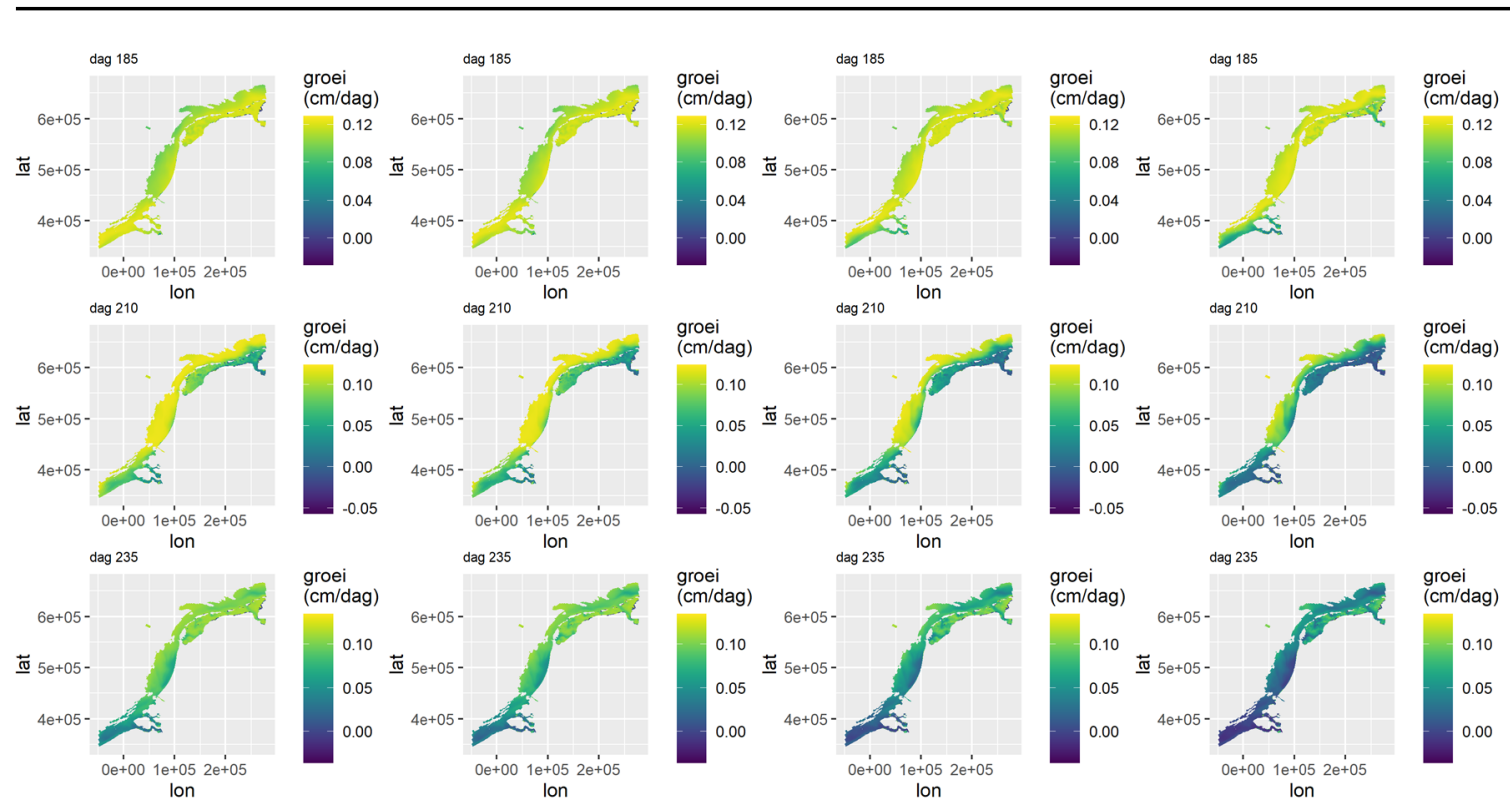

Figuur b 20 Groeicondities van schol AO (aankomst op dag X105, 16 april) in een "warm" jaar (2003) voor gebieden met een gemiddelde diepte $<25 \mathrm{~m}$. Uitgezet zijn de dagen 185 (5 juli), 210 (30 juli) en 235 (24 augustus).

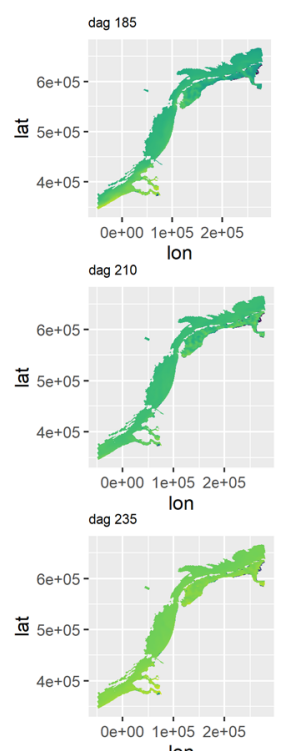

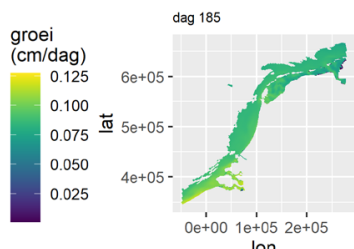
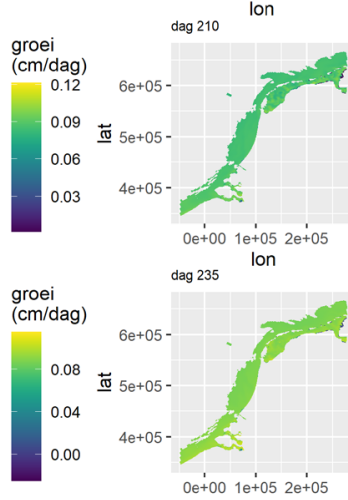

Ion

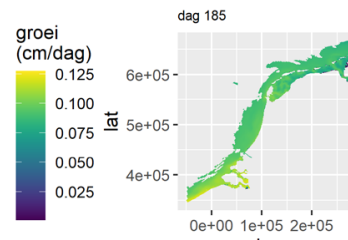

lon

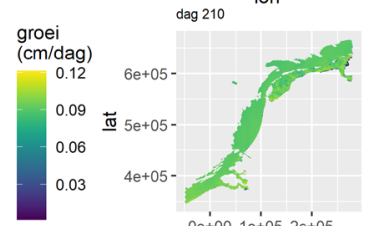

$0 e^{\prime}+00 \quad 1 e^{\prime}+052 e^{\prime}+05$

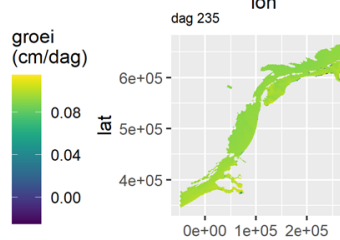

Ion

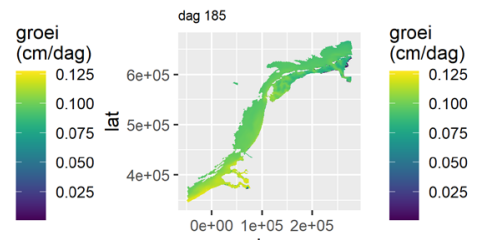

groei
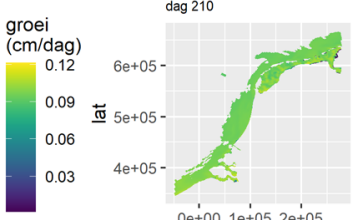

groei

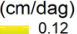

0.06

0.03

groei
(cm/dag)

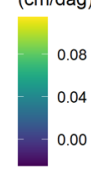

Ion

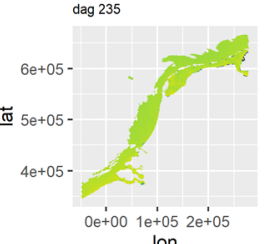

groei
$(\mathrm{cm} / \mathrm{dag})$

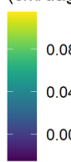

Figuur b 21 Groeicondities van schol AO (aankomst op dag X105, 16 april) in een "koud" jaar (2011) voor gebieden met een gemiddelde diepte <25 m. Uitgezet zijn de dagen X160 (10 juni), X185 (5 juli), X210 (30 juli) en X235 (24 augustus). 


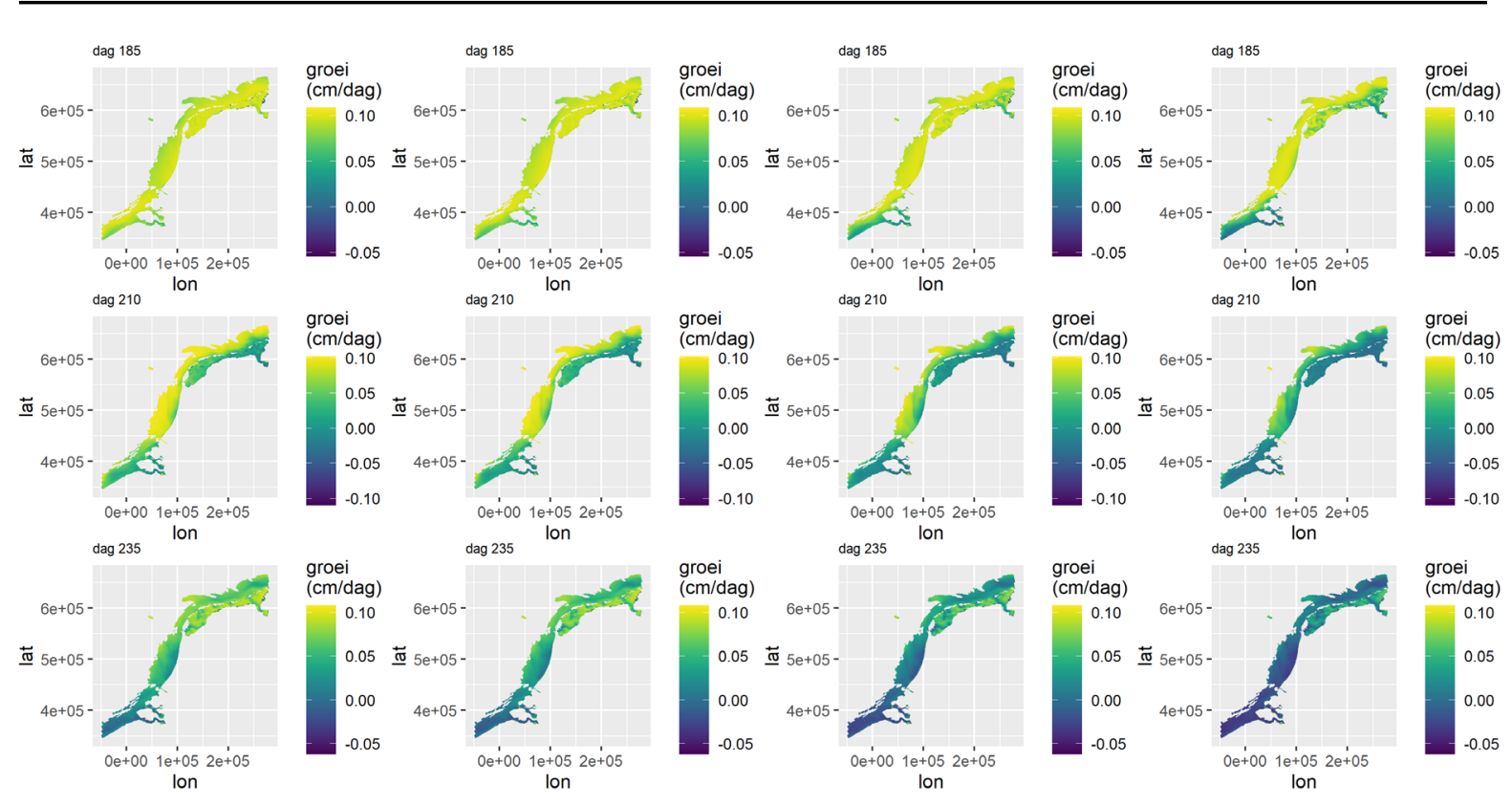

Figuur b 22 Groeicondities van schol A1 (aankomst op dag X120, 1 mei) in een "warm" jaar (2003) voor gebieden met een gemiddelde diepte $<25 \mathrm{~m}$. Uitgezet zijn de dagen X160 (10 juni), X185 (5 juli) en X210 (30 juli).

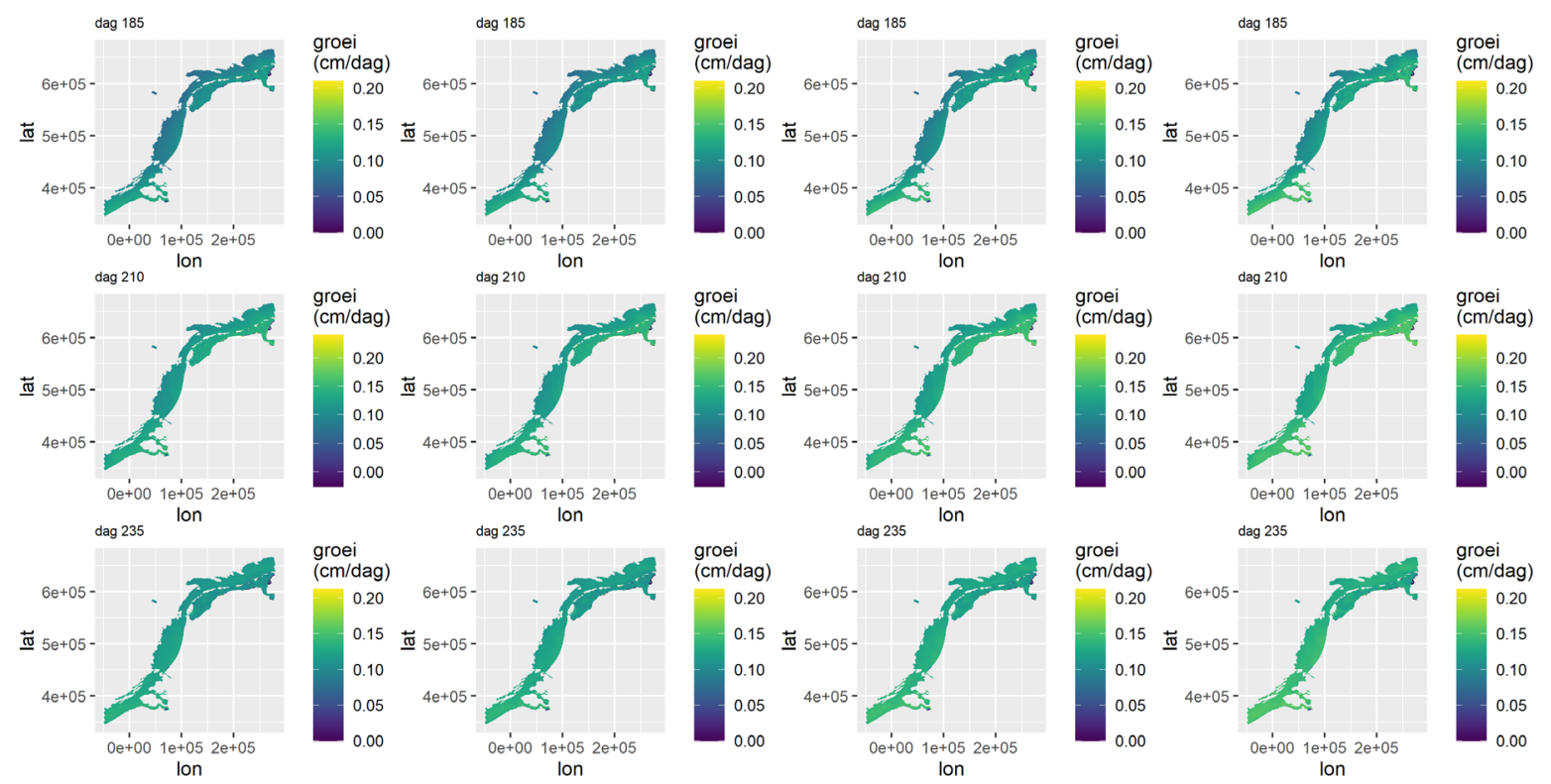

Figuur b 23 Groeicondities van tong AO (aankomst op dag X90, 1 april) in een "warm" jaar (2003) voor gebieden met een gemiddelde diepte $<25 \mathrm{~m}$. Uitgezet zijn de dagen X185 (5 juli), X210 (30 juli) en X235 (24 augustus). 


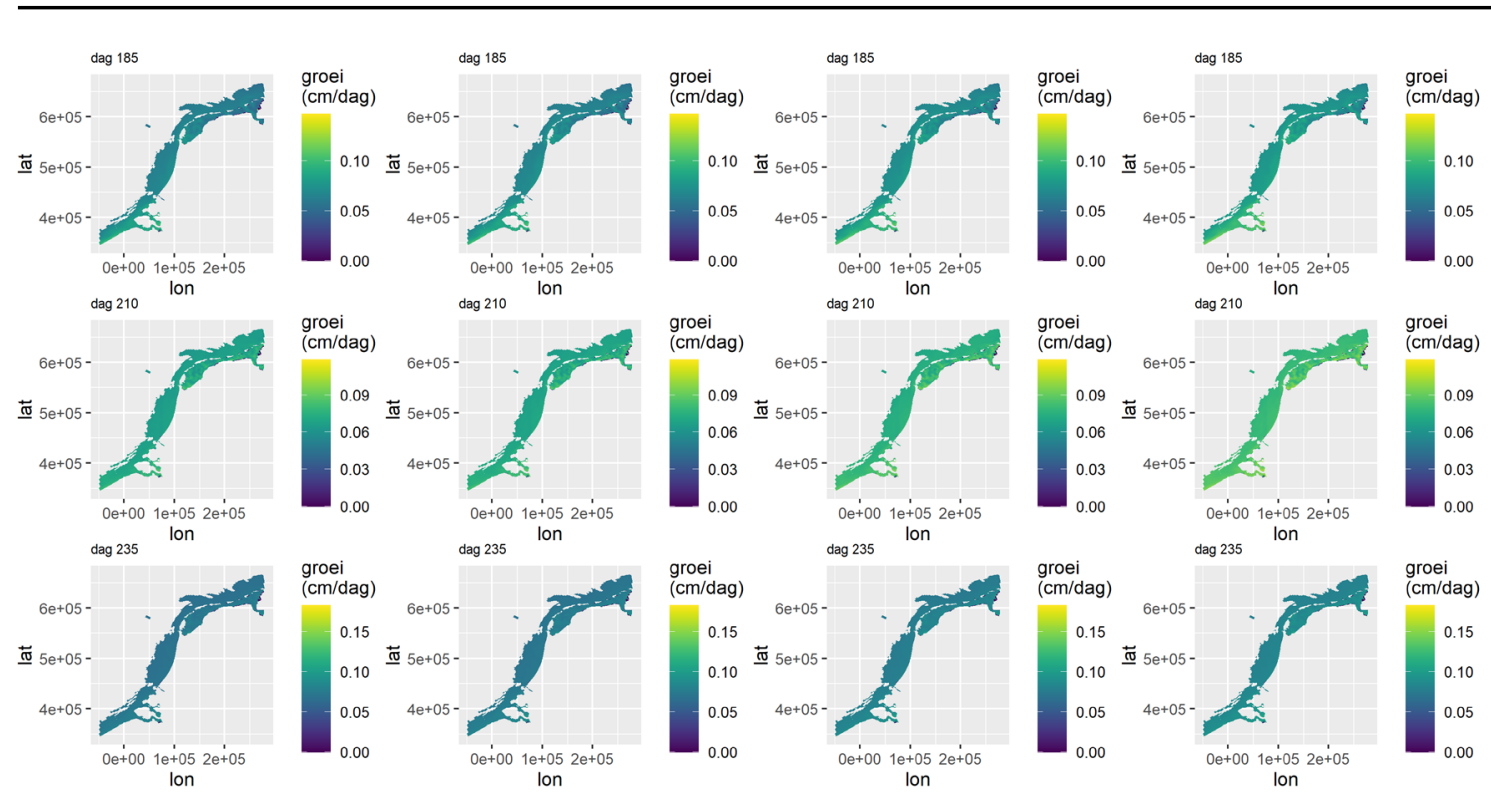

Figuur b 24 Groeicondities van tong AO (aankomst op dag X90, 1 april) in een "koud" jaar (2011) voor gebieden met een gemiddelde diepte $<25 \mathrm{~m}$. Uitgezet zijn de dagen X185 (5 juli), X210 (30 juli) en X235 (24 augustus).

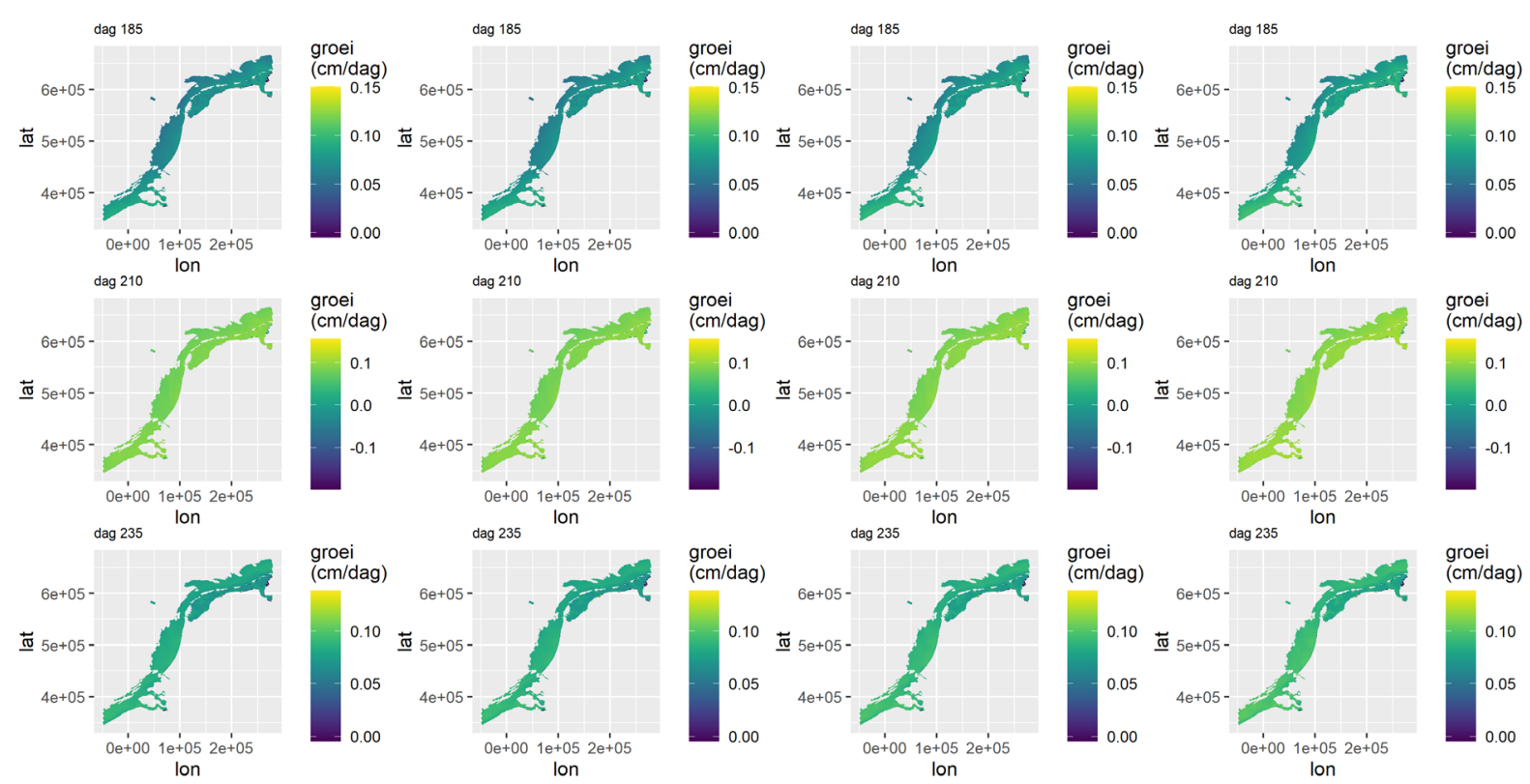

Figuur b 25 Groeicondities van tong A1 (aankomst op dag X120, 1 mei) in een "warm" jaar (2003) voor gebieden met een gemiddelde diepte $<25 \mathrm{~m}$. Uitgezet zijn de dagen X160 (10 juni), X185 (5 juli), X210 (30 juli) en X235 (24 augustus). 


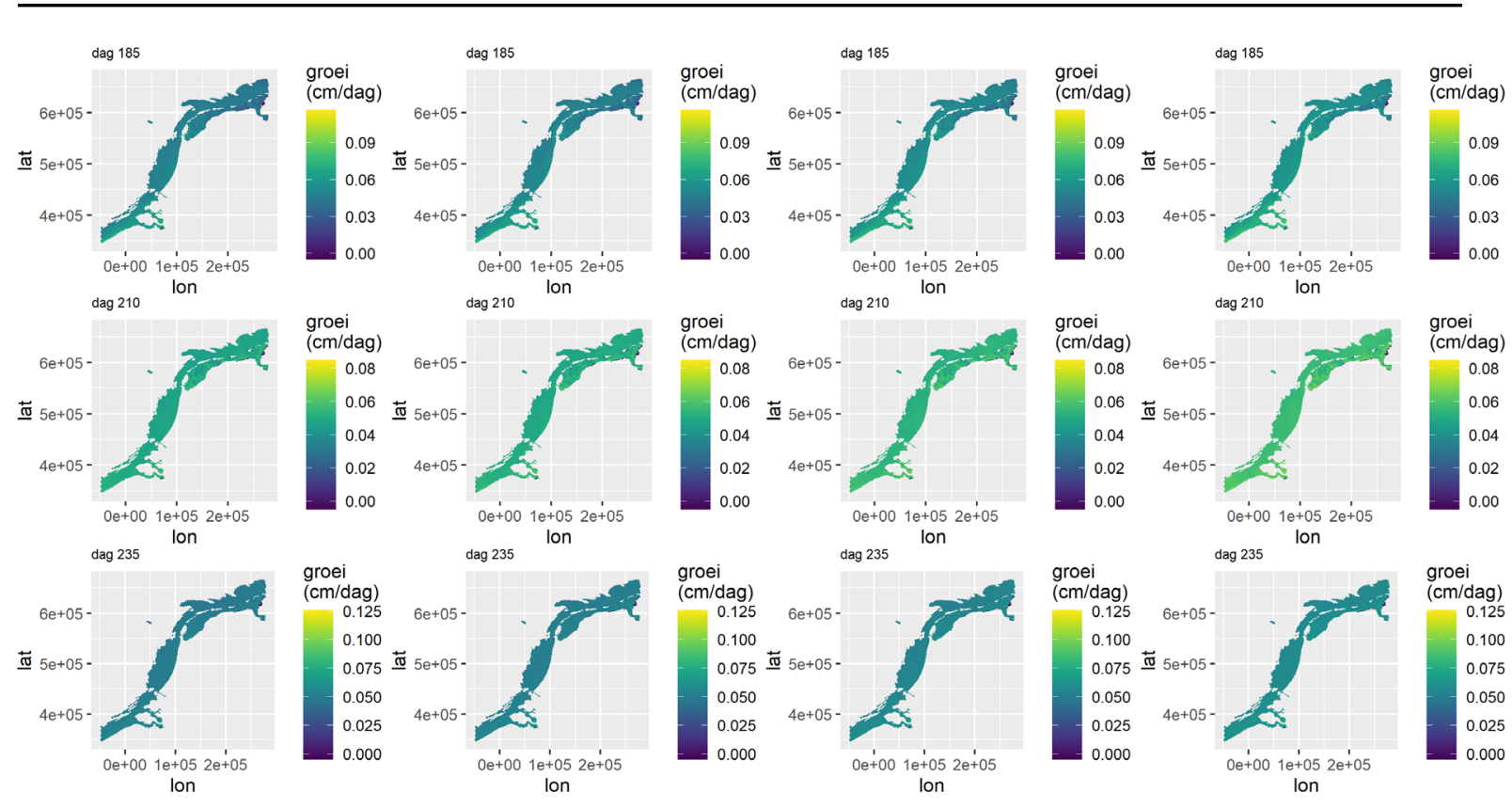

Figuur b 26 Groeicondities van tong A1 (aankomst op dag X120, 1 mei) in een "koud" jaar (2011) voor gebieden met een gemiddelde diepte $<25 \mathrm{~m}$. Uitgezet zijn de dagen X160 (10 juni), X185 (5 juli), X210 (30 juli) en X235 (24 augustus).
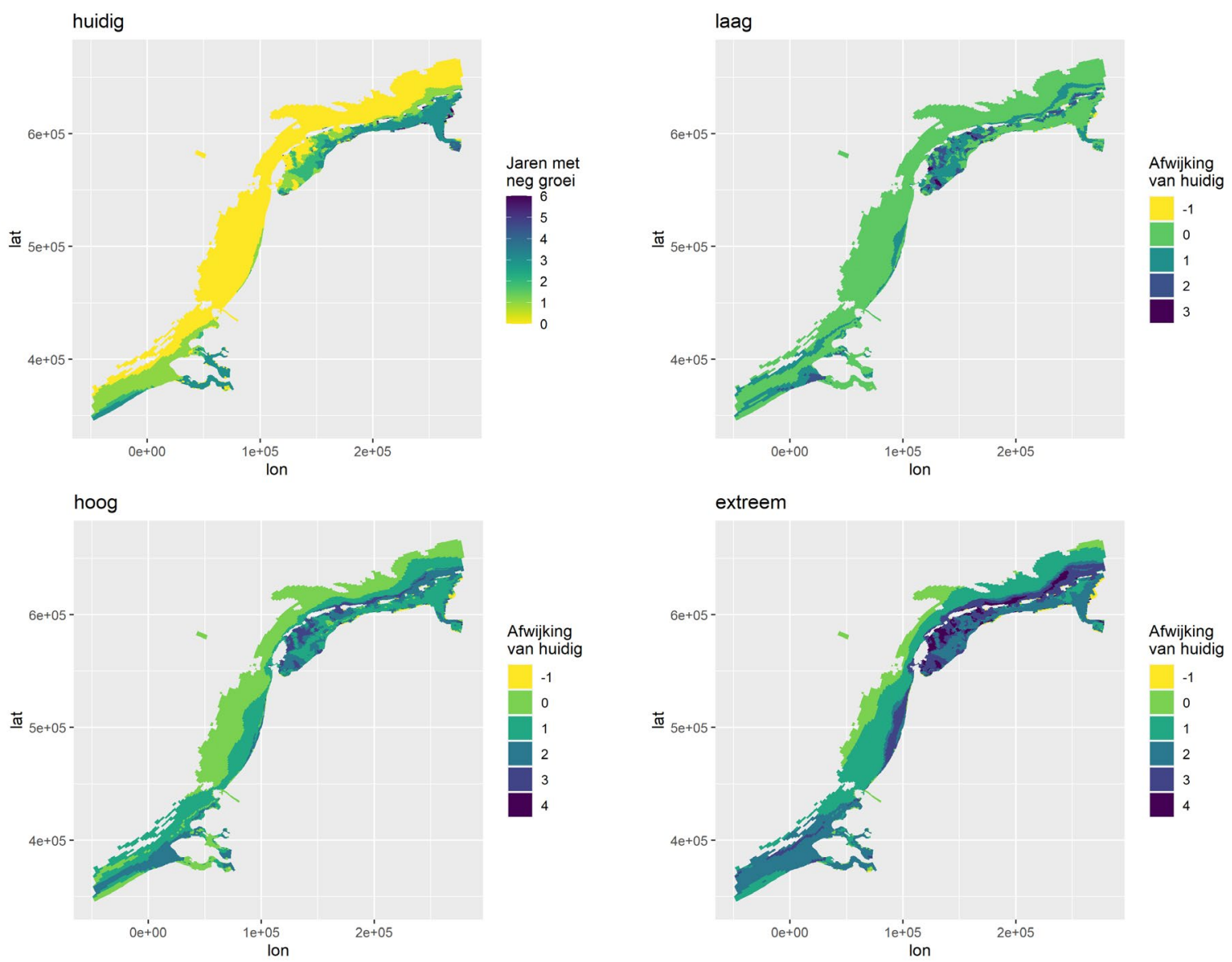

Figuur b 27 Aantal jaren met negatieve groeiomstandigheden in het groeiseizoen (Schol A1: 120 227, 1 mei -16 augustus) voor gebieden met een gemiddelde diepte $<25 \mathrm{~m}$. Het aantal jaren met negatieve groei in de data tussen 2003-2015 vergelijken we met de drie klimaatscenario's. Alle locaties die ondieper zijn dan $25 \mathrm{~m}$ in de dataset van 2003 worden weergegeven. 


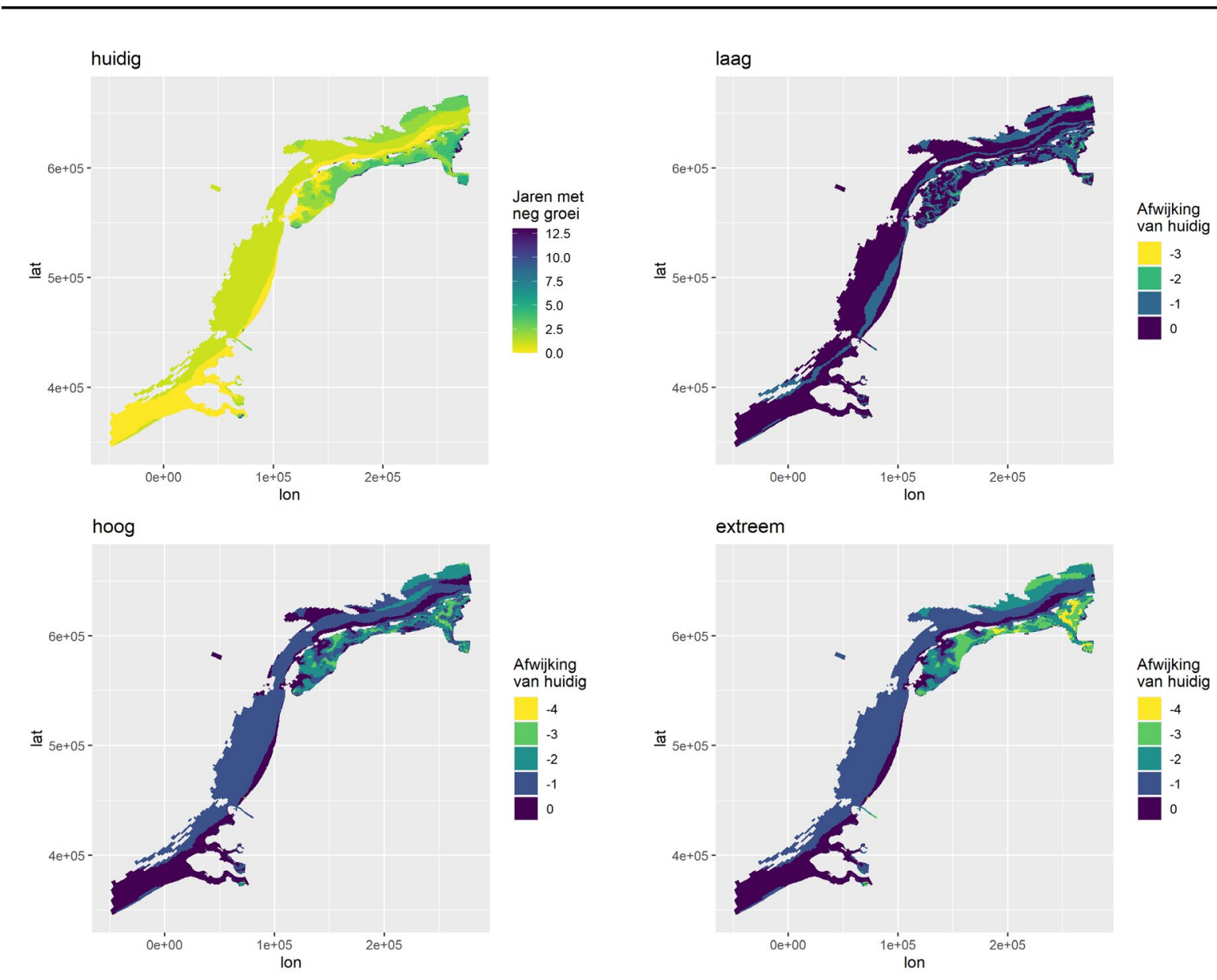

Figuur b 28 Aantal jaren met negatieve groeiomstandigheden in het groeiseizoen (Tong A1: 120-300, 1 mei - 28 oktober) voor gebieden met een gemiddelde diepte <25 m. Het aantal jaren met negatieve groei in de data tussen 2003-2015 vergelijken we met de drie klimaatscenario's. 

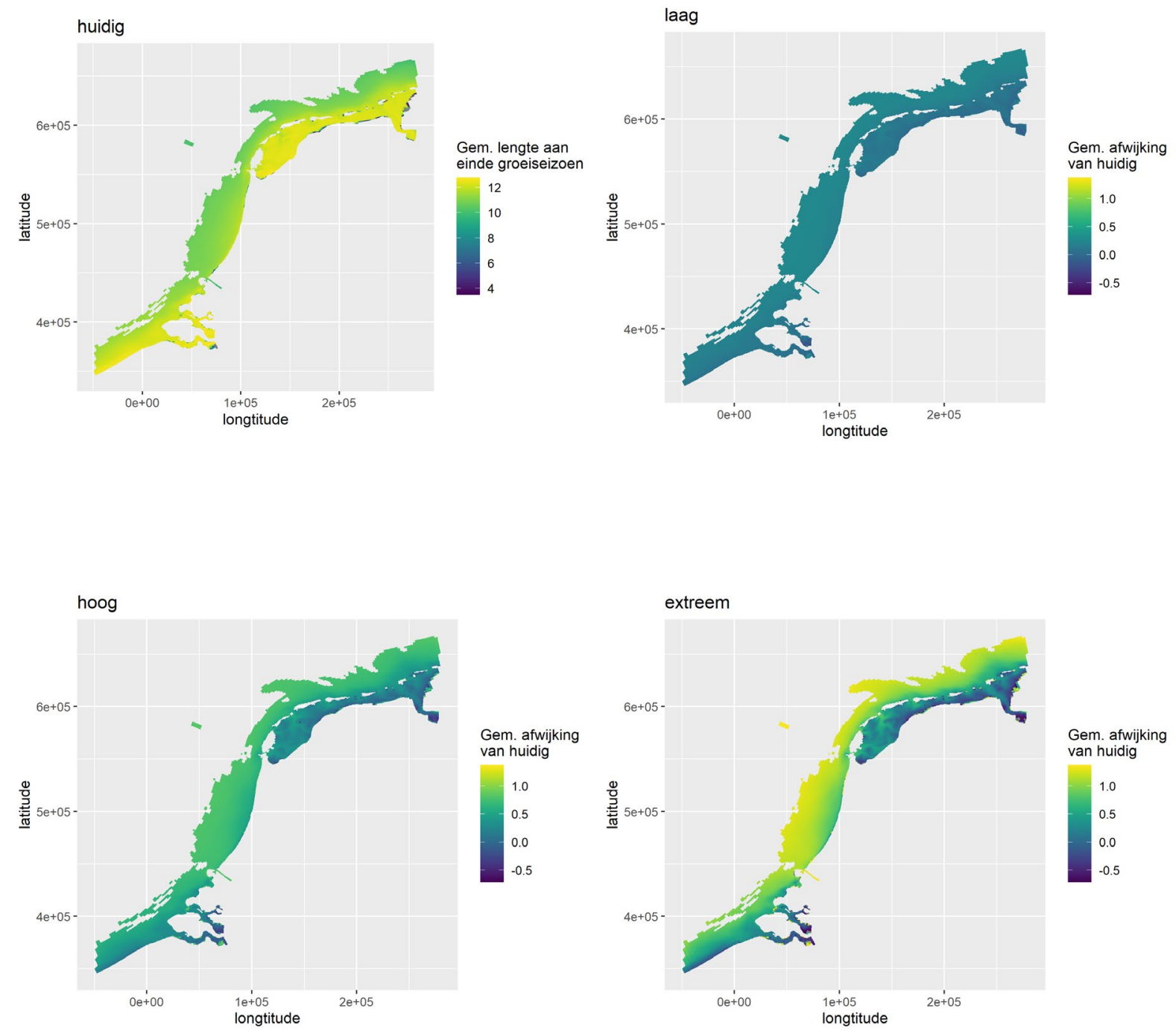

Figuur b 29 Gemiddelde lengte en gemiddelde afwijking van de normale lengte (in $\mathrm{cm}$ ) op de eerste dag van negatieve groei in het groeiseizoen voor schol AO (105-227, 16 april - 16 augustus) of, als er geen negatieve groei is, dag 227 (16 augustus). Gebieden met een gemiddelde diepte $<25 \mathrm{~m}$ worden getoond. 


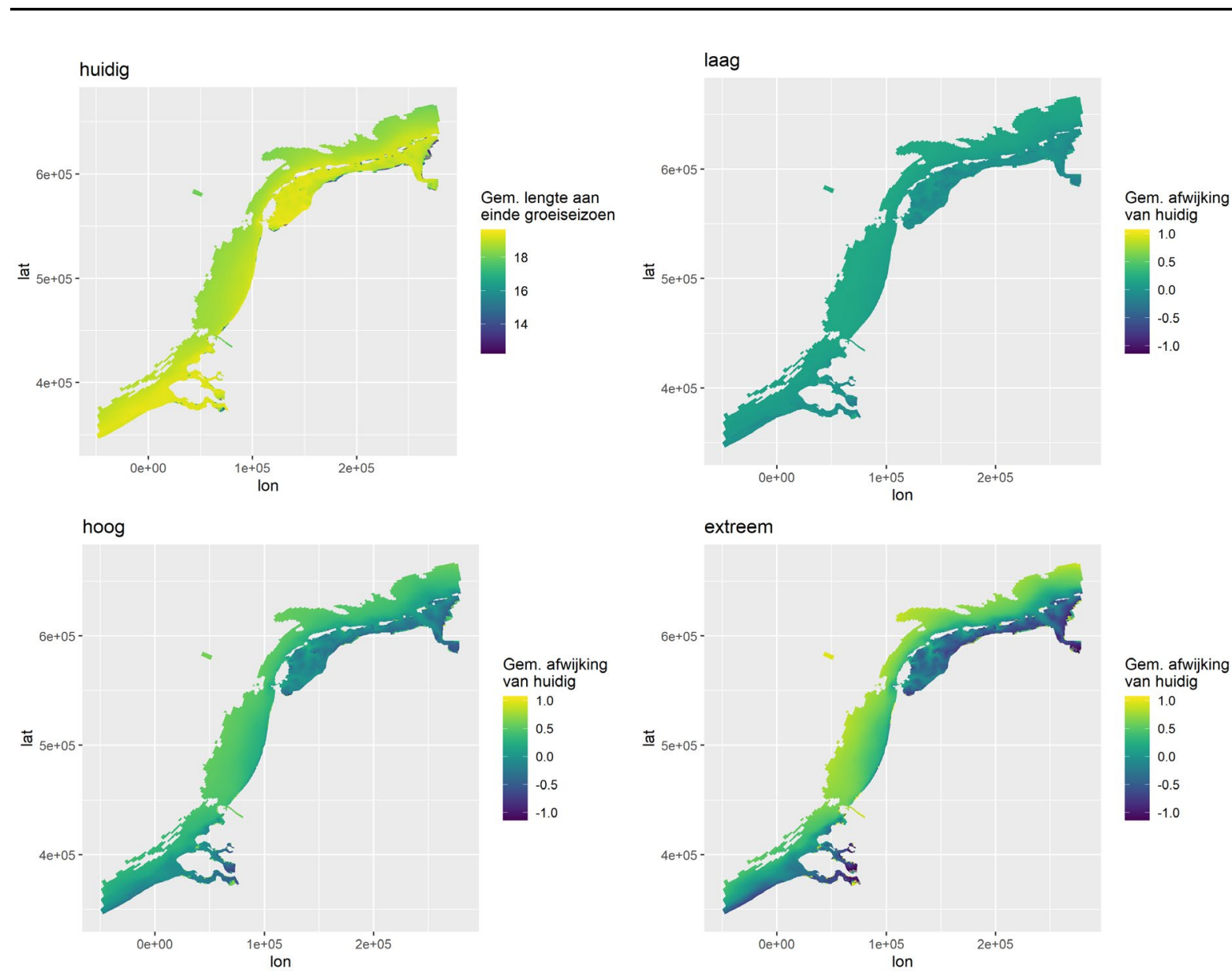

Figuur b 30 Gemiddelde lengte of gemiddelde afwijking van normaal (in cm, beide over jaren) op de eerste dag van negatieve groei in het groeiseizoen voor schol A1 (120-227, 1 mei - 16 augustus) of, als er geen negatieve groei is, dag 227 (16 augustus). Gebieden met een gemiddelde diepte $<25 \mathrm{~m}$ worden getoond. 


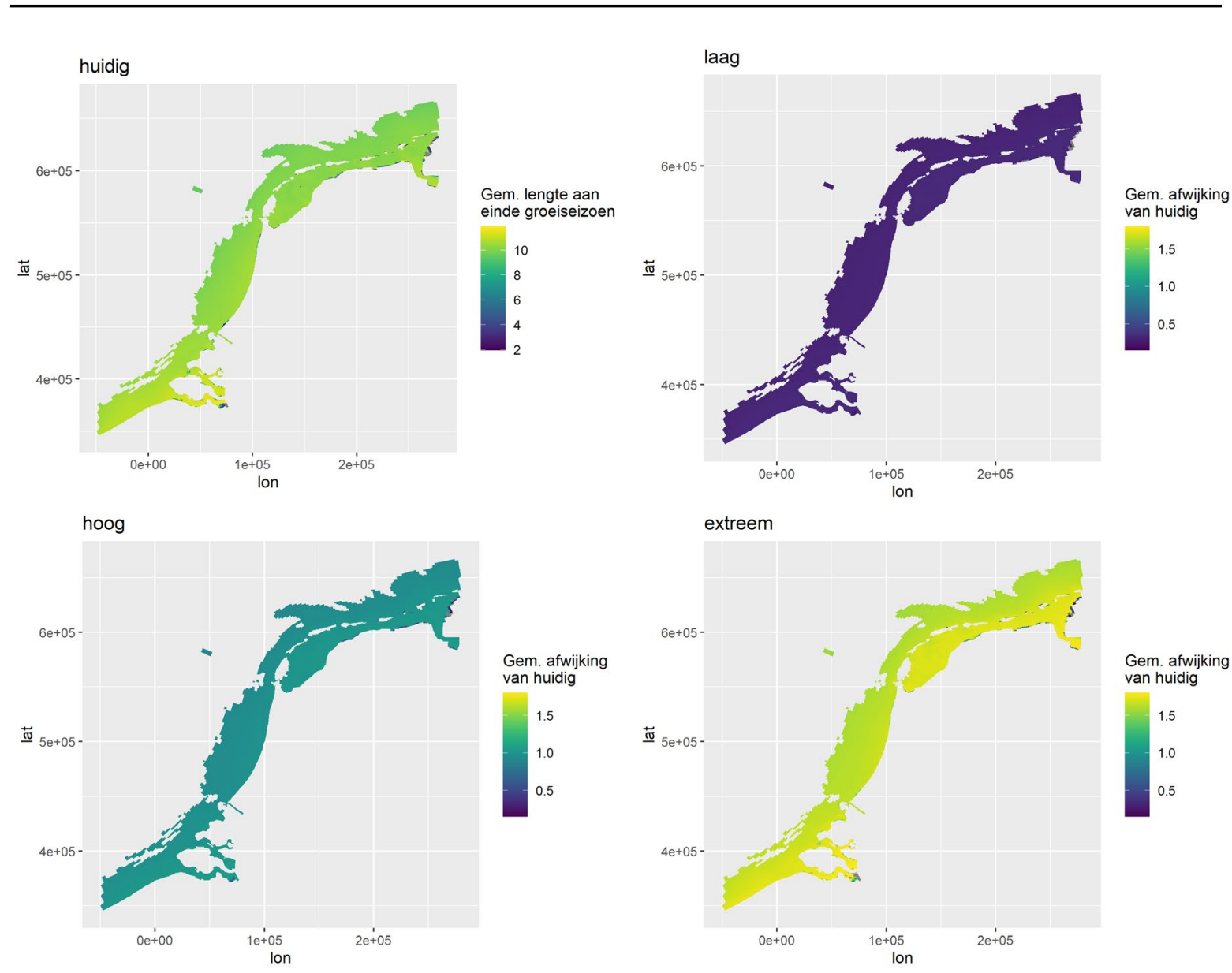

Figuur b 31 Gemiddelde lengte of gemiddelde afwijking van normaal (in cm, beide over jaren) op de eerste dag van negatieve groei in het groeiseizoen voor tong AO (groeiseizoen 183-300, 3 juli - 28 oktober). Als er geen negatieve groei is, wordt de lengte op de laatste dag van het groeiseizoen uitgezet. Gebieden met een gemiddelde diepte $<25 \mathrm{~m}$ worden getoond. 

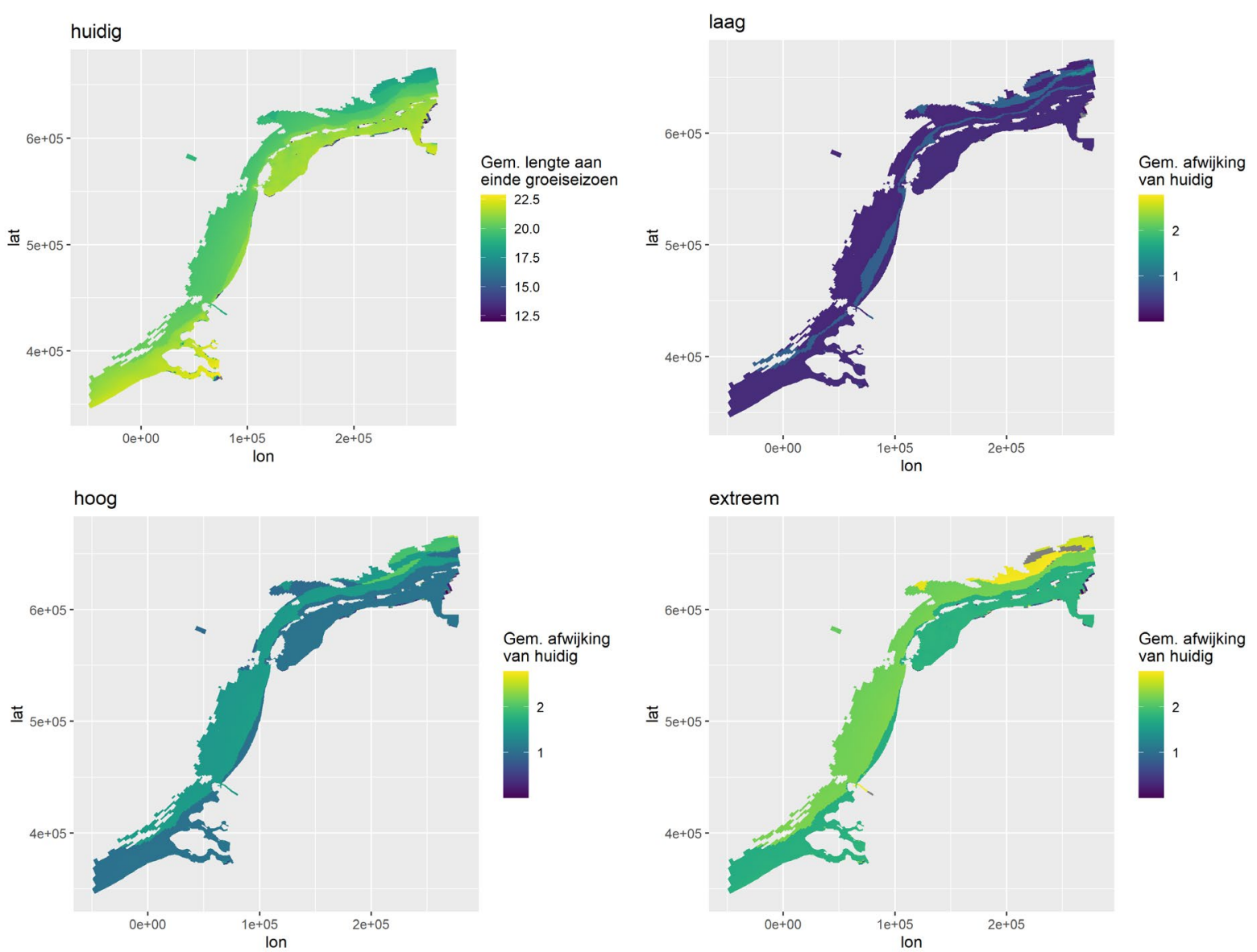

Figuur b 32 Gemiddelde lengte of gemiddelde afwijking van normaal (in cm, beide over jaren) op de eerste dag van negatieve groei in het groeiseizoen voor Tong A1 (120-300, 1 mei - 28 oktober) en de lengte op die dag. Als er geen negatieve groei is, wordt de lengte op de laatste dag van het groeiseizoen uitgezet. Gegevens over alle locaties die ondieper zijn dan $15 \mathrm{~m}$ in de dataset van 2003. 
Wageningen Marine Research

T: $+31(0) 317487000$

E: marine-research@wur.nl

www.wur.nl/marine-research

Bezoekers adres:

- Ankerpark 271781 AG Den Helder

- Korringaweg 7, 4401 NT Yerseke

- Haringkade 1, 1976 CP IJmuiden
Wageningen Marine Research levert met kennis, onafhankelijk wetenschappelijk onderzoek en advies een wezenlijke bijdrage aan een duurzamer, zorgvuldiger beheer, gebruik en bescherming van de natuurlijke rijkdommen in zee-, kust- en zoetwatergebieden.
Wageningen Marine Research is onderdeel van Wageningen University \& Research. Wageningen University \& Research is het samenwerkingsverband tussen Wageningen University en Stichting Wageningen Research en heeft als missie: 'To explore the potential of nature to improve the quality of life' 